Michal Reiman

\title{
About Russia, \\ Its Revolutions, \\ Its Development \\ and Its Present
}

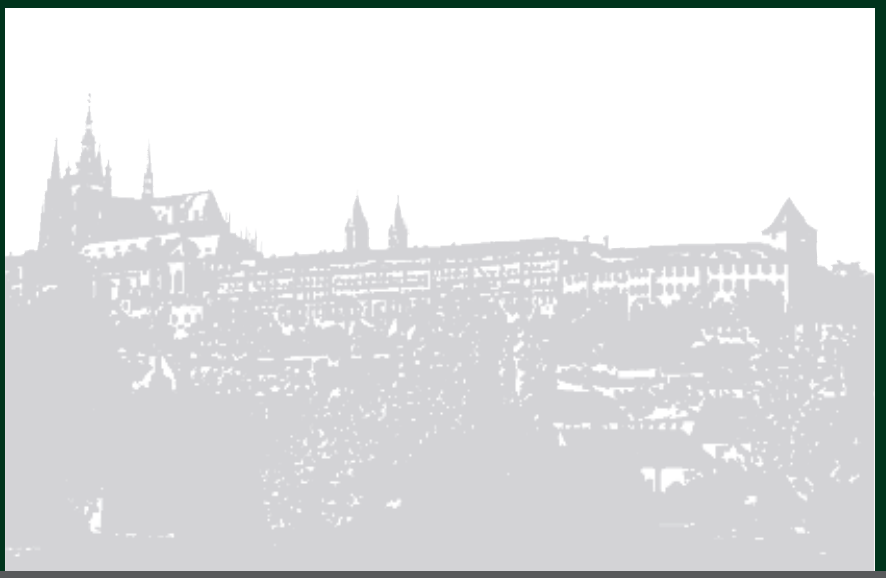




\section{Michal Reiman}

\section{About Russia, Its Revolutions, Its Development and Its Present}

The author analyzes modern Russian history from a new perspective. Due to the ideological heritage of the XIX and XX century, the social settings of the sociopolitical history of the USSR (1917-1945) have not been fully identified. Detailed examination of ideological and political concepts shows that the revolution of 1917 became not a middle class, proletarian movement, but rather a plebeian one. The misjudgment by the new power enabled growth but caused tremendous losses of human lives and material damages. Socialization of economy and strict centralization led to a new social structure and established terror as an instrument for social reorganization. WWII revealed the necessity of a correction of these developments, but the events of the Cold War circumvented any further considerations.

\section{The Author}

Michal Reiman lectured at the College of Political Science in Prague and was Professor at the Otto Suhr Institute of Political Science at Freie Universität Berlin and at the Institute for International Studies at Charles University Prague. 
About Russia, Its Revolutions, Its Development and Its Present 


\section{PRAGER SCHRIFTEN ZUR ZEITGESCHICHTE UND ZUM ZEITGESCHEHEN}

Herausgegeben von Michal Reiman,

Miroslav Kunštát und Jiří Vykoukal

BAND 10 
Michael Reiman

\section{About Russia, Its Revolutions, Its Development and Its Present}


Bibliographic Information published by the Deutsche Nationalbibliothek

The Deutsche Nationalbibliothek lists this publication in the Deutsche

Nationalbibliografie; detailed bibliographic data is available in the internet at http://dnb.d-nb.de.

An electronic version of this book is freely available, thanks to the support of libraries working with Knowledge Unlatched. KU is a collaborative initiative designed to make high quality books Open Access for the public good. More information about the initiative and links to the Open Access version can be found at www.knowledgeunlatched.org.

Open Access: The online version of this publication is published on www.peterlang.com and www.econstor.eu under the international Creative Commons License CC-BY-NC-ND 4.0. Learn more on how you can use and share this work: https://creativecommons.org/licenses/by-nc-nd/4.0/.

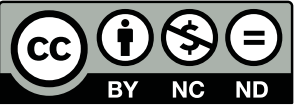

All versions of this work may contain content reproduced under license from third parties.

Permission to reproduce this third-party content must be obtained from these third-parties directly.

\section{Library of Congress Cataloging-in-Publication Data}

Names: Reiman, Michal, author.

Title: About Russia, its revolutions, its development and its present / Michal Reiman.

Description: Frankfurt am Main ; New York : Peter Lang Edition, [2016] |

Series: Prager Schriften zur Zeitgeschichte und zum Zeitgeschehen, ISSN

1861-163X; Band 10 | Includes bibliographical references and index.

Identifiers: LCCN 2016027098| ISBN 9783631671368 (print) | ISBN 9783653064735 (ebook)

Subjects: LCSH: Soviet Union-Politics and government-1917-1936. | Soviet Union-Politics and government-1936-1953. | Soviet Union-History-Revolution, 1917-1921-Influence. | Stalin, Joseph 1878-1953-Influence. | Soviet Union-Social conditions-1917-1945. | Revolutions-Social aspects-Soviet Union-History. | Social change--Soviet Union-History. | Social structure-Soviet Union-History.

| Political culture-Soviet Union-History. | State-sponsored terrorism-Social aspects-Soviet Union-History.

Classification: LCC DK268.4 .R45 2016 | DDC 947.084-dc23 LC record available at https://lccn.loc.gov/2016027098

The monograph has been published with the support of the Faculty of Social Sciences, Charles University in Prague, Research Development Schemes, programm P17 - Sciences of Society, Politics, and Media under the Challenge of the Times.

Reviewers:

Prof. a.D. Dr. Milan Průcha (Freie Universität Berlin) Prof. Dr. Dieter Segert (Universität Wien)

ISSN1861-163X

ISBN 978-3-631-67136-8 (Print)

E-ISBN 978-3-653-06473-5 (E-Book)

E-ISBN 978-3-631-69554-8 (EPUB)

E-ISBN 978-3-631-69555-5 (MOBI)

DOI 10.3726/978-3-653-06473-5

(C) Peter Lang $\mathrm{GmbH}$

Internationaler Verlag der Wissenschaften

Frankfurt am Main 2016

Peter Lang Edition is an Imprint of Peter Lang $\mathrm{GmbH}$.

Peter Lang - Frankfurt am Main · Bern · Bruxelles · New York ·

Oxford · Warszawa $\cdot$ Wien

This publication has been peer reviewed.

www.peterlang.com 


\section{Content}

Introduction

1. About the Russian Revolution of 1917 ....................................................13

The Russia’s Maturity Level ............................................................................13

The Russian Revolution of 1917 and Its Causes.

Russian Marxism and the Bolshevics as a Political Party..............................15

The Russian Revolution as a Plebeian Revolution...........................................18

2. The "Building Socialism" in the early 1920s.......................................25

The War Communism and the NEP ..............................................................25

The Events of 1923 in Germany and the Origin of the "Left

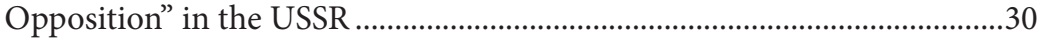

The Party and the Opposition after Lenin.........................................................36

The Opposition and the NEP ..............................................................................39

3. The NEP Crisis and Suppressing of the Left Opposition.................49

The Year 1925 and Crush of Soviet Industrial Planing ..................................49

Tautening International Relations and the NEP Crisis....................................52

The Party and Opposition in 1927. The "Platform" of Opposition...............55

4. The Stalin's "second" Revolution....................................................................61

The 1928 Crisis and Stalin's Conflict with the Party "Rightists" ...................61

Stalin, his First Five-Year Plan and Related Issues ..........................................70

Collectivisation of Agriculture and Its Consequences....................................74

The 1932-1933 Famine and Changes in Stalin's Politics ...............................79

5. Stalin's "Soft Course" and the Soviet 1930s Phenomenon...............85

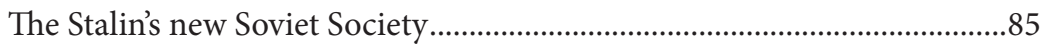

Kirov's Murder and the Turning Point in Stalin's Domestic Policy..............91 
Changes in the International Situation and Soviet Politics..........................95

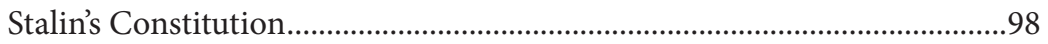

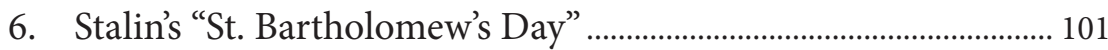

7. Consequences of Mass Massacre of the Soviet Elites..................... 113

The Country after the Mass Massacre of Elites............................................. 113

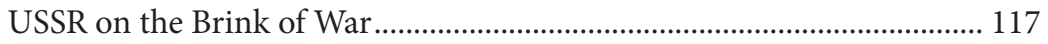

8. The USSR in the Second World War, 1941-1945 .......................... 121

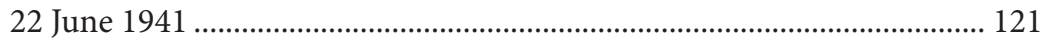

Consolidation of the Soviet Leadership and Command ........................... 125

The 1943 - Turning Point of the War............................................................ 128

Stalingrad and Kursk ................................................................................... 133

9. The USSR and Western Allies.............................................................. 137

Connection and contradiction of the Allies................................................... 137

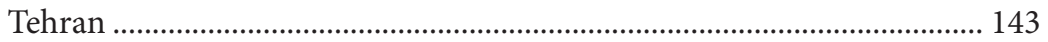

10. The USSR and East-Central Europe ................................................... 149

The USSR at the Countries of East Central Europe and Balkan on the End of War ............................................................................................... 149

Churchill, Stalin and the "Percentage Agreement" .................................... 158

Yalta and Potsdam ...................................................................................... 163

11. The USSR as the New World Superpower........................................... 169

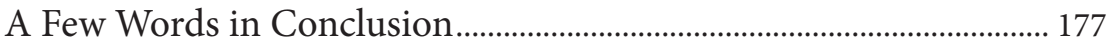

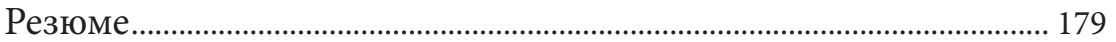

Bibliography............................................................................................ 183

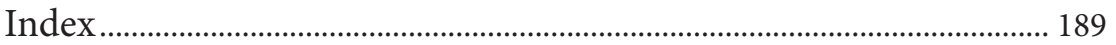




\section{Introduction}

Although a scattering of memoirs and other literature emerged during the period between the wars, it was in the 1950s that the pace of international research into the history of the Soviet Union visibly hastened. Its course was serpentine, with a scope of investigation that reached well beyond the dictatorial, later totalitarian, turn taken by the political powers when Russia's traditional government and social system collapsed in 1917. State and social structures, the economy, personal relationships, science and culture - the elements which a country's national life is constructed of - were placed upon fresh foundations in Soviet Russia and the USSR. International relationships, as well, were drawn a new. Accordingly, those who would research these events must take deeper notice of political history and the decisions of the governing powers than they otherwise might.

Indeed, the progress of the research has itself suggested the course of Soviet political history. In recent decades, Soviet history in general, and the country's political history in particular, have seen a clash of ideological and political concepts. Key in this was the watertight censorship of the Soviet regime, which condemned Soviet historians to parrot officially approved historical schemas. Another factor was the Cold War atmosphere that insinuated itself into research and influenced the ideology and politics of social science content both in the East and, in a different guise, in Western Europe and the United States.

Today, the archives have been unsealed and censorship controls relaxed in Russia and the USSR successor states, and historiographical research has attained to a new standard. Previously unknown sources have surfaced to redefine our views of Soviet history. Their interpretation has been enhanced by the contributions of Russian and Russian-speaking historians, who, freed of their fetters, have lent valuable insight into the nuances of Russian and Soviet ideology, psychology, and the country's way of life.

But these newly emerged sources are marked by internal tensions and substantive conflicts that stem from the diverging views held immediately after World War II by Western researchers, on the one hand, and leftists, European communists and Soviet historians on the other. The former were influenced by the concept of totalitarianism, which equated the Soviet system to that of Germany in the grip of the Nazis. In the 1917 revolution and the USSR's subsequent development, the latter, by contrast, saw the construction of a socialist society. This view of Soviet historiography did not initially change even once the excesses of the Stalin era had been revealed. The disclosures did cause a number of historiographical 
tenets to be challenged; but heavy censorship was brought to bear, dissent was squelched, and essential information was kept classified. And so, Soviet historians of the era remained blocked from venturing into new directions of research.

When the Twentieth Congress of the Communist Party of the Soviet Union took place in 1956, it was Western sources of research that were chiefly impacted by its outcome. In the United States, and later in Europe, studies challenging the dominance of the totalitarianism concept appeared with growing frequency. This was especially true in the work of the American 'revisionists', soon to be supported by European scholars as well. They conducted meticulous studies of social and sociocultural elements, and performed detailed analyses of the facts of Soviet development.

By the early 1960s, the official portrayal of Soviet history had eroded to the point that its loss of status was felt in the USSR itself, as well as in the countries of the Soviet bloc and among Western left-wing theorists and communists. The attempt to deal critically with the reality of the Soviet system that lay beneath the shift in outlook, particularly Stalin and Stalinism, formed the thrust of an emerging stream of dissent, and figured prominently in the writings of post-Stalin émigrés. The dissenters lacked internal homogeneity. Some bought into the notion of totalitarianism with which they had become acquainted. But the left flank, for political and factual reasons, took a different tack. On a number of points, it approximated the ideas on Soviet history of the Western revisionists. During the 1980s, it was the totalitarianism concept, alongside various offshoots of Russian and other nationalist ideologies, which gradually gained ground among Soviet dissenters and Soviet émigrés.

Before it could secure its position, however, the 1991 collapse of the USSR took place, making Soviet archive materials available. Historiography in the USSR assumed a new form and acquired a new focus. Most former taboos gave way, and a wide-ranging exchange of opinions among historians from the former USSR and the West sprang up. A kind of revolution in historiography had been sparked. Research into the history of the USSR was internalized, and a process of assimilating international currents of thought got underway. But the historiography of the individual nations and state systems of the former USSR, including that of the Russians, was also strongly influenced by nationalist ideology. It took holding the course of the countries' own efforts to justify their frequently incipient existence as nations and states, and was concurrently reflected in international research.

Our objective in this book will not be to evaluate the outcome of this historiographical development - even more so since it is far from complete. Our own 
sympathies lie with those concepts and methodologies that approach their subject differentially, assessing the multifaceted impact and significance of events.

The research that has been carried out in both the West and in the former USSR has focused, above all, on Stalinism - its origin and development, its causes and consequences. Crucially, this research has understated the degree to which the historical picture was distorted by Cold War elements whose roots, in many cases, reach deeper down than the developments after World War II. Indeed, they reflect many ideological and political schemas already in existence prior to World War I, as expressions of the rifts and conflicts between the imperial powers in Russia and the Central European states, particularly Germany. This is worth highlighting, because once the Cold War had ended, these could have served as starting points for the development of 'novel 'ideologies, which might have justified the long-standing antagonisms between the Western world and the European East, and perhaps other regions as well.

The history of Russia after 1945 is beyond the scope of this work. Present-day Russia is not a totalitarian state. This is despite the fact that it is plagued by abiding problems that cannot be remedied by simply trying out Western political and social patterns. For reasons which merit targeted, independent research, Russia's development in the pre-Soviet period substantially lagged that of the leading European countries - Great Britain, France, and Germany -as well as that of the USA. After 1917, its developmental potential was severely checked in turn by the collapse in World War I, the Stalinist terror and the consequences of Stalinism, and the heavy losses incurred in the war with Nazi Germany. The latter took a toll of 25-29 million lives, with a material and cultural loss impossible to quantify even today. Russia lost several generations of its elite. But while it is true that the Bolsheviks had overestimated their chances of boosting the living standard in the USSR to catch up with the developed world, even this is no alibi for the country's backwardness, which concealed its weak points and hid its deficiencies.

In reality, the rise of Russia was never contingent simply upon political will. The mere adoption of Western patterns could not bring it about. What was needed was something attained neither easily nor quickly: a far-reaching, nationwide effort. Attempts to speed changes in Russia's standard of living usually saw existing levels of economic and social progress in Russia and the USSR exaggerated in an ultimately unhealthy effort to maintain superpower status. The development that took place on this basis did nothing to ease the friction between Eastern and Western Europe, or to blunt the threat of mutual alienation between them.

The pages to follow treat the history of Russia from 1917 until 1945. This period contains, in concentrated form, the negative aspects that have attended the 
country's evolution in the present era, and that have generated frequent discussion about the extent to which Russia is a part of Europe. In fact, the country's role in the political and cultural history of the continent has been considerable, and this should not be forgotten. Thesis also true with respect to the Europe of the twentieth-century, influenced as it was by Russian leaders such as Lenin, Stalin, and Trotsky, who made a lasting mark on the course of European history and European political thinking. As historians, we must eschew anything that might obscure the ties between Russia and Europe and unwillingly fuel their mutual alienation - with potentially fatal consequences for both.

We are not speaking here solely about ideological constructs that express the diminished significance of the world role played by Europe and European civilization, in the process reducing that role even further. The tendentious, imprecise way twentieth-century researchers retold the events of Soviet and European history gave rise to many conceptualizations and ideological schemas that influenced research into individual issues, some of key importance. Today, large numbers of Soviet sources are being published and scrutinized. But frequently, they bear the marks of the outdated Soviet and European perceptions of history that stem from prior decades. Even though the sources themselves may be bona fide historiographical or, in academic in another discipline, they burden the discipline with the weight of outmoded stereotypes.

To us today, Stalin's attempt to reshape society by violence and mass terror seems to have posed a much greater danger than some historians of the 1970s and 1980s perceived in it; ${ }^{1}$ freshly declassified materials show that the regime's brutality went enormously beyond what most earlier literature had supposed. ${ }^{2}$ But even with what has come to light about Stalin, the fact remains that the USSR cannot be force-fitted into a one-size-fits-all, internally homogeneous concept of totalitarianism that encompasses both Stalinism and Nazism.

We discuss here the historical classification of terror and the role it plays, as well as the use of the term 'totalitarianism' in Soviet history. The Stalinist terror

1 Litvin A./ Keep J., Stalinism: Russian and Western views at the turn of the Millenium, London / New York, Rouledge/ Taylor \& Francis Group, 2005; see also Voráček E., Stalinismus a Sovětský Svaz 1927-1939. Historiografie, evoluce výzkumu, problém výkladu fenoménu a jeho interpretační modely, in: Litera B. a kol., Formování stalinského mocenského systému:K problematice tzv. sebedestrukce bolševiků 1928-1939, Prague, HIU ČAV, 2003.

2 This is clear in, e.g., Wert Nicolas, La Terreur et le Déssarroi:Staline et son systeme, Khlevniuk O, Chozjajin:Stalin i utverzhennye stalinskoy diktatury, Moscow, ROSSPEN 2010 . 
was a complex historical phenomenon. It was not a direct descendent of the terror of the revolution or the civil war, even if this period did leave a significant mark. Instead, it was in the post-revolutionary phase of Lenin's rule, separated from the 1930s though it was by the NEP period, that the Stalinist terror found its roots, transmitted by the same generation, still in power. The terror was motivated by a fundamental crisis the Soviet system suffered in the late 1920s and early 1930s. Market inequalities brought about deep differences in the character and tempo of agricultural versus industrial development, as well as in what was required for that development to take place. It was thus from sources other than those that had motivated the terror of the revolution and the civil war that the terror of the 1930s sprang.

Special attention must be given to the "Great Purge" of 1934-38 that arose out of the aforementioned crisis. In 1937-38, this mass terror, directed against social elites and holders of post-revolutionary power, resulted in the arrest of 1.5 million citizens by the NKVD, according to official figures. The actual numbers were undoubtedly much higher. Of these victims, 700,000 were executed. ${ }^{3}$ This extended instance of terror was unique from its outset in mostly targeting entire social strata instead of specific individuals, adversaries, or opponents of the regime. The victims hailed from groups reluctant, for one reason or another, to accept the plans and decisions of the governing party. The impact of the repression was felt as well in social relationships, where it functioned to forcibly reshape social life. Many of the means used were justified as essential for the 'construction of socialism. ${ }^{4}$ During Stalin's reign, as during Lenin's, show trials were held of 'counterrevolutionaries' and 'saboteurs'. These repugnant performances were offered to explain away failed governmental projects and mistakes made during the economic and social reconstruction process. The 700,000 people we have noted were executed during this two-year period starting in 1937 - half of those jailed - received no judicial

3 Reabilitatsiya: Kak eto bylo.Dokumenty Priezidiuma CK KPSS i drugiye matierialy, eds. A. N. Jakovliev, Volume 1, Moscow, MFD, 2000, pp. 76-77, tab. 15; official data from 1954. The term "terror" in the proper sense of the word, however, includes not only mass arrests, imprisonment, and the murder of citizens. It also includes a policy of intimidation whose goal was to attain certain social or other objectives. This is important to note, because its restricted use may easily cause a distortion of historical reality.

4 Reiman, Michal: Lenin, Stalin, Gorbachev:Kontinuität und Brüche in der sowjetischen Geschichte, Hamburg, Junius, 1987, 140-142; Stalin's notes on the topic the following during the $16^{\text {th }}$ Congress of VKS/b (1930): "Repressions in the Course of Socialist Construction Are a Necessary Element for an Offensive”. See Stalin, Sochineniya, Volume 12, p. 309. 
hearing of any kind. This aspect of the Great Purge will be discussed in the main text. These victims differed from those who suffered under Stalin's restructuring of the economy and society by being ensnared in a systematic effort to massacre the post-revolutionary Soviet political, social, and cultural elite.

What is written here is based upon a monograph I co-authored, entitled Genesis of a Superpower: The History of the USSR 1917-1945. The goal in that publication was to explore the depiction of the USSR during the period referenced in the title by historians of the past. In addition to the crucial issues of the era, it investigated specific facts which had been left out of historiographies from both the East and the West, and whose omission derived from political or ideological motivations, or otherwise stemmed from inadequate research or a biased point of view. The present text offers the content and conclusions of that work in a briefer form.

I would like to thank Doz. Dr. Jiří Vykoukal for reviewing the text. 


\section{About the Russian Revolution of $\mathbf{1 9 1 7}$}

\section{The Russia's Maturity Level}

Traditional concepts of Russian history, still current in historiography today, point to the Emancipation Reform of 1861, which abolished serfdom, as the start of a half-century of economic, social, and political change. This reform, however, was not the consequence of a peasant groundswell; rather, it arose from Russia's humiliating defeat in the Crimean War of 1853-1856. The war laid bare the developmental chasm that existed between Russia and countries such as Britain and France. It was apparent in the economy, in transportation, and in the military. But it was especially obvious in the realm of education, culture, and social life.

The substance of the defeat the country had suffered was overshadowed soon enough by fresh events. These included the Austro-Prussian War of 1866, which significantly weakened Austria, and the Franco-Prussian War of 1870-1871. The latter had curtailed the might of France, in the process clearing the way for Prussia to create the modern German Empire. An entirely new constellation of powers thus came into being, characterized by the signal rise of the Germans, and temporarily obscuring the drop in power and influence of Russia. This loss of standing was soon reflected in Russia's catastrophic defeat in its war with Japan (19041905) and in a sharp loss of influence in Europe, particularly in the Balkans.

As Dietrich Geyer noted, in a monograph on Russian imperialism excellent for its time, the freedom accorded Russian peasants was far from adequate to allow for the modernization of Russian life. ${ }^{5}$ It was not just that the Emancipation Reform had not gone far enough; other requisites for the development of a modern market economy and society were also missing. These included a stable, convertible currency; a balanced state budget; a mature banking network; opportunities for loans; an adequate legal basis to establish a market economy; willingness on the part of the populace to adopt a new lifestyle and play an active role in the market; a developed railway system; water transport; and other factors. But what took place in Russia in the latter half of the nineteenth and the early twentieth century's did not represent the birth of a market economy. Rather, it involved the transition from a system in which serfdom and aristocracy were

5 Geyer Dietrich, Der Russische Imperialismus:Studien über der Zusammenhang von innerer und auswertiger Politik (Göttingen, Vandenhoeck a. Ruprecht, 1977). 
bound as intimately as communicating vessels to one dominated by a multisector economy. Over time, market relationships gradually gained in strength and reach, but they still failed to permit the progress toward modernization vital for the formation of the economy, and for the social and educational organization of the populace. This was testified to by low population numbers and social segmentation inadequate for a modern society. The populace also lacked political experience and organization. Meantime, Russia's share in the global economy was vanishingly small compared to that of the other superpowers of the time: the USA, England, Germany, France, and the Austro-Hungarian Empire. The logical conclusion would seem to be that the essential components of a modern society had failed to develop in Russia pre-1917. But this can only be confirmed by further research, for these requisites were partially in place in the leading cities of St. Petersburg and Moscow, as well as in the towns of central Russia, the central Volga watershed, the Urals, Kiev, Kharkov, and Odessa. This still left seventy to eighty percent of the population wanting for adequate development.

It is in this context that we must approach Lenin's thesis on Russia's ripeness for a socialist revolution, a concept which was featured prominently in communist and left-wing literature in the twentieth century, and which came under a great deal of criticism. Lenin founded his maturity thesis upon primarily political arguments, setting to one side the niceties of social issues and the economy. Originally, he invoked a 'lack of revolutionary spirit' on the part of the Russian bourgeoisie, which would enable an alliance to form between peasants and the proletariat and lead to a 'dictatorship of the proletariat' and to 'building socialism'. But Trotsky likely had the greater portion of the truth. He noted that disparities between the interests of workers and peasants would allow them to rule jointly only with the support of victorious revolutions in developed countriesthe potential for whose occurrence he grossly overestimated. In practice, Lenin's concept suppressed the political independence of the peasantry from the outset. ${ }^{6}$

His notion of the worker, one fully embraced by Soviet historiography, warrants close scrutiny. Available data shows that the number of industrial workers in pre-revolutionary Russia was well under ten million, and during the 1920 civil war this figure dropped even more precipitously-according to Trotsky's estimate, to seven- or eight-hundred thousand. ${ }^{7}$ Before the revolution, most

6 This particularly refers to suppressing peasant soviets and peasant organizations after November 1917, unequal voting rights for peasants, etc.

7 Information indicated by Trotsky at the IXth Congress of RKP/b (Stenograficheskiy otchet, Moscow. Gospolitizdat, 1960, s. 93). 
industrial workers had maintained strong ties to the countryside, and were socially positioned midway between the factory and the field. The last batch to come streamed into the cities just before World War I as a result of the Stolypin's reforms. ${ }^{8}$ There was already an undeniable presence of industrial workers in large industrial and urban centres such as St. Petersburg, Moscow, Donbas, and Baku. But many in the urban lower echelon might be better classed as urban plebeians: in addition to the industrial workforce, unskilled and seasonal workers, craftsmen, the business and transport rank-and-file and minor intellectuals also played a major role. During the First World War, the stratum was reinforced by the presence of soldiers in garrison towns, navy men and women, and the young men who had replaced the soldiers in some industrial works. Many of these people were partially illiterate, some entirely so, and their understanding of politics was minimal. When we speak about this lower stratum of city dwellers as a significant force in the Russian Revolution of 1917, we must understand them as plebeians, and the revolution as a plebeian revolution, without intending the label pejoratively.

\section{The Russian Revolution of 1917 and Its Causes. Russian Marxism and the Bolshevics as a Political Party}

Investigations into the immediate causes of the 1917 revolution in the older literature were strongly coloured by the political and ideological exigencies of the time. There is no doubt today that the revolution ignited spontaneously from the tinder of grudges held by soldiers and workers in St. Petersburg, joined by those of other towns and regions, by the Baltic Navy, and later, by soldiers on the front lines. Despite this reality, Soviet historians portrayed the revolution as the wellplanned outcome of Bolshevik policy, allowing spontaneity only a minor role. Even liberal and left-wing historiography that was not outright Bolshevik, and that emphasized the spontaneity of the revolutionary outburst itself, attributed its subsequent radicalization to Bolshevik actions. Some pointed to the Germans and 'German' money supplied to the Bolsheviks. ${ }^{9}$ Conservative Russian historians implicated the Freemasons-a code word for liberal politicians inside and

8 Bonwetsch B., Die russische Revolution 1917: Eine Sozialgeschichte von der Bauernbefreiung 1861 bis zum Oktoberumsturz, Darmstadt, Wissenschaftliche Buchgesellschaft, 1991, pp. 71-79.

9 Regardless of the fact that this was said to relate chiefly to the Czarina and her circle during the war. 
outside the Duma - and attributed the revolution and its radicalization to external politics hostile to 'Russia'.

These interpretations are challenged when one explores the events of the time in greater depth. As noted, government policy gave rise to the grudges of workers and soldiers that served as the flashpoint for the revolution; so did the despotic attitude of the owners of Putilov, St. Petersburg's largest machine works, and the shortage of bread in the stores of the city's working-class districts. Even here though there is room for greater precision. In addition to the aforementioned causes, the unsuccessful conduct of the war had sapped the country's capacity. By 1917, a major segment of Russian society knew that Russia had already lost the war, and that even a potential victory by the Allies would not bring the promised profit nor see Russia restored to its pre-war geographic extent. Since there was no point in continuing to fight, Russians became convinced that only the rapid conclusion of an armistice and peace would save the country from catastrophe. This gives some insight into why the Russian provisional government resisted separate peace negotiations with Germany. The Allies rejected peace with Germany and the Triple Alliance on any basis other than the latter's defeat. The provisional government could not cope with this attitude, but by deciding to respect it in the end, it lost the chance to significantly influence domestic political events. ${ }^{10}$

These facts are not entirely decisive for assessing the nature of the Russian Revolution. Russia was a country, as we have noted, which lacked an economic and social structure adequate for establishing an industrialized society. Nor, on the same basis, could a political democracy based upon civil freedoms take root. The revolution did not ameliorate this situation; indeed it exacerbated it in many respects, particularly when it came to the standard of living and respect for civil rights. From the Marxist standpoint, even in its Russian incarnation, this meant long-term priority for tasks the Russian Marxists had defined even before the revolution as 'bourgeois democratic'. Socialism became a realistic goal only once prerequisites were set in place to overcome capitalism 'at the level of the social productivity of work. The wait for these prerequisites to be met, as we now know, stretched to more than a century. 'Socialist concepts' could and did influence the manner and methods by which problems were resolved in Russia. But they could not in any principled way change their content. The radicalization of the revolution and the Bolsheviks' seizing of power did not alter the basic tasks the country

10 However, it may be claimed that the policy exercised by the Allied powers did not allow for any other option. 
had to resolve; rather, the result was a faulty assessment of economic and social reality and the opportunities for initiating change. ${ }^{11}$

This is key in understanding the events of 1917. The March revolution was not the starting point of a bourgeois revolution that 'expanded into' a socialist revolution, as Soviet ideology held. It was instead a confluence of civil and plebeian revolutions whose guiding ideas determined the developmental level of the economy, the education of citizens and the social relations between them. These two revolutionary streams were separated by the fact that different social strata had formulated their goals, and by the variant ideas and methods to be used in meeting them.

Because Russian capitalism and its social structures were inadequately developed, the civil stream came into the revolution relatively weak. Its social and political base was narrow and its national composition fragmented. Its impact was made chiefly at the level of cities and national regions, and only to a minor extent beyond those borders. From the very outset, the plebeian stream of the revolution was broader-based and more radical than the civil stream. Its members, as noted, were workers, or were drawn from the amorphous lower classes of the cities, or from the ranks of soldiers in the city garrisons, or of sailors serving in the navy. The movement was clustered around city soviets, and was characterized by the radicalism it demanded of members, a radicalism which cared less and less for the current state of things in the country. It was also distinguished by the blurred focus and short-lived nature of its interests. The interests expressed by members from the lower strata of the cities differed stridently from those of the village, and this was reflected in the structure of the soviets. There were worker and soldier soviets, and there were famer soviets. Two centres came into being, each independent, each spanning the country. These two centres had originally been able to collaborate because each had a strong presence of moderate socialists willing to work with liberals. Support for them grew out of the initial mood of the soldiers and minor urban intellectuals.

The radical stream comprised Bolsheviks, albeit not exclusively. They strove to anchor their influence with the industrial workforce and urban plebeians. In St. Petersburg, they also sought out sailors working for the Baltic navy and soldiers in garrison units. They were distinguished from the moderate socialists by their opposition to the war, with which they could make no headway in an alliance with the liberals, or with Russia's war allies, as has been discussed. The

11 We are setting aside the question of whether "socialism" as understood by Russian Marxists and, in particular, by the Bolsheviks, was attainable. 
moderate socialists were therefore unable to distance themselves from the liberals' war policy, causing their defeat in the soviets and in the revolution itself.

In autumn of 1917, after a failed attempt of a military coup by Lavr G. Kornilov aimed at suppressing the revolution in the key centre of St. Petersburg, the civil revolution was overtaken by a plebeian revolution. The government was now headed by a new segment of society, one that did not understand the prospects or capabilities of the revolution, that totally lacked experience, and had no knowledge or factual qualifications needed to conduct a war or manage the country. Its power was solidified by its brutality, by the mass terror it employed against opponents, real or imagined, by the zeal with which it cast off the burden of war even at the cost of losing it, and dismantled the old, now disintegrated army. It was shored as well by removing the explosive peasant issue. The government began forthwith to divide farms, no matter its impact on crops or the food production market, and to persecute the wealthier peasants-the 'Kulaks'. It also sidestepped the national issue by allowing, or at least not blocking, the origin of new national states within the former empire. This loosened prior restrictions and allowed the country to take shape as a single, pan-national power and to win the civil war over its opponents, whose power lay strictly in the border regions of the state.

But the Russian revolution cannot be discussed simply in terms of the processes and events which led to it. Beyond having brought a socialist party to powerhowever we may evaluate its brand of 'socialism'-it is also noteworthy for being the first revolution to take place in a backward country far removed from having the social and educational structure of an industrial society. In hindsight, the discussion of 'bourgeois' versus 'socialist' society in that era and later was timeless. It obscured the real substance of the thing: a new type of revolution had been born that was typical for underdeveloped countries where the prerequisites for a modern civil society were lacking. It was in countries such as these that the disparity between development and lack of development, between the developed world and the underdeveloped world, was worked on, and this proved to be defining for a pivotal century.

\section{The Russian Revolution as a Plebeian Revolution}

The victory of the plebeian revolution in Russia in 1917 brought no change to the long-term tasks the country had before it, but it did usher in radical transformations to the social environment, and to the ideology and methods used to carry out these tasks. Russia's ties to the external world also changed radically, as did relationships within areas of the country. Its Western part, home to 30 million 
people with a European orientation-Russian Poland, the Baltics and Finlandwere lost. St. Petersburg, both the product and the source of Russian Europeanization, was deprived of its role as an administrative and cultural centre. The majority of the country's centre of power and culture was distanced from Europe both socially and in how people thought about it, and in terms of space and transportation, as well. For their part, the newly created states on the western border of Russia had no interest in maintaining Soviet Russia’s influence, now threatening to their existence in the free European space. This reinforced the provincial background, traditional culture, and impact of lifestyle of Russia's Asian population. Further barriers sprang up, to rapid economic development and modernization that later, in the late 1920s and early 1930s, were behind an acute state of crisis in the Soviet system.

Changes to social power were crucial, and for making it impossible to create a political and social system like those of the West, civic politicians held the Bolsheviks to blame. But the roots of the divide were in fact well in place prior to November 1917. They lay in the weakness and immaturity of the civic society, as attested to by those powers' defeat in the civil war, which could not be forestalled even with support from the Allies. Long before decisions about the civil war had to be made, most recognized civic politicians had fled the country. It thus remains uncertain whether the outcome would have differed had the Bolsheviks' opponents won the war. That the regime that did arise was authoritarian was not an exclusively Russian matter; it stemmed as well from the lack of stability of a long line of successor states to Russia, the Austro-Hungarian Empire, and Germany, in the east, the centre, and the south of Europe.

The Bolsheviks themselves were originally aware that Russia was underdeveloped, an awareness that formed the basis for Zinoviev, Kamenev, Rykov and other Bolshevik representatives to take a stand against an exclusively Bolshevik government and strive instead for a coalition of socialist parties in November 1917. Lenin also noted the 'bourgeois content' of the revolution at the Eighth Bolshevik Congress in discussing measures taken by the post-revolution Soviet government, ${ }^{12}$ and the subject also came up in a number of statements he made in 1921 justifying the need for introducing the NEP. ${ }^{13}$

His thinking on the issue was not impromptu. It was built upon the preceding course of the Russian revolutionary movement, which formulated its objectives

12 Vos'moj sjezd RKP/b: Protokols. Moscow., Gospolitizdat, 1959, pp. 20-21.

13 The abbreviation for the New Economic Policy, justifying the need for market relationships within the Soviet Union. 
in terms of Marxist ideology without regard to the country's underdevelopment. From its very start in the late nineteenth and early twentieth centuries, this brand of Marxism deviated substantially from the European version. First came Lenin's statement claiming capitalism as the basis of the Russian economy,${ }^{14}$ thereby opening the opportunity to paint specific events and phenomena caused by the country's lack of development as characteristic manifestations of capitalism. In the West, Marxists maintained that all the capitalist development options needed to be exhausted before socialism could take hold. It could not do so within a single country, they believed, but only after the majority of developed capitalist countries had ascended to a new developmental level. In Russia's case, Lenin was satisfied with finding that capitalism, or the 'market', had become the predominant component in the economy, taking that as proof of the country's maturity.

European socialists believed that before a worker government could take power, workers must become the dominant component of society. But in Russia, the social base was too narrow to accommodate this concept of worker government. As of March 1917, the Bolsheviks had approximately 40,000 members and insisted on the party's selectivity ${ }^{15}$ and their concept of a party was a de facto national concept that saw in the party an association of 'the chosen'. Lenin emphasized the position of the intelligentsia, assigning it the role of creator and bearer of socialist ideas he denied workers. ${ }^{16}$ The party concept was crowned by the notion of 'democratic centralism, a principle which placed the 'bearers of socialism' in a hierarchy which subordinated lower bodies to higher bodies, and which bound those lower bodies to fulfil unconditionally the dictates of the higher. A hierarchy of positions and people is a factor in most political parties. But its Bolshevik conception guaranteed no room for democratic party decision-making. Many decisions were strictly subject to secrecy, often even from party members, and not always in connection with illegal goings-on. Then there was the conflict noted between ideology and social reality. This became a pervasive element in Bolshevik thinking, leaving attempts to resolve particular social situations short of means. Paradoxically, the

14 Here we refer especially to Lenin's work The Development of Capitalism in Russia, dating to the late $19^{\text {th }}$ century.

15 They could not maintain this concept in 1917. Statistically, the party grew by a multiple of five that year, with about 200,000 members.

16 We intend here Lenin's “What Is To Be Done?" and his "Where To Begin?" from the early $20^{\text {th }}$ century. Lenin stated that workers by their own effort may create only "trade union consciousness", while the intelligentsia is charged with creating and introducing a socialist consciousness into the workers' movement. 
Bolsheviks produced a socialist vision without creating socialist relationships in daily practice.

Let us examine in this context the special characteristics of the social structures that grew out of the Bolshevik revolution. They were typical for Russia as well as for other underdeveloped countries that took the Russian revolution as their model. In all these cases, power was seized by members of the poorly structured lower strata of society. The army and its officer corps played an active role in some of these revolutions, which is an important exception. The corps had its own structure built on organizational experience and discipline, unidirectional though it was, that was transferred to the social structure. At the highest ranks were usually revolutionaries and functionaries, and revolutionary organizations. These people did not necessarily belong to the lower social strata but, as their predecessors in revolutionary Russia had, they lacked the knowledge and experience needed to resolve social and factual issues to do with governance. ${ }^{17}$

A negative of the Russian development was that those few members from the country's educated class were excluded from participation on a mass basis, left with only an 'auxiliary role' instead of being able to take part in running the state, cities and towns as economic and social leaders. Only a handful was spared, 'experts' and artists willing to heed the party's notion of how they should proceed professionally and creatively. Even at that, the party engineered poorer conditions for their accommodation, their supplies, and their personal safety. It subjected them to despotic rule at both the central and local levels, restricted the space available for their artistic or scientific work, and frequently limited the education of younger members of their families. All told, this drastically curtailed the influence of the educated in the Soviet state after 1917.

The new source of power relied instead upon plebeian society, which had little structure. This translated into a power base that was adequately broad but wanted for structure and was therefore ill-prepared to govern. Under such conditions, the vertical layers of Russian society were based not on assets or knowledge, but mostly on power. They evolved based on a hierarchy of authority, economic and social functions whose structural skeleton was the highly decentralized, often militarized state system. That reliance upon the plebeian strata was preferred strongly marked the political culture. No social customs, no culture of governance inherited was taken into account; that inheritance had derived in any event

17 We are setting aside the special case of revolutions influenced by religious considerations, typical for the second half of the $20^{\text {th }}$ century and for Islamic countries. There, social and political solutions are tied to religious concepts and have a different developmental framework than do revolutions following from Russian examples. 
from an autocratic state. Instead, there was a tendency to violent solutions and the dictates of power. Developed countries shunned collaboration with the governing powers in resolving economic, social, and cultural issues.

If we speak specifically of Soviet Russia and the social patterns to which it gave rise, we discover the vertical stratification of society was based almost entirely on the positions of individuals and groups within the power structure, that is, on their positions in public administration. Key in this was the ranking of party functions. The party stood over all other entities and organizations in the Soviet state, and in this respect, it was in its very origins a party state. The vast majority of members of the new social elite were in fact plebeians who had neither acquired nor strived to acquire private assets. Their newly-won social position was based upon the collective right to manage state-owned or other public assets. The ability of individuals to use these assets corresponded to their position within the hierarchy of power and social functions. This made the power vertical the base for social stratification in post-revolution society, something reinforced when Stalin and Molotov began to build the party vertical as a bureaucratic vertical. The actions and social standing of those in its lower ranks depended entirely upon the party bodies. Any loss of function made for a precipitous drop in social position, and this was true not only for those at the lower levels of the ranking system. It applied as well to those in the upper echelons of the power hierarchy who, in times of discord, frequently tumbled from their perch at the top down to the level of ordinary citizens or prisoners, or even found themselves facing a firing squad. This was the fate that befell those in the USSR who opposed the Communist Party or who fell out of grace with Stalin.

This type of society, growing as it did out of a plebeian revolution, was doubtless predestined from the start to give rise to authoritarian and totalitarian power structures. The social stratum now in control of government had no roots in any traditional counterpart. Rather, it built its position mostly if not entirely by controlling the power pyramid and its individual levels. Originally, it was possible to see in this pyramid the modernization of a vertical social structure, since it did enable movement and changes in its composition. This modernization connected the governing stratum to vertical networks of social and interest groups, but it was negative in many ways and had many negative outcomes.

The new government rendered the existence of 'non-Bolshevik' political parties and Communist 'deviations' impossible, thus leaving no one in opposition, but it did not forget the existence of interest-based, professional, or other public organizations. Members of the governing party had helped establish and operate these organizations in the past. They could therefore sense their potential social 
role, and used them to anchor their influence in society. The network composed of these organizations thus became an idiosyncratic replacement for a true 'civil society', assumed some of its functions, and bound a significant portion of the citizenry to the existing powers, making of them an organized 'backup' resource. Post-revolution organizations of this type functioned in society as further agents in the 'modernization' of authoritarian power structures, creating tools for mass influence over a large segment of the population in a scope that had been unavailable to earlier authoritarian systems and regimes. In a century characterized by mass political movements, this took on extraordinary importance. Recent historiography and political science rightly emphasize the conflict between the Soviet model of society and the interests of large segments of the population. But to gloss over the ability of Soviet-style political regimes to ensure and mobilize mass support from a large segment of their population for extended periods would be to gravely misapprehend the nature of these regimes. 



\section{The "Building Socialism" in the early $1920 \mathrm{~s}$}

\section{The War Communism and the NEP}

The implementation of Soviet economic policy began with a wave of expropriations of private businesses and other measures, necessitated by the post-revolutionary turmoil and the emerging needs of the Red Army. The latter safeguarded Bolshevik power during the civil war, which continued to be fought until 1920, the year in which the plan to construct a socialist society took on better defined contours. The set of economic relationships that came into being during this era later received the label 'war communism'. At the Tenth Congress of the Russian Communist Party/ Bolshevik in 1921, Lenin described these as measures that had been forced by the civil war.

But their true nature had come out at the All-Russian Congress of Soviets six months earlier, in December 1920, when a plan that had been proposed by Lenin's government to develop the nonmarket economy was approved. It anticipated that the monetary system would be abolished, along with the circulation of currency and monetary institutions, including banks. Peasants were to be relieved of their rights to manage their own assets and their farm produce. Industry, particularly heavy industry, was emphasized. It was to be funded by increased contributions of grain from the peasants, by borrowing and loans from abroad, and by granting economic concessions to foreign entrepreneurs. The energy to feed this construction was to come from increased oil and coal mining in Baku and Donbas and, in the future, from the extensive electrification of the country.

When in subsequent weeks a wave of uprisings swept the country as peasants reacted to newly announced changes in the government, Lenin revised the plan. Moscow and St. Petersburg were convulsed by strikes, setting the stage for the well-known Kronstadt sailors' rebellion. His hand thus forced, Lenin backed away from the basis of his own recently declared policy and announced the New Economic Policy (NEP). Its original impact was restricted to permitting a market economy on a limited, regional basis in response to peasant demands. But before half a year had passed, the government was forced to expand the scope of market relationships up to the level of the national economy, leading to the renewal of circulating currency and affecting industrial relationships. Prior to the 1923/1924 currency reform, the exchange of substantial part of commodities had continued in its natural form. 
This pre-history of Soviet economic policy itself is worth exploring. But it is also important because it was etched into the memory of the population and members of the governing party, where it stayed for the next twenty years.

The 1921 peasant riot, brutally suppressed by the Bolsheviks, and widespread famine resulted from Lenin's economic policy after 1917. The famine assailed more than 30 million people in the Volga Basin and an extensive area in Ukraine. Contemporaneous sources show that it killed 5.2 million people ${ }^{18}$, even with substantial aid from abroad, particularly the USA. But the consequences of the civil war and Lenin's economic policy were not limited to these material losses and casualties. They also greatly magnified the depth of Soviet Russia's World War I losses. The general post-war reconstruction of the economy therefore had to wait until 1923, and the national economy returned to its pre-war levels of performance only in the late 1920s.

1921 is significant for one other reason. The outcome of the war between the Soviet Union and Poland in 1920 put to rest the Bolshevik plan to abandon the Versailles Treaty, but the hope that the war's end would lessen internal political repression remained alive. The educated were among those on the receiving end of that repression, but so were a number of Bolshevik leaders. Life indeed improved for them in 1920, with intraparty discipline significantly relaxed as the result of efforts made in this atmosphere of hope, and concessions were also made to the intraparty opposition: a group of democratic centrists called the 'Decists' and the so-called 'worker opposition'. Representatives of moderate socialist parties were even invited to the Congress of Soviets in December of that year, where they were allowed to speak freely. By 1921, the controlling circle of the party proposed to reform and place limits upon the $\mathrm{Cheka}^{19}$ - the secret service-and to modify the Criminal Procedure Code by revising judicial procedures and toning down criminal prosecutions. This sense of relaxation was also reflected in civic life. The intelligentsia became more active and so did the organizations to which its members belonged. The press also benefited and unfettered discussions were

18 See Naseleniye Rossii v XX. veke: istoricheskyje ocherki. Vol. 1, Moscow, ROSPEN 2000, pp. 129-133. An estimate of the total number of casualties is missing. Data on population movement suggest a figure of around 3 million. The figure 5.2 million is indicated in the final report of Pomgol (Pravda, 13.10.1922).

19 Cheka was to be replaced by GPU (later OGPU), the All-Union State Political Administration, which was to lose its special power of attorney to hand down rulings. Cf. Plechanov A., Dzerzhinsky: Pervyj chekist Rossii. Moscow, Olma Media Grupp, 2007, pp. 516-532. 
allowed at the universities. Emigrants tried to convince the regime to let them come home and take up their activities. ${ }^{20}$

But there was a countertrend to this liberalization in evidence from the outset. Lenin treated the events of spring 1921 as a serious challenge to Bolshevik power and, supported by Cheka, systematically sought to maintain a repressive regime in the country. To the participants in the Kronstadt Uprising and the strikes and riots of spring 1921, Cheka meted out severe punishment. The intelligentsia's turn came in the summer and autumn of 1921. The key actions taken against them surrounded the 'revelation of the Tagancev Conspiracy', ${ }^{21}$ and measures targeting liberals who had begun a movement to help the starving. Lenin insisted on 'completing the liquidation' of SRs and Mensheviks resulting, in mid-1922, in show trials of the SR leadership and the attempt to force Mensheviks to abandon their own party. In parallel, he strived to suppress the independent activities of social organizations and the press, sought to place them under the control of security agencies, and acted heavy handedly against religious authority, in which he recognized a staunch enemy of Bolshevik power. This sweeping crusade against the educated led, in the summer and autumn of 1922, to an effort to completely suppress the activity of socialist parties and to chase politically active members of the liberal intelligentsia abroad. Their forced exodus was euphemistically referred to as the 'philosophers' steamboat', and with it, the regime was in effect permanently closed off from any effort at political 'liberalization.22

In 1920, a sharp escalation of the internal tensions and conflicting forces in leading party committees took place-in the Central Committee, the Politburo and the Secretariat. The source of this strain was originally personal disputes over the actions of Trotsky who, on the one hand, conscientiously skirted conflicts with Lenin, but whose independence and political actions, on the other, and the influence he held in the party, chafed against some in the leadership. ${ }^{23}$ When he

20 This primarily refers to the so called Smenovekhovtsy, a Russian emigre group, which counted on the gradual evolution of Soviet power.

21 Tagancev was a high functionary in the Academy of Sciences, which at that time was based in Saint Peterburg. Many leading figures in scientific and cultural life were impacted by this case.

22 Kommunisticheskaya partiya Sovetskogo Soyuza v rezolyutsyakh i resheniyakh s"ezdov, konferentsii i plenumov TsK, Vol. 1. 1898-1925, Moscow, Gospolitizdat, 1953, pp. 669-674.

23 Disputes between Lenin and Trotsky are described in a plethora of legends cultivated by Stalinist historiography. Trotsky was aware of the Lenin's irreplaceable role in the party and avoided conflict with him. The fact that he was an assimilated Jew and therefore 
proposed in spring of 1920 to jettison the mandatory purchase of grain in favour of a fixed agricultural tax and a bonus system, Lenin rejected him outright, fearing these changes would liberalize the market.

Grave conflicts between Lenin and Trotsky soon followed during the war between Soviet Russia and Poland. Lenin euphorically anticipated Poland's defeat would come quickly and the 'Versailles peace system' would collapse. His enthusiasm was dampened by Trotsky and any other leaders, who counselled a quick end to the war. This stoked the discord between Lenin and Trotsky, culminating in the so-called trade union debate of autumn 1920. With the transport system under his command, Trotsky wished to remedy its catastrophic condition by militarizing the workplace with a command system of strict discipline and control under a single political centre. He was blocked by the unions. Believing that, in a nonmarket economy, they had lost their original purpose of looking out for workers' social interests now cared for by state owned companies and economic bodies in the 'proletarian state', he launched an attack against them.

Lenin was originally of the same mind as Trotsky, but he relied upon his own circle in the party leadership to prevent conflicts with unions. Its members included Stalin, Zinoviev, Kamenev, and Tomsky. Lenin proposed that Trotsky summarize his opinions in the form of a special 'platform', and when he had refused, Lenin labelled him a 'faction creator.' Lenin then proposed that votes for delegates to the upcoming Tenth Party Congress be made on the basis of faction affiliation, even though the intense debate generated within the party led him to neglect a dangerous situation in villages caused by the reinforcement of the 'war communism' policy proclaimed at the prior Congress of Soviets, which policy had, as noted, provoked widespread peasant uprisings. He freed himself up enough to juggle cadres in the party leadership and in so doing, to secure the exclusive standing of his own faction. He employed repression and used the military as a hammer to deal with the urgent situation in the villages, at the same time as he updated Trotsky's 1920 proposal to free the market, initiating the transition to the NEP, the New Economic Policy. ${ }^{24}$

This was a crucial development. Trotsky was banished to the fringes of the party leadership. Soon after suppressing the Kronstadt sailors' uprising and the mass

unacceptable as head of the country to the Russian establishment also played a substantial role in his attitude.

24 See Pavlyuchenkov, S. A., Krestyanskiy Brest, Moscow, Russkoe knigoizd. tov. 1996, pp. 158-159. Trotsky, Sochineniya, Tom 17, Part. 2, Moscow-Leningrad, Gosizdat 1924, pp. 543-544. The relation between Lenin's and Trotsky's text is demonstrated by simple comparison of their content and a number of formulations. 
revolt of peasants, in which the part he played was purely formal, he took a 'holiday'. Only in autumn of 1921 did he reappear on the political horizon to criticize the protracted, improvisational manner in which the NEP was being introduced, and the feckless interventions of party bodies in the economy. Later, to restore the broken ties of collaboration in industry and to weaken the influence of inflation on industrial plants, he strived to employ planning. In this he was at odds with Lenin, who argued that the nature of relationships among peasants was such that no plan could be enforced. Lenin ended up accepting his proposals when Trotsky excluded rural areas from the plans. From an ideological standpoint, the support Trotsky provided for Bukharin's concept of state owned companies as socialist enterprises was more consequential. It erected a barrier between agriculture and industry that stood in the way of efforts to expand the NEP.

These disputes between Lenin and Trotsky soon lost their significance. More critical was Lenin's new turn further to the left and his repressive actions within the party. This leftward turning was heralded by the slogan 'An End to the Retreat' in the spring of 1922. Private business, particularly private commerce, was restricted. Lenin, then seriously ill, argued fiercely at the Eleventh Party Congress against any expansion of the NEP. The stance he took on developing international economic relationships had profound consequences, with his statements at conferences in Genoa and the Hague helping to thwart the chance to get loans and credits from the European Allies to consolidate Soviet Russia's economy. He likely believed that Europe had a viable interest in the Soviet market, and Soviet Russia had time to await more favourable offers. In autumn of that same year, Lenin's demurral cost the country a substantial concession from Lesley Urquharth, blocking chances a broader concession policy would be launched. At the same time, Lenin's agreement with Trotsky frustrated the proposals of his own central committee to weaken the foreign trade monopoly, both men afraid of corruption and the Soviet economy 'being robbed' from abroad. Trotsky later justified this by saying the USA was capable of buying the entirety of Soviet industry at bargain rates. Taken together, these decisions curtailed the growth of the Soviet international economic relations. No recovery ever took place, and the Soviet economy was condemned to autarcic development.

Near the end of Lenin's time in government, Trotsky issued a report on industry that took into account the significance of the marketplace and the role it played, and it became the leading proposal for development of the Soviet economy. Presented at the Twelfth Congress of the RKP/b, when Lenin due to his illness failed to participate in politics, the report highlighted industry's key role in the economy and the large investment that would be necessary for its start-up, particularly in the case of heavy industry. Once underway, Trotsky reasoned, 
industrial operations would increasingly accumulate the assets needed for their own development, making a proper start-up especially critical. He stressed the use of economic indicators: work productivity, profit and loss, production calculations, and accurate accounting as well as the effective organization of production. He recommended that industry be developed using plans comparable to those made by large capitalist firms and monopolies. These would contribute to restoring ties between companies, providing them with the raw materials and energy they needed, and would encourage collaboration between firms and mutual sales of production. He was vociferously opposed to political bodies interfering in the running of the economy.

Despite the claims of later Soviet historians, Trotsky also focused closely on the relationship between the cities and rural areas, and was the first to analyse the well-known 'scissors' problem of the disharmony between industrial and agricultural prices. The remedy, he thought, lay not in setting their levels administratively, but rather in rationalizing production, spending effectively, increasing worker productivity, and eliminating inefficient costs. Another target was the issuance of currency as a cause of inflation and the significant role of barter in the economy. Trotsky was against excessive agricultural taxes because they blocked the reproduction of peasant farms; he saw in food exports a chance to benefit from higher prices in the international marketplace; and he warned that low levels of activity by state businesses would promote the accumulation of assets in the private sector.

Trotsky's report, presented on behalf of the party leadership, would seem to have allowed for a new tack to be taken in dealing with economic issues. But this only partially came to pass, due to the relationships among party leaders at the time of Lenin's exit from political life. Because of this, we may definitively state that no comprehensive plan for the economic development of the USSR emerged from the Lenin era, only certain prerequisites for economic and social stabilization.

\section{The Events of 1923 in Germany and the Origin of the "Left Opposition" in the USSR}

At the time of Lenin's departure, the country remained mired in unfavourable economic and social circumstances. Agriculture was only slowly recovering from the 1921 famine. In the succeeding year, crops were still at three-quarters of their pre-war average, industrial production at one-quarter, and foreign trade at just fourteen percent. Heavy industry and machine production were using ten percent to forty percent of their actual capacity, wages were half their pre-war levels, and work productivity was sixty percent of what it had been. Raw iron was in 
short supply; some factories had to be closed. Coal production was dropping, as were shipments of oil from Baku and Grozny, and only one quarter of the engine stock in the railroad system was operable. ${ }^{25}$ And a crisis situation in the governing party loomed.

Lenin's impending exit from politics had probably been taken into account by the time he fell ill in 1921/1922. Posts were handed out to members of his faction at the time of the Eleventh Party Congress in spring 1922, likely with his agreement. Zinoviev remained chairman of Comintern and managed intraparty affairs in St. Petersburg and environs, but additionally, he tried to claim the role of ideological leader of the party. Kamenev was in charge of Moscow. He presided over the Politburo in Lenin's absence and the government, as a potential successor to Lenin, although Lenin also considered Trotsky for the position of Prime Minister. Control of the party Secretariat and thereby the party apparatus was given to Stalin, whose territorial fiefdom in the Caucasus was managed by Grigory Ordzhonikidze. The significance of the party secretary's role was underestimated at that time, but was made clear when Zinoviev and Kamenev granted Stalin a monopoly on visiting the ailing Lenin, whose wishes and proposals Stalin then passed to the party leadership. By the summer of 1922, he was already a key figure in the party leadership, significantly strengthening his position by systematically building and reinforcing the party apparatus, assigning posts to people who were utterly dependent upon him.

Lenin's resistance to placing Stalin in this position, and to the way he operated, is well known. It became apparent as early as autumn of 1922, when Lenin briefly resumed his functions. Three issues lay at the centre of their failure to see eye-toeye: the national question; the way by which the Soviet republics should be united into a country, which Stalin planned to do through the bureaucracy, as an act of the apparatus; and Stalin's gradual usurpation of power within the party. Other points of disagreement had to do with economics, with the future of the NEP, and with economic contacts abroad. Evidence of their bitter dispute may be seen in Lenin's recommendation to oust Stalin from his position as General Secretary, and to appoint Trotzky as Deputy Prime Minister. Trotsky turned Lenin down. He thought his Jewish origin would make him permanently unpalatable to the Russian establishment in this position. In any event, Lenin's wish to oust Stalin was not respected by his political friends Zinoviev and Kamenev, who were more

25 Dvenadcatyi syezd RKP/b, 17-25. Aprelya 1923g., Moskva, GIPL 1968, pp. 29-33; Ekonomicheskiy vestnik No 1/1923, pp. 154-159; Vladimirov M., Tezisy k byudjetnomu planu 1922-23, in: Vestnik finansov, No 6, 9.2.1923. 
afraid of reinforcing Trotsky's influence. The sole concession made to the ailing Lenin by the Politburo was to accept his proposal for making the USSR into a federation of Soviet republics, but it was Stalin who was authorized to report on the issue at the Twelfth Congress of RKS/b, and this dulled its critical edge. Stalin was also given a free hand to deal with his opponents, including making changes to the party leadership in Georgia and Ukraine. ${ }^{26}$

As early as the summer of 1923 , the party was staring into the face of an internal conflict. But a head-on confrontation was avoided by Trotsky, whose political independence and influence within the party placed him in a leadership role. $\mathrm{He}$ did not have enough support to win and was likely waiting instead for Lenin to get better, or for the party's configuration of power to change. Only with reluctance were Zinoviev and Kamenev willing to get involved, and anyway they remained closer to Stalin than Trotsky, in spite of the danger the former posed to them.

But the growing schism was neither the case of personal and political relationships, nor was it about factual or ideological conflicts. The major source of strain in 1923 was the rapid consolidation and reinforcement of the bureaucratic power vertical, which left no room for pluralistic elements in the political and social system in the USSR. The urban middle stratum, weak in power, had already been dispersed during the revolution and the civil war. Its remaining members were condemned to the role of 'expert', providing scientific knowledge and experience the regime needed, but they had no leverage to influence power decisions. Nor did the peasant stratum provide a base from which an opposition might arise. They, too, were scattered across the countryside, unconnected with each other, and lacking the needed culture and education. They thus had no chance to independently organize to protect their own interests. Independent peasant organizations were barred; their 'alliance with the proletariat', code for the governing party, remained an empty phrase without real meaning.

The only space left for the opposition to express itself was within the governing party and it was minimal, a space that could be used by party officials and, to some extent, by functionaries and members of party organizations who for any reason did not agree with party policies. Stalin's new bureaucratic party apparatus lacked the strength and consolidation to fully control the party life. But the party

26 Immediately after the Twelfth Congress of RKS in early June 1923, Stalins' political allies allowed him to call a meeting with representatives of the national republics and regions, an opportunity for Stalin to justify nationality-based repression against his opponents. See Tayny natsionalnoy politiki CK RKP: Stenograficheskiy otchet IV. soveshchaniya CK RKP, 1923 g. Moscow, Insan, 1992. 
saw itself as surrounded by a hostile foreign environment and therefore clung to its overall sense of unity.

That sense of unity was challenged soon after the Twelfth Congress of the $\mathrm{RKS} / \mathrm{b}$ when Stalin started making substantial changes to personnel in Moscow and around the country. Among the casualties were the leadership of the Georgian party, which was in revolt, and the Ukrainian party leadership, headed by the influential and politically independent Christian Rakovsky. But that was not the end of it. In following Karl Radek's advice to change Soviet policy on Germany, he rewrote the job descriptions of Zinoviev and Bukharin. Against the latter's will and in his absence, Stalin also replaced representatives in the Moscow editorial offices of Pravda. The leading party trio of Stalin, Zinoviev and Kamenev thus diverged. Zinoviev backed away from his trenchant anti-Trotskyism. In a closed-door meeting of party leaders in the South of Russia, he recommended creating a new leadership trio comprising Stalin, Trotsky and one of Kamenev, Zinoviev himself, or Bukharin, but Stalin resisted and Trotsky had no interest.

At that same meeting, the disparities over the Soviet German policy became apparent. In early 1923, French and Belgian units had marched into Germany's Rhine and Ruhr regions hoping to force the country to meet the financial obligations that followed its defeat in World War I. The German government of Wilhelm Cuno responded by cutting contact with both countries, suspending reparation payments, and insisting German citizens, companies, and institutions engage in passive resistance. But this brought serious consequences for the country. Inflation skyrocketed, the monetary system collapsed, and both wages and savings lost their value. The government resigned. The population was radicalized. In addition to the left-wing social democrats, the beneficiaries were the radical left and the nationalist radical right-Communists and Nazis alike.

While the German crisis of 1923 itself has been treated extensively in the literature, its impact on the situation within the USSR has not. Germany's troubles came at a time when Stalin's hunger for power was causing increasing conflict inside $\mathrm{RKS} / \mathrm{b}$. The expectation that Germany was veering towards revolution led Zinoviev and Trotsky, each in his own way, to anticipate that the USSR's power structure might turn in a direction favourable to them. A successful revolution in Germany would place it centre stage, undermining Stalin's position. Trotsky and Zinoviev felt emboldened to put forth radical propositions that Stalin felt he had no choice but to accommodate. ${ }^{27}$ In reality, though, Germany was not at

27 See the documents and studies in: Deutscher Oktober 1923: Ein Revolutionsplan und sein Scheitern. Hrsg. Bayerlein B.H., Babičenko L. G., Firsov F. I., Vatlin A. JU.: Berlin, 
the combustion point. The new Stressemann government, which included social democrats, utilized help from the army leadership and navigated the situation facilely, isolating both the radical right and the radical left, with damaging consequences for the German-Russian relationship when the German government turned towards closer collaboration with the Allies and the League of Nations.

In the USSR, Stalin's opponents were far from united. Trotsky's attitude was sharply different from Zinoviev's. Trotsky supported radical progress in Germany, but he did not buy into Zinoviev's ambition to 'manage the German revolution', believing such a notion was a waste of time and of the opportunities that might be seized. He waded into the 'German revolution' dispute just after Stalin had adopted certain parts of Zinoviev's proposal, initiating active preparations for the German revolution. Stalin and Zinoviev jointly tried to suppress Trotsky's influence.

In dealing with the events in Germany, Trotsky was hampered by the fact that the party apparatus had taken over the awarding of army posts, which had formerly been part of his competence as People's Commissioner and Chairman of the Military Revolutionary Committee. He was also challenged to 'expand' the Military Revolutionary Committee, including among its new members Stalin. The point of these changes was clear: not just to remove the army from his control, but also to goad him into rebelling. ${ }^{28}$

In response, Trotsky walked out of the RKS/b Central Committee meeting, following this on 8/10/1923 with a letter to its members and those of the Central Control Commission sharply criticizing the work of the 'trio', whom he accused of suppressing intraparty democracy and escalating intraparty tensions, as well as of giving rise to 'a mindset specific to the secretary characterized by the secretary's conviction that he can resolve issues... without knowing their substance.'

Aufbau-Verlag 2003. These attitudes were also manifested in a dramatic request presented by Trotsky to be sent to Germany, where he had significant influence over the KPD leadership. Many Soviet politicians, soldiers and security agents tried to influence the situation, but Trotsky was too well known and him working directly in Germany could not be considered. Vatlin A. Ju., Komintern: Idei, resheniya, sudby. Moskva, ROSSPEN, 2009, p. 115; Deutscher I., Trotzki, Volume II, Unbewaffnete Prophet 1921-1929, Stuttgart, Kohlhammer, 1962-1963, p. 160.

28 See RKP/b.Vnutripartiynaya bor'ba $v$ dvadcatyje gody, Dokumenty I materialy $1923 \mathrm{~g}$., ed. Vilkova V.P, Moscow, ROSSPEN, 2004; p. 20; Pavlyuchenkov S. A., "Orden mechenostcev": Partiya i vlast' posle revolyucii 1917-1929., Moscow, Sobraniye, 2008, pp. 296-297; Erickson, The Soviet High Comman, a Military-Political History 1918-1941, LondonPortland, Franc. Cass, 2001, pp. 141-142 RVR - Military Revolutionary Committee. 
Trotsky went on to claim the trio ignored the resolutions adopted at the Twelfth Congress, and adopted a price policy that meant a return to the period of war communism, since two boxes of matches cost as much as a 'pud' of bread. ${ }^{29}$

In speech, Trotsky didn't hold back, and his letter was the harshest, most critical that had been seen in the post-revolution history of the party. Forty-six influential party figures signed the letter, albeit with some reservations. Trotsky had much chance to win the conflict, but his efforts were not without effect. The changes made in the party were so rapid and so pronounced that, as noted above, even Zinoviev and Bukharin initially protested. By late autumn of 1923, the discussion expanded to involve even basic party organizations, and influence the attitude of the intelligentsia and 'experts', as well as the European communist parties. When the German revolution failed, the discussion intensified, with the party leadership and Zinoviev, as chairman of Comintern, held responsible.

The situation in the party was grave; the party leadership was forced to compromise. In late November 1923, the leadership charged a committee consisting of Stalin, Trotsky and Kamenev with preparing a compromise proposal for resolution. It suggested a change in the way the party was run and that it be based upon the principles of 'worker democracy'. The principle of electing party functionaries was to be 'strictly respected', as was the 'need' for free discussions on key party policy, without party discipline being used as a pretext for squelching discussion. But the compromise fell apart within three days. Trotsky published an article entitled 'The New Direction' in Pravda, offering his interpretation of the resolution. He said democracy could not be granted to the party by simple decree but was something that had to be fought for, something by which the party apparatus must be governed. And it was to be judged by the mood of the youth. Although the older generation was rightfully entitled to a leading position in the party, it was more susceptible to stress and bureaucracy. And bureaucracy, Trotsky opined, was what had given rise to bureaucratic factions that blocked discussion and stifled criticism. ${ }^{30}$

Trotsky's article made clear that the party leadership and the opposition sharply differed on democracy and party reconciliation. The leadership distanced itself from Trotsky's article, declaring it a malicious attack against the party apparatus and the older generation in the party. Under Zinoviev's influence, extraordinary measures were put in force, censoring the press, distorting the history of the discussion within the party, and falsifying intraparty voting. The discussion thus

$29 \mathrm{Sb} . \mathrm{RKP} / \mathrm{b}$, Vnutripartiynaya bor'ba, pp. 156, 159. Pud - $16 \mathrm{~kg}$.

30 See RKP/b, Vnutripartiynaya bor'ba, pp. 296-302. 
came to an end without his input, and the impact of this was considerable. Trotsky was released from performing his duties on 'doctor's orders' by the Politburo and sent to the Caucasus for treatment. ${ }^{31}$ As a result, he missed Lenin's funeral and the party conference that took place in January 1924 in Moscow, which labelled the opposition a 'social-democratic perversion' within the party. It was not excluded from the party altogether; but its members were systematically ousted from leading positions, providing new manoeuvring room for Stalin to usurp power and for the bureaucracy to grow.

\section{The Party and the Opposition after Lenin}

1924 was a breakthrough year in stabilizing the regime. It started with Lenin's death in January, which brought to an end a two-year period during which no reorganization of power had been possible. Then there was the defeat of the opposition: Trotsky's exit from key party functions and from the government was just a question of time. After a long stay in the South, he took part only in the Thirteenth Congress of the RKS/b, declaring his fidelity to the "party", but accompanying this declaration with a reiteration of the basic themes of his 'New Direction' essay. ${ }^{32}$ At the end of the Congress, Trotsky remained a nominal member of the Politburo and of the Comintern executive committee, but key decisions were often made behind his back or in his absence.

Stalin's position, meanwhile, was significantly strengthened. At Lenin's funeral, he presented himself to the public as the new leader of the party. In spite of the fact that Kamenev had been Lenin's deputy for two years, Stalin was able to prevent him from taking the Prime Minister's post. Stalin insisted instead upon Alexei I.Rykov as the head of government. Rykov was considered an experienced politician and overseer of the economy, but he lacked the charisma to aspire to a position comparable to Lenin's. ${ }^{33}$ The party's top leadership also changed after the Thirteenth Congress, with the former trio of Stalin, Zinoviev and Kamenev giving way to a 'Group of Seven' consisting of Stalin, Zinoviev, Kamenev, Rykov, Tomsky, Bukharin, and Kuibyshev. But in addition to trying to rid himself of Trotsky, Stalin was trying to push Zinoviev and Kamenev from their leading positions,

31 Izvestija, 8.1.1924. He had allegedly fallen ill as early as 5/11/1923 and thus did not take part in the discussion during the key last two-and-a-half months.

32 At the congress, members of the opposition (Preobrazhensky, Radek, Pyatakov and Trotsky) were present but with only a consultancy vote.

$33 \mathrm{He}$ argued it was necessary for the government to be led by a native Russian and Kamenev came from a mixed Russian / Jewish family. 
and perhaps other members of Lenin's government. At the Thirteenth Congress of RKS/b, he easily sidestepped the blow he might have suffered from the recommendation in Lenin's 'Testament' that he be removed from the position of General Secretary. ${ }^{34}$ The Testament had not been presented to the plenary session of the Congress, only 'discussed' by leading functionaries, and it was strictly forbidden to talk about it, whether in public or just within the party.

Lenin's role in the state had been determined by his position as Prime Minister, but Stalin did not aspire to this position. With his standing and that of the party apparatus reinforced by the changes, the centre of power had shifted to the party and the new power role played by the apparatus. The USSR was becoming a party state, in which the party bureaucracy overshadowed the state bureaucracy. The government of the country thus took on a new form. With the centre of power now outside the government proper, there could be a single, transparent, centre controlling not only the security services, the military, the courts, and the economy-as was traditional-but also interest groups and social organizations not connected to the government, particularly unions. The same centre could also be used to combine control of foreign policy with 'nongovernmental' actions taken by Comintern and by 'nongovernmental' international organizations.

In the end, these changes also led to alterations in the composition and function of party organizations. They came in with the mass recruitment effort begun in 1924 as part of the 'Lenin Enrolment', which brought 200,000 new members to the party. By mid-1927, the party was half again as big as it had been in 1922, and those who had entered in 1924 or later accounted for sixty percent of those in its ranks. The composition of party organizations in Moscow, St. Petersburg, Kharkov, Kiev, and other cities that had formerly had a strong opposition presence changed as well. The education level of the new members was poor: only $63 \%$ had completed primary school, $26 \%$ were self-taught, and only $0.8 \%$ had attended or were attending university or were university graduates. ${ }^{35}$ The changes wrought made the party organization completely dependent on the instructions of the party apparatus and members were introduced to a new 'party education' program featuring Stalin's take on party ideology and history. Thus a new state-political organization came into being in society, tending toward what was to become a totalitarian or single-party state.

34 "Testament" - a set of Lenin's final, sharply critical notes. They were designated for the party congress and presented to the party leadership by his widow, Nadezhda Krupskaya.

35 Nashe otechestvo: opyt politicheskoy istorii, ed. Kuleshov S. V. Volume 2, Moscow, Terra 1991, pp. 226-227. 
At the time of their institution, however, these changes were primarily directed at suppressing the 'Trotsky opposition. There were rumours within the party that Trotsky might be preparing a military coup, even though Trotsky's most serious problem as administrator of the military was his isolation in the party's controlling bodies. His exit from the military had in fact become inevitable; all that was left to decide was when and under what circumstances it was to take place. His own preference was to switch to a leadership function in the economic sector. But the party leadership instead placed him in the peculiar position of a 'minister without portfolio, deprived of any real share in power.

The incentive to remove him completely came soon when, in 1924, a collection of work that had been written in 1917 was published with a preface by the author. It was titled 'The Lessons of October'. By the very fact that it reminded public and party of the role Trotsky played in the Bolshevik seizure of power, it provoked the party leadership. That the book's preface spoke of fresh experience gained in the failed 'German revolution' of 1923, with Trotsky comparing control of the revolution to the approach taken by Zinoviev and Kamenev in October 1917, grated even more. His diagnosis was: a failure of nerve and an inability to fight for power.

Today, there is no point in trying to guess why Trotsky's polemic targeted Zinoviev and Kamenev, whose roles during Lenin's illness and after his death were less than admirable, but there was nothing in The Lessons of October outside the bounds of a political polemic. The party leadership responded with feigned outrage nevertheless. It tried to permanently discredit Trotsky by claiming the existence of 'Trotskyism' as a distinct ideological stream from 'Leninism'.

The entire matter was presented to the Plenum of the Central Committee of RKS/b in mid-January 1925. Trotsky did not attend the meeting. Excusing himself on the basis of illness, he tendered his resignation to the Plenum for his functions in the armed forces, in line with Stalin's intent, thereby freeing Stalin to focus on the conflict with Zinoviev and Kamenev. This conflict was not without its twists. Stalin had been against Zinoviev's proposal, supported by Kamenev, to oust Trotsky from the Politburo and the Central Committee, proposing to leave the decision up to the party congress. Zinoviev argued the step was necessary because Trotsky was 'changing into an anti-Bolshevik,... a tool in the battle against communism. ${ }^{36}$

36 G.Zinoviev, O nieobchodimosti trech perestrakhovok. A report on actions taken by the Central Committee at the Leningrad party conference. Pravda, 26.1.1925. 
This resulted in a kind of schizophrenia within the party. The campaign against 'Trotskyism' was not really about the critical analysis of the man's work but rather about dismantling his standing as a leader. The party leadership thereby shucked off the need to evaluate his work positively and, if anyone else offered a positive evaluation, it was portrayed as a manifestation of 'Trotskyism'. Both the party and the people were told to forget about Trotsky's role in 1917 and during the civil war, even though every citizen of the country recalled it well. In reality, even more serious issues were at stake. Although Stalin had distanced himself from Zinoviev's proposal, the anti-Trotsky campaign opened the door to changes in the balance of power in the country. The intraparty opposition was being portrayed as an 'enemy force', and sanctions against its members came with a new ferocity. Large groups of party functionaries were excluded from political life, as were critically inclined members of the party's intelligentsia.

\section{The Opposition and the NEP}

The detail with which we have delved into the political aspect of the turn against Trotsky and the opposition in 1923-24 has also been partly motivated by the lack of any significant push to resolve the social and economic development issues the country was facing, or to decide the fate of the NEP so favoured by Soviet historians of the era.

At the Twelfth Congress of the RKS/b, Kamenev let fly an accusation that Trotsky had underestimated the peasantry and hence the role of the Communist Party. He likely did so to reinforce Stalin's position, which had been threatened by Lenin's criticism. ${ }^{37}$ But Trotsky's report at the Congress contained nothing that would justify Kamenev's claims or those of the trio as a whole. Setting aside Trotsky's objections that the trio had paid no real attention to equalizing agricultural versus industrial prices ${ }^{38}$, one can see that the remaining conflicts between the opposition and the party focused almost exclusively on intraparty issues. Party leadership blamed Georgy L. Pyatakov for the disproportionately high industrial prices. As Vice President of the Supreme Soviet of the National Economy, the VSNCh, he had recommended that industrial facilities set high prices for their products to counter their acutely limited turnover. ${ }^{39}$ But the real cause of

37 The initiative was probably left to Kamenev because he was preparing a report on party policy in rural areas to be presented at the Congress.

38 This refers to the Trotsky's document dated 8.10.1923.

39 In his "Testament", Lenin appointed Georgy L. Pyatakov one of the six leaders of the governing party. 
the country's economic difficulties in that time was more complex. The spring of 1924 had brought the party leadership great economic success when it managed to transition the USSR to a stable currency, with a significant impact on the country's financial policy. Before it arrived, the transition to the new currency was no secret, and this was visible in the attitudes of the peasantry, who paid taxes in the old currency but postponed grain sales so that they might enjoy the yield in the new currency ${ }^{40}$. Trotsky, however, stressed not just price equality, but also the need to jumpstart industry, which was still languishing deep below its pre-war levels. He maintained proper pricing required greater industrial production and more industrial goods on the market, responding to Kamenev's recommendation for a slower pace by saying, 'The world market isn't waiting, and the man on the street won't want to wait either.'

But in addition to existing economic difficulties, the party leadership was also confronted by the fact that Trotsky continued to be the author of its economic policy. Top party leaders wanted to claim their own economic development concept, but the fact was that if they did not wish to refer to Trotsky's ideas-notions they had called 'social democratic perversion'-they had no concept to talk about.

Starting up industry, the chief economic concern of the time, however, needed massive investment, but the current state of the Soviet economy left little room for accumulating capital. Everything available to the governing party had been mentioned in Trotsky's report to the Twelfth Congress. The only thing that could make a significant dent in the situation was investment and loans from abroad. But the government was anxious about becoming dependent on foreign partners for a long period of time. At the international level, it also faced the condition that Russia's pre-revolution debt be settled and that foreign businesses whose assets had been nationalized be provided restitution. The Soviet leadership was only willing to go so far, and then only provided it would acquire advantageous longterm loans and credits. ${ }^{41}$

1924 was a turning point, not only in terms of the party's internal workings, but also with regard to foreign policy. A number of Allied powers had recognized the Soviet government de jure and expressed willingness to discuss controversial issues. The change in position taken by Britain and France seemed significant. In

40 Taxes to force peasants to sell grain or pay the tax in kind did not have the desired effect, because peasants had the opportunity to pay the tax in devaluated currency.

41 They were to provide for the startup of industry, whose profit would then be used to pay not only for the interest rate but also for Russia's pre-revolution debtswith the exception of war debts. In terms of the restitution of nationalized property, an opportunity to seek agreement with original owners was sought. 
the December 1923 elections, a coalition of Labour and Liberals came to power led by James Ramsey MacDonald that tried to normalize contacts with the USSR. The negotiations were difficult. The British government could not back down from its demands of the USSR-it had to take into consideration the dismissive attitude of business and the political sphere to concluding Anglo-Soviet agreements. In France, where the new government of Edouard Herriot wished to improve French-Soviet relationships, negotiations took a similar course.

In Britain, where the Soviet government was represented by Christian Rakovsky, lately Prime Minister of the Soviet Ukraine, negotiations seemed promising. In early August 1924, two British-Soviet agreements were signed: a General Agreement, and an Agreement on Trade and Maritime Shipping. These made it possible to negotiate debt and compensation for the British owners of the nationalized assets. The British government was to guarantee the USSR a loan of about 400 million rubles to fund Soviet reconstruction and cover British receivables. Rakovsky returned victorious to Moscow, and what had transpired in Britain was used as an example to aid negotiations with France.

But it soon became apparent that the degree to which relationships between the USSR and foreign countries had changed had been overestimated. British Conservatives launched a campaign against "interference by the USSR" in the internal affairs of Britain' and it split the coalition. ${ }^{42}$ New elections were called and the Conservatives won, suspending ratification of the agreements, which had already been signed, and British-Soviet negotiations. This then had a significant effect on the Soviets' negotiations with the French, where no rapid success resulted.

These developments abroad had serious implications for the internal political situation within the USSR. Stalin and his companions strove above all to avoid anything which might give impetus to resuming intraparty discussions. He made up his mind to split with Zinoviev and Kamenev, but this required playing down his disputes with Trotsky and his followers to make any potential agreement they might reach with Zinoviev and Kamenev more difficult. Thus the internal political discussion moved away from the party's life to the resolution of economic issues whose progress depended upon what the 'trio' and 'group of seven', with joint responsibility for economic issues, decided.

42 The pretext consisted of Zinoviev's 'letter' which was to contain instructions for British communists. It was a forgery and its author has never been uncovered. The USSR reacted with a statement from Rykov's government dated 27.10.1924 and a record of a discussion with Zinoviev. Izvestija, 28. and 29.10.1924. 
The original impetus to change the subject of the discussion came neither from Stalin nor from Zinoviev and Kamenev ${ }^{43}$. Legend among Soviet historians ascribed it to Bukharin, who was perceived by party leaders to be a promising representative of the 'younger generation of leaders, someone who enjoyed the sympathy of the younger party intelligentsia. But his political attitudes were volatile and he failed to understand the consequences his attitudes entailed. ${ }^{44} \mathrm{He}$ gained particular renown in internal party discussion for his gross attack on his former political 'friend' Yevgeni A. Preobrazhensky. In autumn of 1924, Preobrazhensky had discussed how best to ensure the needed capital accumulation in the USSR while the country was under international isolation. His thoughts appeared in the pages of Kommunisticheskaya Akademiya, a magazine targeting a narrow circle of the Communist intelligentsia. ${ }^{45}$ To his merit, he based his thinking on the Marxist concept of 'initial capital accumulation', concluding that the industrialization of the USSR would be accompanied by phenomena identical to those which had accompanied the development of capitalism in Europe.

Bukharin's response, however, was untrue in the way that it did not target a narrow circle of readers, but rather was published in Moscow Pravda in the form of an extensive article that Pravda's readers were not qualified to assess, especially because they mostly had not seen Preobrazhensky's article. Bukharin's reasons for writing the article were also not entirely laudatory. He drew connections between Preobrazhensky's thesis and Trotsky's 'Lessons of October', suggesting to Pravda readers that it was part of a broad new attack against the party by the 'opposition. But Bukharin approached the essence of the matter only superficially. He relied upon the outrage that would be generated among Pravda's readers by Preobrazhensky's comparison of the development of the Soviet economy to that of the capitalist economy. Preobrazhensky had concluded that, given Russia's prerevolutionary development and its losses during World War I and the USSR

43 The report was presented to the Central Committee at the Thirteenth Congress of RKS/b by Zinoviev. (Stenograficheskiy otchet, Moscow, GIPL, 1963).

44 Bukharin contributed to the 1923 discussion by "revealing" the plans made by the "left communists", to whose leadership he had belonged. These plans consisted of an alleged agreement with the "left SRs" made in spring 1918 to apprehend Lenin and thwart the signing of the Brest-Litovskpeace treaty. After 1917, Bukharin's sympathies shifted from Trotsky (1921-22) to Lenin (1923) and later to Zinoviev and Kamenev (also 1923), thence to Stalin (1924-25) and finally to Rykov and Tomsky with whom he tried to prevent the extremes imposed under Stalin's 1926-29 policies.

45 This was a treatise entitled "Osnovnoj zakon socialisticheskogo nakopleniya", published in "Vestnik Kommunisticheskoj Akademii", No. 8. 
civil war, there would be nothing to fall back on but 'initial capital accumulation' and funding drawn from rural areas. Preobrazhensky's focus was on economics, the marketplace and the politics of state; Bukharin's was on party ideology and prejudice. Preobrazhensky believed the growth of industry would saturate the market, and would encourage peasants to bring their produce to market, thereby paying their 'tax' for the benefit of industry. Industrial growth would also enable poor people in rural areas to leave for the cities, reducing their overpopulation and their consumption of agricultural production in their own rural areas immediately.

At the time, Bukharin's noisy entry into the internal party discussion was probably not in accord with Stalin's intentions. The latter was satisfied with Trotsky's resignation from his positions in the armed forces. The real impetus for the party leadership to initiate a new phase in its economic policy came not from Bukharin's article but rather from Rykov's visit to the Volga basin in September of 1924. He was shattered by the poverty he saw in Russian villages, prompting him to call for investment and improvements in the peasant economy. The industrial market had to expand and the conditions for its growth had to be created. ${ }^{46} \mathrm{He}$ expanded this to include a need for 'civil peace' and 'maintaining Soviet law' and, with the support of Mikhail Ivanovich Kalinin, the Chairman of VCIK Soviets, wished to find out who among villagers was a 'kulak' - a wealthy peasant. By spring of 1925, this discussion had given rise to a number of measures enabling economic growth for the upper strata of rural residents by means of soil rental, the employment of a hired workforce, improved lung conditions, and so on.

In early 1925, the party leadership decided upon accepting the general outlines of Rykov's economic policy. It expressed this with the slogan 'Facing the Village'. But the ideological turn this represented for the Soviet leadership was not without its contradictions. At the end of 1924, indicators show the gross volume of agricultural and industrial production had visibly risen, but this growth was attained by relaunching old, temporarily mothballed facilities into operation. The resulting industrial production covered only a quarter of the villages' needs. In its nature and its structure, it therefore simply documented the need for key changes to be made and for investment that would target sectors that could ensure rapid industrial growth. Securing the development of energy, machinery, transportation and agricultural equipment was fore grounded, but the substantial increase in the scope of industrial investment this required also prolong the waiting time

46 Rykov, Ocherednye zadachi sovietskogo stroitel'stva, Izvestija, 16.1.1925. 
for returns to appear. ${ }^{47}$ And after his experience negotiating with England and France, Rykov was forced to acknowledge that the USSR was the only country in Europe reviewing its economy almost entirely from its own resources. He had no answer as to how the requisite accumulation could be ensured; nor did other Soviet leaders. The effort to bolster the villages in combination with rapidly boosting industry was just a matter of words, nothing more.

From the end of 1924 at the latest, the economic institutions began to see the country's industrial lag, particularly with heavy industry, as doing more than just putting the brakes on the Soviet economy-they saw it as a frank danger. The party leadership, which had refused to consider Trotsky for head of the Soviet economy, instead appointed Felix E. Dzerzhinsky, a tough, efficient administrator, as head of the Supreme Soviet of the National Economy (VSNKh). Soon after assuming his post, Dzerzhinsky began to insist that the existing pace of industrial growth would not protect the country from the danger of agrarization. The original figures for 1924-25 counted on 40\% growth. Dzerzhinsky pushed that to $50 \%$ and later to $60-65 \%{ }^{48}$ Since the resources to support such growth were not at hand, Bolsheviks headed by Zinoviev and Kamenev made more determined efforts to tax the 'kulaks', something which inevitably meant revising Rykov's policy. But in the spring of 1925, the villages could still bring to bear strong lobbying pressure, and the proposed change in policy would have the effect of rehabilitating Trotsky's economic proposals. For these reasons, a compromise had to be introduced, a kind of rationalization. Piecework was introduced into industry, and redundant staff was laid off, acts possible because 1925 turned out to be the banner year for the NEP, which allowed those in power to mobilize reserves without drastic impact on the standard of living. On a practical level, Soviet politicians began to wonder if the USSR could get by permanently with no help from abroad and how well the country might do in acquiring its own investment resources. Since no real-world answer was forthcoming, one had to be found on the ideological level. It came in the form of a new 'Marxist guideline', issued by Stalin with support from Bukharin, that stated it was possible to 'build socialism' in a 'single internationally isolated country'.

One may reasonably doubt whether Stalin and Bukharin's opinion was truly Marxist. Marx said socialism would only be able to claim victory after capitalism

47 Rykov, Doklad na III. Vserossijskom s'yezde sovietov, Izvestija, 13.5., 15.4. and 16.4.1925. Dzerzhinsky spoke of $180 \%$ industrial growth in 1927-28 versus 1924-25; it was to have been provided for by domestic resources.

48 Felix E. Dzerzhinsky, Nashe chozjaystvennoye polozheniye, in: Izvestija, 4.12.1924; also Izvestija, 29.1.1925 (Kamenev). 
had exhausted its developmental opportunities, and could do so only in a common effort by developed countries. On this point, Stalin deviated from Marx. To justify the move, he cited Marx's note in the 'Critique of the Gotha Program' of German Social Democracy, which speaks of two levels of socialism. On the first level, socialism falls short of full attainment because it retains the vestiges of prior epochs. This allowed Stalin to separate out the idea of 'socialism' from the level of maturity of society. The main yardstick for socialism was converted into the establishment of a 'dictatorship of the proletariat', in other words, the assumption of power by the Communist Party, abolishing private ownership of the 'means of production' and replacing it with a 'socialized' economic system controlled by a central power. Under this definition, socialism could be considered constructed even with poverty present in society, famine raging, and the governing party using mass terror as a tool for 'socialist construction'. This scholastic exercise, though, did not in fact provide Stalin with a way to ensure a turnaround in industrial development.

This being the case, it is also worthwhile looking at Trotsky's ideas from the same period, in particular his 'Towards Capitalism or Towards Socialism?', put out originally by Pravda and since published in book form in a number of languages. ${ }^{49}$ Trotsky provided a sober estimate of the pace at which USSR industry should grow. He considered the starting point of 6-7\% attained in pre-war Russia to be adequate and presumed this figure could be increased to or three times based upon actual results. He strongly rejected economic autarky, calling for the development of production sectors capable of high levels of production that would be competitive abroad. He thought domestic production could provide from $40 \%$ to $50 \%$ of the machinery and equipment the country needed, adequate in cost terms and permitting an independent national economy to be maintained. Unlike Stalin and Bukharin, Trotsky thought it key that the Soviet economy was the included in the global economic system. He spoke of 'connecting the commodity-based socialist economy to the capitalist economy'. This connection, he opined, could only be established in the context of the global marketplace and must be of a 'commodity nature. ${ }^{50}$ Autarky, he claimed, scatters assets, leading to a loss of momentum and compromised product quality. Trotsky

49 Trotsky L.D., K socializmu ili k kapitalizmu: Moscow, Planovoye chozyaystvo, 1925. Stalin attacked it for the first time at the XV conference of VKS/b in October-November 1926 (XV konferencija VKP/b: Stenograficheskiy otchet Moscow-Leningrad, Gosudarstvennoye izdatel'stvo, 1927, pp. 512-516).

50 Kommunisticheskaya oppozitsiya, ed. Yuri Felshtinsky, Volume 2, Benson Ver., Chalidze Publ. 1988, p. 136. 
thought a reduced pace much more dangerous than the import of machinery and the needed facilities. 'The more varied our economic contacts with countries abroad, the more difficult it becomes for any potential enemy to disrupt it... We can only speed our development on the universal level if we make expert use of the resources ... provided us by the global distribution of work. ${ }^{51}$ Trotsky did what Stalin and Bukharin would not do by publicly considering the possibility that the Soviet 'experiment' might fail. He claimed that if the developed capitalist countries were able to overcome their lengthy crisis and renew their dynamic growth, the USSR would not stand a chance. ${ }^{52}$

Stalin allowed Trotsky to publish his ideas, and did not immediately distance himself from them. He probably did not wish to take sides in the developing conflict that set Trotsky against Zinoviev and Kamenev by attacking Trotsky anew. ${ }^{53}$ Stalin and Trotsky did continue to talk, but the intensity of their discussion was likely toned down because of hopes that the government's policy would see a successful breakthrough development in agriculture, allowing the Soviet economy to leap forward into the modern era. Starting in June 1925, statisticians began to contend in a united voice that crop yields would be above average to the extent they should approach their pre-war levels, with an excess of approximately 600 million puds -9.6 million tons - available for export, prompting sharply increased expectations for foreign trade revenues. The government wanted Soviet grain in the foreign marketplace rapidly, to ensure a good price. But it did not allow for the fact that these estimates are just preliminary, and that Soviet institutions were neither qualified nor flexible enough to manage such exacting demands.

In the end, the crop yields came in far below the estimates. The statistics showed the villages had adequate stocks of grain, but the market did not confirm this. Grain purchases fell behind schedule and Russian grain reached the foreign markets only after a delay. This strongly impacted industrial imports, which fell by up to two-thirds. The government had to rapidly reduce planned industrial construction and put existing work on hold. Light industry also came up short on imported raw materials, with many textile factories restricting or even ceasing operation. This dealt the authority of Rykov's policies and that of the Prime Minister a heavy blow.

51 Ibid, Volume 2, p. 203.

52 Ibid, Volume 2, pp. 141-147.

53 He remembered the recent propositions made by Zinoviev and Kamenev to exclude him from the Central Committee of RKS/b and from the party. 
As far as internal politics, this debacle did not rekindle the conflict between the 'left opposition' and the party leadership, as might have been expected, but rather intensified the discord between Stalin and the duo of Kamenev and Zinoviev. The tension in their relationship persisted through the greater part of 1925 and grew more aggravated in the autumn, when Zinoviev and Kamenev attacked the policy, said to be tolerated by Stalin, of discriminating in favour of kulaks. Someone was also needed to pin the blame on for the recent failure of the purchase and foreign trade policies, and Stalin thereby got the opportunity to distance himself from the party's 'right-wing', grouped around Rykov. The Fourteenth Party Congress was drawing near, opening a window for changes to the party leadership.

This time, Stalin was ready to join battle with Zinoviev and Kamenev, who had been compromised by their relentless push to 'finish with Trotsky'. Stalin held Kamenev responsible for the economic collapse in autumn 1925 because, as Rykov's deputy, he had great influence over economic matters. Stalin did not leave the conflict with Zinoviev and Kamenev to chance. At one of the party conferences that took place in Leningrad and Moscow on the eve of the Fourteenth Congress of RKS/b, Rykov, in attempting to justify the course of government policy, spoke of the causes of the recent economic failure. Speaking in Moscow, he pointed to deficiencies and mistakes made in economic practice, not attempting to conceal the extraordinary damage suffered. To right what had gone wrong, he proposed cutting back on exorbitant plans, with an emphasis on the slogan 'Civic Peace', thinking that this would prevent dissension from breaking out among large groups of inhabitants. As a follow-up measure, he proposed rectifying relationships with the intelligentsia.

Far from being a matter of chance, the internal conflict within the party was provoked by Stalin's apparatchiks, surely not simply from their own motivations. At the Moscow conference, they attacked the resolutions of the Leningrad conference, with Bukharin, who supported Rykov's justification of the government's policy at the same time he vociferously attacked the 'leaders of the Leningrad organization, playing a special role. ${ }^{54}$ There were, he said, two variant interpretations of Lenin's policy, and he concluded with a threat: the congress would determine which interpretation was correct. The Moscow conference issued a resolution based upon this 'criticism', reproaching Leningrad members for serious offenses against Bolshevik policy, provoking the Leningrad leadership to

54 Bukharin also had personal motivation to attack. Zinoviev and Kamenev had publicly attacked his call to peasants encouraging them "not to fear" and to "enrich themselves". 
defend its opinions-likely the main reason for the attack in the first place. Zinoviev, who had reported on the activities of the Central Committee at the previous congress, was chosen to carry out the task at the upcoming party congress. But his report was an act of desperation. The congress was being organized by Stalin's party apparatus, and there was no doubt the Leningrad members would suffer a crushing defeat. But the only alternative would have been silent capitulation with an identical outcome.

Stalin later called the Fourteenth Congress of the VKS/b, at which this took place, the "Congress of Industrialization". But in fact it was the Fourteenth Conference of RKS/b in April of 1925 that decided on industrialization as the basis for party politics. The main purpose of the VKS/b congress in late December 1925 was to settle accounts with Zinoviev and Kamenev who, with Stalin, originally represented the 'Lenin core' of the party leadership. A 'party delegation' set out for Leningrad with the aim of 'purify' the local party organization of Zinoviev supporters. The 'purification' took several weeks and affected seven thousand party functionaries. Sergei M. Kirov, in Stalin's circle of friends, was appointed governor of Leningrad. ${ }^{55}$ but the purification also extended to Moscow, where representatives of the 'new opposition' were ousted from party bodies and from Comintern. In July 1926, Zinoviev and Kamenev were stripped of their Politburo membership and Comintern chairmanship for 'factional activity', leaving Bukharin to lead Comintern. ${ }^{56}$

The literature frequently states that a new duo of leaders, Stalin and Bukharin, emerged from the Fourteenth Congress. But this congress was in fact also aimed at anchoring Stalin's exclusive role as party leader. Bukharin did not acquire additional power in real terms after the congress. Molotov, as Stalin's representative, possess much greater power than did Bukharin, whose influence was tied to the weakened authority of Rykov and from replacing Zinoviev in Comintern, which only increased his influence indirectly.

55 Zinoviev's declaration at the meeting of politburo dated 18.3.1926, Stenogrammy CK RKP/b - CK VKP/b, Volume 1, p. 685.

56 Reimanovi T. a M., Přehled o složení nejvyšších orgánů KSSS, in: Revue dějin socialismu 3/1968, pp. 386-388; also Adibekov, G. M. / Shaknazarova, E. N. / Shiriniia, Organizatsionnaia struktura Kominterna. 1919-1943. Moscow, ROSSPEN 1997. pp. 100-109. Bukharin took Zinoviev's place in the Comintern but was not elected its chairman. 


\section{The NEP Crisis and Suppressing of the Left Opposition}

\section{The Year 1925 and Crush of Soviet Industrial Planing}

The Fourteenth Congress of VKS/b came to an end on New Year's Eve 1925, without having discussed in detail how to overcome the ongoing NEP crisis. Factual solutions were sought only later, with the emphasis instead on making sure the opposition's defeat was lasting. Proposed changes to the economic policy remained within the remit of a commission headed by Rykov, who regarded the crisis as the result of mistaken practical economic measures. He stressed the failure of foreign trade, for which revenues had come in approximately 600 million rubles lower than the estimate, a drop of one-third. In his mind, at moments like this the country was teetering on the edge of bankruptcy. Grain exports were reduced from 782 (originally 1000) million to 600 million puds, and a 200 million pud grain shortage-3.2 million tons-ensued. Industrial goods were lacking, their quality was poor, and selection was limited, prompting little interest among peasants in selling their excess grain.

The government was forced to scale back its original plans. Rykov insisted on rapid industrialization, but at a pace in keeping with the country's capabilities. This scaling back was accompanied by reduced wages, lower social expenditures and less money spent on home construction. ${ }^{57}$ But Rykov defended the government against criticism over the delays in building up industry, stating his preference for developing sectors that would provide economic independence for the country, while hesitating to support an autarkic orientation. He believed that industrialization required expanding economic contact between the USSR and nations abroad, but that over the upcoming two to three years, there would be an inevitable slowdown in the industrial tempo.

The inconsistency in Rykov's proposals stemmed from his wish to maintain the basis of the 1925 developmental strategy, which helped to keep agriculture from stagnating and peasant farmsteads from declining, but did not provide adequately for industrialization. Economic needs continued to be sacrificed as part of a political calculus designed to reinforce the power of Stalin's circle in the

57 Rykov, Khozyaystvennoye i mezhdunarodnoye polozheniye SSSR, 3.3.1926, in: Izvestija, 10.3.1926, and Rykov: Speech at III Soveshchanii zemorganov RSFSR, in: Izvestija, 3.3.1926. 
VKS/b leadership. Cities and villages thereby remained two relatively closed-off economic units. The vicious circle of the Soviet economy remained intact.

But this situation did not seem to be a key factor to Stalin and those who surrounded him. The turn towards more rapid industrialization on the political level had already been taken. The actual needs of the economy, whose mechanisms were fairly opaque to Stalin's circle, were thus emphasized only in proclamations. At the Fourteenth Congress, Stalin achieved victory in a rapid, surprise attack. But he likely doubted whether its impact would be lasting-many influential, intellectually capable people remained in opposition. Emphasizing industrialization seemed to draw Stalin closer to the opposition, but threatened him with discord from the party's 'right wing', which had the sympathies of some governmental and economic actors. ${ }^{58}$ Stalin neither wished to step back from his fight with the opposition nor was he capable of doing so, whether that opposition be Trotsky or Zinoviev and Kamenev. The consequences of the battle could not be undone, and Stalin could do nothing but accommodate a compromise with the party's right wing.

At the centre was not so much the attitude of Rykov and Trotsky, but rather that of Stalin himself. He prioritized power issues without full awareness of the severity of the economic and social problems that plagued the USSR. That his attitudes contributed to unifying the 'left' and 'new' opposition represented by Zinoviev and Kamenev trouble him little, because in the period immediately after the Fourteenth Congress of VKS/b, there seemed to be little resistance within the party to suppressing these two opposition currents and even less resistance from the public. The opposition attempted to challenge the influx of Stalin's apparatchiks into the fundamental party organizations, but even here met their strong resistance..$^{59}$ Opposition leaders including Trotsky soon began holding back from

58 This situation thus led Trotsky to try 'constructive' criticism of Rykov's propositions. He claimed the state of the industry did not allow elimination of the lack of industrial goods and thereby continued to endanger relationships with the peasantry. He reproached Rykov for assuming only the mobilisation of state funds and not private sector funds, whose significance he had clearly underestimated. There are two records of Trotsky's presentation at the plenum of the Central Committee in December 1924 whose content differs: in Kommunisticheskaya oppozitsiya v SSSR, Volume 1, pp. 108-227, second in RGASPI (f. 17, op. 2, e.ch. 220), see: Nashe otechestvo: Opyt politicheskoj istorii, Kuleshow S. V. (eds). Volume 2, Moscow, Terra, 1991, pp. 220-222.

59 Thiese were the basic VKS/b organizations in the Communist Academy, the institution for ideological preparation of higher party cadres and two influential company organizations - the Aviapribor facility in Moscow and Krasnyi putilovec in Leningrad. 
such challenges, relying upon preparations for the party congress, which was to take place in keeping with party statutes before the end of 1926.

The opposition also withdrew because of a warning, probably from Rykov, Tomsky, and Bukharin, that the opposition leaders risked losing their remaining party functions and perhaps being thrown out of the party. The three proposed conditions for an agreement with the opposition to the Politburo in 1926 that the opposition was willing to accept. ${ }^{60}$ The party's right wing thereby clearly revealed it did not wish to remain in close quarters with Stalin and his apparatus. But the party congress which should have been organized at that time ended up being postponed for a year for no stated reason, freeing the party leadership from its obligation to open pre-congress discussions.

This 'amusing' game-with serious consequences for the country's fate-came to an end with the Fifteenth Conference of VKS/b in October-November 1926. Stalin reported on the opposition, blaming Zinoviev and Kamenev for defecting to 'Trotskyism.' ${ }^{\prime 1}$ The conference was also significant on other points because it attempted to knock the wind out of the opposition's sails by approving the economic policy shift towards rapid industrialization. Rykov's proposals for the 1926-27 economic year were encouraging. The value of industrial production was to grow by $42 \%$ versus $1924-25$, and the developmental pace of heavy industry was to overtake that of light industry. Rykov proposed $17-18 \%$ growth for 1926-27, one-fifth of the performance over the previous five-year period. In 1924-26, agricultural production was to increase by $23 \%$, as were grain purchases, ensuring the growth essential for foreign trade revenues. ${ }^{62}$ The decision was made to start a number of large construction projects: Dnieper hydroelectric plants, agricultural equipment facilities in Rostov-on-Don, metallurgical works in Kerch and Krivy Rog, and a metallurgical facility on the border between the Urals and Kazakhstan. Significant funding began to flow in for other projects as well, particularly military production and aviation.

The political solutions proposed by Rykov nevertheless remained mostly 'conservative'. On the one hand, the pace of industrial development had been

60 They obligated it to defend its opinions within a framework designated by the politburo and to distance itself from those Comintern groups that supported it. See Stenogrammy zasedanij politbyuro CK RKP/b-VKP/b, 1923-1938. Ed. Anderson K. M. Moskva, ROSSPEN, 2007. Volume 2,l pp. 345-419.

61 The conference did not replace the congress and its resolutions were subject to the approval of the Central Committee.

62 XV. Konferentsiya vsesoyuznoy Kommunisticheskoy partii / bolshevikov, 26.10.-3.11.1926: Stenograficheskiy otchet. Moscow-Leningrad, Gos. Izdat., 1927, pp. 105-107. 
increased; on the other, a number of breaks to support the growth and modernization of midsize and large peasant farmsteads were left in place, and Rykov thought the peasantry was under adequate pressure to become self-sufficient. The opposition, by contrast, thought the crisis phenomena emanating from the industrial lag represented a pressing problem and believed the gap in living conditions between the great majority of people and the affluent was dangerous. In retrospect, the opposition was probably correct to emphasize the critical nature of the crisis. But it underestimated the consequences of post-revolution changes. There were no significant assets in the country that could be mobilized to meet the needs of industrialization. The threat posed by social upheavals could be mitigated temporarily by increasing the pace of growth in consumer-oriented production over the short-term, or purchasing industrial goods abroad. But both these ways out would lead to reduced investment in heavy industry and energy, and deepen the disparity between the levels of industry and agriculture.

\section{Tautening International Relations and the NEP Crisis}

In the earliest days of 1927, the existing matrix of social relationships was a minefield. But the regime's crisis was set in motion not by internal factors. Rather it was the changes wrought in the USSR's international position and in its relationships, which had been compromised by Stalin's ham-fisted, expansionist foreign policy.

The actual starting point was a series of events in faraway China, where the USSR had tried to build a strong political position in the first part of 1920 . The Kuomintang, China's national revolutionary party, had beckoned the USSR to send political and military consultants to help create local governmental, political, and military structures. The Soviet leadership committed to providing arms for the Kuomintang and training its functionaries in Soviet schools. The plan was for the party to be able to control China over time and secure its independence from 'imperialism', meaning independence from England, the USA, France, and Japan. Plans also called for laying the basis for a new social system that would provide for the lower social strata, and the Soviet consultants held numerous political positions and other positions of power and had control over the actions of Kuomintang political and military leaders. But these plans were as grandiose as they were unreal.

Stalin and Bukharin insisted that the revolution taking place in China was not socialist but national and democratic, urging that Chinese Communists work not independently but as part of Kuomintang. The leading figures in the Soviet opposition did not share this outlook. They insisted that the Chinese 
Communists maintain an independent organization. Stalin and Bukharin were probably closer to the truth about the nature of the revolution, though it was the opposition which was right in practical terms, because their stance allowed for the fact that the Chinese upper strata and the Communists could not share a single platform.

The opposition's prognosis was confirmed when Kuomintang generals led by Chiang Kai-shek marched northward into the Yangtze River basin and took control of a number of important cities-Shanghai, Nanking, Wuchan-as well as a great portion of central China. Coming on industrial metropolises and trade centres where the left wing and the Communists played a leading role, they nevertheless focused their support on the upper and middle social strata, and they made contact with representatives of the Allied powers and their armed forces, particularly the Navy. Their decision was clear. They chose these social strata and the Allies over the left wing and the USSR, brutally suppressing their confederates on the left, who were caught off guard. The Soviet consultants were forced to exit China, and relationships between the USSR and the Kuomintang suffered greatly when an identical turn of events took place in Beijing, headquarters of the official Chinese government, and in territory controlled by various generals. The defeat hit Moscow even harder because it took place during Chiang Kai-shek's march to the north, from which Stalin and Bukharin expected reinforcement of their 'revolutionary alliance' China, and exuberantly celebrated the success of the 'Chinese revolution'. Now, instead of a friendly China, the USSR had to contend with an uncertain, restless border under pressure from China's new rulers and later, from Japan, which wanted to usurp strategically important Manchuria.

To make matters worse, following on the heels of the defeat in China, the Soviet Union's relations with Europe failed. Ties with Germany cooled, as Germany rectified its relationships with the Allies and entered the League of Nations, complicating the situation on the USSR's Western border, where successor states to the czarist Empire felt no love for the USSR but considered it a threat to their existence. Relationships with England and France also mutated. From the time MacDonald's government fell, the USSR had to confront the hard-edged politics of the English Conservatives. The Soviet leadership was unhappy about this reality, and seems to have hoped that the Conservative government would soon be replaced by Labour. For this reason, it attempted to build closer relationships with the Trades Union Congress (TUC) and thereby obtain an opportunity to influence British internal politics. In late spring of 1926, a general strike by British workers was to be used for this purpose. In the miners' strike, the British government stood with employers; the Soviet Union supported the miners. The intention of the leadership was to destabilize England, something which became 
apparent when it still supported the miners despite the attitude of the TUC, an approach which not only worsened relationships with the TUC, but brought the Soviets into conflict with the British government. ${ }^{63}$ It responded to this and to the Soviet role in China by cutting off diplomatic contact with the USSR. ${ }^{64}$ This in turn had a significant impact on the actions of the French government, which seized upon Soviet ambassador Christian Rakovsky's signature of the opposition platform at home in the USSR as a reason to force the Soviets to remove him from his post.

The resulting international tensions led the Soviets to make a number of declarations that revealed the fear of war. Later work by historians frequently considered these declarations feints, made with the aim of rendering impossible any internal political dissension or discussion within Comintern. Although such a calculation on the part of the Soviet leadership cannot be denied, the danger of war was also seriously felt, at least originally. The leadership was confronted with a tense international situation whose consequences were difficult to precisely predict. Chicherin travelled to a number of European cities, determining, to his relief, that the reactions of the European powers did not entail any immediate threat of war or a 'unified front by capitalist countries.65 A significant fact is that years later, when the Soviet Union's military budget had been reduced to a minimum, the Soviet leadership realized that should a war occurred, it would not have the means to protect its territory or its foreign policy interests.

The Soviet leadership quickly shook off its indecisiveness over the possibility that war would break out. It began to argue instead from the premise that the capitalist economy was rising dangerously enough that the USSR might be 'eclipsed' by the more developed countries. There were two facts of substance. First, the leadership realized the USSR could hardly continue to count on extensive aid in the form of loans, credits, concessions, and so on, from abroad as they drew up plans for the economy. Second, it was clear that fear of war not only impacted the leadership, it generated insecurity within the population, as

63 Stenogrammy zasedaniy politbyuro CK RKP/b-VKP/b: 1928-1938, Anderson K. M. (ed.) Vol. 1. p. 817. Molotov called for the slogan: "Down with the Conservative Government, Long Live the Workers' Government".

64 See Carr E.H., Die russische Revolution: Lenin und Stalin 1917-1929, Harmondsworth, Penguin b. 1966, p. 93; Nezhinsky L. N., V interesach naroda ili vopreki im?: Sovietskaya mezhdunarodnaya politika v 1917-1933 godach. Moscow, Nauka, 2004, pp. 251-252.

65 RGASPI, f. 17, op. 2, d. 317 I, Ref. Chicherin and Bukharin at the meeting of the Central Committee of VKS/b 29.7.-9.8.9.8.1927. 
well. This led to an extensive shopping spree that wiped out the consumer goods market, and peasants scaled back grain sales in autumn of 1927. Grain purchases remained well below planned levels, seriously endangering the supply for cities, a problem which could not be overcome using the ordinary means. In late 1927, the need to put pressure on kulaks was discussed in public not just by the opposition, but also by members of Stalin's circle and even the 'right-wing' Bukharin. The basis of the NEP was in danger. In many provincial towns, supplies of goods were cut to a minimum, covering only what was needed for a few days. ${ }^{66}$ The social tensions were heightened by an influx of people into the city, and the government was forced to seriously consider purchasing grain abroad. ${ }^{67}$

\section{The Party and Opposition in 1927. The "Platform" of Opposition}

But that was not the end of it. Starting in spring, internal political tensions grew, and the opposition, which the leadership might well have considered powerless only a short time before, was back. It pulled itself together with the defeat of the Soviet Union's China policy and the dispute with England. In April 1927, Stalin managed to squelch discussion within the Plenum of the Central Committee of $\mathrm{VKS} / \mathrm{b}^{68}$, but he could not do the same within Comintern, where Trotsky took the podium to oppose the party leadership. The Comintern Executive did not side with his criticism of the Soviet leadership, but showed little enthusiasm to endorse the proposal that Trotsky be excluded from the Executive. Representatives of the opposition, though, agreed on joint action and signed 'Declaration 83-ch', reproaching the party leadership for not holding the 1926 conference and proposing that it be organized within three months, preceded by an open, comradely discussion. The signatories to the declaration requested that previously excluded members with an interest to do so be allowed to return to the party.

The protests grew and the party leadership finally turned to the Central Control Commission to request that it condemned Trotsky, Zinoviev, and others for their behaviour. The Commission's meeting was turbulent, the accusations

66 Daniels R. V., Das Gewissen der Revolution: Kommunistische Opposition in der UdSSR. Berlin, Olle und Wolter, 1978 p. 375; Reiman, The Birth of Stalinism: The UDSSR on the Eve of the "Second Revolution", Boomington, Indiana Univ. Press, 1987 pp. 44-45.

67 Pravda, 20.4.1928 (Kalinin M. I.). Purchasing grain abroad did not take place because the price-100 million rubles-would endanger future planned purchases.

68 Politbyuro CK RKP/b-VKP/b i Komintern, 1919-1943: dokumenty, eds. Adibekov G. M. and col. Moskva ROSSPEN, 2004, p. 443. 
against the opposition obscure, and there was evidence of haste. The end result was not an exclusion of the opposition leaders from the party, but rather an agreement that defined a framework in which the opposition could remain. The opposition thus left the discussion not as a defeated party, but rather as a participant in an unequal but still bilateral agreement. ${ }^{69}$ But tensions rose nevertheless when the opposition drew up and submitted its own platform for the upcoming party congress to the Central Committee Secretariat as pre-congress discussion material. It represented an open challenge to the party leadership, and the Secretariat promptly banned its publication or dissemination, inflaming what can only be called a new party crisis.

The content of this platform mandates greater discussion, because knowledge of what it said was severely hampered by the ban and by interpretations thought up during the Stalinist period. In retrospect, it seems a contradictory document compromised by a narrow concept of market relationships and their role in economic and social life in the country, and by the shallow concept of social differentiation and 'class struggle' typical of Bolshevism. Democracy is also conceptualized in a limited way, whether Soviet democracy or democracy within the party, because it was predicated upon the party clinging to its monopoly on power. Limitations also permeated the conceptualization of international relationships and foreign policy, set in place because of negative attitudes to institutions in 'bourgeois society', particularly the concepts of political democracy, political freedoms, and parliamentarism. Accompanying this was a negative attitude to moderate socialist and democratic parties, and to ideologies which did not share the social and political schemata of Bolshevism.

From our current-day vantage point, however, we cannot focus purely on the platform's limits. These indeed mirror the limits of Bolshevism as it existed in that period. We need to examine the proposals made for resolving the issues of the time. In contradiction to the statements of both Stalin and Bukharin, the platform did not aim to terminate the NEP, even less to return to the era of war communism. Its concept of the NEP was in some respects much broader than that of the party leadership. On the one hand, it championed a number of limits in the private economy, but it also left market relationships in place as an important factor in Soviet economic life and as a way of involving the USSR in the international division of labour, something that would allow Soviet producers to produce at a level that allowed them to compete in the international marketplace.

69 Stalin, Sochineniya 10, pp. 3-91; Socialisticheski Vestnik 18/160, 22.9.1927, pp. 13-15. 
The platform insisted that the industrial and energy sectors be developed first, since they formed the basis for the other economic sectors to which they would give rise. Above all, they would right the imbalance between industrial and agricultural production. It was this imbalance that was a fundamental reason for the crisis phenomena that plagued the Soviet economy. In particular, the platform expressly emphasized that development of the socialist establishment would only continue to make sense if it ensured a higher pace of production growth and a higher standard of living than was the case for capitalist countries. It spoke out against the autarky promoted by Stalin and Bukharin, proposing by contrast that the Soviet economy should be included in the international division of labour and thereby save investment costs, achieve high investment levels, and established an environment favourable for the economy's competitiveness.

The platform envisioned that the pressing crisis in the Soviet economy could be resolved by developing the international trade relationships of the USSR and developing those sectors of the economy that would withstand international competition. It recommended a stopgap measure that would make possible the USSR's involvement in the division of labour - a 150 million pud (2.4 million ton) loan of grain from affluent peasants to support the development of foreign trade. This loan is frequently noted in the literature. Its scope was based upon official Soviet statistics that estimated the unused stocks of grain held by peasants were at $800-900$ million puds, about 8.9 million tons. ${ }^{70}$

A key point in the opposition platform centred on criticism of the party's social policy. It charged that the existing implementation of the NEP allowed for the growth of affluent inhabitants, whose power and influence it somewhat overestimated and whom it therefore proposed to tax more to eliminate the advantages given in preceding years. A long-term solution it saw in building modern, state-owned farms equipped with machinery, tools, and agricultural and zoological know-how, and in state loans and the establishment of farming cooperatives. Unlike Stalin and his circle, the opposition did not recommend mass campaigns to force peasants to enter these cooperatives. A set of economic and social measures was proposed whose implementation would allow for a systematic increase in the standard of living for workers and poor village dwellers.

The opposition, of course, called for changes to more than just the economy and social relationships. It recommended radical democratization of the government and national politics, a reduction in the bureaucratic apparatus, an increased

70 See Davies R.- Danilov V., Dialog istorikov, in: Istoriya SSSR, 2/1990, p. 93. 
level of professionalism, and electable executive bodies. ${ }^{71}$ It also stressed the right of republics within the union and national formations to resolve their own issues of substance within their own administrative territory. In its attitude to local nationalists and Russian chauvinists, the platform hearkened back to Lenin's propositions of 1922. In international policy, it recommended the maintenance of peace and the expansion of positive relationships with countries abroad, focusing in particular on economic relationships with the developed countries. In making these recommendations, the opposition was aware of the current state of these relationships and of Soviet foreign policy as a whole, since many political experts with experience abroad who had been stripped of their ability to participate in internal political activity were members.

We are speaking here only of the platform's basic content. We cannot claim with certainty what results might have ensued from implementing its proposals. The most substantial of them were those to do with involving the USSR's economy in the international division of labour, something that Trotsky, as noted above, deemed possible only on the basis of market relationships. Implementing the opposition's proposals thus depended not only on the direction Soviet politics was headed, but also upon the economic and trade policies of the developed European countries and of the United States. In banning the platform, the opportunity for the USSR to develop in line with its proposals was blocked. Instead, preference was given to future autarky and repressive forms of government.

Before the decision was made, though, the opposition had attempted to expand its base and gain more influence within the party and in society. It organized discussions in private venues and apartments. Contemporary reports say sometimes a hundred people or more took part, overflowing onto adjacent ramps and stairways. Trotsky, in his memoirs, says as many as twenty thousand people took part in these discussions in Moscow and Leningrad. ${ }^{72}$ Opposition leaders had likely recognized that in 1926, they had let themselves be boxed in as regards what was 'legal' within the party, and were forced into conflicts with the

71 V.P. Danilov, a significant Russian historian, notes on this issue: "Why do I think Trotsky was on a higher level than Bukharin and other leaders of that time? Because he fought for a democratic regime within the party... Today I conclude that the basic alternative to Stalinism had Trotsky's name on it. Unfortunately, its fate had already been decided by late 1923..." see Davies R.- Danilov V., Dialog istorikov, in: Istorija SSSR 2/1990, p. 93.

72 Trotsky L. D., Moya zhizn': Opyt avtobiografii, tom 2, Moscow, Kniga, 1990. p. 277, identically Columbia University, Rare Book and Manuscript Library, RP-CPSU, box 6, unidentified, Memoir Pavlov pp. 100-147. 
party leadership in which they could not gain any traction to defend themselves effectively. It was a mistake they did not wish to repeat. The opposition leaders could count on their influence in many Moscow and Leningrad organizations, and on the sympathies of some members of the intelligentsia and students. Their supporters were active in Ukraine, Tbilisi, the industrial centres of the Volga Basin, the Urals, and Siberia. ${ }^{73}$ They probably began to believe they had some chance of getting into the party congress, and they intensified their activity and encouraged supporters to march in independent formations with their own banners to celebrate the tenth anniversary of the revolution.

For its part, the party leadership realized any hesitation it showed in reacting to the opposition's moves would complicate the internal political and party situation. But it had both the security forces behind it and an organizational monopoly that allowed it to control the party apparatus and social organizations, as well as the mass media. It began to exert pressure starting in autumn of 1927. Stalin promoted a solution that would render it impossible for the opposition to express itself in public or to take part in the pre-congress discussions or the congress itself. In November 1927, Stalin excluded Trotsky and Zinoviev from the Central Committee. He also broke with the principle that the security forces (GPU) should not interfere in internal party matters. A leading voice on the Central Control Commission was openly unrepentant. Yemelyan Yaroslavsky said in Moscow, 'They reproach us for using the GPU. Yes, we consider the GPU to be a tool of proletarian dictatorship. ${ }^{\text {74 }}$

In December 1927, on the eve of the Fifteenth Party Congress, Zinoviev and Kamenev could no longer withstand Stalin's repressive moves and ceased participating in the opposition. 3258 other people did likewise. It was a demeaning capitulation, one which relieved them of neither guilt nor punishment. Zinoviev and Kamenev were sent into exile outside Moscow. Stalin permitted them to return after some time, but he placed them in subordinate posts where they frequently suffered bullying and humiliation. ${ }^{75}$ Initially, the members of the 'left opposition' and the 'Decists' were braver. Their leaders, including Trotsky, were deported to remote towns and locations inside the USSR. Rank-and-file

73 In November 1927, Yemelyan Yaroslavsky spoke of opposition actions in Moscow, Leningrad, the Urals, Kharkov and in Ukraine (see Izvestiya, 27.11.1927). The foreign press, diplomatic correspondence and memoirs include a larger number of references to opposition activity.

74 Izvestija, 27.11.1927.

75 Yaroslavskiy, Yemelyan: Nikakich kompromisov, in: Pravda, 8.6.1927 Overall, 5755 persons were punished within the party. 
members were imprisoned in camps from which they never returned. And over time, a large portion of the membership of the left opposition finally capitulated. Christian Rakovsky held out the longest, capitulating only in 1934 at the onset of the Great Purge. Trotsky was originally transported to Alma-Ata by the GPU and from there to Odessa in early 1929. There, with his wife and his older, stepson, Lev Sedov, he was forced on board the steamboat 'Ilyich' and transported to Turkey. With this, any alternative means of overcoming the crisis put forth by the 'unified opposition' died. 


\section{The Stalin's "second" Revolution}

\section{The 1928 Crisis and Stalin's Conflict with the Party "Rightists"}

We have dwelt in detail on matters related to Stalin and his inner circle's conflict with the opposition because the dispute was of a strange character. At the time, Stalin's economic policy—setting aside the substantial issue of autarky-came close to the opposition's on several points. Already by 1927, Stalin had probably decided to significantly boost the pace of industrialization. Testimony to this is his decision to implement a number of large industrial construction projects which, at a later point, became the basis of the first five-year plan.

But after the party congress came to a close, the actual start of construction fell prey to Stalin's decision to hide from the congress the failure of the buy-up of grain, which acutely threatened provisioning for cities and industrial development. He did not wish to start a fight with the party's 'Rightists' before the congress and before he could deal with the opposition. The situation which resulted could only be dealt with by extraordinary measures: grain purchases in OctoberDecember 1927 were only half of what they had been in the same period the year before. ${ }^{76}$ As we have noted, in many provincial towns, stocks of supplies covered needs for only a few days.

The crisis of the Soviet economy and the existing system of social relationships came to an immediate head in the early days of 1928. But the underlying issues reached, in fact, much deeper. In 1937, Sergei Maslov, an emigrant, wrote about the impact of demographic factors. Within a comparable area, the USSR's population grew from 139 million in 1914 to 154 million in 1929. But during this same period, the acreage under cultivation for grain decreased by 12.5 million hectares, with per capita yield dropping to $76-77 \%$ of its 1913 levels. This was accompanied by six million more head of cattle, significantly increasing grain consumption. Social tensions increased the influx of people into the cities. It thus became clear that the government could not avoid instituting rationing and considering purchasing grain abroad. ${ }^{77}$

76 Stalin, too, admitted (Sochineniya 11, p. 10) that compared to January 1927, purchases in January 1928 showed a deficit of 128 million Puds (2048 thousand tons).

77 Daniels R. V., Das Gewissen der Revolution: Kommunistische opposition in der Sowjetunion, Berlin, Olle u. Wolter, 1978, p. 375; p. 375; Reiman M., The Birth of Stalinism: The USSR on the Eve of the "Second Revolution", p. 44-45; Maslov S., Kolchoznaya Rossiya, w. p. (Prague?), Krestyanskaya Rossiya, 1937 The data Maslov adopted from the Soviet 
The pace of industrial construction agreed upon brought with it substantial issues. Starting in 1927, construction investment flowed significantly into new, large-capacity facilities, which meant these funds, would remain outside economic circulation for a long period of time. The government, well aware of market instability and the potential for repeated crop failure, decided to ensure economic balance by creating national reserves of grain, fuel, raw materials and foreign currency. In the 1927-28 fiscal year, approximately one billion rubles were removed from circulation. The national budget for that year was planned at 6.5 billion rubles; in the preceding year, it had been 5.1 billion. All this testified to the enormous scope of accumulation of funds. But the ability to ensure these funds would be gathered was hampered by the issues noted above and reflected in the unsuccessful purchase of grain, as well as by the USSR's problematic relationships with England, France, and the USA. Attempts by the Soviet government to get a new loan from Germany also fell flat. ${ }^{78}$ The result was a significant increase in the passive balance of foreign trade and the inability to cover Soviet industry's pressing needs. The government tried to limit the extent of non-production-related and administrative costs, as well as growth in wages and expenditures for social measures, which given the actual standard of living in the Soviet Union was no easy matter. Expenditures targeting housing development were also cut, further worsening its already catastrophic state. The government manipulated tax collection, relied upon income from a restored monopoly for the manufacture and sale of vodka (Rykovka), and even decided to issue an internal loan that further reduced the limited purchasing power of citizens. ${ }^{79}$

From the end of 1926, Stalin's strategy began to target significantly speeding up the industrialization of the USSR. He was pressed to do so by the rapidly worsening imbalance in the market and the peasants' decreasing interest in boosting their farm production, especially the production of grain. These factors remained a force for many years and caused repeated grain purchase crises impossible to circumvent even under the economic concept proposed by Rykov's government. 1927 proved to be a turning point. The peasants' flagging interest in grain coincided with the USSR's deteriorating international standing and

press of the time does not necessarily conform to statistical data available today, however it is the nature of the issue depicted by Maslov that matters. Also Pravda, 20.4.1928 (Kalinin M. I.).

78 DVP Volume 11, pp. 59-66 and ADAP, ser.: 1925-1933, doc. 259, pp. 546-548.

79 Socialisticheski Vestnik, No 13/155 dated 2.7.1927, pp. 5-9 (Yugov). As of 1.3.1927, the internal loan provided 563 million rubles total, 132 million rubles of which was from citizens and the rest from state organizations. 
the internal political crisis. Extraordinary measures promoted by Stalin and his inner circle in early 1928 aimed to resolve the situation using forced purchases of grain from affluent peasants. This policy was implemented using thousands of worker 'activists' and law enforcement personnel sent into the villages. Court rulings and police actions were brought to bear on the 'kulaks'. Peasants with more than 32 tons of stocks were considered speculators. Functionaries who were not adequately severe in implementing these actions were severely punished. ${ }^{80}$ Notes from Stalin's visit to Siberia at the time showed he was not only interested in overcoming the grain purchase crisis, but in permanently changing agricultural production to build a large network of state and collective farms. These were to be of a scope to provide grain for the market at levels which would cover the country's needs in excess of the ability of private farms.

There was a particular urgency during this period to ensure rapid industrialization. ${ }^{81}$ The turn in Stalin's attitude was also motivated by the defeat of both the 'Left' and 'Unified' opposition, whose key representatives were removed from active participation in the country's political life, a decisive step for the fate of Rykov's 'Rightists', who possessed neither the power nor the stamina to resist Stalin and his supporters. Also at stake from the outset were changes to Rykov's government. After the Trotskyites and Lenin's chosen circle of political leaders were removed from political life, Stalin returned to Preobrazensky's 1924 thesis that the villages were to provide the means for jumpstarting industrialization. In Stalin's autocratic hands, this was tantamount to expropriate the peasants' property and the results of their labour.

Upon eliminating the opposition, Stalin quickly distanced himself from Rykov's 'Rightists'. After the Fifteenth Congress of VKS/b, extraordinary measures were implemented behind their backs, and Rykov was unable to comment on them until later. He, like his political circle, expressed a willingness to accept their 'necessity' in retrospect. But in doing so, he presumed they would be a one-off act, not to be repeated. Stalin utilized this willingness on Rykov's part, but he felt no obligation. Already by early March 1928, Vyacheslav M. Molotov, not acting on his own will, savagely attacked Rykov in the Politburo over a draft industrial and financial

80 Danilov V.P./Khlevniuk O. V., Apreskiy plenum 1928 g. (in: Kak lomali NEP: Stenogrammy plenumov (eds) Danilov V.P., Khleniuk O. V., Vatlin A. Ju. CK VKP/B 19281929 gg. Vol. 1, p. 25) indicates that during Molotov's visit to the Urals, which also took place in January 1928, 1157 local functionaries lost their posts and some were subjected to prosecution.

81 Iz istorii kollektivizacii. 1928 g. Pojezdka I. V. Stalina v Sibir. Dokumenty i materialy. In: Izvestija CK KPSS, No 6/1991, pp. 102-116. 
plan for 1928-29 that he considered inadequate. Rykov reacted to the attack by resigning as Premier, but there was no replacement for him at the time, and it was difficult for Stalin to persuade him to carry on in office. ${ }^{82}$

The conflict smouldering between Stalin and Bukharin concerning the nature of Comintern was also telling. The political course Stalin had embarked on was so radical that it blocked any agreement between Communists, Social Democrats, and democratically inclined members of the public on the common fight against fascism to take place in Germany and elsewhere. The danger posed by Nazism in Germany and its ability to hold power over the long-term and violently promote its objectives was underrated; the presumption was that the fall of 'bourgeois democracy' would immediately open the doors to the 'proletarian revolution'. But the Bolshevik Rightists' resistance to Stalin's policies was undermined from the outset by the efforts of Rightist leaders to eschew conflict and retreat 'with no scandal'.

As we have already noted, the USSR's industrial development was not hastened by the rise of small and midsize peasant farmsteads that would require a protracted, significant investment. Trotsky offered a satisfactory solution that would have drawn excess population from the villages, freed space for the growth of large-scale rural production, whether state, cooperative or private, and equipped it with machinery and tools, reducing rural consumption of agricultural production. But this approach had not been implemented in the foregoing years, because it required substantial investment in heavy industry and construction the Soviet government was unable to provide. The conditions under which such an approach would be possible had dissipated by 1922-24, when the USSR failed to support construction using foreign loans, credits, and large private investments from abroad. ${ }^{83}$

Only two possibilities existed for the emerging 1928 crisis. One was Rykov's solution, which attempted to maintain and shape the governmental strategy based upon the NEP that had been used up to that time. Rykov considered the absence of foreign investment a given that Soviet politicians could not change by themselves. Since 1925, the government had strived to boost industrial investment substantially, however, it tried to resolve the 1927-28 crisis by slowing the pace of industrial development. This was to allow the development of closer ties between

82 Danilov/Khlevniuk, Aprel'sky plenum, in Kak lomali NEP, Volume l, pp. 18-19 and Volume 4 p. 55 (Tomsky) and pp. 288-289 (Molotov).

83 The Soviet government is not the only one culpable for this failure. The Allies and particularly the government of Great Britain provided support exclusively to Germany, thereby opening the path to its re-militarization and the Munich Agreement (see later). 
villages and the industrial sectors which were to support agricultural growth. As it turned out, Rykov was willing to content himself with prolonging the implementation deadlines given in the production guidelines for the first five-year plan of 1928-32 by two years. He believed this step would provide the accumulation of funds and the time needed to resolve the problems in the villages.

But Stalin objected that what had not been possible to attain in preceding years would hardly be attainable in upcoming years, and he was convincing to those not sufficiently familiar with the issues. His objection reeked of demagoguery and revealed Stalin's lack of knowledge about economics. Rykov's proposals nevertheless acted as a driving political force, because they put forward a solution. It must be conceded that Stalin and his circle did not fully comprehend the extent of violence that accompanied the implementation of this solution in the villages. But it was Stalin who questioned whether the USSR could successfully develop if small-scale production at the village level persisted. He saw a way out in rapidly constructing state-owned farmsteads and peasant manufacturing cooperatives ${ }^{84}$, but in so doing overlooked an important fact upon which Rykov based his thinking: establishing agricultural cooperatives would not bring material results immediately. They required a long period of consolidation, the introduction of new technology and agricultural and zoological knowledge. This meant a period of years was necessary since, to that date, the Soviet Union had not yet acquired the capacity to provide machinery to villages, and the Soviet educational system could not send the requisite numbers of experts to the villages. In upcoming years, the key reason for constructing state-owned and collective farms was to create tools to increase the quotas for grain purchases in order to provide for the needs of the cities and the development process.

Industrialization took centre stage for both Stalin and other leading Bolsheviks. On this point, they did not differ. But when Stalin proposed industrialization, almost a decade had been lost for its implementation because of his ambition for power. He therefore decided that to postpone industrialism further would only prolong and deepen the USSR's crisis. Changes in the international situation also had to be taken into account. These worsened the USSR's position in Europe and in the Far East. Another critical factor was the consolidation and economic growth in developed capitalist countries. Stalin said, 'In terms of technical and economic development, we must catch up with these countries

84 O rabotach aprel'skogo ob'iedinennogo plenuma CK $i$ CKK, in: Kak lomali NEP, Vol. 1, 407-408; I. V. Stalin, Na chlebnom frontie, in: Stalin, Sochinenija 11, 86-87 a 88-92. 
and overtake them (author's note: the developed countries). Either that or they overrun us. ${ }^{35}$

These aspects of the decision-making process that drove Soviet politics of the era must be explored because they are the only motivation for the excessive haste used in implementing the industrialization policy. Looking in from the outside in mid-1928, it might well have seemed that Rykov was entirely correct to warn against rash action. But the agricultural situation was not improving and the apparatus was getting nervous. The 'extraordinary measures' were rescinded under pressure from Rykov, but violence continued to be used in the villages on an enormous scale. Peasants were losing interest in doing efficient agriculture, and both the areas under cultivation and the numbers of cattle began to drop sharply. In late 1928 and early 1929, grain purchases covered only $61 \%$ of the planned amount. Wheat and rye purchases in particular began to fall. In the 1928-29 fiscal year, only 7.62 million tons of grain were purchased, versus 10.24 million tons the preceding year. ${ }^{86}$ This impacted provisions for cities and indeed the state of the economy as a whole. Work productivity tanked, not to mention the work ethic. Soviet foreign trade, the source of machinery imports for industrial development, was short of grain as a commodity for trade. Large industrial groups and facilities such as Jugostal, Donugol', Azneft', the Ural metals industry and the chemical trusts were all hit the same as everyone else by austerity measures. ${ }^{87}$

Such was the situation in late 1928, but even more decisive was the country's overall condition. The 'Rightists', unaware that their attitude would be key in determining the country's fate, did not act as a unified team. Bukharin was focused on the preparation and proceedings of the Sixth Congress of the Comintern program and let Stalin know he was not eager for a conflict. In autumn 1928, he was on holiday in the South of Russia, able to influence the discussion in Moscow only indirectly. His 'Notes of an Economist', published in Pravda, generated discussion among the urban intelligentsia, but could not replace his presence in Moscow,

85 Stalin, Sochineniya 11, p. 248. Although today these claims made by Stalin may be criticized with justification, it cannot be overlooked that the USSR and Europe were only 10-12 years away from World War II, the same time as had elapsed from the revolution of 1917.

86 Vorwärts, 19.12.1928.

87 Germania, 23.10.1928; Berliner Tagesblatt, 31.10.1928; Kontrolnyje cifry na 1929/1930 gg. assess the situation retrospectively as follows: "1928/1929 started under extraordinarily difficult conditions, enormously disturbed working relationships and organizational ties" (Volume VIII.). 
where Rykov had inadequate support for negotiating the five-year plan. ${ }^{88}$ Nikolai A.Uglanov, the Moscow Secretary and a leading supporter of the 'Rightists', remained out in the rain alone, with Stalin's bureaucratic party apparatus organizing a 'revolt' of regional functionaries against him in Moscow. A similar fate befell M.P. Tomsky, another 'Rightist' and chairman of the Presidium of the All-Union Central Council of Trade Unions - a position to which Stalin wished to appoint his emissary, Lazar M. Kaganovich.

While a number of leading politicians, including Stalin, Rykov, Bukharin, and others were enjoying their holiday in the South, Stalin's apparatchiks, headed by Molotov, were hard at work in Moscow along with VSNCh and Gosplan. Even before they left on holiday Politburo members had discussed the proposed indicative figures for 1928-29 and found them wanting. Stalin and Molotov strived to increase them substantially, arguing that over the preceding two years, the pace of industry had anyway exceeded the tasks set. But they did not consider the resources and opportunities for growth. Their starting point consisted in an effort to rapidly satisfy urgent needs and eliminate economic deficits. ${ }^{89}$ Nor did they seek opportunities to increase the scope of foreign investment; to the contrary, a reduction in the country's dependence on investment from abroad was planned. ${ }^{90}$

The steps taken by Stalin and his apparatchiks imperilled the requirements for balanced planning. Rykov had to interrupt his holiday to return to Moscow, where he was confronted with the outcome of Stalin's pressure. Construction investment of 1.65 billion rubles was anticipated compared to 1.33 billion rubles in 1927-28. The plan counted on rapidly increasing industrial production and electrical production, and expansion of the transportation network. But this was not anchored in the raw iron output, which was at only $79 \%$ of prewar levels. The

88 L. P. Petrovsky in his article "Poslednij Rot front, (in: Oni ne molchali (ed. A. V. Afanasjev), Moscow, Politizdat 1991, p. 186) indicated that the draft of Bukharin article originated in Moscow and was carried to the Caucasus, where Bukharin edited it. Marecky, Bukharin's deputy, ensured the article was published in Pravda with the help of Lenin's sister, Maria Ilyinichna Ulyanova, who worked as Secretary of the Pravda editorial board. He acted without informing Stalin and the members of Politburo. In St. Petersburg, the publication of Bukharin's article was ensured by Petr Petrovsky, the Editor in Chief of Leningrad Pravda. Petrovsky. All these people were Bukharin's supporters and "pupils".

89 V.V. Kuybyshev, Pyatiletniy plan razvitiya promyshlennosti, in: Pravda 25.12.1928; by the same author: Zadachi promyshlennosti v 1928/29 gg. In: Pravda 27.11.1928.

90 V. M. Molotov, K itogam nojabr'skogo plenuma CK VKP/b, in: Pravda, 4.12.1928. 
situation in the construction industry also prevented implementation and light industry, too, suffered from a lack of raw materials.

Planned investment volumes greatly increased the demand for resources to cover the budget: taxes and levies, state loans, a state monopoly on spirits, and the expansion of currency. Taken together, this meant an overall strain on living conditions for the citizenry. Planning bodies, moreover, included funding that could not be provided by the budget's assets: income from reducing its own production costs by $7 \%$, construction costs lowered by $15 \%$, increased work productivity of $17 \%$, and so on. Agriculture was a source of difficulties, as well. Grain harvest levels had remained static since 1926, and we have already noted the increased number of inhabitants and more head of cattle and their consequences. Rykov insisted that agriculture in the country was unwell, but Stalin rejected his objections as being 'defeatist'. The plan thus called for increasing the area under cultivation by $7 \%$ and yields by $3 \%$ (originally $10 \%$ ). ${ }^{91}$ Even had such growth indeed come to pass, it would not have conquered the problem of purchases and provisioning and foreign trade.

The amount and content of guideline figures for 1928-29 was decided at the meeting of the Central Committee of VKS/b in November 1928. Relationships within the politburo were below the freezing point. Rykov and Tomsky referred to the danger of hunger and failure of provisioning for cities. Once again, they submitted their resignations; once again, they were rejected. No one was allowed to exit the Soviet political scene of his own free choice. ${ }^{92}$ As we have noted, Bukharin did not take part in the Plenum. Tomsky and Uglanov, who were fighting for survival, remained silent. Rykov was therefore on his own, outnumbered by his opponents. The only controversial political discussion which took place before the Plenum was a presentation by Moiseĭ Il'ich Frumkin, an important member of the state economic administration who once again spoke of the state of agriculture in the country and the fact that funds allocated for industry exceeded the opportunity for their rational use..$^{93}$

At the Plenum itself, Rykov was the chief opponent. He called attention to the enormous scope of the investment plans, their disproportionate nature and how it endangered their fulfilment. The most serious issues he saw in the lagging

91 Grinko G., Pod znamenem velikikh zadach, in: Pravda, 30.10. and 1.11.1928, also see O kontrolnych cifrach narodnogo khoziajstva na 1928/29 g., in: KPSS v rezoljucijach $i$ rešenijach, Volume II, pp. 405-420.

92 Danilov V.P./ Khlevniuk O. V./ Vatlin A. Ju., Nojabr'skiy plenum, in: Kak lomali NEP, Vol. 3, pp. 16-17.

93 Kak lomali NEP, Vol. 3, pp. 250-256. 
agricultural system and the stagnation of grain production, and he warned against relying upon the rapid development of state-owned and cooperative farms, since it was individual peasant farmsteads which would form the basis of agricultural production for the foreseeable future. To deliver such a report showed his personal courage, but there was no chance that changes to the economic policy would ensue. Members of the Central Committee had been so 'shaped' that they were no longer capable of reasoning rationally.

But these 'shaped' members of the Central Committee did not solely decide the fate of the party's 'Rightists'-Bukharin's manner of opposing Stalin's approach also contributed. In the summer of 1928, Stalin brought Zinoviev and Kamenev back from exile to Moscow, along with other members of the opposition who had given up active dissent. Some in the Rightist camp therefore began to fear these members would support Stalin. But there were no serious grounds for this worry. Zinoviev and Kamenev were no longer taken seriously by the party, but Bukharin made an appointment to meet Kamenev anyway. When he went, he was accompanied by Grigori Ya. Sokolnikov. At the meeting, Bukharin painted in vivid colours the situation in the Politburo, sharing an evaluation of Stalin that was not only harsh but fully expressed his personal aversion to the man. Kamenev made a record 'for Zinoviev'. But a subsequent investigation notes ${ }^{94}$, it was stolen by his personal secretary and used in a leaflet allegedly published by the Trotskyites.

The entire matter was presented to the Politburo in February 1929, and to the joint meeting of the Central Committee and the Central Control Commission of VKS/b. For the first and last time, representatives from both camps, Stalinists and Rightists, exchanged opinions on the state of the party no holds barred. But even now, the Rightists were passive in that they did not request personnel or structural changes and once more tendered their resignations. Stalin's choice was to bind them to 'absolute' support for the 'party's decision', which he thought much more purposeful. In the future, they were not to deviate from the party line-i.e., from Stalin's attitudes. The era in which conflicts of opinion were possible was definitively over, and this was true for closed party forums, as well. ${ }^{95}$ Any visible traces of political or ideological pluralism were erased from the party apparatus in the USSR. Bukharin and Tomsky had already lost their membership in the Politburo by the autumn of 1929. Rykov, bolstered by his years of experience, held out until 1930.

94 See Kak lomali NEP, Vol.. 4, pp. 558-699.

95 Khlevniuk O., Chozjain: Stalin i utverzhenniye stalinskoy diktatury, Moscow, ROSSPEN, 2010, pp. 103-112. 


\section{Stalin, his First Five-Year Plan and Related Issues}

In retrospect, it is not difficult to see what the changes to the Soviet system Stalin enacted in that era meant, in terms of both their content and their impact: a new 'second revolution' to revise the original results of October 1917. Stalin himself later characterized what happened as a 'victory of the socialist system' within the 'sphere of the national economy' and the rise of an exploitation-free society. This new state, he claimed, came about because the elements of capitalism in society were overcome, thereby allowing the 'complete victory of socialism.96

Thus did Stalin see the results of the revolution. In reality, something utterly different took place: society was subjected to a totalitarian system, a unified, hierarchical system of economic and social control in the hands of a centralized bureaucracy reined by the governing party. Within the party, also structured hierarchically, there was the autocratic principle of the supreme 'leader.' There was bureaucratic control of information, of ideology, and of culture, along with the unified control of all basic aspects of foreign policy and economic, social, and cultural relationships.

Within this understanding of the 'revolution', eliminating the private sector took centre stage, along with pluralistic elements present in political life and ideology, as well as in culture and education. For this reason, a great role was played by the 'cultural revolution'. It could not be attained to by using censorship alone and controlling cultural content, but required a unified system of general and professional training and education. Backing this understanding of socialism was the Stalinist interpretation of Marxism-Leninism and the concept of 'socialism within a single country'.

The starting point for implementing the 'revolution' lay in the crises noted above in the post-revolution economic system and post-revolution social relationships. We have zero sympathy for Stalin's projects or the methods by which they were implemented. They elevated mass violence and terror to the level of fundamental tools for social change. But it should not be forgotten that pre-revolutionary Russia lacked all of the economic, social, or educational preconditions a society needs to develop political democracy, a modern market economy, and to radically increase the standard of living. The war and the revolution substantially worsened this already wanting initial state. The lack of maturity of the economic, social, and cultural structure of the country and the multiethnic character of its population,

96 Stalin I., Voprosy leninizma, Issue 11, Moscow, Gospolitizdat 1952, pp. 142-145 and $548-550$. 
multiplied by the country's area and its sparse communications and information network, changing little throughout the 1920s, made fertile ground for the rise of the Stalinist totalitarian system.

Our task is not to focus on industrialization and collectivization in detail. These processes were marked from the outset by Stalin's attempt to press forward with developmental tasks at an excessive pace, an effort which was moderated only in the mid-1930s. His interest in power and social prejudices led Stalin to bypass an opportunity to hasten the USSR's industrial development in the 1920s, and to not make the effort needed to broaden the scope and underline the importance of the economic and cultural relationships USSR had with the developed countries. The excessive number of large unfinished construction projects that resulted from Stalin's rapid development policy tied up significant funding and material assets, deepened the disparities in the development of the Soviet economy, and caused a substantial loss of material assets and harm to the health and lives of the people.

There was also substantial loss of intellectual capacity within society. It centered on the loss of the 'old guard's' expertise as to what was happening abroad, and of the knowledge possessed by the now-rejected members of the opposition. Added to this was the loss of expertise and experience gained by state economic institutions during the 1920s and those who staff them, brought together by Rykov's government. For support, Stalin and his circle looked particularly to members of the party apparatus. They could not replace the lack of knowledge with their own resources.

There was no factual basis for the excessive pace of construction. Whatever the country might have lost by slowing the pace of industrialization, it would have compensated by the experience acquired from the construction process and more effective use of material and human resources. The 'basic variant' of the five-year plan that maintained Rykov's original proposals differed from the later, so-called 'optimum' variant by $20 \%$, equal to an additional year. Rykov wanted to ease the situation for villages, whose economies were sorely in need of consolidation after the violent interference of previous months. But in May 1929, the optimum variant, which for the most part ignored Rykov's proposals, was nevertheless approved. It presumed that the investment of 26.5 billion rubles from 1923-24 until 1927-28, would increase to 64.5 billion rubles in the five-year plan running from 1928-29 through 1932-33. Agricultural production was to increase in value from 16.6 to 25.8 billion rubles, but the prerequisites for this growth existed only on paper. Most investment was being channelled into manufacturing the means of production, to allow the value of industrial production during the five-year period to 
grow up to 3.5 times. ${ }^{97}$ In August 1929, indicators for oil and coal extraction and iron production were almost doubled and the manufacture of locomotive engines, tractors, and means of transport was increased by many multiples. ${ }^{98}$ Investment into agriculture was reduced, as it was for consumer goods production, housing, and cultural development. To add to this, complications and losses attributable to the world economic crisis that started in autumn of 1929 demanded additional mobilization of domestic resources but were not taken into account in time.

But we do not wish to make categorical judgments. The balance of planned development in the USSR did not depend solely on the steps taken by Stalin and his political circle. It also depended upon what the victorious World War I Allies did, particularly Great Britain, France, the USA, and Japan. With the exception of the governments headed by David Lloyd George and J. R. MacDonald in England, and E. Herriot in France, the Allies exerted relentless pressure upon the USSR before seeking opportunities to develop their relationships in a positive vein. Such opportunities were available in the mid-1920s and bore the promise of influencing the course of Soviet politics.

When the world economic crisis broke out in September 1929, it impacted the price of grain. The result was that although Soviet grain exports increased significantly in 1930-31 due to Stalin's policy, the profits made still did not cover imports. This dramatically increased the USSR's debt, which grew from 615 million gold rubles as of 1 October 1929 to 1.4 billion rubles as of 31 December 1931, more than double. The Politburo was forced to make a decision on radically reducing imports, greatly complicating the completion of key construction projects.

But the five-year plan nevertheless represented a step forward, regardless of the unreasonable demands it made and the unjustified material and human losses. It initiated an investment impulse, however distorted, which stood industry on its own feet. 1500 industrial enterprises were built and launched into operation, and in subsequent years, the pace of industrial growth increased, as well, not just for new construction projects, but also because of the launching of projects initiated under the first five-year plan. This led Soviet industrial production to increase by approximately three times from 1928 until 1940, an average of $10 \%$ per year, and large one-off production volumes were implemented by large

97 G. T. Grinko, The Fife-Year Plan of the Soviet Union: A political interpretation. London, Martin Lawrence Limited, 1931, pp. 57-118.

98 KPSS v rezolyutsiyakh i resheniyakh, No. II, p. 457. 
industrial facilities. ${ }^{99}$ The country thus managed to close in on the developed countries to some extent. In spite of this, the already low living standard of the population continued to be exploited as a substantial source of investment. There was an imbalance between investments in industry and the social sphere. ${ }^{100}$ It is estimated that in 1932, the actual wages of Moscow workers amounted to only $53 \%$ of the 1928 level, dropping by almost half over the four-year period. ${ }^{101}$ In summer of 1932, the Politburo had to moderate the course it had set and, as part of the rationing system, drastically decrease bread rations. ${ }^{102}$ This measure, along with supply shortages, brought hunger. In the first half of 1932, mortality rates more than doubled along the lower reaches of the Volga. In the area of Kiev, they increased by $70 \%$ and in Moscow, by one-third. ${ }^{103}$ The situation in Soviet villages was also becoming more complex, with rapid development altering the living conditions of peasants. While Rykov wished to apply economic levers in rural areas, Stalin reached for violence and created an atmosphere of general tension.

The original Bolsheviks had been afraid to use excessive violence and the rural environment; their experience during the 'war communism' era and the 1921 famine was still fresh in their minds. Stalin realized the urgency of reconstructing the villages in the late 1920s, but by then they had already undergone frequent changes. All traces of independent peasant organization disappeared, at both the regional and the local levels. Peasants who resisted were subject to repression, making it unwise to stand out, and affluent peasants learned the futility of excessively enlarging their farms, instead maintaining them at a level which minimized the chance that Soviet organs would label them kulak farms. The governing party controlled the villages via the Soviets, tax and purchasing bodies, and enforcement authorities, and they were able to extract the necessary grain and other produce from them even if the peasants hadn't enough to spare. Change also came to the village elite, which now consisted of former Red Army

99 Davies R. W., Soviet Economic Development from Lenin to Khrushchev, Cambridge 1998, p. 43.

100 For more details, see, e.g.: Sutton Antony, Western technology and Soviet Economic Development 1930 to 1945 . Vol. 2, Stanford 1971.

101 Kuromiya Hiroaki, Stalin's Industrial Revolution. Politics and Workers, 1928-1932. Cambridge 1988, p. 305.

102 See, e.g., Stalin i Kaganovich: Perepiska. 1931-1936 gg. Eds. Khlevniuk O. V. et al. Moscow, ROSSPEN, 2001; Pis'ma I. V. Stalina V. M. Molotovu 1925-1936 gg. Sbornik dokumentov, ed. Kosheleva L. et al. Moscow, 1995.

103 Davies R. W. - Tauger M. B. and Wheatcroft S. G., Stalin, Grain Stocks and the Famine of 1932-1933, Slavic Review, Vol. 54 (1995), No. 3 (Fall), pp. 649-650. 
soldiers and members of Soviet authorities who became permanently established in the villages and knew their way around.

Partially because of the conflict between Stalin, Zinoviev and comment, prior to 1926 Stalin was satisfied with the Rykov government's policies, so long as they consolidated the situation in the villages and brought temporarily shut down capacity back online. But this began to change after the mid-1920s, when it became clear that the policies in force could not remedy the lack of balance in the marketplace and prevent the increasingly grave supply crisis. Stalin's apparatus tapped extraordinary measures and relied on violence from 1928 forward, but this did not lead to a general peasant uprising, as the Bolshevik leadership had feared, but rather to individual instances of terror and passive resistance: cattle were killed, acreage under cultivation was cut. Stalin and his supporters believed they would be able to deal with these issues. ${ }^{104}$

Stalin did not neglect the concerns of the peasant revolts, but was sober in his assessment. By that time, he had already gained extensive experience in using power to resolve problematic points, and he did not believe economic tools could change the way agriculture was done within a short timeframe. The forced purchases of grain helped to deal with the situation in spring 1928, but by that time Stalin had already come to the conclusion that the Soviet economy's problems could not be resolved without replacing the small-scale peasant production that dominated the village with large-scale, modern agricultural production.

\section{Collectivisation of Agriculture and Its Consequences}

During this era, Stalin certainly was not failed by political courage in his conceptualization. This made it possible to turn around development in a number of areas which had seemed impossible to conquer at the time. It was the kind of courage which made him sure of having enough power at hand to prevent peasant uprisings or, if need be, to violently suppress them. But the notion of building cooperative farms to escape the dilemmas faced by Russian and Soviet agriculture was neither Stalin's idea nor Bolshevism's. It sprang from the influence of a number of politicians and academics who had focused on issues related to Russian agriculture. Politically, these people were SRs and liberals, or people close to them ideologically. The original notion held by Stalin's apparatchiks

104 According to Stalin's information from January 1934, the 1929-1933 loss (in millions of individual animals) was: numbers of horses fell from 34 to 16.6 ; cattle from 68.1 to 38.6 ; sheep and goats from 147.2 to 50.6; pigs from 20.6 to 12.2. See I. Stalin, Sochineniya 13, p. 321. 
identified the cooperative with the 'commune', a legacy of the war communism era. It was anticipated that all peasant property would be made collective within the commune.

In the end, three things were key for Stalin: determining what to produce and the scope with which to produce it; making sure the state received the requisite amount of agricultural production; and equipping production units with the needed tools, machinery, and people to get the job done at the necessary level. But these things were frequently done only in retrospect as part of the simple steps used to create the kolkhoz collective farms. On Stalin's initiative, worker 'activists' were sent to the rural areas together with members of the security forces to implement, with local functionaries, forced purchases of grain and agricultural products. Following this, came declarations of the need to replace small-scale, backwards peasant production with an extensive network of production cooperatives and state owned farms, something which took place in succeeding years using repression and the eviction of rebellious peasants.

As early as late 1929, Stalin declared that the 'basic mass of peasants' had turned from the 'capitalist way' to opt for the 'socialist way'. On this basis, he deduced a need to transform the policy of restricting kulaks to one of liquidating them as a class by expropriating their property and evicting them from their home villages. ${ }^{105}$ They thus lost everything, including their real property. The number of farmsteads to be taken was not to exceed $3-5 \%$ of the total number, and was to vary by region and by the number of affluent peasants. In actual practice, this limited the scope of violence only partly. The greater number of kulaks was relocated within their own local areas and individual regions, but they still had to set themselves up in a new location from scratch. Affluent peasants who were seen as part of an 'anti-Soviet element', opposed to collectivization, were evicted to remote regions. In 1930-31, approximately 380,000 peasant families

105 Stalin I. V., Sochineniya, 12, pp. 124-125, 169-170. For more detail see Ivnicky N. A., Kollektivizaciya i raskulachivaniye (nachelo 30-ch godov), Moscow, Magistr, 1996, pp. 10-70. Also: Tragediya sovietskoy derevni. Kollektivizatsiya i raskulachivanie. Dokumenty $i$ materialy 1927-1939. Vol. 2, pp. 126-130. Up to 25,000 worker activists were sent to regions where the "gulag liquidation" was taking place. The number of people active in OGPU increased by 800 and in the OGPU army by 1000. The property confiscated from gulags was given to the cooperatives and local Soviets, but it was also used to pay gulag taxes and obligations. The latest work by Ivnicky "N. I. Golod 1932-1933 godov v SSSR" (Moscow, Sobraniye, 2009, p. 49) indicates that in winter and spring 1930, up to 180,000 activists were sent to villages to support collectivisation and "de-gulaging". 
were moved, amounting to $1,800,000$ persons. The relocations continued in 1932 , with the overall numbers of relocated people increasing to 2.2 million. ${ }^{106}$

These changes touched more than just the kulaks. As we have already noted, the governing party, state administrative bodies, and enforcement authorities also implemented plans to purchase grain, food, and potentially industrial raw materials. These actions also generated resistance, which were painted as antiSoviet by the bodies in power and strictly punished. The collectivization and purchase of grain was thus accompanied by extensive extrajudicial actions, along with sanctions that were formally within the law. Together, a system of mass social and political terror was created as a necessary tool for 'socialist construction' in the villages. From 1929 forward, it was supported by a system of forced labour camps, the infamous Gulag Archipelago. The number of Gulag camps and prisoners grew throughout the entire pre-war period consisting, as of 1 March 1940, of 53 camps, 425 correctional labour colonies, and 50 colonies for juveniles, for a total of approximately 1.67 million prisoners. ${ }^{107}$.

Most Gulag prisoners came from the villages. They had nevertheless a varied background, coming from all strata of Soviet society, including, in addition to peasants, so called 'NEPmen'-private business people, small factory owners, craft workshop owners - along with workers who protested work and accommodation conditions. When Stalin changed his repressive policies in the latter half of the 1930s, something we will address later, the percentage of prisoners coming from the ranks of governing party members grew. Persons accused of counterrevolutionary activities made up from between $26.5 \%$ of the prisoner population in 1934 to $34.5 \%$ in $1939 .{ }^{108}$ Criminals were another important segment of the prison population, significantly influencing the atmosphere of the camps and the prisoners' living conditions. The prisoners were in any event used for the most

106 The data is conflicting. The highest number is quoted by Hildermeier M. (Geschichte der Sowjetunion, 1917-1991: Entstehung und Niedergang des ersten sozialistischen Staates, München, C.H. Beck, 1998. p. 368): 5-6 million people and 1 million out of 25 million farmsteads. Most figures come from the 1930-31 period. The number of relocated, however, must be compared to the number of villages inhabitants: 100.9 million (82.1 \% of inhabitants) in December 1926.

107 Krasilnikov S. A., Rozhdenie Gulaga: diskusii v verkhnikh eshelonakh vlasti. Istorichesky Archiv, 1997, No. 4, pp. 143-144. GULAG - main camp administration. It was created in 1930 within the People's Commissariat for Internal Affairs (NKVD).

108 For more see Zemskov V.N., Spetsposelentsy v SSSR 1930-1960, Moscow, Nauka, 2005, pp. 16-74. 
difficult work under the extreme conditions of the Russian North and in marshy areas during the construction of irrigation canals in Central Asia.

Stalin's claim that the peasants had 'turned toward socialism' in fact reflected only the peasants' attempts to escape the waves of violence, and their hope that expressing agreement with collectivization would permit them to escape it. Residents of villages from which kulaks had been evicted found themselves tempted by the notion that expropriation would expand the assets of the cooperatives they were about to join. But to that point, Stalin's collectivization program had not created the preconditions necessary for effective collective farming and the state could not provide modern equipment to the collectives, or tools, quality cattle, or agricultural and zoological technicians, or mechanical engineers. Some buildings fell into disrepair, arable land deteriorated, and cattle suffered from disease.

In November 1929, the number of farms gathered into kolkhoz cooperatives began a rapid rise, attaining $57 \%$ of the total number of farmsteads in the USSR by March 1930, 58.6\% in Russia. After publication of his article 'Dizzy from Success' that same March, Stalin sharply attacked the lapses that had taken place in establishing the kolkhoz collectives, and their numbers rapidly sank to $21.8 \%$ in the USSR and $20.4 \%$ in Russia before levelling off and then rapidly rising again to attain $55.1 \%$ by July 1931 . Even at their point of deepest decline, then, the kolkhoz collectives accounted for approximately $20 \%$ of the total number of farmsteads and had almost returned to their original presence within six months. This likely says that some peasant farmers were not motivated to join the kolkhoz totally by violence. ${ }^{109}$ One factor was the traditional differentiation of agricultural regions into those that produced and those that consumed agricultural products. The consuming regions did not have the same dependence upon agriculture, nor did they undergo the same pressure to increase performance as did the producing regions. ${ }^{110}$ In central and northern Russia, peasants made extra money by craftwork or left to work in industry. In the South, by contrast, they were bound more securely to grain and food production, which became the centre focus for state and purchasing authorities. In the consuming regions, consolidation into

109 Hildermeier M., Die Geschichte der Sowjetunion, s. 389.

110 In the Moscow and Leningrad regions, the urban population accountedfor up to 50\% of the populace. A high percentage the population in Donbas, Kharkov and Baku in the Transcaucasia was also urban. In other regions of the European section of the USSR, the urban population accounted for $10 \%$ to $20 \%$. See Naseleniye Rossii $v$ XX vieke: Istoricheskie Ocherki (eds.) Polyakov Ju. A., Moscow, ROSSPEN 2000, Vol. 1, pp. 143-147. 
kolkhoz collectives freed a portion of the labour force for industry and craftwork, and was advantageous not only to the state, but benefited a significant section of the village populace, as well.

This, however, directs our attention to another factor in the village situation: the overpopulation of a significant area of the Russian countryside and the relative poverty of Russian villages. Kulak farms in Russia and Ukraine accounted, according to official estimates, for about 2 to $5 \%$ of farms. ${ }^{111}$ But any settlement with two horses and two cows might also be designated 'kulak'. About a third of the farmsteads comprised settlements that, using the Russian benchmark, were poor and failed to provide their owners an adequate livelihood or clothing. The establishment of kolkhoz collectives hence could appear attractive to a number of village dwellers who could now improve their prospects by leaving for the city.

War and the 1921 famine had given rise to a middle-aged generation that tipped the gender balance strongly in favour of women in the Russian villages. Young people between 15 and 19 years of age accounted for approximately half the population. ${ }^{112}$ Many could not find work and lacked personal prospects in the villages. This naturally played an important role in a situation in which industrialization allowed people to leave for the cities and employment in industry came to the fore. The reduced consumption of agricultural production in the villages also was in line with state economic policy. Technical crops were grown in the enormous expanses of northern Russia and Siberia as well as in Central Asia, where cattle farming was developed and natural resources were mined. But making use of this production depended upon developing the consumer goods sector and the consumer-oriented portion of the transport sector, undoubtedly impacting the pace of agricultural development and the nature of collectives and collective farming.

These circumstances naturally influenced the extent and form taken by violence, as well as its relationship to the kolkhoz collectives and state agricultural policy. Near Moscow and Leningrad, in the districts of northwest and central Russia, peasants had adequate opportunities to leave the village or acquire additional earnings in the cities and at construction sites. This was also likely true for the Central Volga Basin, and for a portion of Left-Bank Ukraine. This gave rise to a peculiar geography of violence in the villages, something also true in regions where the purchase of grain and other agricultural products was important to

111 Ivnicky N.A., Golod 1932-1933 godov $v$ SSSR, pp. 60-61. The actual state of gulag farmsteads was estimated at 2.3\%.200,000-250,000 gulag farmsteads were self-liquidated in 1930-1931.

112 Ibid, pp. 154-155. 
the likelihood of cities, for foreign trade, and for funding the five-year plan. In consumption regions, the government implemented its goals by allowing peasants to leave for construction projects and life in the cities. But this sheds no light on the role played by violence during the collectivization and industrialization of the USSR, the extraordinary scope of which made it possible to set in place an extensive directed economy in less than a decade. Because of the violence, traces of pluralism were apparent in the economy and elsewhere in social life only on a scattered basis. This represented a visible change over the 1920s, when violence was extensive but not omnipresent.

The high point of violence in villages came in 1932-33, when it brought extensive famine to areas producing grain for the market. The famine is said to have impacted up to 70 million people, but estimates of the victim numbers differ. Most authors who have researched the tragedy say there were somewhere between 4 million and 8 million casualties. ${ }^{113}$ But these figures are not rock solid. The regime tried to conceal both the extent and the very existence of the famine. In determining its scope after-the-fact, this act of concealment left its mark, as did the later 'bargaining' over the number of victims in an effort to condemn the Stalinist regime or use the numbers to justify a national, Russian, or Ukrainian goals. We may therefore only note that the estimates of victim numbers do not really paint the picture of the monstrous nature of the event and its underlying causes.

\section{The 1932-1933 Famine and Changes in Stalin's Politics}

The key cause of the extraordinary violence and casualties was not collectivization itself so much as it was the efforts we have noted by Stalin and his circle to acquire grain and other agricultural produce in amounts sufficient to implement exorbitant plans for industrialization. The danger of these plans collapsing was real. In fighting to implement them, Stalin and his associates were also fighting for their own political lives. This was probably a vital motivation for Stalin and his supporters to ruthlessly plunder Ukraine and Russian villages between 1929-1933. ${ }^{114} 1932-33$ famine, to be explored in detail later, was also able to occur because Stalin and those around him deliberately ignored the experience

113 The figures indicated by historians vary on the order of millions; figures from internal reports by the leading bodies of that time are often more modest. See Ivnicky N. A., Golod 1932-1933 godov v SSSR, pp. 243-245.

114 Kondrashin, Viktor V., Golod 1932-1933 godov: Tragediya sovietskoy derevni, Moscow, ROSSPEN, 2008, pp. 70-71. 
they had gained from the 1921-22 famine with identical causes. Victims of the new famine were much worse off than their predecessors in 1921-22 had been, but the fact that Stalin and his circle concealed the famine effectively blocked domestic and foreign aid for the victims.

The nature of Stalin's 'second revolution' cannot, then, in any respect be brought into line with Stalin's declarations on 'building socialism' and 'eliminating exploitation'. We have already spoken of the fact that a totalitarian society arose in the USSR that in no way eliminated or moderated the level of oppression, but rather made it into a permanent fixture.

The famine, and the responsibility Stalin and his circle bore for it and the death it brought to millions of people, severely impacted the USSR's development in the 1930s. Today, we may question the statements of historians that the regime managed to completely conceal the 1932-33 famine. The Soviet leadership did manage to suppress news about it and limit the circulation of both private and official correspondence that carried information about it. It was successful in keeping the information from spreading abroad, and it managed to conceal it as well from people who lived in regions hundreds or thousands of kilometres distant from the famine. But it could not hide the knowledge from those who lived in the affected regions and those who lived in neighbouring regions. This amounted to tens of millions of inhabitants. Nor could it keep the information away from a broader group of functionaries in the governing party and state institutions, nor enforcement officers or soldiers deployed in these areas, nor the thousands of activists involved with the kolkhoz collectives and purchasing. We must therefore modify our current ideas about the degree to which the famine was concealed. The regime could not have prevented a relatively broad circle of party members and functionaries, and a wide swath of the citizenry, from knowledge of it, nor keep them from discussing its causes and noting its consequences.

The political repercussions were severe. At the time the famine occurred, the conflict between Stalin, Rykov, and Bukharin over how the first five-year plan was to be conceptualized was still an urgent issue. For many party members and functionaries, the famine was further testimony that Rykov's and Bukharin's objections to Stalin's plans and methods, as well as the objections of the Left, had a basis in fact. They saw Stalin's responsibility for the famine as indubitable, and people originally behind Stalin and his circle, as well as others in the middleaged generation about to take over high-level functions, became hardened in their repudiation of Stalin and those around him.

But tensions had already been present in the party since the 'Rightist deviants' were purged from the leadership. Clear proof was a group that arose in 1930 around Sergei I. Syrcov, appointed by Stalin to head the Russian Federation, and 
Vissarion V. Lominadze, known as Beso, the Secretary of the VKS/b Transcaucasus Bureau and a favourite of Stalin. The circle that formed around these two consisted of middle-aged party members opposed to Stalin's manner of leading the party and to many aspects of his economic policies. ${ }^{115}$

The way Stalin developed his policy of repression testifies to the situation at the time. Until the 1930s, the targets of Stalin's repression were older 'experts' helping to implement governmental policies. Stalin saw them as supporters of Rykov's policy, which he wished to sabotage and accordingly their arrest took on a political dimension, with many accused of preparing a coup. ${ }^{116}$ A number of trials took place at which evidence was brought forward against the so-called Industrial Party, the Menshevik 'Bureau of the Union' and the 'Peasant Party of Work', among others. ${ }^{117}$ The majority of those accused were sentenced to death or to long prison terms as Stalin and his circle tried to intimidate the party by instilling a vision of a broad-based conspiracy of anti-Soviet powers. ${ }^{118}$

More significant changes to Stalin's repressive politics began to take shape in the late 1932 and early 1933, clearly tied to the failure of his economic policy, which had expanded the basis for rebellion within the party. The first in this series of rebellions was that of Martemjan N. Rjutin, former party secretary for the Moscow workers District Presnja, who gathered a small number of members of the 'Union of Marxists-Leninists' and requested that Stalin and his regime be ousted. The 'Union' was denounced. ${ }^{119}$ But this was not the only such instance. Soon on, thirty-eight important members of the 'Bukharin school' were arrested,

115 Pis'ma I. V. Stalina V. M. Molotovu 1925-1936 gg.: Sbornik dokumentov, pp. 188-190; Oni nie molchali, eds. A. V. Afanasiev, 1991, pp. 125-144. The group's existence was denounced, its members stripped of functions and persecuted.

116 Pis'ma I. V. Stalina V.M. Molotovu 1925-1936 gg., pp. 190-191, 220, 222.

117 A substantial role was also played by the "Academic Case" (1929-1931), in which many scientists were accused. In the end, the lawsuit announced against the "Peasant Party of Work" was not followed through. Extensive arrests impacted former officers of the pre-revolution army active in the Red Army. Arrests were also initiated in Ukraine and Belarus targeting the national intelligentsia.

118 Barsenkov A.S./Vdovin A.I., Istoriya Rossii 1917-2004, Moscow, Aspekt-Press 2006, pp. 222-223; Litvin A.L., Sudebny protsess nad nesuschestvuyuschey partiey, in: Men'shevistsky protsess 1931 goda, Moscow, ROSSPEN, 1999, Vol. 1, pp. 4-5.

119 Pis'ma I. V. Stalina V.M. Molotovu 1925-1936 gg., pp. 218, 220. Ryutin conceived two characteristic documents: A letter to party members and a treaty requesting Stalin and his regime be removed. He was sentenced to 10 years in prison and died during the purges in 1930s. For more details see Starkov B. A., Dielo Ryutina, in: Oni ne molchali, 145-178; Khlevniuk O. (Chozjain, 154-156) says Stalin demanded death 
allegedly for organizing and opposition conference, but in reality this was a simple meeting of graduates of party academic institutions. Most were sentenced to imprisonment for various terms. ${ }^{120}$ But this was not the end of it. Three other high-level party functionaries were also denounced: Alexandr P. Smirnov, formerly a Secretary of the Central Committee of VKS/b, Vladimir N. Tolmachev, an RSFSR People's Commissar for the Interior and Nikolay B. Eysmont, People's Commissar for Trade of the USSR. Their sin was to express a lack of satisfaction with Stalin's economic and social policies, for which they were removed from their functions and, after some period, sentenced for 'anti-Soviet activities. ${ }^{121}$

The lively discussion these moves provoked at prominent Moscow universities made clear that what was involved was more than just isolated cases. Some younger and middle-aged party members had serious doubts about Stalin's policies and Stalin felt the impact personally when his wife, Nadezhda Alliluyeva, a student at the Moscow Industrial Academy, committed suicide. ${ }^{122}$ Stalin's interest in bringing 'old guard experts' to trial cooled sharply. ${ }^{123}$ How many party members were alienated from Stalin is not central. What is of consequence is how badly shaken Stalin and his circle were, and that they lost faith that the party would support them, or that mid-level members of the party intelligentsia who had come on board after the revolution would do so. The chasm that stood between Stalin and these party members was filled with the bodies of the millions who had died during the famine, and it could not be erased by punishing rebelling groups or individuals. The death of millions in the famine was not a misdemeanour; Stalin and those around him likely lost faith it would be forgotten and forgiven once time had passed. In consequence, he significantly hardened internal party policy with

for Ryutin at the Politburo. See the draft resolution of the Central Committee dated 2.10.1932 on Ryutin-Slepkov (RGASPI, f. 17 op. 2, Vol. 487, 1. 26-27).

120 Barsenkov/ Vdovin, Istoria Rossii, 213, more details Rogovin Vadim, Vlast ${ }^{`}$ i oppozitsiia, pp. 289-291.

121 Nashe otechestvo, Vol. 2, 302-303. The case was discussed at the meeting of the Central Committee of VKS/b 7-12.1.1933. A statement alleged to have been made by Eismont was pointed: A choice must be made between Stalin and the peasant uprising. RGASPIf. 17, op. 2, d. 514 v. II.

122 The death of Nadezhda Alliluyeva has been interpreted in various way in the literature. Some authors attribute it to the political tensions of the era, others to family tensions. Supporters of the first version say Alliluyeva committed suicide in reaction to Stalin's policies or to the response his policies generated.

123 The last in this succession of lawsuits struck employees of the British company MetroWickers in spring of 1933. 
a new purge in 1932-33 that saw 450,000 members thrown out of the party. ${ }^{124}$ This represented a clear turning point in Stalin's reaction to what was going on in the country, and its consequences became clear only after some time. Stalin lost interest in repressing the 'counterrevolutionary' stratum of the 'old intelligentsia'. His focal point became manifestations of internal party disagreements with his policies. Although he continued to hold Trotsky, Zinoviev, and Kamenev, as well as Rykov and Bukharin, responsible for the rebellion, he now interpreted efforts to remove him as terrorist acts. ${ }^{125}$

This shift in ideology must be explored in the context of the modern Russian political tradition, which treated the assassination of government officials as an accepted fact. Party leaders initially backed away from the notion, probably in fear for their own lives, and thus, in late 1932, Stalin was not able to get capital punishment approved for party members. ${ }^{126} \mathrm{He}$ did manage to get approval for the party purge that we have already noted. Expulsion from the party should not be underestimated as a punishment, because once expelled, former party members were no longer protected from the OGPU. These purges therefore became an important step on the road to the tragedy of the late $1930 \mathrm{~s}^{127}$

A profound issue came into being as part of this. The party was dominated by a restricted group of functionaries who knew each other. But those who had been expelled created a significant force from Stalin's point of view. They were used to organizing, they had contacts within the party, and they had their own hierarchy of political authority comprising the formerly popular party leaders. In 1932, they were joined by a large number of educated functionaries of the middleaged generation who had already begun working in high-level posts within the party and the state apparatus, and in the press and social science institutions. This was, therefore, a political grouping which could significantly impact both the members and the leaders of the party, felt not only at party headquarters but also within the republics and the regions, where opposition attitudes often

124 See the resolution cited on the Ryutin and Slepkov cases.

125 A letter Trotsky wrote to the CIK of the USSR on 1.3.1932, in which he reacted to being deprived of his citizenship, was misused: 'Stalin has led us into a blind alley... Lenin's pressing advice must finally be fulfilled: to eliminate Stalin.' Trotsky, Lev, Prestupleniya Stalina, Moscow, Izdat. Gumanitarnoy literatury, 1994, p. 194.

126 See the letter from Stalin and Zhdanov to Kaganovich and Molotov dated 25.9.1936. In: Stalin i Kaganovich:Perepiska, 682-683.

127 Sovietskoye obshchestvo: vozniknoveniye i razvitiye, istorichesky final, ed. Ju. N. Afanasjev, Moscow, RGGU, 1997, 126 and 132; Khlevniuk O. V., Politbyuro: mechanizmy politicheskoy vlasti, p. 62. 
merged with national interests and the interests of regional structures. During the 1932-33 party purge, party secretaries in a number of republics and regions were ousted, likely because Stalin wished to prevent any political force capable of endangering his leadership from forming. ${ }^{128}$ It was at that time he probably began to consider creating tools to punish party members on a mass basis. In a 1936 letter to Molotov and Kaganovich, frequently cited in the literature, Stalin and Zhdanov stated the acts of repression had come four years too late, making reference to $1932 .{ }^{129}$ It was then that some in the party leadership had been able to head off the notion of putting party members to death. But in allowing party members to be imprisoned commonly for political offenses, the door to severe punishments had already been opened.

128 At the Plenum of the Central Committee in February and March 1937, Stalin labelled the origin of friendly groups of functionaries an anti-party phenomenon: "What does it mean when I bring a whole group of friends with me... It means you have gained a certain independence from local organizations and, if you wish, a certain independence from the Central Committee." Voprosy istorii, 1995, No. 10, p. 13.

129 Stalin i Kaganovich: Perepiska. 1931-1936 gg. (Ed. Khlevniuk O. V.), pp. 682-683. 


\section{Stalin's "Soft Course" and the Soviet 1930s Phenomenon}

\section{The Stalin's new Soviet Society}

The new phase in internal party development was conditioned by the consolidation taking place in the country. Stalin and his circle were likely aware of his critical nature, and that it could not be resolved using force. So they decided to first alter their economic and social policies in what Oleg Khlevniuk described as a 'moderate turn.' ${ }^{130}$ This entailed terminating the first five-year plan and cooling the social situation down. It is easy to describe the steps that underlay this turn. The first came in January 1933, when the forced purchase of grain was abolished and an 'agricultural tax' was renewed. Kolkhoz collectives peasants were once again allowed to sell their 'excess' stock in the market. This was accompanied in May 1933 by an easy of repressive acts; the punishment of peasants for minor theft (the 'Tassel Act') was repealed; more than 90,000 court rulings were vacated; and 37,000 prisoners were given an early release. Two years later, additional changes came when peasants sentenced to five years in prison had their sentences erased, benefiting up to 560,000 people. 1935 also saw the release of functionaries sentenced for 'sabotaging' the collection of grain levies in 1932-34. In May 1934, some displaced kulaks received limited civil rights and, in January 1935, the right to vote. ${ }^{131}$ Younger members of these families were allowed to study, even at university. The economic situation of the peasants also changed. Machinery and tractor stations were set up to mediate an influx of modern machinery in the agricultural production regions. Kolkhoz members were allowed to farm their own crofts and to own small animals and a cow. ${ }^{132}$ Thus were the ranks of peasants, who had suffered under Stalin's previous policy reduced. These measures did not enrich Soviet villages, nor did they undo the damage of collectivization and forced grain purchases, but they did raise them from the level to which they had sunk under forced collectivization.

Changes also occurred in the cities, where Stalin himself had forced planning institutions to adopt extreme ideas. The revision of these notions allowed funding to be released that was tied to uncompleted construction projects. It also

130 A.Khlevniuk O., Chozjajin: Stalin i utverzhdenije stalinskoj diktatury, p. 177.

131 Barsenkov/Vdovin A., Istoriya Rossii, p. 231.

132 Khlevniuk O., Chozjajin: Stalin i utverzhdenniye stalinskoy diktatury, pp. 179-180. 
opened the way for attempts to ameliorate the disproportion borne of Stalin's effort to immoderately intensify the developmental pace. ${ }^{133}$ The planned pace of development remained fairly high in spite of this at $16.5 \%$ to $18.5 \%$ per year, still not enough for the balanced development of agriculture and supplies for the citizenry. ${ }^{134}$ The reason for this was that Soviet development was impacted ever more by the escalating conflicts in Europe that accompanied the rise of Nazi Germany and the expansionist policies of the Japanese in the Far East, forcing the leadership to increase spending on the armed forces and military production. This maintained an even deepened the existing disproportion, something which was reflected in the difficult living conditions in the USSR.

The cities did, however, experience a level of relief. The government abolished the rations introduced in 1928-29, ${ }^{135}$ and then it took advantage of the change to introduce a system of task-based and qualification-based salaries and wage differentiation. Party bodies initiated a 'model worker' movement, aimed at increasing worker performance, resulting in greater differentiation within the blue-collar and white-collar environments. Housing starts grew, with a percentage of workers leaving wooden houses in favour of brick homes that did not necessarily offer a significant improvement in housing quality, but did bring greater stability and offered better amenities. Overall, buildings were outfitted in a substandard way. An effort by state and communal institutions to construct separate social and cultural facilities was intended to make up for this, improving the living standard by providing public spas, nursery schools, kindergartens, and public catering facilities. Unions, meanwhile, organized factory clubs and interest-based clubs, stadiums and convalescent homes were constructed, all offering opportunities for spending leisure time. Healthcare services for the population were also increased.

Construction also began of higher-quality housing, but it was chiefly for the privileged-for top economic staffers, high functionaries and officials, military and security officers, professionals with qualifications and 'model workers'. Downtown districts were also reconstructed as examples of socialist housing of the future. Especially massive was the reconstruction of Moscow and the building of the underground, the construction project of the century for the USSR in

133 Nashe otechestvo, Vol. 2, pp. 272-273; KPSS $v$ v rezolyutsyakh i resheniyakh, Vol. II, pp. 747-763.

134 KPSS $v$ v rezolyutsyakh i resheniyakh, Vol. II, pp. 747 and 883, official information on the plan and its fulfilment (in parentheses); For details see Khlevniuk O., Politbyuro:Mekhanizmy politicheskoy vlasti, Moscow, ROSSPEN, 1996 pp. 134-139.

135 Khlevniuk O., Chozjajin: Stalin i utverzhenniye stalinskoy diktatury, pp. 220-221. 
that period. But construction also took place in Leningrad, Kiev, Kharkov, and Tbilisi, and a number of new towns came into being. Hence it seemed that, in exchange for the extraordinary suffering of the victims, a turning point occurred which saw the country launch off on a path of rapid transformation into an industrial power. By February 1934, at the Seventeenth Congress of VKS/b, which approved the second five-year plan, Stalin could claim that its fulfilment would make the USSR into a technologically, economically independent country with developed technology. ${ }^{136}$

We have already spoken of how Stalin's attitude to the 'old intelligentsia' changed. On the one hand, he persisted in his usual rhetoric of class struggle, but he also wished to calm the situation down. This has prompted the historiographical literature of the past decade to trend towards the notion that Stalin's changes in attitude were caused by his leaning towards Russian national ideology, supported by the concept of 'socialism in a single country'. But we find another aspect of Stalin's thinking noteworthy. The Bolsheviks had seized power as a minority, their will forced upon majority society. This made them feel that they were in a state of siege within their own country that limited them both economically and in terms of their political power. The 1928-33 crisis was a turning point whose nature was defined not so much by Stalin's victory over his party opponents, but by the changes within society that had strongly limited and disrupted the remaining traces of private ownership and thereby savaged the economic independence of the citizenry. Thus could Stalin speak of the upcoming liquidation of the remaining 'exploitative classes'. In the future, society was to comprise two 'friendly' classes: workers and kolkhoz peasants. To these, Stalin appended the lower and middle strata of working intelligentsia. He remained silent on the bureaucracy and on the leading political stratum as a special body outside of society. The Bolsheviks had traditionally spoken of bureaucracy only as a despicable method for controlling work. ${ }^{137}$

This concept of Stalin's allowed the Bolsheviks-in theory if not in fact-to leave their 'besieged fortress' behind them and try to take on a new role as a leading force throughout society. The importance of this change, however, was not recognized immediately nor fully. It first manifested itself in the country's cultural and literary life, which had been starkly restricted by the Bolsheviks' 'fortress thinking' of the 1920s, which placed its focus on fighting so-called petty bourgeois ideology among 'fellow travellers', including most well-known artists,

136 KPSS v rezolyutsiyakh i resheniyakh, Vol. II, p. 764.

137 Ibid, pp. 364-375. 
who were members of organizations that either partially or entirely rejected the regime. The supporters of this fortress thinking, the so-called RAPPists ${ }^{138}$, made a racket in the late 1920s and early 1930s about 'purifying' the writers' community. But given what was happening in 1932, the last thing the party-meaning Stalin and his circle-would wish for was a conflict with the literary public. The party leadership thus had no choice but to agree on reconstructing literary and artistic organizations and unifying them, which simultaneously ended the existence of RAPP. ${ }^{139}$ This meant the party lost its 'own' proletariat writers' and artists' organizations. But it gained the opportunity to become a leading power within the arts overall. The resolutions that liquidated RAPP and other proletariat art organizations did not in any way end the party's supervision of artists. New art associations were forced to adopt socialist realism as a creative template, amounting most of all to requirement to depict 'Soviet reality' positively, and to make sure that art remained 'people's art', accessible to the masses. ${ }^{140}$

What this demonstrated was that the VKS/b leadership was changing its image, wishing to act as a centre of power that expressed the interests of 'society at large'. Stalin's subsequent emphasis on the positive nature of Soviet and Russian patriotism, supported by the renewed teaching of history, particularly Russian history, at secondary schools and universities, was an outgrowth of this shift. ${ }^{141}$ A new political formula had arisen that justified the Soviet state conceptually not as communist or Bolshevik, but rather as a society-wide institution. The culmination came two years later with the adoption of a new Soviet constitution that made clear how self-confident Stalin's leadership had become. The leadership had recovered after the failures of earlier years, and began talking about party policies that expressed the interests of the entirety of the 'Soviet people.' ${ }^{142}$

138 A term created from the name Rossijskaia associacia proletarskich pisateley (RAPP).

139 "Schastie literatury": gosudarstvo i pisateli, 1925-1938: Dokumenty. Babichenko D. L. (Ed.) Moskva, ROSSPEN, 1997. pp. 130-131.

140 For more details see, Geller M. / Nekrich A., Utopia u vlasti, Istoria Sovietskogo Soyuza s 1917 goda do nashich dney: London, Overseas Publications Interchange Ldt, 1986 p. 286-290; Korzhichina T. P., Izvol'te byt' blagonadezhny! Moscow, RGGU, 1997, pp. $281-283$.

141 For more detail, see: Kratkiy kurs istorii SSSR, eds Shestakov A. V., Kudriashov S.. Moscow, Vestnik arkhiva Prezidenta Rossiyskoy federatsii, 2008.

142 KPSS v rezolyutsiyakh i resheniyakh, Vol. II, p. 763; O. Khlevniuk, Chozjajin: Stalin i utverzhdenije stalinskoj diktatury, pp. 224-225. This was accompanied by an attempt on the part of the leadership to create a new image for the security forces. OGPU merged with the People's Commissariat for Internal Affairs (NKVD). 
Gestures of reconciliation seem to have multiplied within the governing party, as well. As noted above, after a year's exile, Zinoviev and Kamenev returned to Moscow along with Preobrazhensky, a Trotskyite who declared his loyalty to the Stalinist leadership. Party membership was returned to many members of the opposition, some of whom were even invited to speak at the Seventeenth Party Congress. Even members who had been adamant in their support of Trotsky, such as Rakovsky, were swayed. Resistance against Stalin's policies had lost its force.

These steps by the leadership had an impact on the mood of many of the USSR's citizens, who had just emerged from the difficult transitional years. Below, we will discuss the policy of mass murder of the post-revolution political and social elites that was rooted in the developments of these years separately in great detail. This policy was behind much of what counted as cultural and social phenomena in the 1930s, the specifics of which may not be reduced to Stalin's push for a 'course of moderation', or to the campaign of terrorism against the new upper echelon of society. The Soviet Union of the 1930s was remembered by those who lived through that decade, as well as subsequent generations, not only for its brutal, homicidal reality, but also as a time of penetrating change. The USSR had undergone the radical reconstruction of its social life, something which reshaped it and changed the fate of most of the country's citizens. Change this radical and this deep-rooted has never taken place in any country free of charge. It requires sacrifice. The chief question is whether the loss suffered by individuals and society in the name of such radical change and their sacrifice is adequately balanced by the benefits generated. The seed of the radical change that took place in the USSR was ensconced in the deep economic and social crisis and the failure to address it in time, a failure which imparted an enormous sense of urgency and gave rise to spontaneous dynamics. Together, these factors and Stalin's rhetoric resulted in extraordinary loss of life and material assets, permanently impacting the governmental and social system of the USSR.

We have already noted that pre-revolutionary Russia entered the modern era with an immature social, economic and cultural base and the consequences and manifestations of this had not been overcome by the 1917 revolution and the world and civil wars-in fact, oftentimes the problems had deepened. With the internal political conflicts and the accompanying purges that plagued the leadership of the USSR, power shifted over time increasingly into the hands of a second and third wave of politicians who lack the intellectual, professional and moral qualifications needed to resolve complex economic and social issues. Stalin stood out primarily because of his ability to handle power, and because of his brutality and intransigence. All of what has been said above applied to him, along with a total lack of political culture and the absence of any social or moral 
scruples. He did find a way out of the crisis of the late 1920s and early 1930s, but only at the cost of enormous losses of both material assets and human lives.

In the late 1920s and early 1930s, the preconditions for successfully resolving the economic and social issues at hand were sorely lacking. The result was a solution that was improvisatory in nature and brutally enforced without regard for the victims. In spite of this, a real social situation was being addressed, a resolution characterized not only by enormous sacrifice but by drastic changes to the material and social conditions of life such as Russians had never experienced before, perhaps except at the time of Peter I. Millions of people left behind their former lives in the remote villages of Russia, Ukraine, Belarus, Transcaucasus and elsewhere, places where no event of note had ever occurred. They arrived in the cities and at construction sites, and they took part in construction projects that, in the course of one or two generations, radically changed the face of the country. ${ }^{143}$ Their work in new companies was exhausting, but from their viewpoint also dramatic and meaningful: they acquired new qualifications, they got a basic general education. Their homes were undignified and their work inadequately remunerated, but they were striving for something and, as happens during times of revolutionary change, they could see the fruits of their efforts. For readers today, it is difficult to imagine the miracle this seemed through their eyes. The USSR had come into being and taken root at a time of deep global economic crisis, a crisis which saw existential conditions in the Western countries plummet, and which prompted some from those countries to travel to the USSR in worker delegations to view first-hand this iconoclastic miracle. The visitors also included leading figures of public life and culture and not all were communists. Although criticism was often voiced, their opinion was in no way uniformly negative.

143 The construction projects included structures such as the Turksib Railway (1930), connecting the European section of the USSR with Siberia, the Dnieper dam and the hydraulic power plant Dnieprogres (1932), a metal works in Zaporozhye and Donbas, "Magnitka" - a metallurgic base of the Urals and the neighbouring Kuznetsk coal basin and "Uralmash" (1933) the machinery giant that created a new industrial region. Later, it was the decisive factor in the outcome of World War II. Other projects included agricultural engineering facilities in Rostov-on-Don (1930), Stalingrad (1930), Kharkov (1931), and Chelyabinsk (1933), automobile plants in Moscow (1931) and N. Novgorod (1932), machinery plants in Leningrad and the surrounding region, the 'youth town' of Komsomolsk in Amur and many others. 
This naturally filtered through to the people of the Soviet Union at that time. In spite of their sacrifice and their suffering, they acquired more life experience, both personal and professional, than had the many generations before them, and these years left a significant mark on Soviet literature of the era, and on its film, art, theatre, and music that continues to attract cultural consumers to this day. This was part of the phenomena of the Soviet 1930s, one which-at least temporarily - was often able to drown out the suffering that was present everywhere. Even today, it cannot be reduced to simple strategic manoeuvring and the crimes of its brutal dictator.

Developments in the USSR in the 1930s led to a great breakthrough with regard to living conditions in a society that still felt so strongly the impact of the Middle Ages. But because of this impact, the breakthrough did not extend to the country's political, social, or spiritual life. The radical changes of the 1930s thus gave rise not to a society of free people, but to a totalitarian state that was doctrinally based and curtailed the rights of its citizens. But the feeling of change and that the country had elevated itself nevertheless provided Stalin support and his policies-policies that not only helped, but also enormously hurt, the country and its society for an extended period.

\section{Kirov's Murder and the Turning Point in Stalin's Domestic Policy}

In late 1934, the USSR seemed to be positioned at the threshold of the great leap forward, one which would transform it into a modern industrial country. Hardly anyone anticipated the cruel twist which was about to appear. In a draft presented earlier in the year, the year the Seventeenth Congress of the VKS/b was held, it was anticipated industrial production would increase 2.1 times in the new, second five-year plan. The pace of production had been somewhat toned down, but construction started under the first five-year plan was to be completed, freeing funds currently locked in a still-unfinished projects. The estimated production of Soviet industry from 1928-1940 thus grew approximately three times. An ambitious but unrealistic goal was set for agriculture, where production was to double and grain production was to increase. Construction of social facilities and housing was targeted for expansion. In transportation, efforts to expand and modernize the railway network already underway were to be complemented by the construction of river transport facilities, roadways, and development of the aviation industry.

Measured in terms of its results, the second five-year plan turned out not to be particularly realistic. About $70 \%$ of its targets were met, with annual production 
increments oscillating around $14.5 \%{ }^{144}$ But these results were impacted by the increased development of the armaments industry starting in 1932, which added up to a total of 745 million rubles. ${ }^{145}$ The fast pace of development became a significant component in Soviet economic growth but limited expansion of social expenditures and held down the population's standard of living. ${ }^{146}$ From $1926-$ 1939, the population of the USSR increased by 22.7 million people, 17 million in the Russian Federation. ${ }^{147}$ From 1928 until 1940, the number of blue-collar and white-collar workers in the USSR rose from approximately 13 million to 33 million. New job takers had to acquire both new working habits and a new lifestyle, and the poorer conditions and feelings of dislocation often led to alcoholism, demoralization, and mass crime. ${ }^{148}$ But there were positives as well. Unemployment was eliminated by industrial development. The employment of women rose importantly, with their share in the number of those employed at $24 \%$ in 1928 and $39 \%$ by 1940 . Family incomes expanded, and life in the cities provided more opportunities for access to culture. But the prospects for defending political and social rights remained dim, and the state was virtually the only employer.

In the villages, however, things were much more complicated. At the end of the initial five-year plan, up to 15 million peasant farms were associated in approximately 200 thousand kolkhoz collectives, $62 \%$ of the total. Added to this were 4500 state owned farms that primarily employed peasants. ${ }^{149}$ The villages underwent cataclysmic change when around 20 million people, particularly young people, left for the cities, meaning less food was required to feed them in the villages at the same time their production for the market was increased. In the villages, the production facilities were enhanced by the development of

144 KPSS v rezolyutsyakh, Vol. II, pp. 747-760; Gregory, "Politicheskaya ekonomiya sotsializma”, p. 154.

145 Ibid, p. 585. (A total of 745 million Rubles).

146 See, e.g., Stalin i Kaganovich: Perepiska. 1931-1936 gg. Khlevnjuk O. V. et al. (Eds.), Moscow; Stalinskoye Politbyuro v 30-e gody. Ed. O. V. Khlevnjuk et al. Moscow, AIRO-XX, 1995; Pis'ma I. V. Stalina V. M. Molotovu 1925-1936 gg. Sbornik dokumentov.

147 Naseleniye Rossii v XX veke, sv. 1, 230.

148 For details, see Meerovich Mark, Nakazaniye zhilishchem: Zhilishchnaya politika $v$ SSSR kak sredstvo upravleniya ljud'mi 1917-1937, Mosscow, ROSSPEN, 2008; Lebina N. B., Povsednevnaya zhizn' sovietskogo goroda 1920-1930 gody. S. Peterburg, Letnij sad, 1999.

149 Hildermeier M., Geschichte der Sowjetunion, p. 489, indicates the following share of private farmsteads in kolkhozes: $1934-71.4 \%$; $1935-82.3 \%$; in Jun' $1936-90.5 \%$ and two years later $93.5 \%$. 
machinery and tractor stations that eased access to powerful agricultural technology and disrupted the production structure and village lifestyle that had been common to that point. But life in the kolkhoz nevertheless mirrored much of what had framed the peasant lifestyle under the old regime, when the village produced under the supervision of the landed nobility. Preference had been given to working on the lord's fields, and peasants were restricted in their movements. The kolkhoz and those who worked on it were likewise confined to do so within the limits designated by the state. ${ }^{150}$ The living conditions in villages stabilized from 1933 onward, but no element of 'socialist social structure' came into being with the rise of the kolkhoz collectives.

In spite of its frequently revolutionary changes and their impact on the country and its inhabitants, prior to World War II, the USSR remained only at the threshold of transformation into a modern industrial superpower. But it seemed that the path the country had set out on would bring about rapid change, humanizing and democratizing Soviet life and increasing the living standard and cultural level of the people. As early as 1934, though, a radical act thwarted this potential. On December 1 of that year, Leonid Nikolayev, a former party member and functionaries, murdered Sergei M.Kirov, the party secretary, by shooting him in the neck execution style.

The circumstances of the murder have not been completely explained to this day. Most researchers have come to the conclusion that it was the act of someone who was socially and personally adrift. ${ }^{151}$ Kirov was one of Stalin's friends. ${ }^{152} \mathrm{He}$ had been appointed Secretary of the Central Committee at the Seventeenth Congress of the VKS/b and was about to begin work in Moscow. It is no wonder that Stalin interpreted the murder as a political act. But the actions he took in consequence are noteworthy. Immediately after the killing, Stalin dictated his famous decree against terrorism to the Politburo. State-sponsored terror was legalized; executions were permitted without due process. ${ }^{153}$ From the outset, the decree

150 see Maslov S., Kolchoznaya Rossiya, Chapter VII: Chto takoe kolhoz, pp. 129-157.

151 Zhukov Yu., Inoy Stalin:Politicheskiye reformy v SSSR v 1933-1937 gg., Moscow, Vagrius, 2003. pp. 83-99; Kirilina Alla, Neizvestny Kirov, St. Petersburg / Moscow, Neva / Olma-Press, 2001, pp. 244-248. During the interrogation, Nikolayev denied he had associates.

152 For more detail see Kirilina Alla, Neizvestny Kirov, pp. 304-356.

153 See Reabilitatsiya: Kak eto bylo, Dokumenty, Vol. II, Moscow, MFD, 2003, p. 545; also O. Khlevniuk, Chozjajin, p. 233. The decree stated: Investigation of terrorist offenses should take no longer than 10 days; notification should be delivered to defendants 24 hours before the start of the trial; the hearing is to be held in the absence of 
was meant to function as a tool for eliminating internal party opposition, and with Stalin's intervention, the investigation radically changed course. No effort was made to obtain any real evidence of guilt. The focus was placed on coming up with a list of names of those who might have been designated 'conspirators. ${ }^{154}$ The trial took place on December 29, 1934 and took approximately 15 hours. Fourteen defendants, including Nikolayev, were condemned to death, and the ruling was carried out forthwith.

Zinoviev and Kamenev were also taken into custody during the investigation and brought to Leningrad. There, they were charged with 'moral and political responsibility' for the assassination. Along with Zinoviev, who was placed behind bars for ten years, and Kamenev, who was to serve five, nineteen other persons were sent to prison. The NKVD resolution resulted in seventy-seven former leading party functionaries being sentenced to internment in a 'concentration camp' or exiled to remote regions of the USSR. ${ }^{155}$ In subsequent trials, seventeen more people were condemned to death, seventy-six sentenced to prison, thirty to exile, and 988 to party punishment. Up to 11,000 members of the pre-revolution upper class were punished administratively. ${ }^{156}$

The main goal of these rulings was, however, not chiefly to punish the culprits, but rather to create a basis for mass terror to be carried out against members of the post-revolution political and social elite of the USSR. In general, rulings were handed down by a kangaroo court. State and party bodies, including VTsIK, the government, the Plenum of the Central Committee of VKS/b and even the Politburo were excluded from taking part in the decisions. The Politburo frequently approved the rulings only after the fact, by memorandum, or without a quorum

representatives of the procedural parties, i.e., of prosecutors and defence lawyers, judicial review is not allowed and death sentences shall be executed immediately after their publication. The act is dated 1.12.1934, the day the murder and was approved by the politburo and the presidium of VCIK SSSR only 3.12. It was abolished in 1956.

154 See Reabilitatsiya: Kak eto bylo, Vol. II, p. 547: "File material and review materials show that only Nikolayev's charges were justified...”.

155 Reabilitatsiya: Kak eto bylo, Vol. II, p. 551 Shvernik commission found out that "Zinoviev's Moscow counterrevolutionary centre did not exist. No person condemned in this matter had any relationship to the murder of Kirov...".

156 Reabilitatsija: Kak eto bylo, Vol. II, p. 553; also Khlevniuk O., Chozjajin, 237; Chaustov V./.Samuelson L, Stalin, NKVD i repressii, 64; According to later data that includes the purge in Leningrad of former members of the upper class and the purge of the border regions, up to 10,399 families were affected over the four months following December 1934 , ia total of 34,700 people, $70 \%$ of whom had formerly been members of the upper class. 
present. There are no doubts that Stalin intended to create a means to punish former members of the party opposition to an unlimited extent, and the initial targets were gradually broadened to taken the punishment of persons Stalin or other bodies decided were disloyal or hostile elements.

As we have already noted, Stalin had probably begun to set the stage for these steps starting in 1932. The famine was only separated from Kirov's death by the space of a year-and-a-half, and in 1932 Stalin began to try to establish capital punishment for party members, but the meaning and impact of Stalin's moves was not immediately transparent to his contemporaries. As part of his policy of moderation, he made a number of conciliatory gestures towards the party that may have disoriented his contemporaries. Even Stalin himself potentially may not have initially been clear about how far he wish to go along this path, but he was certainly clear that neither the public nor the party's upper tier were ready for terror to be turned on the party itself.

The attitudes of the NKVD leaders probably also constituted an especial stumbling block for Stalin. They are frequently trivialized in the literature. In May 1934, Vyacheslav R. Menzhinsky died. After Felix E. Dzerzhinsky, Vyacheslav R. Menzhinsky had become leader of OGPU. The administration of NKVD was taken over by Genrih G. Jagoda. This was clearly a move made under duress: the NKVD leadership was part of the top strata of the USSR, and it was far from clear what its behaviour would be in a situation in which sanctions on former and current party officials and a wider segment of the Soviet elite were at stake. Nikolai I. Yezhov appeared on the horizon of Soviet politics. Stalin entrusted him with the role of party supervisor of security bodies. Yezhov possessed neither education nor culture, and Stalin took advantage of his lack of independence and complete reliance upon Stalin.

\section{Changes in the International Situation and Soviet Politics}

The changes that we have been speaking about that were taking place within the internal political situation in the Soviet Union took place at a time when international relations were undergoing a significant shift. The turning point occurred with the rise of the Nazis to power in Germany in January 1933. This twist of events was a serious loss for Soviet foreign policy, because Soviet-German agreements had provided assurance for the USSR against any potential attack from the West. But under Hitler, Germany became the USSR's key military threat.

Originally, both Europe and the USSR grossly underestimated the impact of this turn of events in Germany. As early as October 1933, Germany exited the International Disarmament Conference, announcing immediately afterwards 
that it was also leaving the League of Nations. Demands for an increase in the number of Reichswehr troops and to place the Saarland under German control soon appeared on the negotiation table. In March 1935, Nazi Germany renewed universal conscription and made a significant effort to break the restrictions on building the air force and navy. Concerns about Germany had already appeared by the late 1920s, when France and the United States offered to conclude the so-called Kellogg-Briand Pact that bound signatories to resolve conflicts peacefully. ${ }^{157}$ The Soviet Union took advantage of the offer to conclude nonaggression agreements with Estonia, Finland, Latvia, Poland, and later even France, and its position improved further when Franklin Roosevelt decided to recognize the USSR de jure. The USA played an important role at the time in delivering machinery and equipment to the USSR, where several thousand American experts were at work installing these facilities.

In 1934, another turning point came for Soviet-European politics. The USSR joined the League of Nations and was seated on its council. This happened in spite of the negative connotation 'Agreement', 'Versailles', and 'League of Nations' had for the Soviets. But with these developments, the Soviets supported a plan to create an Eastern regional pact intended to protect the eastern portion of Central Europe against Nazi expansionism. These acts and attitudes, however, were thwarted by German diplomatic activities, under which a separate GermanPolish pact was set up in January 1934. This unfavourable development was reinforced by the assassination of King Alexander of Yugoslavia in the autumn of 1934. Jean Barthou, the French Minister of Foreign Affairs and one of the pact's promoters, was also a victim of the assassination.

But the problem did not lie exclusively in the German-Polish pact. The attitude of the English conservatives in power, who preferred a policy of reconciliation with Germany, was a serious obstacle to shackling Nazi aggression. As a result, the eastern regional pact lost a substantial part of its original meaning for the USSR. In 1935, the country concluded alliance agreements with France and the Czechoslovak Republic, but these agreements in no way replaced the originally planned eastern pact. France's ties to England words priority, and England, for its part, continued to avoid any conflict with Germany until the spring of 1939.

The alliance with France, though, did not enjoy Stalin's full support either. He likely believed that Nazi politicians did not seek war against the USSR as

157 Ort, Alexandr: Evropa 20. století. Prague: Arista, 2000, pp. 59-61, 69, 72-73. Aristid Briand was the Minister of Foreign Affairs; Frank J. Kellog was the US Secretary of State. The Pact was signed by six superpowers including Germany and a total of 57 countries cosigned. 
a priority, but rather wished to weaken France and Belgium, thereby opening room for Germany in Western Europe. ${ }^{158}$ Stalin was still cognizant of the experience of World War I, believed in the potential dominance of the Western countries, and did not wish to repeat Russia's experience from the war, which bled the country to death. All this likely impacted Stalin's attitude to potential collaboration between the Communists and the Social Democrats in Germany and other countries.

Stalin's attitude on these issues was nevertheless subjected to severe trials. The danger of a turn to the right soon also became acute in Austria, Spain, and France, where it caused the mobilization of left-wing forces that in 1936 brought victory to the government of the 'People's Front', headed by Leon Blum. The rise of this government was the result of a sharp turn by the French electorate in the communist direction. Stalin recommended French Communists not to participate in Blum's government but to support it 'from the outside', something which naturally brought no benefit to either the left-wing nature of the government or the People's Front.

The devastating consequences of Stalin's attitude were soon reflected in neighbouring Spain. There, the reinforced left-wing, together with its citizen supporters, created a government whose conflict with the right wing resulted in civil war. The French 'People's Front' government decided not to aid the Spanish Republicans, fearing an isolated conflict with Fascist Italy and Nazi Germany, which intervened in Spain. The British government, for its part, insisted on 'non-intervention', and exerted strong pressure upon Paris to comply, which it did. ${ }^{159}$ The Spanish generals who attacked the Republican government took this as a go-ahead. In autumn of 1936, Germany and Italy recognized the generals' government and continued to intervene.

We will not go into further detail about the events that unfolded in Spain. For our purposes, it is enough to note that Soviet policy did nothing to help protect the Spanish Republic from interventions, nor did it work toward making the USSR and its future allies opposed to Hitler draw closer. The Spanish civil war was primarily a gain for Stalin because it shifted the epicentre of international conflict away from Soviet borders, and particularly because it provided him with

158 Reference is made to Stalin's editing of Tuchachevsky's article entitled "Military Plans of Current Germany" and Tuchachevsky's "probing” in Paris and Berlin in January 1936. See Minakov S. T.: Voyennaya elita 20-30 godov XX. veka, Moscow, Russkoje slovo, 2004; pp. 421-422 and 424-426.

159 Cf. Furét F., Das Ende der Illusionen: Kommunismus im 20. Jahrhundert. MünchenZürich, Piper, 1998. pp. 316-319. 
the time he needed for his internal political purge. But Stalin could not remain on the sidelines of what was happening in Spain, even if he did not risk taking a direct part in the war. He sent no military units to Spain, but he did send 'specialists', military commanders and political commissioners who were charged with helping build Spanish security forces, and who intervened into the composition of Spanish government institutions and the general staff. ${ }^{160}$ International brigades made up of volunteers from various countries, particularly communists, fought on the side of the Republicans. Approximately 35,000 in number, they accounted for six of the 137 brigades operating within Republican Spain, and they fought bravely.

Midway through the purges unfolding in the USSR, Stalin could hardly have wished for serious international complications, but he was likely still basing his actions on the presumption that Hitler was primarily targeting the West. ${ }^{161}$ He therefore had no reason not to be happy that Germany and Italy had their hands busy in remote Spain. But he probably underestimated the significance of France's deepening dependency on Britain. The awakening came in September 1938 in Munich, when England and France sat down to the negotiation table with Hitler and Mussolini. The Spanish intermezzo had allowed Stalin time to murder his own countrymen and the social elites, including his army leadership, but it did not protect the USSR from Nazi expansionism, and it weakened the European left-wing and civic democratic parties as potential allies in the war against Hitler.

\section{Stalin's Constitution}

Stalin's foreign policy, particularly his policy on France and Spain must be noted. One glance will make apparent labyrinthine character and will reveal that Stalin's withdrawal from the policy of non-intervention in Spain was not a simple act of solidarity. It was tied to the webwork of his policy as a whole. The heightening of internal political repression and the manner in which it belied the promises of the new 'democratic' Soviet constitution was no accident. Stalin's trials were not targeted against 'perverts' or 'dissidents', but rather against 'terrorists' and

160 Erickson J., The Soviet High Command, pp. 429-432. The Soviet government continually denied the presence of Soviet soldiers and "volunteers" in Spain.

161 Ibid, 428-429; Politbyuro CK RKP/b-VKP/B: Resheniya 'osoboi papki' (treatise by M. M. Narinsky), pp. 300-302. 
'agents of foreign superpowers.' ${ }^{162}$ In choosing these labels, Stalin suggested he did not consider Nazi Germany or Imperial Japan his allies, and to the public he suggested that he was not trying to suppress democracy but to expand it. The proposed new constitution was to serve as testimony to this.

Stalin's internal policies were not aimed only at liquidating the opposition. An important goal was to reconstruct the mass of ties the regime had inherited from the 1920s. These represented an obstacle to Stalin's plans for centralization and were also a frequent basis for differences of opinion. This was also true for transferring the competencies of individual republics to nationwide institutions in Moscow.

Here we should take notice of voting reform. The literature has frequently interpreted this reform as a democratizing element of Stalin's constitution. Multistage elections were abolished, peasants and workers gained equal rights, and members of the upper stratum in pre-revolutionary Russia gained suffrage, but the reform did not touch the party power monopoly. 'The new draft constitution...maintains the working class dictatorship, just as it leaves the Communist Party unchanged in the leading position,' Moscow Pravda commented. ${ }^{163}$ With the abolition of multistage elections, the competencies of elected representative bodies were radically reduced, limiting their ability to influence the composition and policies of higher bodies.

For Stalin, the true achievement lay in the relationship between the party and the government, now anchored in the constitution. Earlier, the Politburo and the Central Committee of the governing party had possessed the power to discuss important issues related to government actions, but the party apparatus had no position of authority over leading representatives. The Prime Minister's position was firm, something which was particularly revealed when economic and social issues were resolved. The government and its bodies, STO and VSNCh, influenced the control, planning, and coordination of activities of the extensive state economic complex. Disputes between government officials and party officials were usually factual in nature and the competencies of party representatives were generally political. But Stalin continued to exert control over the operations of ministries that possessed power potential, such as OGPU,

162 Hitler ordered German diplomats whose names were mentioned in connection with trials to explaination the incidents. Their claimed the charges had no material basis. Moscow dismissed Germany's subsequent diplomatic intervention by saying the explanations had been offered by enemies of the country. (Politisches Archiv Auswärtiges Amtes, Botschaft Moskau A2l).

163 Pravda, 26.11.1936. 
the Ministry of Foreign Affairs, and the army. Originally, these were under the control of the head of government, who cemented his influence by promoting his own people to work in these ministries: Kliment Ye. Voroshilov, Anastas I. Mikoyan, Maxim M. Litvinov V.R. Menzhinsky and later N. I. Yezhov. Many times he removed people, who were capable and independent from these institutions, which was one of the conflicts he had with the Prime Minister and significant members of the government. Originally, there were system obstacles in place against the interference of the "party" in the government. On many occasions, he removed capable, independent people from these institutions, a source of conflict with the Prime Minister and with leading members of the government. Originally, the system had safeguards built in to keep the party from tampering with the government's areas of competency. Its role, and that of the Prime Minister, derived from the original notion that they should play a key role in the power structure. But Stalin viewed the role played by the government (SNK), the Soviet Bureau, and the Council of Labour and Defence (STO) with undisguised hatred. 'Our top Soviet political elite,' he said, 'is suffering a terminal disease. The STO has turned from a working, fighting body into an empty parliament. The SNK is paralyzed by Rykov's weak moves counter to party interests. The Deputy Committee has a tendency to behave like a team squared off against the Central Committee. It's clear this can't go on. ${ }^{164}$

But more than just these governmental bodies was involved. Other obstacles to Stalin included the VSNCh, People's Commissariat for Finance (Narkomfin) and the Military-Revolutionary Committee (VRS), which coordinated various aspects of the government's work. With the 'right-wing perverts' out of the way, Stalin began to carry out structural changes in the government. By appointing Molotov to the post of Prime Minister, the state became subject to party supervision. Stalin's policy moves were aimed at changing the government's role within the power structure and abolishing bodies that coordinated its operation from within. ${ }^{165}$ The constitution was democratic on paper only, since the democratization process was focused on electing bodies who were anyway losing their role as independent decision-makers.

164 Pis'ma I. V. Stalina V.M. Molotovu, p. 217 - Letter from Stalin to Molotov dated 13.9.1930.

165 Resolution of the Seventeenth Congress of VKS/B "Partiynoye i sovyetskoye stroitestvo”, in: KPSS v rezolyutsyakh i resheniyakh, Vol. II, pp. 765-771. 


\section{Stalin's “St. Bartholomew’s Day”}

The important thing about the 'constitutional' was that, as they were being prepared, Stalin was also beginning to carry out his acts of repression on a gradual basis. In the beginning, Stalin likely anticipated significant resistance, but he managed to prevent this in the end. In January 1935 in an atmosphere saturated with the murder of Kirov and the trials that followed and affected so many former leading party officials, a remarkable investigation got underway in the Kremlin. Its target was the source of rumours of a 'counterrevolutionary' nature, and the investigation centred on the 'terrorist intentions' of a 'conspiracy'. In the end, 112 people were taken into custody. Investigators stated there were three terrorist groups in the Kremlin and proposed penalties for 109 people. ${ }^{166}$

There is much speculation about the meaning of the investigation. Aside from changes to the protection of the Kremlin, its tangible result was the removal of Avel S. Enukidze, Secretary of the VCIK Presidium, who also oversaw the federal legislation. The party leadership reproached him for lacking a personnel party and criticized his lifestyle, with the result that he was transferred to the Transcaucasia, where he fell victim to Stalin's repression. ${ }^{167}$ The leaders of the VCIK were replaced and legislation was now subject to the party, i.e., to Stalin, V.M. Molotov, L. M. Kaganovich, K.Voroshilov and A. A. Zhdanov. ${ }^{168}$

We have already spoken of Stalin's effort to break through the walls of the 'fortress' to present the party as a leading power with true national scope. To this point, a clear nationalistic element was in evidence in Stalin's politics. His 'patriotism' was undoubtedly also a reaction to developments in Germany-he offered his experience from the mobilization. ${ }^{169} \mathrm{He}$ perceived foreign countries as permanent external threats and used the term 'patriotism' with exceeding care, preferring to speak instead of 'Soviet patriotism', thereby emphasizing that Russian patriotism within a multinational USSR could easily become an explosive issue. He was suspicious of people from nations whose statehood, religion and

166 See Lubyanka: Stalin i VCK-GPU-OGPU-NKVD, janvar'1922-dekabr'1936, eds. Chaustov V.N. et al.., Moscow, MFD, 2003. pp. 658-660 and 663-669.

167 Pravda, 8.6.1935; also Reabilitatsiya: Kak eto bylo, Vol. II, pp. 339-341 and 554.

168 Zhukov Yu., Inoy Stalin, p. 54, in detail O. Khlevniuk, Politbyuro: Mechanizmy politicheskoy vlasti, pp. 62-69.

169 This is testified to by contents of Soviet press. See Pravda, 9.6.1934 (Za rodinu!), 7.8.1934 (U rabochikh yest' rodina) and 19.3.1935 (Sovietsky patriotizm). 
culture originated outside Soviet borders, and this gave rise to a space within which to differentiate between 'Soviet' versus 'Russian' patriotism. ${ }^{170}$ Reinforcement came from the teaching of history ${ }^{171}$, whose resurrection had generated a flurry of patriotic themes in history, fiction, and the media. Its importance, however, should not be overestimated. Although Stalin's regime wished for a kind of national legitimacy, it continued to call upon October 1917 as its key source. This relationship to the country's past was tied to 'Marxist-Leninist' postulates that had been verified by the party. ${ }^{172}$ Stalin's political orientation was therefore not determined by patriotism so much as an effort to eliminate demonstrations of opposition of any kind, including nationalist thinking.

Here we come full circle back to the murder of the post-revolution Soviet elites. The purpose of this slaughter was not to promote Russian patriotism, but to eliminate any possibility of resistance to Stalin's regime, to get rid of the people and structures that embodied it. One can hardly assess Stalin's motives without a thorough analysis available of his thinking, and of the political and overall culture. As goes the brutality of his methods, Stalin was no exception for the twentieth century. He differed from other twentieth century dictators by reason of two things. The first was that starting in 1935, he brought terrorism to his own party, and the second, that he justified it by Marxist principles. Marxism was considered a universal theory of emancipation, even though it had acquired content and a number of features specific to Russia that made it extremist, used also against the Soviet post-revolution elite. ${ }^{173}$

Stalin's turn toward terror originally arose because of the shock and insecurity the regime experience during the 1932 famine, caused, as it was, by mistakes the regime made in setting out the first five-year plan. The impact was probably enhanced by the fact that Stalin had promoted his plans in the face of strong resistance from both the right and left wings of the party opposition. That he worried

170 This was characterised by Stalin's rejection of an essay written by Friedrich Engels entitled "The Foreign Policy of Russian Tzarism" (1934) which included harsh criticism of the foreign policy practised by the Czar's government. Cf. Vdovin A. I. / Zorin V. Ju. / Nikonov A. V., Russkiy narod v natsionalnoy politike, XX vek. Moscow, Russkiy mir, 1998, pp. 133-135.

171 See Istoriyu - v shkolu: sozdaniye pervych sovietskikh uchebnikov. (Eds. Kudrjashov S.) Vestnik archiva Prezidenta Rossiyskoy federatsii, Moscow 2008, pp. 121-124, cf. Barsenkov/Vdovin, Istorija Rossii, p. 242.

172 A substantial portion of this history consisted of "party history".

173 In this respect, as already noted by Trotsky, it possesses similarities to the French Thermidor. 
about the results of this resistance is apparent from his allegiance to a 'moderate course' on social change, as we have discussed.

At the time, Stalin probably lacked enough support from the top leadership to immediately shift in the direction of repression, particularly inside the party. ${ }^{174}$ Such a shift could not be made as a one-off, rapid move but only following the arrests and trials 'justified' by Kirov's murder. Stalin continued to apply pressure in this direction. Once the first trials were over, Stalin sent a letter to party organizations on behalf of the Central Committee of the VKS/b, and without consent of the Politburo. Its title was self-explanatory: 'On the Terrorist Actions Taken by Trotsky and Zinoviev's Counterrevolutionary Block'. He claimed this 'block' had been formed in late 1932, not only from Zinoviev's supporters, but also from Trotsky's. Their alleged goal was to assassinate leading officials, in particular Stalin, and these allegations clearly embodied Stalin's key objective, which was to put an end to organized opposition once and for all. ${ }^{175}$ Already by $1935,16,000$ people had been apprehended on 'terrorism' charges, punishable by death. Arrests were made frequently, with no material basis, and paranoia reigned both within the party and within security agencies.

Large-scale trials against the opposition were also implemented only after some time. Only in March 1936 did G.Yagoda inform Stalin that instructions for terrorist actions in the USSR had allegedly been issued by Trotsky and brought to the country by 'Gestapo agents'. He proposed imprisoning the Trotskyites for three to five years in remote camps, and executing those convicted by the Military Collegium of the Supreme Court of terrorism. Stalin had the proposition approved by the Politburo by memorandum. Yagoda had recommended bringing Zinoviev and Kamenev before the court once again, but he did not mention the 'Trotsky-Zinoviev core' at all. It was Stalin who insisted that they be 'exposed'. Yagoda's choice was likely no accident, and it was his and the NKVD leadership's fatal mistake. Its members were removed from their positions, then arrested. Yagoda's position was taken over by Yezhov, who brought in his own team, consisting primarily of members of NKVD regional branches who, having no supporters upon whom they could rely in Moscow, were easier manipulated than their predecessors had been.

174 See Stalin, Zhdanov - to Kaganovich, Molotov, 25.9.1936 g., in: Stalin i Kaganovich: Perepiska. 1931-1936 gg., pp. 682-683; on 1932 as a milestone see also Materialy fevral'sko-martovskogo plenuma CK VKP/b 1937 goda, in: Voprosy istorii No 10/94, pp. 13-27; No 11-12/94, pp. 3-29; No. 2/95, pp. 3-26.

175 Chaustov-Samuelson, Stalin, NKVD I repressii 1936-1938, pp. 58-59. 
The investigation into the 'Trotsky-Zinoviev core' took place relatively quickly, from 23 July until the mid-August $1936 .{ }^{176}$ The key defendants were Zinoviev and Kamenev, along with Ivan N. Smirnov, the former leader of the Siberian Bolsheviks. Beating, torture, and penalizing families were all used during the investigation, and Stalin personally interfered with both the indictments and the list of those accused, who included five members of the German Communist Party, still in the USSR after 1933 for understandable reasons. The trial itself took place in Moscow during the period from 19 to 24 August 1936, and all defendants were sentenced to death, with the sentences carried out straightaway.

This trial is notable not only because it was a bloodstained farce. Its reception told Stalin that both the party and the public were disoriented, surprised by the boldness of the accusations, to the extent that no protest would be mounted against the executions of former leading personalities, and this allowed him to launch a two-and-a-half year campaign of murder against the Soviet political and cultural elite. ${ }^{177}$ Soviet criminal law was expanded to include extrajudicial judgments and the murder of party members and functionaries, creating an atmosphere of deeprooted fear in the country in which the public and party remained mute about the endless string of arrests and murders. ${ }^{178}$ Calling these trials against former Bolshevik party and government officials 'Trotskyite Trials', as was done at the time, was as deceitful as were the trials themselves. A great majority of the accused had no relationship to Trotskyism in that era, and they presented no opposition, let alone engaged in terrorist acts. The January 1937 trial clearly targeted the leadership of the People's Commissariat of Heavy Industry, run by G.Ordzhonikidze, who committed suicide immediately after the trial. He had been considered a member of Stalin's circle of friends, and the public learned of his conflict with Stalin only decades after his death. ${ }^{179} \mathrm{~A}$ number of other former opposition members-Georgi L.

176 Many historians originally thought that resistance by the accused prolonged the 'investigation' for many weeks.

177 Chaustov V./ Samuelson L., in Stalin, NKVD i repressii (p. 93) indicate the following numbers of arrests of opposition members (supporters of Zinoviev and Trotsky): $1934-631,1935-3447$ and $1936-23,279$ persons.

178 In addition to the trial focused on the "Trotsky-Zinoviev Centre" in July-August 1936, there were trials against the so-called "Parallel Anti-Soviet Trotskyite Centre" (23-30 January 1937), “Anti-Soviet Military-Fascist Organization” (11 June 1937) and "Anti-Soviet Right-Wing Trotskyite Bloc" (2-13 March 1938).

179 O. Khlevniuk, Chozjajin: Stalin i utverzheniye stalinskoy diktatury, pp. 269-285; ibid, Stalin i Ordzhonikidze: Konflikty v Politbyuro v 30-e gody, Moscow. Rossiya molodaya, 1993, pp. 29-139. 
Pyatakov, Leonid P. Serebryakov, Karl Radek and Grigori Ya. Sokolnikov—were also brought for judgment at the same trial. But when they were arrested, they were loyal high officials of the regime. ${ }^{180}$ And the subsequent trial against the leadership of the Red Army had no relation to organized political opposition. ${ }^{181}$ The accused were instead members of the top leadership of the Soviet armed forces who were in favour of modernization, and who doubted the capabilities of Kliment Ye. Voroshilov, the People's Commissar for the Military.

The final 'Trotskyite Trial' targeted the 'block of Trotskyites and the right wing'. Key defendants were Rykov and Bukharin who, since 1936, had stood against Trotskyism. In fact the only thing the trial and Trotskyism had in common came with the artificial inclusion of the Trotskyites Ch. Rakovsky and Nikolay N. Krestinsky. Before his arrest, the latter had been First Deputy of the People's Commissar for Foreign Affairs and, briefly, held the identical position for the Commissar of Justice. Many of the accused had occupied ministerial posts as People's Commissars or served as their deputies, such as Alexei I. Rykov, Vladimir I. Ivanov, Mikhail A. Chernov, Nikolay N. Krestinsky, Genrikh G. Yagoda and Arkady P. Rosengolts, or were high-level representatives of republics such as Uzbekistan and Belarus. Defendants also included physicians accused of killing prominent patients, such as Maxim Gorky and Valerian V. Kuybyshev. Most of the people judged thus had no real part in the anti-Stalin opposition; most had recently served as high-level functionaries. In this, the trial was laid bare the real purpose of Stalin's trials: to justify the massacre of the post-revolution Soviet elite.

But this was not the only goal of Stalin's policy of repression. Again in June 1937, the purge of 'class-hostile and kulak elements' was renewed. Initiated with a Politburo resolution on 2 July 1937, it ordered local, regional, and republiclevel bodies to keep tabs on the suspect group. This resolution was followed by another, Yezhov's Order 00447, impacting 267,000 people, 76,000 of whom were executed. ${ }^{182}$ Quotas were drawn up for individual regions, areas, and republics

180 G. Ya. Sokolnikov, G.L. Pyatakov and L.P. Serebryakov were Deputies in various People's Commissariats. Pyatakov was the Deputy of Ordzhonikidze and member of the Central Committee. K. Radek also had a high position at the Central Committee of the $\mathrm{VKS} / \mathrm{b}$.

181 Originally, V.M. Primakov and V.K. Putna were also arrested. Putna worked as a military attaché in Britain. Primakov was a military attaché in Japan and later a Deputy to the Chief of Leningrad Army District.

182 Lubyanka: Stalin i Glavnoye upravleniye gosbezopasnosti NKVD 1937-1938, Eds. Chaustov V. N. et al. Moscow, MFD, 2004, pp. 234-235, 273-282, 467-468; Reabilitatsiya: Kak eto bylo, Vol. II, p. 609. 
stating how many were to be imprisoned or executed. Yezhov cared nothing for the life stories or actual culpability of these individuals. The measure was preventive. Such zeal in carrying out the campaign was shown by NKVD administrators that the quotas were rapidly met; new quotas were requested. Data from 1 November 1938 showed 770,000 people had been rounded up, 390,000 of whom were executed. And current calculations show that even these figures were probably eight and a half percent lower than the real number. ${ }^{183}$

A fascinating if horrible twist ${ }^{184}$ : in 1934, the civil rights of the displaced kulaks had been partially reinstated, along with the right to vote in $1935 .{ }^{185}$ The 2 July resolution and Order 00447 came out of the June Plenum of the Central Committee of VKS/b, held to discuss election preparations for the Supreme Soviet. The 'Kulak Action' was to end in late November of that year, with the elections following on 12 December. This means it is likely that the action was intended to set the limits of the equal rights possessed by the kulaks and prevent them from returning to their original homes. In any event, it offers proof in itself of the actual nature of the equal rights held by citizens of the USSR.

Repugnant as it was, the Kulak Action had nowhere near the impact on the villages as had forced collectivization and the expropriation of the kulaks. The focus should thus be shifted to acts undertaken against foreigners (inonatsionalnosti). ${ }^{186}$ First, they impacted nationals who had been part of the Russian Empire prior to 1917, but remained outside the borders of the USSR after the revolution. Second, they impacted those in nations that, after the disintegration of the Empire, had been cut in two by state borders. And finally, they impacted nationals whose countries had been outside the borders of the former Russian Empire. The Soviet leadership suspected these nations or national minorities might have been influenced by foreign intelligence services. For statutory nations like Ukraine, Belarus, Azerbaijan, or Armenia, the repression was usually justified by claiming a connection to foreign intelligence or to national or religious centres abroad. Important steps were directly under the control of Stalin and his immediate circle. $\mathrm{He}$

183 Khlevniuk O., Chozjajin: Stalin i utverzhdennie stalinskoy diktatury, p. 320; Stalinizm v sovetskoy provincii 1937-1938 gg.: Massovaya operatsiya na osnove prikaza No. 00447,. (Ed.) Junge M, Bonwetsch B., Moscow, ROSSPEN, 2009, (p. 15) indicates a total of 800,000, approximately half of whom were killed.

184 Lubyanka: Stalin i Glavnoye upravleniye gosbezopasnosti 1937-38, pp. 234-235.

185 Barsenkov/Vdovin, Istoriya Rossii, p. 231.

186 The term "inonatsionalnosti" is used by Chaustov V. / Samuelson L. in Stalin, NKVD i repressii, p. 286; another designation is used inthe 1963 committee report Reabilitatsiya: Kak eto bylo, Vol. II, p. 613. 
approved not only the scope of the repression, but also consented to the lists of people who would be affected. In this case, it was members of the Soviet establishment. They were Poles, Latvians, Lithuanians ${ }^{187}$; they were Comintern officials and former political émigrés. Their persecution was a political priority. Yezhov claimed 357,000 of them had been rounded up-today 328,000 seem closer to the mark - and 237,000 were executed. ${ }^{188}$

Stalin's personal antipathies were in clear evidence in the sanctions he placed on individual national groups. According to the Shvernik Commission, 147,500 Poles had been affected as of 1 July $1938 .{ }^{189}$ Only half as many sanctions-65,300-were visited on Germans who dwelt permanently in the Volga Basin, in Ukraine, the Baltics, who had a place to stay in Leningrad, or who, after 1933, fled the Nazis and came to join these people. ${ }^{190}$ Sanctions against people hailing from nations not officially members of the USSR began to attract attention from foreign embassies. ${ }^{191}$ There were fourteen such nationalities. The sanctions laid bare Stalin's real attitude to the national issue during the time socialism was being 'constructed'. For him, nations whose statehood was formed outside the USSR's borders were dangerous, and that included the Communists in their number. Most affected of the official members of the USSR were the Ukrainians, but the Islamic nations of the North Caucasus and the Transcaucasia were also targeted. For these countries, the Soviet secret service manufactured an allegiance to Turkey. Stalin clearly did not himself trust the results of his policy on the nations.

We have already noted that Stalin was substantially motivated to enact mass terror by his wish to bring under his control administrative, economic, and other state and political bodies that had previously maintained elements of independence. The January 1937 trial thus fell hard on the People's Commissariat for Heavy Industry. But more significant were the trial of the leadership of the Red Army and the action against the leaders of the NKVD. Stalin probably chose

187 Chaustov V./Samuelson L., Stalin, NKVD i repressii 288-292; Lubyanka: Stalin $i$ Glavnoje upravleniye gosbezopasnosti NKVD 1937-1938, pp. 301-322, 325-326, 351, 352-359, 366-373 etc.

188 Reabilitatsiya: Kak eto bylo, Vol. II, p. 617.

189 Victims from Katyn and Ostashkov and persons affected in territory annexed by the USSR in September 1939.

190 The penalizing of “imperial” Germans, i.e., citizens of Germany, see Vatlin A. Yu., Graf Friedrich Werner von der Schulenburg i epocha massovych repressij v SSSR, in: Voprosy istorii, 2/2012, pp. 32-54; also Barsenkov/Vdovin, p. 254.

191 See. Chaustov V/ Samuelson L., Stalin, NKVD i repressii pp. 307-308. 
this parallel strike against the leadership of the army and that of the NKVD not simply because they possessed traces of internal autonomy, but because they were armed units.

The autonomy of the army had already been a thorn in Stalin's side when Trotsky was the leader of the military forces. After his exit, the officer corps was thoroughly cleansed-K. Ye. Voroshilov stated up to 47,000 officers were 'dismissed' over a period of a few years. ${ }^{192}$ But the motivation was economic as well as political: the state didn't have the money to maintain the army. Only $26 \%$ of troops were full-time soldiers; the rest were in the so-called territorial divisions, where members served without being forced to leave their civil employment or their homes. ${ }^{193}$

The senseless massacre of the Red Army leadership took place on the eve of war, at a time when the USSR's international position was threatened by potential conflicts. Stalin's motive in carrying out the purge could therefore not have been to ensure the country's safety. It was about making internal political changes to secure his own control over the country. ${ }^{194}$ The massacre of the top brass was done blitzkrieg-style and, as is often forgotten in the literature, in parallel with the elimination of the NKVD leadership. ${ }^{195}$ Stalin and his circle likely feared the potential for solidarity between these uniformed centres of power.

We suffer no illusions as to the NKVD's willingness to moderate the terror against regime opponents. After all, its predecessor, OGPU, had been responsible for a number of show trials and groundless acts of repression. But one must not forget that during the years of Soviet power, NKVD's top leaders built ties with party and governmental leaders, and these influenced their personal and professional attitudes. We may also presume that members of the security forces were not spared by the 1932 famine and the outrage over Stalin's ruthless policies. Testimony to this lies in materials from the Plenum of the Central Committee of VKS/b from February and March 1937 focused on NKVD operations. One of the key accusations against the NKVD leadership was its lack of enthusiasm

192 Chaustov V./ Samuelson L., Stalin, NKVD i repressii (p. 106) indicate that the most extensive discharge of soldiers $(22,300)$ took place in 1933.

193 Pechenkin A. A., Voyennaya elita v 1935-1939 gg.: Repressiii i obnovlenie, Moscow 2003, pp. 14-15; service consisted of training exercises and camps.

194 See, Kantor Ju. Z., Zaklyataya druzhba: sekretnoye sotrudnichestvo SSSR i Germanii v 1920-1930-ye gody. SPb, Piter, 2009.

195 See Naumov L., Stalin i NKVD, pp. 198-213. 
about particular acts of repression, something which was labelled a 'betrayal' and penalized as such. ${ }^{196}$.

The cause behind the massacre of the Soviet post-revolution elite may be seen as lying in the spontaneous dynamics that arose from the paranoia ignited by Stalin's search for enemies. The waves of repression may thus have markedly exceeded what their organizers had intended. Added to this was the factor of surprise. Very little time elapsed between the arrest of Yagoda's NKVD leadership, the army brass, and the onset of repression against the Soviet elite. Only two weeks after the execution of the army commanders, on the 23-29 June 1937 the Plenum of the Central Committee of VKS/b took place to discuss election preparations and agriculture. But in listening to Yezhov's report on the NKVD investigation, Central Committee members found themselves confronted with a mandate to eliminate thirty-six of their own for 'loss of confidence' or 'betrayal of the party'. This relieved the committee of almost one-third of its membership. ${ }^{197}$ The same session heard a proposal to create an extrajudicial troika for Western Siberia, authorized to serve as a quorum to issue death sentences. It set a precedent. Soon, these troikas became tools of mass terror throughout the USSR. In 1937-38, they handed down the majority of the more than 700,000 death sentences. ${ }^{198}$

The scope of loss among the political and social elites in the USSR during these years defies comprehension. A huge number of the leading officials of the party and of the government, of unions and autonomous republics, interest and social organizations, the diplomatic corps, the security services, Comintern-all were executed or sentenced to long stretches behind bars on the basis of lists drawn up by the NKVD for Stalin. Also impacted were scientists and artists, particularly those whose work contradicted Stalin's ideology, or his politics, or

196 See Materialy fevralsko-martovskogo plenuma CK VKP/b 1937 goda, in: Voprosy istorii No 10/94, pp. 13-27; No 11-12/94, pp. 3-29; No 2/95, pp. 3-26. Naumov L., Stalin $i$ NKVD, 198, cites the former Chekist M. Shrejder: "Aside from sabotaging the heightened fight against paper Trotskyites, Old Chekists showed no enthusiasm in these matters"; Chaustov V. / Samuelson L. in Stalin, NKVD i repressii (p. 258) stated the number of the state security members dismissed between 1.10.1936 and 1.9.1938 was 9171 and those apprehended 2273 (296 - at the central administration, rest at regional offices).

197 Chaustov V. / Samuelson, L. Stalin, NKVD i repressii pp. 260-263; also Khlevniuk O., Chozjajin: Stalin i utverzhdenije stalinskoj diktatury, pp. 311-312.

198 Khlevniuk O., Chozjajin:Stalin i utverzhdeniye stalinskoy diktatury, p. 320. He refers to the fact that even here the actual figures were $8.5 \%$ higher than those indicated in official sources. 
his views on art. The new generation of social scientists was accordingly heavily impacted.

Between 27 February and 29 September 1938, Stalin received a total of 383 lists featuring the names of 44,161 people. Recommended punishments were attached. With these in hand, Stalin and his circle sentenced 38,627 people to death; 5430 to ten years' imprisonment; and 104 people to eight years in prison. Three additional such lists were found later, dating to the time when Yezhov was replaced by Lavrentiy P. Beria at the NKVD. The total number of people sentenced to death thus reached almost 40,000, and more were sentenced to long prison terms, as well. ${ }^{199}$ Among the executed were several members of the Politburo, many People's Commissars and their deputies, and 98 out of the 139 members of the Central Committee of the governing party. Of the 1,966 delegates to the Seventeenth Congress of the VKS/b in 1934, 1,108 were arrested. And the situation was similar in the Soviet 'Parliament', the VCIK: in 1937, 149 members were arrested without the Presidium having been informed. Added to all this was the torture, imprisonment, and execution of family members of these 'people's enemies.'200

But even these numbers fail utterly to capture the real depth of the loss suffered by those in the Soviet elite. Stalin and his circle were not the only ones culpable. There were also the troikas, as well as NKVD bodies and judicial colleges, responsible for thousands of people who were tortured to death or killed in camps with no judicial oversight. Evidence of the time or circumstances of their deaths is usually difficult to find. And to make matters worse, in autumn 1937, Stalin started trials at the regional level, with the same outcome as what had occurred before on the national level. ${ }^{201}$

Party members also suffered notable losses. The 1963 Shvernik Commission put the figures at 55,428 victims for 1937 and 61,457 victims four 1938, a total of almost 117,000 . But later sources raise that to more than 170,000 people. Around $40 \%, 46,000$ of the victims, were sentenced because their names appeared on the

199 Reabilitatsiya:Kak eto bylo, Vol. II, 592 and 646. Records from Beria’s period include a document dated 16.2.1939 consenting to the executions of 469 people, a document dated 8.4.1939 including 931 names, 198 of whom were to be sentenced to death, with 'at least 15 years' for the rest, and another document featuring 457 names, 346 of whom were to be sentenced to death and the rest to 'at least 15 years in prison'.

200 Reabilitaitsiya: Kak eto bylo, Vol. II, pp. 621-623 and 576.

201 Vert Nikolay (Wert, Nicolas): Terror i besporyadok: Stalinizm kak sistema (La Térreur et le Déssarroir: Staline et son systeme, Paris, Perrin, 2007) Moscow, ROSSPEN, 2010, p. $267 / 288$. 
lists that had been signed by Stalin and his circle. ${ }^{202}$ But the actual figures are likely much higher. One-and-a-half to two million party members were ousted. When arrested, they were not registered as communists. And there were some in the postrevolution upper stratum in the USSR who, for various reasons, had remained without any party affiliation. They were also turned over to the executioner.

In speaking of the elimination of these post-revolution elites, we have primarily intended people who were formerly communists or who held significant positions in society and government. We have avoided terms such as 'nomenklatura' and 'partocracy' that have been used by some authors. The nomenklatura we have dealt with elsewhere: it ordinarily consists of the members of a party or a state bureaucracy. But in our case, its members hail from a social stratum consisting of people who, twenty years after the revolution, were distinguished by their qualifications, their professions, and their employment. In addition to the power bureaucracy, members of the nomenklatura were also highly qualified economic directors and experts, military commanders, officers in interest organizations, and people who were active in cultural, scientific, and educational pursuits. These people had gained extensive knowledge and experience since the revolution, and many significantly impacted the development of the sciences and the arts in the 1920s and 1930s. It is therefore wrong to assess their competency on the basis of party affiliation or level of education attained. After being purged, they were replaced by others brought up during the Stalin era, people who lacked experience in independent decision-making. The mass nature of the campaign, and the fact that the liquidation of post-revolution elites took place both within the centre and across the republics, regions, and among large enterprises, was intended to ensure the long-term stability and resilience of Stalin's regime.

202 Reabilitatsiya: Kak eto bylo, Vol. II, 592, pp. 646 and 668; recent data (Khlevniu; k O., Chozjajin, pp. 350 and 352) indicate 117,500 excluded members in 1937 and 57,000 in 1938 . We have not provided corrected figures, because we have no way to verify their credibility. 



\section{Consequences of Mass Massacre of the Soviet Elites}

\section{The Country after the Mass Massacre of Elites}

The consequences of the massacre are revealed most clearly using the army as an example. The army was a complex, autonomous unit of the state and social system, tested by the war with Hitler's Germany that broke out soon after the massacre took place. As has been noted, its development was curtailed in the 1920s, and this changed only in the early 1930s in response to the rise of Nazi Germany and Japan as threats in Europe and the Far East. Red Army units began to multiply rapidly, as did their weapon systems. Demands increased for more, better educated army officers, and commanders originally focused on the Reichswehr expanded their international contacts. ${ }^{203}$ Soviet army officers began to take part in negotiations with diplomats and soldiers from a number of countries on a more regular basis. They acquainted themselves with the latest warfare technology and modified their notions of war. This deepened the gap between these professional commanders and Voroshilov, the People's Commissar at the ministry, prompting Stalin to reinforce his control over the armed forces. The People's Commissariat for Military and Navy Issues was replaced by the People's Commissariat for Defence, and the Military Revolutionary Council, a political entity which had co-decision powers over army expansion and deployment, was disbanded.

But these changes did not extinguish the tension in the armed forces. Mikhail N. Tukhachevsky, who had assumed significant authority during the civil war, grew in influence. A former official of the Guards, he provoked baseless hopes among those abroad, who saw him as a representative of prerevolutionary officials hoping to overthrow the Soviet regime. This gave rise to many 'soldier conspiracy' theories. Nazi intelligence made use of them in the 1930s to try to compromise the leading actors responsible for the Soviet military. ${ }^{204}$

203 Pechenkin A. A., Voyennaya elita v 1935-1939 gg. p. 13. and Khlevniuk O., Chozjajin: Stalin i utverzhdeniye stalinskoy diktatury (p. 291) indicate that from 1935 until 1938 the army grew by a half a million and consisted of 1.5 million soldiers; the costs the army incurred over the same period of time increased from 2.3 billion to 4 billion in 1937 and 6.9 billion rubles in 1938.

204 Reabilitatsiya: Kak eto bylo, Vol. II, 741-748 and 748-760, more recently see Kantor Yu., Zaklyataya druzhba, pp. 133-199. 
Stalin and the party leadership did not always see eye-to-eye on defence issues. ${ }^{205}$ But the conflict personified by Mikhail N.Tukhachevsky and K. Ye. Voroshilov seems to have been important for the future. Voroshilov favoured commanders who had served during the civil war, and underestimated the importance of modernized armed forces. Stalin was far from neutral; Voroshilov was a member of his political circle, a guarantee to Stalin that the army would remain under his control. Stalin probably also feared that the army and the head of the NKVD would join forces. Yezhov's agents forced 'evidence' of a military conspiracy out of Yagoda's NKVD members ${ }^{206}$, resulting in the arrests after intense interrogations in May 1937 of M. N. Tukhachevsky, Iona E. Yakir, Ieronim P. Uborevich, Avgust I. Kork, Robert P. Eideman and Boris M. Feldman.

For the Soviet armed forces, the trials against the army leadership bore grave consequences. ${ }^{207}$ Between 1937 and 1938, from 35,000 to 36,500 officials, depending upon the data used, were removed from their positions. Their fate during the Stalinist purges has recently been the focus of work by Aleksandr A. Pechenkin $^{208}$, who says that from 1934-38, seven out of ten deputies to the People's Commissar for Defence were executed, and an eighth, Yan Gamarnik, shot himself. Three-quarters of department heads in the Commissariat were replaced in 1938-39. Of the thirteen heads of army units in the position in early 1937, twelve were executed. The same end awaited seven of their replacements. 100\% of the deputies and auxiliary chiefs of military districts were replaced, as were $100 \%$ of district military chiefs of staff. At the peak of the army purge, from March 1937 until March 1938, forty-four commanders at the district level were ejected from the army, along with ninety-five division commanders, sixty-nine headquarters division chiefs, and 295 commanders and regimental staff officers. ${ }^{209}$ The losses

205 S. Minakov, Voyennaya elita 20-30-ch rodov, pp. 429-437.

206 Reabilitatsiya: Kak eto bylo, Vol. II (pp. 673-674). Voyennyi soviet pri narodnom komissare oborony SSSR, 1.-4. iyunya 1937 g.: Dokumenty i materialy, Moscow, ROSSPEN, 2008, p. 130. NKVD officials who testified against soldiers included Georgy (Yegor) A. Prokofiev, Mark I. Gay and Zakhar II. Volovich. Yagoda refused to provide any testimony.

207 Most members of the army tribunal, including 2 marshals, were also later executed. For detailed information see Litera Bohuslav, Sovětská armáda a "Velký teror" 1937-1938, pp. 239-266.

208 Pechenkin A. A. Voennaya Elita SSSR v 1935-1939 gg. pp. 98-132. However data on political officials and arrests that took place after people were released from the army is missing.

209 Between 1937 and 1938, 78 people at the rank of "Comcor" or the corresponding were stripped of their positions, 58 of whom were arrested; 229 at the rank 
were extraordinary and the experience and knowledge sacrificed irreplaceable. Marshall Aleksandr M. Vasilevsky, Stalin's closest army collaborator, told the writer Konstantin Simonov, 'You say without the defeats of 1937 there would have been no defeats of 1941. I would go further. Without 1937, there would have been no war of 1941. A great part of Hitler's ... decision for war came from his assessment of the extent to which cadres had been massacred ... There were a number of divisions under the command of captains because all the higher ranks had been arrested, no exception.'210

We have detailed how a substantial part of Stalin's intent was to place large administrative units with lingering traces of independence under his control. Changes prepare the way for the adoption of the Stalin Constitution of 1936, concentrating power in the hands of a tight circle of people, Stalin's core in the Politburo. And the same applies to the rights of national units, whose competencies were cut to benefit the power centre, and to the internal structure of the government, where many bodies that allowed individual ministries to resolve mutual issues within the government were scrapped.

The work carried out by the people's commissariats also suffered heavily. We have already touched on the fate of the People's Commissariat for Heavy Industry (known until 1932, as VSNCh). Kaganovich, who took over another key commissariat, the Commissariat for Transportation, six months after Ordzhonikidze's death, undertook vigorous purge that 'reduced' its leading cadres. Afterwards, in January 1939, Stalin divided up the rest of the commissariat, placing it under several different ministries and thereby getting rid of what remained of those who had overseen industry in the USSR. ${ }^{211}$ Other ministries were similarly cleansed. The 'Trotskyite Trials' and the arrests that accompanied them rounded up people's commissars, their deputies, heads of economic units, and directors of large enterprises and construction projects. Stalin also tried to place individual economic sectors under the control of the party apparatus. Party bodies were thus granted broad rights to assign key positions within the ministries, as well

of "Comdiv" or corresponding, 125 of whom were arrested; 543 at the rank of "Combrig" or corresponding, 251 of whom were arrested; at the rank of colonel or corresponding, 1,871, of whom 832 were arrested; and over 35,000 people in ranks ranging from junior lieutenant to major stripped of their positions, 6341 of whom-17.8\%-were arrested.

210 Simonov K., Stalin i voyna, in: Simonov K., Izbrannoye, Yekaterinburg, U-Faktoriya, 2005, p. 619.

211 Reabilitatsiya: Kak eto bylo, Vol. II, pp. 580-585. Chaustov V./ Samuelson L., Stalin, NKVD i repressii, pp. 315-317 and 319. 
as to intervene in the work of individual ministries, enterprises, agricultural machine and tractor stations, and state and collective farms. The ongoing terror continued to impact the ability of these institutions and enterprises to behave rationally. Only in autumn 1938 did some relief come.

Data on the intensity of the terror at lower levels of the social hierarchy is also chillingly revealing. In 1937, 353,074 ordinary citizens were sentenced to death. In 1938 , it was 328,618 people. That means in 1937,970 people were executed each and every day, and in the following year 900 people per day. By comparison, in 1935 in 1936, there had been three to four executions per day, also, of course, not a negligible number. ${ }^{212}$

Some Russian historians positively evaluate the growth in industrial production and improved agricultural indicators during the final five-year plan before the war. They also highlight the success in manufacturing weapons systems and increasing the army's combat capabilities. Other authors are more reserved. ${ }^{213}$ When the negotiations which took place at the Eighteenth Conference of the $\mathrm{VKS} / \mathrm{b}$ in February 1941, the final such conference before the war, are taken into account, we must conclude that in actuality, production and administration in many areas of civic life were less than satisfactory. Descriptions of the pre-war economy and pre-war social life reveal that economic disproportion had deepened. They register rapid growth in the production of armaments and machinery, but point to inadequate performance in light industry, agriculture, and civil construction. The growth of heavy industry and the manufacture of armaments continued at the expense of the population's basic needs. Another source of suffering was that after the defeat of France and England in mid-1940, the USSR had re-established an eight-hour working day and a seven-day workweek. ${ }^{214}$ Harsh punishments were imposed for work absences or breaches of work discipline.

The positive aspects we have noted about the Soviet Union in the 1930s were in many respects still present on a surface level in Soviet life right up to the outbreak of war. But these phenomena were belied by the 1937-38 terror and its impact not only on the mood of the inhabitants, particularly city dwellers, but on the pace of progress itself. People pulled together in an outsize exertion of national strength, but its duration was short and, because of the mistakes Stalin had made in the first five-year plan, could not resolve the USSR's modernization problems. The country's transformation into a modern nation, one with developed industry

212 Barsenkov/Vdovin, Istoriya SSSR, p. 256.

213 Barsenkov/Vdovin, Istoriya SSSR, pp. 283-288; cf. Hildermeier M., Geschichte der Sowjetunion pp. 481-487 and 487-493.

214 Until that point, there had been a 7-hour workday and 6-day workweek in the USSR. 
and a developed society, was underway but far from complete. The USSR was not ready for a conflict the size of World War II. And the 1937-38 terror had weakened the country, hampered its ability to defend itself and brought staggering losses of territory, people, and material assets during the war's first two years in 1941 and 1942.

\section{USSR on the Brink of War}

The threat of war against the USSR hardly came as a bolt from the blue. The political situation had been rapidly deteriorating since 1937, and the potential for war was signalled by agreements between Germany, Italy, and Japan, the countries that formed the basis of the Berlin-Rome-Tokyo 'Axis.215 The chief threat was Nazi Germany, but these two superpowers had both been in the World War I Alliance; their current affiliation with Germany showed the changes which had taken place in the European and global balance of power. Nazi expansionism immediately took aim at Austria and the Czechoslovak Republic, but over the long term, Poland was also a focus, shifting the threat of conflict measurably closer to the borders of the USSR. Conflict in fact broke out between the USSR and Japan at the Manchurian, Korean, and Soviet border at a time when friction in Eastern Europe had also intensified. The Soviet commanders, weakened by the purges, lack confidence, but in the end the conflict did not balloon into a serious issue. A head-on collision occurred nevertheless between the Soviets and the Japanese army the very next year in Outer Mongolia. The USSR came out of this the winner, and this permitted a diplomatic settlement of the country's relationships with Japan. Japan focused on war in China and Asia, avoiding hostilities with the USSR in 1941. But even with this, the Soviet government was less than certain about Japan's attitude, fearing that it might have to fight a war on two fronts. ${ }^{216}$

But from the USSR's standpoint, the main issue was nevertheless not the Far East and Asia. Unfavourable developments in Europe had multiplied in intensity from 1937, when British government member and later Foreign Minister Edward F. Halifax indicated he understood Hitler's wish to control Austria, the Czechoslovak Republic and Gdansk. ${ }^{217}$ Stalin's army purges and those he carried out in the government and the party hardly inspired the trust of his potential

215 Nálevka V., Světová politika ve 20.století, pp. 132 and 143.

216 Barsenkov/Vdovin, Istoriya Rossii, pp. 276-277; cf., collection Chanchin-Gol, 39, eds. G. P. Solonicyn. Moscow, DOSAAF SSSR, 1989.

217 Nálevka V., Světová politika ve 20.století, p. 143. 
allies in the USSR's competence to succeed in a war against a strong enemy. ${ }^{218}$ In March 1938, Nazi Germany annexed Austria and it was clear that the Czechoslovak Republic would follow soon after. It seemed unlikely Britain and France would risk war with Germany to save the Czechoslovak Republic. The USSR was forced to rethink its attitude. The agreement between Great Britain, France, Italy, and Germany, made on 29 September 1938 in Munich, simplified Soviet decision-making by releasing it from contractual obligations that dated to 1935 that would have mandated it enter the war. But the Munich Agreement also convinced Stalin that the Western Allies wanted Hitler to focus on Eastern Europe $^{219}$, and he therefore saw a pressing need to consolidate the country's internal situation and mitigate the tense relationships with Nazi Germany.

Stalin and his circle nevertheless reacted slowly. For the first two thirds of 1938, there was no substantive change in the ongoing massacre of the elites, and the numbers of those executed hardly decreased from the 1937 figures. ${ }^{220}$ The camps and prisons were overflowing and repressive measures played havoc with production at individual facilities and throughout economic sectors. Acts against foreigners instigated diplomatic collisions with foreign states, and cases in which Soviet diplomats and security service agents stayed abroad were on the increase. 221

But the trial we have already detailed against the 'right-wing Trotskyite block' formed the turning point. It was not the final act in the series of executions and the repression carried out against individuals Stalin and his circle wished to kill, or whose freedom they wished to take away. Still waiting for prison sentences were members of the Central Committee and the Politburo of the VKS/b and candidates for those positions, including Stanislav V. Kosior, Vlas Ya. Chubar, Jānis Rudzutaks, Robert I. Eiche and many other high-level functionaries in the regime. But Stalin and those around him could not entirely ignore the warning signals coming from abroad. The USSR's isolation grew and the continuing repression made it impossible to consolidate political and economic conditions. Workers with experience continued to be replaced by those in the third or fourth ranks of the regime's bureaucracy, or by beginners who had no idea how to carry

218 Erickson J., The Soviet High Command, pp. 488-489.

219 Werth N.; Istoriya sovetskogo gosudarstva, pp. 287-288.

220 However, finally the last quarter of 1938 was impacted by the prepared mitigation of repressions which, on the other hand, increased the number of people sentenced to long-term imprisonment (15 to 25 years).

221 Declaration by Fyodor Raskolnikov, Alexander Barmin, Walter Krivitsky and others, generally see Chaustov V./ . Samuelson L, Stalin, NKVD i repressii, pp. 308-312. 
out their functions. Some time in mid-1938, this state of affairs forced the realization on Stalin and his circle that the mass repression must end and measures must be taken to stabilize the situation. About a month after the 'right-wing Trotskyite' trial, personnel changes changed the momentum. In the middle of August 1938 at a meeting of the top leadership of the VKS/b, the name of Lavrentiy P. Beria was proposed for Head Secretary of the NKVD, and he began work in Moscow in mid-September 1938, shortly thereafter assuming Yezhov's position as head of the commissariat. ${ }^{222}$

As Yezhov's deputy, Beria had already had a free hand to carry out radical changes. The organizational work for the VKS/b Central Committee was taken care of by Georgy M. Malenkov. The pair's immediate brief was to halt the machinery of mass terror and stabilize the situation in the country. ${ }^{223}$ The fundamental organizational and cadre measures taken required about three months of intensive work. Candidates for responsible positions were difficult to find-the terror and purges had involved not only the security and judicial apparatus, but those of the party and state, as well. Many of the involved had considerable influence and connections.

Resolutions adopted by the government and the VKS/b Central Committee dated 17 November and 1 December 1938 changed security and disciplinary practices. ${ }^{224}$ Mass actions by the NKVD were halted immediately, as were the arrest and displacement of ordinary citizens. In the future, arrests were to take place only on an individual basis, with consent from a prosecutor. If leading party functionaries were involved or leaders of state institutions, the appropriate People's Commissar or head of the central institution had to authorize the arrest, as well. For MPs in the parliament of the USSR or those of the union or autonomous republics, consent from the pertinent legislative bodies was required. A set legal procedure was reinstated and the extrajudicial bodies that had decided on punishment were scrapped. ${ }^{225}$

222 See Zhukov Yu. N., Tayny Kremlya, pp. 65-68; see also, Amy Knight, Beria:Stalin's First Lieutenant, Princeton Univ. Press, 1995; Beria was appointed to the NKVD via a politburo resolution dated 21.8.1938. See Lubyanka: Stalin i Glavnoye upravlenie gosbezopasnosti NKVD 1937-1938, p. 545.

223 See Lubyanka: Stalin i Glavnoye upravlenie gosbezopasnosti NKVD 1937-1938, pp. 550-552.

224 See Lubyanka: Stalin i Glavnoye upravlenie gosbezopasnosti NKVD 1937-1938, pp. 607-611 and 624-625.

225 This measure did not concern the politburo and Stalin and the ad hoc created bodies. 
These measures were, however, significantly restricted. The kangaroo court was still in place. Decisions on politically motivated punishments continued to be reserved to Stalin and his circle. For such cases, the criminal code, judicial procedure and the prosecutor's opinion did not apply. Mass purges were still carried out in agencies where the regime found the people employed impossible to tolerate. The gravest instance took place at the People's Commissariat of foreign affairs in the context of the ousting of Maxim Litvinov. ${ }^{226}$ Executions, as noted above, continued to be carried out for those on the lists approved by Stalin, and the same formula was used to decide on the executions of Polish officers in Katyn, Ostashkov, and elsewhere. In August 1940, Leon Trotsky was murdered in Mexico on Stalin's orders. But in spite of this, after the changes of late 1938, the steady stream of unjustified arrests and executions diminished substantially. The end of the Yezhov era came with expressions of the long suppressed resentment the public harboured over the unreasonable, unjustified acts of repression. Such a mood was also evident in the preparations for the Eighteenth Congress of the VKS/b in spring 1939. NKVD leaders panicked; they committed suicide in greater numbers. They did not feel responsible for their actions, because they had been instructed to carry them out by those above. There is no point in us pointing the finger of moral culpability at them-such attitudes were standard for the politics and ethics of Stalin and his circle. ${ }^{227}$

226 Litvinov was recognized as a supporter of the British and American orientation in foreign policy and was Jewish by origin which, from Stalin's point of view, prevented the USSR from meeting Nazi diplomats and leaders.

227 Khlevniuk O., Chozjajin: Stalin i utverzhdenie stalinskoy diktatury, pp. 353-359. 


\section{The USSR in the Second World War, 1941-1945}

\section{June 1941}

Regardless of their significance, the aim here is not to describe the twists and turns of Soviet development between 1938 and 1941. The USSR was still a country far from mastering the problems posed by its own economic and civilizational revolution, nor was it able to benefit from the economic and civilizational progress attained internationally. It remained an unreliable partner to England and France, which did not trust the country's intentions. On the eve of the new world war, the USSR was thus isolated, unprepared for the conflict with Nazi Germany.

With this in mind, there is no point in looking back to the Molotov-Ribbentrop Pact of August 1939 and subsequent agreements between the USSR and Nazi Germany. These profited from the mutual distrust between the USSR and Western states. But in our opinion, it was Great Britain's policy which went furthest in enabling Nazi Germany and its allies to act aggressively. Not only did Britain's policy aim at 'reconciling' with Germany. It also weakened the position of France in continental Europe and particularly in the east of Central Europe. The policy contributed to the restoration of Germany's military power, culminating in the September 1938 Munich Agreement, which saw the Czechoslovak Republic handed over to Hitler and Nazi Germany gazing eastward toward Poland, which inevitably became its first victim.

Nazi Germany's attack on the USSR came on the night of 21 June 1941, and it came as a surprise in spite of frequent warnings from the intelligence services and from some foreign politicians. The Soviet leadership was thus not caught off guard by a lack of information. It has been suggested that the attack would indeed come in May or June 1941, but Stalin's reaction was inadequate. It is likely Hitler's intentions were not yet clear enough to him. ${ }^{228}$ Hitler's failure to crush Britain in an era war might have led Stalin to believe that Germany's war might was lacking, and that Hitler would not be willing to face a war with two fronts.

228 Voyennaya razvedka informiruyet: Dokumenty Razvedupravlenya Krasnoy Armii. Janvar' 1939-1941. Ed. Gavrilov V., Moscow, MDF, 2008, pp. 622-714; also see Gorodetsky G., Rokovoi samoobman: Stalin i napadenie Germanii na Sovietsky soiuz, Moscow, ROSSPEN, 2008, pp. 333-339. 
Nor can it be forgotten that Stalin had hoped to postpone the Soviet German conflict until 1942 or 43; he was certainly aware that his country was not ready for war, and a later start could only improve the USSR's position.

We are not of the opinion that Hitler attacked to forestall a Soviet push against the German forces in Poland. ${ }^{229}$ It is therefore worth going into greater detail about the clues that indicate Stalin was considering entering the war at a later point in time. In 1940, Britain had been pushed off the map of continental Europe, and was hardly able to return by its own power. At that point, the United States of America was not yet taking a direct part in the European war. Before the fall of France in June 1940, Stalin had probably incorrectly sized up the course of the war. He believed that, in many ways, it would follow the same course as had World War I before it, and this is testified to by comments in Soviet periodicals of the time. Stalin must have remembered what happened in that war very well; England and France provided good reason for trepidation by the way they led what has become known as the 'Phony War' against Germany until spring 1940. The outcome of the agreement between France, the Czechoslovak Republic and the USSR was also fresh in memory, as were Soviet negotiations with diplomats and military delegations from Great Britain and France in 1939. It is thus easy to imagine why Stalin wished to join the war at a moment and under conditions he himself could dictate. British and French negotiators probably did not believe Stalin would make an agreement with Hitler. The animosity between the regimes seemed insurmountable. When it came, then, the Molotov-Ribbentrop Pact was a profound shock to Western politicians.

A look at Soviet periodicals from 1939-41 show that, originally, the Soviets reacted to the outbreak of war with relative calm. Only in May and June 1940, when the British evacuated to England after their defeat at Dunkirk and France capitulated, did things change and the Soviet leadership likely realize the consequences of its isolation. It began rapidly enlarging and reinforcing the Red Army command, increased demands were placed on workers, and diplomatic actions aimed at regulating the relationships between the USSR and Germany were intensified, as well. The Soviet leadership decided the new conditions warranted openly seizing the Baltic states, and the government of Romania was also given an ultimatum to sign over Bessarabia and North Bukovina to the USSR. The Soviets also tried to reinforce their presence in the Balkans, what irritated

229 See, e.g., Suvorov Viktor, Ledokhod: kto nachal vtoruyu mirovuyu voynu, Moscow, Novoye vremya, 1992; also Suvorov V., Den - M, kogda nachalas'vtoraya mirovaya voyna. Moscow, Vse dlya vas, 1994. 
Germany. ${ }^{230}$ Other rash actions taken by Soviet politicians at that time include an attempt to expand the territory of Leningrad at Finland's expense. This was accompanied by an effort to install a 'people's government' in Finland, which prompted the League of Nations to expulse the USSR and led to the deterioration of Soviet relationships with its potential allies Great Britain and France. In the end, the Soviet attack on Finland turned into the several-months-long 'Winter War' of 1939-40. The USSR achieved the change of borders it had wanted, but at the cost of a high number of casualties and a substantial blow to its prestige.

The efforts of the Soviet leadership to reinforce the country's position against Germany were therefore counterproductive, and the same applies to Stalin's efforts to compromise with Hitler. Hitler had decided to wage war against the Soviet Union as early as the summer of 1940 . He believed that by defeating it quickly, he would open the door to defeating or neutralizing Britain. Molotov's attempts in autumn 1940 in Berlin to postpone the conflict came up empty-handed. In mid1940, Hitler formalized his decision to attack the USSR in a guideline labelled 'Operation Barbarossa', and German troops began to concentrate in the area of Poland and the Balkans. ${ }^{231}$

We have noted the contradictory information Stalin had received from intelligence services. In April 1941, Winston Churchill warned Stalin that he had heard from a reliable source the Germans would attack. Stalin did not trust Churchill: he suspected mischievous motives. This distrust was supported by the 'escape' of Rudolf Hess to Britain, where Stalin considered an attempt to negotiate a BritishGerman agreement. ${ }^{232}$

There are a number of clues that suggest both Stalin and the Soviet General Staff overestimated the Red Army's abilities. Their plans counted on a potential German attack, but not on extensive military operations within the USSR. ${ }^{233}$ Oxford historian Gabriel Gorodetsky states that Zhukov and Timoshenko, like Mikhail N. Tukhachevsky before them, believed the Red Army would be able to withstand the strike and return a counteroffensive. Soviet war plans also incorporated grave miscalculations. They thought the German army would strike South of Brest-Litovsk in the direction of Ukraine, and it is here they concentrated the key Red Army troops. They were to respond in a counterstrike in the direction of Lublin and Cracow. Another contingent of Soviet troops was to

230 Bojko O./Gonec V., Nejnovější dějiny Ukrajiny, pp. 139-141; Istoria Rossii XX vek 1939-2007, ed. A. B. Zubov, Moscow Astrel'/ AST, 2000, pp. 18-20.

231 Gorodecky G., Rokovoy samoobman (pp. 100-106).

232 Rauch G.v., Geschichte der Sowjetunion, pp. 353-354.

233 Erickson J., The Soviet High Command, pp. 575-577. 
protect the Baltic area and Leningrad and counterstrike in the direction of East Prussia. Its positioning, though, did not allow adequate protection of the central front, the key target for the attacking Germans. Nor did Soviet plans count on the rapid deployment of German troops, being based instead on Stalin's careful mobilization measures and troop transfers toward the borders so as not to give the other side an excuse to start the war.

Soviet troops in the direction of Minsk, Smolensk and Moscow were weakened, as they were to the northwest in the Baltics and Leningrad. Troops were transferred to the border zone but were not placed at combat readiness, and they were not ready to provide stalwart resistance against the enemy from the very first moment. ${ }^{234}$ Adding to the difficulties were problems mobilizing and transferring Soviet troops for the border. Approximately 3 million Soviet soldiers were concentrated at the border, but at the beginning of the war, the Soviet army consisted of 4.8 million soldiers, with another 900,000 in special units. ${ }^{235}$ The German army, by contrast, had not only been mobilized and transferred to the border, it had acquired the experience and self-confidence it needed from prior battles in Europe. The Soviet leadership tried to mitigate these disadvantages by forming a second line of defence in the hinterlands for both freshly mobilized troops and those retreating from the first line. ${ }^{236}$ But many of the newly created units were deployed at the shifting front, and they suffered significant losses without having had the opportunity to seriously impact war operations.

German troops thus moved rapidly forward, surrounding large military units and even entire battalions on the front. In October 1941, they advanced to the immediate environs of Moscow, occupied the Baltics, and encircled Leningrad in a blockade. Near Kiev, they surrounded a large portion of the Soviets' southwestern front, and the Soviets suffered the irreversible loss of 615,000 soldiers,

234 Gorodecky G., Rokovoy samoobman, pp. 154-156; Abaturov V., Morozov M., Portugalsky P.: Strashnaya tsena pobedy: Neizvestnyje tragedii Velikoy Otechestvennoy. Moscow, Yauza-EKSMO, 2010, pp. 12-15.

235 See Rossiya i SSSR v voynah XX veka, 245; According to Hildermeier M. (Die Geschichte der Sowjetunion, p. 602), the Germans and their allies entered the war with 4.2 million soldiers compared to 2.9 million Soviet soldiers at the front.

236 Two lines (echelons) were expected to be spread $100 \mathrm{~km}$ deep and reserves from 150-400 km deep, see Geller M. / Nekrich A., Utopia u vlasti, p. 405; also. Rzeshevsky O. A/Suchodeyev V. V., Marshal A. M. Vasilevsky i delo vsei yego zhizni, in: Novaya i novejshaya istoria, No 3/2005, 5. 
with total losses amounting to 700,000 people. ${ }^{237}$ The Germans occupied Kiev, Kursk, Belgorod, Kharkov, the south-western portion of Donets and a large section of the Crimea, and blocked navy fortresses in Odessa and Sevastopol, the key base of the Soviets' Black Sea navy. By 4 December 1941, Soviet casualties had exceeded 3.5 million men, 2.6 million of them irreversible, and the situation was becoming hopeless. ${ }^{238}$ Approximately 45\% of USSR residents, 55 to 85 million people, lived in the occupied territory or territories under immediate threat of occupation. One-third of industrial production, $62.5 \%$ of coal mining areas, two-thirds of metallurgical production, and $60 \%$ of aluminium production were based in these territories. And the Germans held up to $47 \%$ of the arable land and $41 \%$ of the railway track. It is no wonder that Britain and the United States did not believe the USSR could withstand the Nazi attack, and the Soviet leadership was not so sure about it either. ${ }^{239}$

\section{Consolidation of the Soviet Leadership and Command}

The rapid progress made by German troops within Soviet territory prevented the Soviet leadership and its military command from gaining a clear view of developments. Prior to the war, Stalin had practiced an offense-based war mentality. He was shocked by the rapid inroads the Germans were making. When, after a week of fighting, it became clear that the General Staff did not have reliable data on the war, Stalin is said to become depressed, making his celebrated statement, 'Lenin left us a great heritage and we, his successors, have let it turn to shit." ${ }^{240} \mathrm{~A}$ five member State Defence Committee (GKO) was proposed by V.M. Molotov and L.P. Beria, consisting of themselves, G. M. Malenkov, and K. Ye. Voroshilov

237 Irreversible losses include the dead and captives; total losses also includes people who could not be redeployed due to mutilation or serious injury.

238 See Rossiya i SSSR v voynah XX vieka, pp. 249; 249 and 265 - indicate two different types of losses; Yu. Polyakov (in: collection Lyudskie poteri SSSR v period vtoroy mirovoy voyny: Sbornik statey, St. Petersburg, Blic, 1995) refers to the significant difference between Soviet and German data on the number of captives (p. 14).

239 Erickson J., The Soviet High Command, 628; Utkin A. N., Vtoraya mirovaya voyna, Moscow, Algoritm, 2002, pp. 194-195, 198-200 and 227. Later statistics indicated fewer urban dwellers in the unoccupied territory of the Russian Federation (see Naselenie Rossii v XX veke, Vol. 2, p. 82).

240 Khrushchev N.S., Vospominaniya: Izbrannye fragmenty, Moscow Vagrius, 1997, p. 239; also see Mikoyan, Anastas:Tak bylo:Razmyshlenia o minuvshem, Moscow, Vagrius, 1999, 390. 
in addition to Stalin. K. Voroshilov was later replaced by A.Mikoyan. ${ }^{241}$ Thanks to this committee, the initial disorientation was overcome and unified control of the state was insured. ${ }^{242}$ This became even more true when Stalin took over command at Headquarters. He did not have the knowledge needed to manage combat operations, and heavy losses of both territory and troops in the first months of the war were said to result from his incompetent interference. But the fact that a unified will drove both the army command and the leadership of the country was key. It allowed the war to be managed in a more flexible way, and backup positions began to be constructed.

These changes were also influenced by Stalin's lack of confidence in the reliability of his officer corps. We have spoken of the heavy losses suffered by the Soviet armed forces during the purges of the 1930s. During these purges, Stalin renewed the institution of political commissars to mind the officers' trustworthiness. The institution was later abolished. But after the crushing defeat of 1941, it was brought back to life and, in various forms, it controlled all levels of the military command. Commissars were subordinate to the political administration of the army, which operated as a department of the VKS/b Central Committee and, on higher levels, were subordinate to the party leadership and directly to Stalin himself.

After the 1937-38 purchase, the army felt an acute lack of experienced, stable commanders. Commanders were being chosen from people whose only combat experience was in the Far East, or in the Spanish civil war, or the 'Winter War' with Finland in 1939-40. They included the generals Georgy K. Zhukov, Aleksandr M. Vasilevsky, Nikolai F. Vatutin, Semyon K. Timoshenko, and a number of military district chiefs. These people did respect Stalin as the highest authority in the country, but they did not have past ties to him and hadn't had the opportunity to show their mettle. ${ }^{243}$ Initially, Stalin appointed the 'old road warriors' from the civil war-K. Ye. Voroshilov, Semyon M. Budyonny, and Semyon K.

241 See Reiman M., Poválečné konflikty a rivality na sovětské špici: Sovětské dějiny $v$ nových dílech ruských autorů, Soudobé dějiny 4/2000, pp. 547-552.

242 Gor'kov Yu., Gosudarstvenny komitet oborony postanovlyaet, pp. 19-20.

243 The rapid rise of Andrey A. Vlasov, who did well during the fight for Kiev and at the defence of Moscow, may serve as an example. He was appointed commander of the $2^{\text {nd }}$ Army who was to break the siege of Leningrad. When his army was surrounded, Vlasov gave up. He became the commander of the so-called RLA (Russian Liberation Army) and was executed in the USSR after the war. See Richter K., Prípad generála Vlasova, Prague, Panorama, 1991; also Geller M. / Nekrich, A.Utopia u vlasti, pp. 475-480. 
Timoshenko, making them the chief commanders in charge of the three basic strategic directions: the northwest, the centre, and the southwest.

Characteristically, the lack of success in the war found reflection in Stalin's repressive acts. He blamed his generals for his own mistakes and failures. The bestknown case, from 1941, was the trial of General Dmitry G. Pavlov and members of his staff, who were charged with failure to act and wilfully freeing positions for the enemy. The verdict was death. Also arrested and tortured was General Kirill A. Meretskov. He had been Commander of the Soviet General Staff in 1940-41, and later, during the Great Patriotic War, was a leading commander at the front.

General Pavlov's case centred on a diversionary tactic by a German commando which resulted in commanders at the front losing contact with their units on the very first day of the war. Pavlov and his staff had no choice but to try to restore the cohesion of the front by renewing the front lines. ${ }^{244}$ Doing so made him inaccessible to Stalin and the General Staff in Moscow. But Pavlov was not able to control the situation; most of his units were surrounded at Minsk, with 341,000 irreversible losses, amounting to roughly $55 \%$ of the total combat force, with total losses of $415,000 .{ }^{245}$ But the real issue was not a series of isolated mistakes by Pavlov and his staff. Rather it was that the General Staff did not precisely estimate the position of the front nor what action should be taken there. And this was not the only such case. Stalin caused a large section of the south-western front to dissolve at Kiev because timely information was not provided about leaving positions that could no longer be defended. Most commanders in the Soviet air force found themselves in a similar situation when they failed to receive orders to act against the attacking German air force. ${ }^{246}$

But neither overcoming Stalin's military and strategic mistakes nor consolidating the relationships between generals and the High Command were decisive for the war turning in the country's favour. Of key importance was the fact that Hitler and his generals were unable to force the USSR to capitulate. This German failure occurred not only because of the growing resistance of Soviet troops, but also because Stalin and his circle decided to hold their ground. In the autumn and winter of 1941, German army reserves in Moscow shrank significantly and

244 Danilov V.D., Stalinskaya strategia nachala voyny: plany i realnost', in: Rossija XX viek ed. Afanasjev Yu. N., (pp. 144-155), ibid the text of the corresponding document (pp. 175-183).

245 Rossia i SSSR $v$ voynach, pp. 267-268.

246 Pechenkin A. A., Poteri sovietskogo generaliteta v period Velikoy Otechestvennoy voyny (22.6.1941 g.-9.5.1945 g.), in: sb. Lyudskie poteri SSSR v period vtoroy mirovoy voyny, pp. 101-102. 
the short term blitzkrieg was transformed into a long-term war. Major roles were played by the quality of troops and technology, as well as by transport conditions, the weather and the terrain. Hitler had also overestimated the dislike of the USSR's citizenry for the Stalinist regime. The people were repulsed by Hitler's racism and the brutal way it was reflected in the war and the Nazis' relationship to civilians. There was also a strong patriotism factor in Russia, Belarus, and eastern and southern Ukraine. Even in the first year of the war, which the Germans prosecuted very successfully, their loss of troops and materiel was substantial. ${ }^{247}$ The German troops around Moscow did not possess the numerical or technological superiority to ensure their victory, and they lost three times as many troops here as in Western Europe and Poland combined. 27,000 were lost in the German officer corps, a figure that, in 1941, was five times the loss suffered in 1939-40. ${ }^{248}$ The German attack on Moscow was postponed for approximately a month in favour of an action aimed at destroying the Soviet positions at Kiev. This gave the Soviet leadership time to move its Siberian divisions to Moscow. At this point, the severe Russian winter, with temperatures oscillating around $-30^{\circ} \mathrm{C}$, set in. The Red Army was naturally more adept at dealing with these conditions, and did so more successfully than the Wehrmacht.

\section{The 1943 - Turning Point of the War}

The turn in the war's course that took place in Moscow in early December 1941 caught the German leadership off guard. It had been preceded by the Soviet army's debacle at Kiev, as well as at Vyazma and Bryansk, where German troops surrounded the forces of the Soviet Western and reserve fronts. Soviet losses amounted to sixty-four infantry divisions, eleven tank brigades, and fifty tank artillery regiments. As many as 660,000 Soviet soldiers were captured, with the total loss of life approaching one million. ${ }^{249}$ The path to Moscow seemed wide

247 For detail see Boog / Förster / Klink/ Müller/Ueberschär, Der Angriff auf die Sowjetunion, pp. 246-268.

248 Utkin A.N., Vtoraya mirovaya voyna, pp. 248-250.

249 Soviet sources (see Rossia i SSSR v voynach XX veka, p. 273) indicate losses related to the Moscow defence operation as follows: (30.9-5.12.1941): irreversible - 514,000 ( $41.1 \%$ of soldiers), health damage $-144,000$, a total of 658,000 . But losses in the Smolensk operation are separate, with irreversible losses at 486,000 (83.6\% of soldiers), out of a total 760,000 (pp. 271-272). Viz. also Roberts G.: Stalin's War: From World War to Cold War, 1939-1953, Yale Univ. Press 2008, pp. 80-81. 
open and on 15 October 1941, Stalin ordered the city evacuated. ${ }^{250}$ Foreign embassies hastily moved to Kuybyshev (now Samara) along with the Presidium of the Supreme Soviet and the government of the USSR. ${ }^{251}$ In Moscow, a state of siege was declared and General Zhukov took over command of the city's defences.

The outlook seemed grim. But in early December 1941, Soviet troops were ready to launch a counteroffensive. They succeeded in pushing the Germans back $160-320 \mathrm{~km}$, sparing Moscow from immediate danger. ${ }^{252}$ This significantly improved the mood of the Soviet leaders. The success after previous hard defeats lulled Stalin and some Soviet generals into overestimating their own potential. A directive written by Stalin to the army councils at the fronts in early 1942 claimed the new situation made it possible to drive the Germans 'relentlessly' westward, forcing them to exhaust their reserves, and opening the way for 'completely crushing Hitler's troops before the end of 1942.253 The letter was based more upon wishing that upon a sober assessment of the balance of forces. A try was made to break through the Leningrad blockade but failed, as did an attempt to reconquer the Crimea, where the Red Army lost up to 175,000 men at Kerch alone. The Germans were able to conquer Sevastopol and the Crimea in its entirety in early July 1942.

But that was not the end of it. In mid-May 1942, the Red Army began an offensive in the South aimed at conquering Kharkov. But as it began, the German command was preparing its own operation at Kharkov, and was thus able to surround and scatter three Soviet armies, which suffered total losses of 280,000, 170,000 of those irreversible. ${ }^{254}$ But in a queer twist of fate, the Kharkov conflict proved useful for the USSR, delaying German progress in the march to the Volga and the Caucasus and giving the Soviet command time to ready its defensive line at Stalingrad. ${ }^{255}$ The Soviet command was also able to prevent German attacks in the densely populated northern, central Russian and the central Volga regions, sparing these economically important areas. Soviet brigades retained

250 Rauch G.v., Geschichte der Sowjetunion, pp. 365-367; Saul N. E., Friends or Foes? The United States and Soviet Russia, 1921-1941, Univ. Press of Kansas, 2006, pp. 379-389;

251 Geller M./Nekrich A., Utopiya u vlasti, pp. 417-419 Vestnik Arkhiva Prezidenta Rossiyskoy Federatsii, Vyjna: 1941-1945, ed. Kudrjashov S., Moscow 2010, p. 82.

252 Vestnik Arkhiva Prezidenta, Voyna: 1941-1945, doc. 33, 82.

253 Geller M./ Nekrich A., Utopiya u vlasti, p. 420.

254 See Rossia i SSSR v voynach; XX vieka, p. 278.

255 Rauch G.v., Geschichte der Sowjetunion, p. 374. 
their strength to the north of the progressing German units and later surrounded the German troops at Stalingrad.

The immediate consequences of the defeats the Soviets suffered in the spring and summer of 1942 were nevertheless burdensome. Although Germany had lost the opportunity for offensive operations along the entire length of the SovietGerman front, in the South, the Soviet front began once again to fall apart. Men abandoned their positions and deserted. The leadership reacted once again by exacting heavy punishments. But for most inhabitants of the Soviet Union, particularly those of Slavic origin, it became clear that it was more than just the regime whose existence was threatened. Also endangered was the country's very statehood and its national life. This perception was exacerbated by the ruthlessness of Nazi policy in occupied areas. Soviet anti-German propaganda also left its mark: the Soviet leadership involved the Orthodox clergy and strived to revive the traditions of Russian statehood and Slavic solidarity. ${ }^{256}$ People in the cities and those in industrial occupations worked from dawn to dusk and usually through the night, as well. The key factor reinforcing their patriotism was not propaganda, though: it was the mobilization of 36 million people in the army. Most Soviet families therefore had members on the front, feared for their lives, and were willing to do their utmost. ${ }^{257}$

Negative aspects of the war mobilization were the acts of repression carried out against those who had panicked and allowed the front to disintegrate. Stalin's Order Number 270, dated 16 August 1941, forbade both commanders and soldiers from retreating from their positions on their own prerogative, and ordered both the military and governmental agencies not to leave anything behind that might be used by the enemy. Commanders were ordered to fight 'until the last man. ${ }^{258}$ The order, also signed by G. K. Zhukov expressly ordered the elimination 'by all ground and air means' of any captured Red Army commanders or soldiers, and ordered their families be deprived of support. ${ }^{259}$ The logic was that

256 Werth N., Istoriya sovetskogo gosudarstva, 1900-1991 (translated from the French), Moscow, Progress-Akademiya, 1994, pp. 319-320.

257 According to Istoria Rossii XX viek (Zubov) (p. 61) 34.4 million men and 1.2 million women were mobilized: a total of 36 million. Men aged 14-65 and women aged 16-55 were mobilized for industry unless drafted into the army.

258 See Nashe otechestvo, Vol. 2, pp. 402-403, Summary report NKVD dated 9 October 1941 indicated that up to 657,000 soldiers had been caught behind the front see Lubyanka:Stalin i NKVD-NKGB-GUKR “Smers" 1939-mart 1946. Dokumenty. (ed.) Chaustov et al., Moscow, MFD, 2006. pp. 658-660 and 317-318.

259 Istoriya Rossii: XX vek 1939-2007, (ed.) A. B. Zubov, 103. 
being captured, regardless of the circumstances, was a military betrayal, and the families of missing soldiers became hostage to the 'lapses' of the captives. But the saddest thing about these decisions was that fallen soldiers in rapidly retreating Soviet units who remained unburied were frequently registered as 'missing', another words, as captives. NKVD members assigned to individual units were an important element in permitting acts of repression on the front. They functioned as counterintelligence agents and were later (in April 1943) singled out to form a special unit labelled Smersh, a combination of the Russian words Smert and Shpionam (death to spies).

After the Red Army's defeats of summer 1942, these repressive measures by the Soviet leadership against deserters or those who left their units were applied once again under the new Order Number 227. New penalty squads and battalions were created and deployed where conditions left little hope of survival for their members. When soldiers panicked and chaos ensued, the task of the so-called 'barrier troops' (zagraditelnyye otryady) was to stop any escape by all possible means, including shooting and the executions of the perpetrators. ${ }^{260}$

Political repression also underwent significant development during the war. At its beginning, numerous executions were carried out of political prisoners who might fall into the hands of the enemy. Gulags prisoners numbered $2.3 \mathrm{mil}-$ lion at the time, 1.5 million of which were political prisoners. The highest number arrested were seized in 1942, likely influenced by the collapse of the front in Ukraine and southern Russia. The total number of political prisoners had not increased by the end of 1944; in fact, it was reduced during the first, the third and the fourth years of the war. The gulags were no longer able to accommodate the prisoner counts they had previously - the mortality rate was $22-25 \%$ per year. ${ }^{261}$ This motivated the Supreme Soviet to release up to 600,000 prisoners from the camps and prisons, 175,000 of whom were then drafted. In the two years following, another 725,000 prisoners were let go from the camps and other prisons, and more sophisticated, i.e., more moderate, forms of imprisonment began to be used at Berias initiative, including research institutions and construction bureaus. The

260 Cf. Barsenkov/Vdovin, Istoria Rossii, p. 328. In every army corps, three to five barrier units of 200 men each were established. See Istoriua Rossii:XX viek 1939-2007, ed. A. B.Zubov, pp. 125-126. See also a study by V. S. Christoforov in Novaya i noveyshaya istoria No. 5/2010, p. 45.

261 Istoriya Rossii: XX vek 1939-2007, ed. Zubov A. B., pp. 124, 125. See too: Rehabilitaciya. Vol. 1, Moskow 2000, pp. 76-77. 
perversity of the Stalinist prison system was clear in the appeals made to the patriotic feelings of prisoners. Some were even decorated for their performance in construction or other key areas. ${ }^{262}$

This development is key, because in many places the USSR's state and economic structure was not only militarized, but also interconnected to the criminal prosecution system. The latest data show approximately 7.7 million blue-collar and white-collar workers were punished between 1941 and 1945. In agriculture, the number of those convicted reached 8.5 million, 2 million of whom were imprisoned. ${ }^{263}$

By interconnecting administration, manufacturing, ideology, and repression, the Soviet leadership developed a wide-reaching tool for its use during the war and utilized it to mobilize society in an extraordinary manner, one that compensated for potential errors in combat operations and often also for the regime's own inability to resolve the issues faced. Testimony to this is a comparison of the war losses suffered by the USSR versus Nazi Germany. Prior to the Germans' defeat at Stalingrad, the USSR's total losses amounted to 11.16 million people, 6.15 million of those irreversible. These numbers were approximately double the number of troops Germany and its allies had sent to the USSR in June 1941-5.5 million soldiers. ${ }^{264}$ Under normal conditions, casualty numbers like these would ensure the Soviet Union's loss. But in addition to the concentration of power, geography and weather conditions also played a key role. Shortly after the Moscow counteroffensive, the Soviets managed to increase war production, and by late 1942, the USSR's production significantly exceeded that of the Germans. ${ }^{265}$

The forms taken by Stalin's repression included POW camps, work deployment, and the punishment of captives for war crimes committed in occupied areas. Members of special units such as the SS and the Gestapo were essentially presumed guilty from the outset. The number of captives from the German army or armies of Germany's allies increased from the time of Stalingrad, culminating at the end of the war. Prisoners were usually deployed to repair wear damage done to companies, housing units, and roadways. By the end of the war, German experts in production and in-demand technology were also actively sought.

262 See Nache otechestvo, Vol. 2, pp. 418-419; in more detail G. Ozerov, Tupolevskaya sharaga, Frankfurt/M, Posev-Verlag, 1971.

263 Rossija: XX vek 1939.2007, A. B. Zubov (ed.), p. 124.

264 Rossiya i SSSR v voynach XX vieka, p. 219 and 263.

265 Werth N., Istoriya sovetskogo gosudarstva, 1900-1991 (translated from the French Histoire de l'Union soviétique. De l'Empire russe à la Communauté des États indépendants, 1900-1991) p. 311; cf. Rossiya i SSSR v voynach XX veka, pp. 471-472. 
Noteworthy is the fact that the Soviets treated German captives much better than the Nazis treated Soviet captives, which is remarkable given the atrocities to which the Soviets subjected their own citizens. 85\% of German captives returned home, and the same holds true for captives from Germany's allies. Approximately $14.9 \%$ died in captivity. Out of the 4.5 million Soviet captives (some sources indicate more than 6 million), only 1.83 million, $40 \%$, came home. Up to 2.5 million-55\%-died in captivity. ${ }^{266}$

\section{Stalingrad and Kursk}

Despite the fact that until late 1942 it seemed certain the Red Army would continue to suffer defeat, the turnaround that came certainly cannot be written off to chance. The Soviet command was able to maintain its army at approximately 6.6 million soldiers, while the Germans had approximately 6.2 million on the Soviet front, and their numbers were shrinking. Once abandoned enterprises had been retooled to suit, Soviet industry was able to rapidly produce the materials needed to wage war. In the second half of 1942, the Red Army outdid Germany and its allies in the number of heavy weapons it had available. For the time being, though, the ratio of forces favoured the Germans in south-eastern Ukraine and southern Russia to a greater extent than the information above would indicate. ${ }^{267}$

Combat operations in early 1942 were strongly impacted by the Soviet generals' continued lack of experience and mistakes. After the Kharkov operation in June 1942, the Soviets anticipated the Germans would attack from Orel, continuing through Tula towards Moscow, or from Kursk and Voronezh northwards, with the intent of surrounding Moscow. ${ }^{268}$ But the actual attack unfolded otherwise. The Soviet front was broken the Don and Seversky Donets rivers, and the German troops and their allies-the Italians, Romanians, and Hungarians-attacked Stalingrad. This wedged open the Soviet front and Soviet troops retreated. It was then that Stalin issued the Order Number 227 noted above, and simultaneously made changes to the command staff at the front.

266 Rossiya i SSSR v voynah XX veka, p. 511: approximately 180,000 Soviet captives remained abroad after the war.

267 Barsenkov/Vdovin, Istorija Rossii, p. 629. The situation in industry is detailed on pp. 333-334; Geller/Nekrich (Utopiya u vlasti, p. 425) indicate approximately two million soldiers on each side of the Stalingrad conflict. Weapon balance: tanks and mobile artillery 1.4:1, canons and mortars 1.3:1, airforce 1.1:1 - mostly in favour of the RA (p. 437).

268 Geller/Nekrich, Utopiya u vlasti, 425; A. Utkin, Vtoraya mirovaya voyna, pp. 383-384. 
The outcome was also decided by Hitler's gross miscalculations in the war. He shifted the German offensive to the southeast, thereby allowing the Soviet command to regroup forces and move them to the Volga. At the same time, he enfeebled the march toward Stalingrad when he sent some of the troops south to create an opening to the Baku oil fields. The Caucasus was a very formidable natural obstacle. Had the Germans crossed the Volga at Stalingrad, it would've opened an extensive area in the South Volga Basin, territory that was difficult both in terms of transport and militarily, and that had little economic potential. Any attempt to direct the army to the north and northeast into the densely populated area of the Volga region would come face-to-face with the regroup Red Army. The German offensive at Stalingrad and the foothills of the Caucasus would, then, in any event likely have been doomed to failure. ${ }^{269}$

It was probably this German offensive that gave the Soviet command the idea of encircling the Germans at Stalingrad, a plan that began to take shape in midNovember 1942, on the threshold of another frigid Russian winter. The Soviet armies positioned to the north and south of Stalingrad defeated the Germans at the front on 19 November. Within five days, they had encircled twenty-two German divisions comprising 330,000 German soldiers. General Friedrich Paulus, put in command of the encircled army by Hitler, received the order to continue to fight for Stalingrad, but after weeks of hopeless battles, the Germans at Stalingrad had no choice but to surrender. Of the original 330,000 soldiers, 100,000 went into Soviet captivity. The German army and its allies have lost approximately 800,000 men at Stalingrad; the Soviets recorded half a million irreversible losses. ${ }^{270}$ The victory at Stalingrad expanded the Soviet offensive to take in the entire area of southern Russia and Ukraine, with Soviet troops conquering Rostov, Voronezh, Kursk, Belgorod, Kharkov and the greater part of the Donbas. At Leningrad, Soviet troops occupied Shlisselburg and opened a ground corridor door that allowed supplies to be shipped to Leningrad. At the central front, they pushed all the way forward to Smolensk. ${ }^{271}$

The defeat of the Germans at Stalingrad was thus a watershed event. The Soviet military command gained self-confidence and valuable experience of war.

269 Werth N., Istoria sovietskogo gosudarstva, Moscow, Progress-Akademia, 1992, pp. 307-308; Rauch, G.v. Geschichte der Sowjetunion, pp. 374-376 Geller/ Nekrich, Utopiya $u$ vlasti (p. 436) indicates that a victory at Stalingrad would have meant a victorious end of the war for Germany.

270 Rossia i SSSR v voynah XX veka, pp. 279-280.

271 Werth N., Istoria sovietskogo gosudarstva, p. 309; Rauch G.v., Geschichte der Sowjetunion, pp. 378-379 Geller/Nekrich, Utopia u vlasti, pp. 437-438. 
The loss in human life and materials was excessive, but not as excessive as before. And the Soviet army, as opposed to the Germans, could replace manpower, which allowed broad-based offensive operations to be planned.

The situation was, however, not yet stable. The German command conceived a broad plan to encircle a large number of Soviet units at Kursk. Thirty-six divisions were located there, along with significant numbers of tanks, cannon and aircraft. But the plan was no secret. Members of the British intelligence got access to key information and passed it on to the Soviets, who then concentrated their forces at Kursk. In the battle that began on 5 July 1943 the Germans failed, and their losses were extraordinary. ${ }^{272}$ Immediately afterwards, Soviet troops began an offensive in the direction of Orel-Kursk-Belgorod. The Germans were forced to withdraw from Dnepropetrovsk and their situation in the Crimea became critical. In early November, the Soviet army conquered Kiev, and the fate of Hitler's eastern quest was sealed. ${ }^{273}$

272 Barsenkov/Vdovin, Istoria SSSR, p. 332 and Geller / Nekrich (Utopia u vlasti, p. 440) indicate that this conflict involved a total (for both sides) of 2.225 million soldiers, 6,000 tanks and more than 4,500 aircraft. Soviet sources indicate 1,272,000 Soviet soldiers were deployed there. Irreversible losses amounted to 70,000 and total losses to 178,000 . See Rossiya i SSSR v voynah XX veka, p. 285.

273 Barsenkov/Vdovin, Istoria SSSR (p. 333) indicates $46 \%$ of the territory occupied by the Germans, with 41 million inhabitants, was re-onquered from November 1942 until December 1943. 



\section{The USSR and Western Allies}

\section{Connection and contradiction of the Allies}

The Soviet-German confrontation of 1941 was key, because it radically changed the USSR's international position. It made the country into one of the three leading superpowers in the anti-Hitler coalition. At the very beginning of the war, Winston Churchill, the British Prime Minister, had declared Britain an ally to the USSR, and said it would be willing to provide any aid necessary. ${ }^{274}$ Churchill made no secret of his opposition to communism, but Britain had no choice during the war with Nazi Germany. The British-Soviet agreement on joint action against Germany was signed on 12 July 1941, and contained an obligation for mutual assistance at the same time it forbade either side from negotiating separately with the enemy. After the attack on the USSR, the US State Department reacted in like manner; President Franklin D.Roosevelt issued a declaration and a promise of assistance, and later Harry L. Hopkins, his personal ambassador, visited Moscow. In late September and early October 1941, a conference of the three superpowers-the USA, Britain, and the USSR-led negotiations in Moscow on the details of the assistance to be provided. Initially, the British and American publics were not completely enthusiastic about these declarations. ${ }^{275}$ This new state of affairs was of prime importance to the USSR. That the war had initially unfolded so catastrophically for the USSR, with most British and American politicians assuming it could hold out for a few weeks at most, was unimportant. Britain itself had been pushed out of Continental Europe and did not it do well in North Africa or the Middle East. ${ }^{276}$ The United States expressed its sympathies for the USSR, but entered the war only in late 1941, and the Japanese attack on Pearl Harbor shifted its focus to the Pacific. Within the European theatre, the US remained reliant on the British in North Africa and the Mediterranean.

The USSR's alliance with the Western powers was not problem-free. The country's relationship with Britain was hampered by a lack of confidence because of their problematic relationship during the interwar period, which the outbreak

274 Geller M. / Nekrich A., Utopia u vlasti, p. 450.

275 Rzheshevsky O.A., Stalin i Cherchil': Dokumenty, kommentarii, pp. 12-15 and text of documents pp. 16-31.

276 Reynolds D., Imperskaya diplomatia, also Pozdneyeva L. V., Geopoliticheskaya diplomatia, in: Soyuzniki v voyne 1941-1945, pp. 355 and 369; Geller / Nekrich, Utopiya u vlasti, p. 450. 
of war in 1939 did nothing to change. ${ }^{277}$ Stalin's sense of distance was reinforced by the USA's isolationist position, in keeping with American tradition. From the very beginning of the Soviet-German war in August 1941, Stalin was annoyed about Roosevelt and Churchill's declaration of the Atlantic Charter, which had not been consulted with the USSR. This was reflected in Stalin's originally restrained attitude towards the anti-Hitler coalition created on New Year's 1942. ${ }^{278}$

The thorniest problem in the relationships among the Allies nevertheless revolved around issues to do with the post-war map of Europe and the post-war border of the USSR. Stalin made his attitude clear during negotiations for the British-Soviet agreement of $1941-42:{ }^{279}$ he insisted that the agreement would anchor the June 1941 Soviet border. On other issues, Stalin was more willing to compromise and seek out variant solutions. But he still made significant demands. He demanded the right to create Soviet military bases in Romania after the war, and to anchor the long-term presence of Soviet troops in Finland in the agreement. He proposed territorial and political changes that would permanently weaken Germany and its allies. Poland, in exchange for the return of eastern regions the USSR had annexed before the war (and which went to Ukraine, Belarus, and Lithuania), was to receive a greater portion of eastern Prussia-Stalin proposed East German land up to the Odra River be included. Romania was to obtain Transylvania, at that time controlled by Hungary. He also proposed to encourage neutrality on Turkey's part by promising it the Dodecanese islands and part of Bulgaria. (Turkey's attitude later prompted him to withdraw this proposal.) And finally, he was reluctant to restore the sovereignty of France, conditioning this upon the removal of the government of Philippe Pétain and the creation of a democratic system was formed the left unspecified. ${ }^{280}$

Thus, at the very outset of the war, Stalin already had clear ideas about some aspects of the post-war situation. He counted on a rapid turnaround in the war, with the United States and Britain transferring the focus of their operations to

277 Roberts G.: Stalin's War: From World War to Cold War, 1939-1953, Yale Univ. Press 2008, p. 97; also Utkin A., Vtoraya mirovaya voyna, pp. 133-134.

278 See Barsenkov/Vdovin, Istoriya SSSR, pp. 326-327; Cited according to Pozdneyeva L. V.: Geopoliticheskaya diplomatiya, in: Soyuzniki v vojne 1941-1945, eds. Chubaryan A. O., Kimball W. F., Reynolds D., Moscow, Nauka, 1995, p. 371.

279 For information on the development of American politics in relation to the USSR see Pechatnov V.O. (Stalin, Roosevelt, Truman: SSSR i SSA v 1940-ch gg. Moscow, Terra, 2006), whose conclusions we have taken into account.

280 Rzheshevsky O.A., Stalin i Čerčil', pp. 31-54 (dok. 4-9), The USA and Britain also expressed reluctance on the France issue. 
France (the second front), and a significant contribution by the USSR to the European war. But from the start of negotiations, the countries involved held vastly different positions. Britain did not want to exceed to the Soviet request for its 1941 borders to be reinstated. A key sticking point was Poland's eastern border. The USSR, Britain, and the United States were all aware that the Polish would not accept the 1941 Soviet border, and Stalin was unwilling to withdraw from the 'Curzon Line' proposed by Britain in 1920 as the ethnic border of Poland. ${ }^{281}$ Compromise solutions were difficult to come by, not only because of Poland's logically negative attitude, but also because Britain was taking over the roles France had played in Eastern Europe during the interwar period. ${ }^{282}$

The tense negotiations between the USSR and Britain continued in May and June 1942 with Molotov's visit to Britain and then the USA. The Red Army had just been soundly defeated in the Crimea and at Kharkov, and the Germans were getting ready to set out on their counteroffensive targeting Stalingrad. Soviet political leaders signed on to an agreement with Britain and the USA that prioritized the creation of a second front in the West. In London, Molotov was only able to conclude a British-Soviet Alliance Agreement by setting aside the issue of the Soviet Union's post-war borders. The second front was to be created in 1942 by British and American forces landing in the north and northwest of France. ${ }^{283}$ Winston Churchill and Anthony Eden express their doubts about the potential for its implementation, but did not outright reject the plan. Roosevelt showed interest in landing troops during his negotiations with Molotov, who upped his demands and warned that the Soviet front was in danger of collapsing. The opening of a second front in France in 1942 was thus agreed with the USA. In early April of that year, Roosevelt wrote to Churchill: 'Both your people and my people require a front be established to reduce the pressure on the Russians, and these people are wise enough to understand that today, the Russians are killing more Germans and destroying more German armaments than you and

281 See Paczkowski A., Pưl století dějin Polska 1939-1989 (from Polish: Pół wieku dziejów Polski 1939-1989), Prague Academia, 2000, pp. 43-45 and 62-63.

282 This was clearly expressed negotiations by Winston Churchill in Moscow 9-18 November 1944 that we note below.

283 The agreement was concluded for 20 years, i.e. it presumed collaboration after the war. Rzheshevsky O. A., Stalin i Cherchil': doc. 73 and 76, pp. 190-193 and 196-200; Cavlvocoressi P./Wint B.,Total war: Causes and Courses of the Second World War, Pelican Books 1974, pp. 333-334; Istoriya Rossii XX vek, 1939-2007, ed. Zubov A. B. (Moscow, Astrel'/AST, 2010, p. 68) indicates that Stalin told Molotov: “... The issue of borders... we'll address by force". 
I together. Even if full success is not achieved, a great goal will be.284 Roosevelt assured Molotov that the USA would make 4 million soldiers and 600,000 sailors available, allowing the deployment of a significant number of troops in Western Europe ${ }^{285}$ It was agreed that supplies for the armed forces, warfare materiel, aircraft, and food for the USSR should be significantly increased under the American Lend-Lease Policy.

It may thus seem that collaboration among the Allies had made great progress. But shortly after Molotov returned to Moscow, things changed. Winston Churchill left for Washington and, supported by some American generals, pushed through a proposal that the focus of war operations by the Western powers be shifted to North Africa and the Middle East, meaning the second front in Continental Europe was not created. The British and the Americans agreed to the amphibious landing operation code-named 'Torch', which was to change the balance of power on the African battlefield. In autumn of 1942, British troops headed by General Bernard L. Montgomery were able to push the Germans and the Italians out of Egypt. Shortly thereafter, American and British troops landed in French Morocco and Algeria and headed north towards Tunisia. The change in the situation on the ground in North Africa freed the Western Allies to shift their focus back to Europe, but when they did, the focus was not on France but on Italy, in an effort to force the fascists to surrender earlier rather than later.

We are not competent to assess the military aspects of these changes, but a landing in Sicily or on the Italian mainland could not replace an invasion in France. Such a landing would not attract great numbers of German forces who would have to be withdrawn from the East, easing the situation in the USSR. ${ }^{286}$ Over the long-term, it also did nothing for the positions of Britain and the USA in Continental Europe during the closing phase of the war. But the immediate consequences for the USSR were clear. After visiting Washington, Churchill travelled through Cairo before the end of April 1942 and continued on to Moscow, where he negotiated with Stalin and Molotov. His arguments seized upon the situation on the ground in North Africa and the fact that an invasion of France had not yet been adequately prepared. What was key, however, was that Britain and the USA had changed their invasion plans without notifying the Soviet leadership, and the change was not significant, since the German army was currently

284 Churchill W. S., The Second World War, Vol. IV, p. 321.

285 Rzheshevsky O.A., Stalin i Cherchil', doc. 81-86, 89, 93, 109, 111; pp. 214-233, 234-240, 242-244, 261-263, 265-266.

286 According to Geller M. and. Nekrich A (Utopia u vlasti, p. 452), up to $70 \%$ of the German armed forces were focused on the German-Soviet front. 
marching toward Stalingrad, occupying Rostov and moving toward the Caucasus. In Moscow, Churchill did not meet with much understanding. Stalin warned that the change in plans would cause the Red Army and the common interests of the Allies great harm, but he had no choice but to accept the British and American decision. ${ }^{287} \mathrm{He}$ was assured that the 'second front' would be created in 1943, and that the USSR would receive increased aid from its allies.

At that juncture, Stalin and Churchill's negotiations did not lead to open conflict. Both parties were aware of the potential consequences. In August 1942, Churchill reported to Roosevelt: "Stalin said lots of unpleasant things, particularly that we are afraid of fighting the Germans-and if we made war on them like the Russians do, we would find out it is not so bad."288 Stalin felt that he had right on his side; the unilateral decisions inspired by Churchill caused the invasion of France to be postponed by two years, and left the major burden of the European war squarely on the USSR. The ensuing losses amounted to millions of soldiers and civilians, and significant losses for the countries of Continental Europe, as well. Military operations in southern Europe were not successful enough to justify a change of invasion plans. ${ }^{289}$ The relationships between the allies now fell subject to another round of mutual distrust, which complicated subsequent agreements and their implementation.

It soon became clear that the change in invasion plans was not the only reason the dispute had arisen. In his message sent to Roosevelt from Moscow in summer of 1942, Churchill also said Stalin had reproached him that the Allies reportedly sent the USSR only 'the leftovers' that remained after satisfying 'their own needs. ${ }^{290}$ Stalin personally informed Ivan M. Maisky, the Soviet ambassador to London, that Churchill's actions in Moscow made the general impression that Churchill was counting on the USSR being defeated, and that he would then make an agreement with 'Hitler's or Bruening's' Germany. Maisky attempted to disabuse Stalin of his suspicions, but to no effect. Stalin insisted, 'Churchill

287 G.v. Rauch G.v., Geschichte der Sowjetunion, pp. 393-394.

288 Rzheshevsky O. A., Stalin i Cherchil', p. 364 (Churchill-Roosevelt, 15.8.1942); in detail Churchill W.S., The Second World War, Vol. IV, pp. 390-407. 476-502.

289 Calvocoressi P./Wint G., Total war, 338-331; Utkin A., Vtoraya mirovaya voyna, 360-361; see also Danchev A., Strategia nepryamyh deystviy, in: Soyuzniki v voyne 1941-1945, pp. 45 and 48-55.

290 Istoria Velikoy Otechestvennoy voyny Sovietskogo Soyuza, Vol. 6, Moscow 1965, pp. 48, 62 and Roberts, G.: Stalin's War, p. 205, speak of the Western Allies covering approximately $10 \%$ of Soviet warfare needs in 1941-1945. Istoria Rossii XX vek (Zubov A. B.), pp. 69-71, indicates substantially higher figures. 
succumbs easily to the influence of those who count on the defeat of the Soviet Union. The defeat of our country and compromise with Germany at the expense of the Soviet Union are the easiest way for the British to wage war against Germany.291

We have no desire to assess which party was correct. But Churchill's interference in the Allied war strategy had serious consequences. Even before the end of 1942, the Soviet army had started a counteroffensive at Stalingrad. In March 1943, Stalin pointed out to Churchill that the Allies' obligation on the 'second front' that remains unmet had allowed the Germans to transfer thirty-six divisions to the eastern front. In parallel, William H. Standley, the American ambassador in Moscow, told American journalists that the Soviet government was concealing the scope of American aid. Roosevelt was forced to send his confidant Joseph Davies, the former ambassador to the USSR, to Moscow to determine how the conflict could be settled. Although the issue was not eliminated, Davies's mission contributed to improving the relationships between Stalin and Roosevelt.

Fresh messages arrived from the Allies making clear that they had once again changed their position on the obligations and postpone the opening of the second front to 1944 . Meanwhile, up to $63 \%$ of the German army continued to be on the German-Soviet front. ${ }^{292}$ This was accompanied by a warning from Churchill that Britain and the USA would suspend their shipments to the USSR, justifying this by saying preparations had to be made for an invasion of Sicily. ${ }^{293}$ Moscow interpreted these decisions as being tied to an effort to transfer the focus of Western operations to Italy and potentially to the Balkans. The changes had taken place with no prior consultation with Stalin, which inflamed his outrage even further: 'Your decision creates enormous difficulties for the USSR, which has been fighting against the major forces of Germany and its allies for two years intensively... I need not mention how difficult and negative an impression postponing the establishment of the second front will make in this country. It leaves our army, which has suffered so many losses, without the anticipated, substantial support of English and American troops.' When Churchill attempted to counter these sentiments, Stalin added: 'I must point out to you that this is about more

291 Rzheshevsky, Stalin i Cherchil’: pp. 376, 378, Stalin to Maisky, 28.10.1942.

292 Geller M. / Nekrich A., Utopia u vlasti, pp. 451-452; also Rauch G.; v., Geschichte der Sowjetunion, pp. 403-404.

293 Perepiska Predsedatelya Sovieta Ministrov SSSR I. V. Stalina s Prezidentami SShA i Premier Ministrami Velikobritanii vo vremya Velikoy Otechestvennoy voynie 19411945 gg., Moscow, 1986, doc. 162, 163, 164, 165, pp. 130-138. 
than the disappointment of the Soviet army. It is also about the maintenance of trust with allies that has already been subject to severe tribulations. ${ }^{294}$

Such a heated argument obviously did nothing to calm the situation. To boot, in spring 1943, the relationships between the Soviet Union and its allies began to encounter new stumbling blocks. In mid-April, Radio Berlin broadcast information that the graves of thousands of Polish officers killed by Soviet security forces had been found at Katyn near Smolensk. Today, we know these murders had been carried out at the behest of the Soviet Politburo. This crime could not be explained away or excused, and for this reason, the Soviet government interpreted the information as an attempt by the Nazis to shift the blame for their own crime to the USSR, to cause a split in the anti-Hitler forces. The Polish exile government of Wladyslaw Sikorsky, however, did not reject the German accusations, and asked the International Red Cross to investigate. It was its right and duty to do so, and pressure came from the mood of a substantial segment of the Polish public, both émigrés and those at home. The request was not withdrawn even after pressure was brought by Churchill and Eden, who feared further damage to the relationship with the USSR. ${ }^{295}$ But for Stalin, the attitude of the Polish exile government served as a pretext to accuse it of aiding the Nazis. He severed his ties. His attitude became a tool which allowed the elimination of the Polish government in exile from further negotiations, thereby undermining Polish resistance to the change in the Polish-Soviet borders. ${ }^{296}$

\section{Tehran}

The conflict between allies that had originally revolved around the time and place of invasion now took on a new dimension: the post-war organization of Europe started to play a key role. After the victories at Stalingrad and Kursk, not only did the Soviets gain confidence, they realized they could bring much greater pressure to bear on their allies than before. Churchill placed British interests first, and, as we have noted, kept Stalin in the dark and, to some extent, the USA, as well. This went against the interests of the Western allies. Churchill preferred to transfer the focus of British and American war operations to Italy

294 Perepiska Predsedatelya Sovieta Ministrov SSSR, Vol. 1, pp. 131 and 135-139; Vol. II., pp. 66-68; for more detail, see Utkin A., Vtoraya mirovaya voyna, pp. 646-647.

295 Perepiska Predsedatelya Sovieta Ministrov SSSR Vol. 1, pp. 121-124.

296 See the message from Stalin to Churchill dated 4.5.1943, Perepiska Predsedatelya Soveta Ministrov SSSR, Vol. 1, pp. 126-127 and 119-124; cf. Paczkowski A., Pół wieku dziejów Polski 1939-1989, pp. 97-103. 
in the Balkans, something which might have worked but only if the USSR was incapacitated, incapable of handling the war on its own.

The negative aspects of Churchill's approach became clear immediately after Stalingrad. British politicians proved too rigid to modify their notions, and in so doing, hogtied the USA, as well. As a result, the relationships between the Western Allies and the USSR were on the edge of conflict by mid-1943. In a message sent to Roosevelt, with a copy to Churchill, Stalin stated that the Soviet government would not sign on to the decision to postpone the invasion of France made 'without its participation and an effort to jointly resolve this serious issue.' He added that the decision 'would have serious consequences for the further course of the war. ${ }^{297}$

This preliminary history of the later conferences among the 'Big Three' is worthy of our attention. The idea behind organizing these conferences was not born simply of the 'need to deepen mutual collaboration'. From the USSR's standpoint, the British and American decision-making process was discriminatory, and as such, endangered the unity of the alliance. Furthermore, the Western Allies' war strategy had not accommodated itself quickly enough to the turn the war in the East had taken, a mistake which remained uncorrected until mid-1944. In fact, this error substantially reinforced the USSR's gains from its victory at Stalingrad and Kursk, allowing Soviet soldiers to cross the Polish and Romanian borders in early 1944 and dominate the war in Eastern and Central Europe and in the Balkans. An obvious question is whether it was within the capacity of Britain and the USA to implement the war strategy that had been considered by Roosevelt in 1942. But the truth is that Britain's decisions left to the military initiative in Europe de facto up to Stalin, and the Western Allies had no choice but to adapt.

Roosevelt soon became aware that the situation had changed and, sensing the threat it posed, began to try to eliminate the tension in the relationship with the USSR. Davies's visit to Moscow presented the opportunity to do so. When he returned to the USA, Davies brought Stalin's consent for organizing a meeting involving him, Roosevelt and 'potentially' Churchill. ${ }^{298}$ But Churchill's strategy had already sunk in. Stalin realized the principle behind it was to prefer set solutions to negotiations and that the changing course of the war and the geographic distribution of combatants would allow the USSR follow this prescription much more effectively than its Western partners. His realization was

297 Perepiska Predsedatelya Sovieta Ministrov SSSR, Vol. II, doc. pp. 92, 69-70 (cit. 70), a copy was sent to Churchill simultaneously Calvocoressi; P./Wint G., Total War, pp. 333-342; Reynolds D. etc.: Soyuzniki, protivniki, potomki, in: Soyuzniki v vojne 1941-1945, pp. 423-424.

298 Perepiska Predsedatelya Sovieta Ministrov SSSR Vol. II, pp. 76-77. 
borne out in late September and early October 1943 by events in Italy. Italy's exit from the war was arranged by the Western Allies without consulting the USSR. During this episode, Stalin sent a message to Roosevelt and Churchill stating that in the future, he was not willing to simply accept the decision of his partners, and proposed that a political mission be created to prepare negotiations with German satellites now willing to exit the war. The proposal did not solve the problem, but it did serve as a warning that Stalin had taken notice of the behaviour of his allies and was determined to avail himself of the same tactics. ${ }^{299}$

The mistakes made by Western political leaders thus likely became a point of focus in Washington. The USSR's Western allies had to consider transferring their European operations, even if belatedly, to France, and to improve their positions in any potential peace talks. The initiatives taken by Roosevelt, whose own political concept clearly differed from that of Churchill, were decisive. To insist on moving from Italy to the Balkans, or across the Alps to Vienna, meant risking conflict with the USSR as well as concentrating great numbers of combatants along the front where a decisive victory was difficult to procure. ${ }^{300}$ Stalin was able to leverage these dilemmas faced by Western leaders to put through to important proposals: to call a meeting of the Big Three, and a conference of ministers of foreign affairs to take place prior to that meeting and set the agenda. The conference was to take place in Moscow, and Soviet diplomacy thus obtained a healthy opportunity to influence the negotiations of the Big Three. ${ }^{301}$

The first meeting of the Big Three-Roosevelt, Churchill, and Stalin-took place in Tehran in late November and early December 1943 and was, as might be anticipated, importantly influenced by Soviet input and proposals, which even influence the choice of Tehran as the location for the gathering. The city suited Stalin who, as chief commander of the Soviet armed forces, reportedly wished to ensure the opportunity for permanent contact with his headquarters. Roosevelt, in spite of his physical handicap (he was wheelchair-bound), and Churchill

299 Perepiska Predsedatelya Soveta Ministrov SSSR, Vol. II, doc. 104, p. 83; SSSR i germanskiy vorpos 1941-1949: Documents AVP RF, Ed. Kynin G. P. Laufer J., Moscow, Mezhdunarodnye otnoshenia, 1996, Vol. 1, p. 674, reference to a memorandum issued by the USA embassy in Moscow dated 24.9.1943 and response from NKID USSR dated 16.10.1943.

300 Contradictions continued also in 1944 and generated tension in the relationship between Churchill and Roosevelt, see Churchill W. S., The Second World war, Vol. VI, pp. 354-356.

301 Perepiska Predsedatelya Sovieta Ministrov SSSR, Vol. II, doc. 111, 89-90; Roberts, The Stalin's War, 134. 
travelled to a remote location lacking comfort and remote from their own environments. Given the safety and comfort issues, it was significant that Roosevelt accepted the Soviets' offer to stay on the grounds of Soviet Embassy-a gesture of goodwill, but one that undoubtedly gave Stalin an advantage.

Stalin's motivation for calling a meeting of the Big Three was the increased tension in the relationship between the USSR and its Western allies. Roosevelt came motivated to seek commonality for the same reason. But this was hardly an expression of Roosevelt's naïveté. The intensive development of nuclear weapons was hidden from Stalin in accordance with agreements between Roosevelt and Churchill. But the meeting in Tehran nevertheless took place in an atmosphere of unusual willingness that was lacking at both prior and subsequent negotiations between the Allies. This was emphasized in a communique from the meeting: 'We arrived here full of hope and determination, we leave as true friends in spirit and intention...'302

There is no need to examine all aspects of the Tehran conference. Most researchers today agree that the conference of foreign ministers in Moscow and the Tehran meeting initiated an eighteen month period of positive collaboration among the allies. ${ }^{303}$ These negotiations were important to the USSR because they were accompanied by a careful study of standpoints taken by Western statesmen, diplomats, and journalists. Soviet diplomacy hence came to these negotiations with much greater knowledge of Western views than ever before. ${ }^{304}$

The chief outcome of the meeting was an agreement that in spring 1944, the Western armies would land in north-western France as part of Operation Overlord. This would tie up significant numbers of German troops and immediately put German territory under threat. Other significant results of the meeting were agreement on the unconditional surrender of Germany, the opening of the postwar German border question, and the transfer of the German population. Stalin agreed with Roosevelt that an international organization should be established to replace the League of Nations. He also agreed with the creation of what later became the Security Council and proposed that it operate on the basis of unanimity

302 Teheran, Jalta, Potsdam: Die sowjetischen Protokolle von den Kriegsderonferenzen der „Grossen Drei“, hrsg. A. Fischer, Köln, Verlag Wissenschaft und Politik, 1985., pp. 89-90.

303 By this we mean the negotiation of peace agreements with "satellites" of Nazi Germany - Bulgaria, Finland, Italy, Hungary and Romania. See Ort A., Evropa 20. století, p. 133.

304 SSSR i germanski vopros, 22 iunya 1941 g.-8 maja 1945 g., Vol. 1, (ed.) Kynin G.P. and Laufer J., Moscow, Mezhdunarodnye otnoshenia, 1996, pp. 252-312. 
and joint responsibility by four superpowers-the USA, Great Britain, the USSR, and China-in the interests of maintaining peace and peacefully resolving international conflicts. ${ }^{305}$ This revealed an effort to prevent any future tensions and to create a mechanism that would involve the USSR in the system of international organizations. It is also important to note that the Soviet diplomatic service, in particular Maxim Litvinov, carefully noted that the Western Allies did not include France in the leading body of the new UN. Also noted were Churchill's statements of the 'uneven share... of the superpowers in resolving issues', prompting a corresponding change to the interpretation of the British-Soviet agreement of May 1942: 'If a border of Great Britain runs along the Rhine, it may be stated with certainty that the USSR's border runs along the Odra River, that is, along the newly established western Polish border, and this is true even if it has not been expressed explicitly. The Soviet diplomatic service also carefully noted that the interpretation saw only two of the four superpowers, Britain and the USSR, as European, and that they were to be the ones to ensure the safety of Europe. ${ }^{306}$ Ivan Maisky, another leading Soviet diplomat of whom we have spoken before, elaborated this idea by claiming that it was advantageous for the USSR to maintain a two-superpower situation in Europe. This claim relied on the fact that the influence of Britain would diminish in favour of the USA and that Britain, like France, would suffer from future population reductions.

These ideas held by Litvinov and Maisky spoke to the fact that the challenge to France's role was not simply a reflection of the current situation. A contributing factor was likely the existence of the Vichy 'state' and the reluctance of the Western allies, particularly the USA, to accept General Charles de Gaulle as the representative of a new France. Not giving France a role to play after the war was a substantial error by both the USSR and the Western superpowers, one which was remedied only later. A superpower role for friends proved essential if the Western Allies were to ensure the stability of the Western European region and anchor the western borders of post-war Germany. ${ }^{307}$ In the end, the USA and Britain decided to support France's role in Europe, allocating it an occupation

305 China as the fourth member of the "Big Three" was proposed by Roosevelt, who probably wanted stability in the Far East after the defeat of Japan.

306 SSSR i germanskij vopros, Vol. 1, pp. 210 and 283.

307 The opinion Soviet diplomats had of France as the junior partner of the victorious superpowers did not entirely conform to Stalin's political thinking: he spoke of the administration of European issues by a trio including the USA, Britain and the USSR, plus another state-clearly meaning France. See SSSR i germanski vopros, Vol. 1, pp. 338-339; also Teheran, Yalta, Potsdam, ed, Fischer A., 46. 
zone in Germany and Berlin, and pushing through French membership in the Allied Council that administered occupied Germany. The Soviet Union, for its part, established relationships with General Charles de Gaulle and recognized the role of France in Europe, complicating the future creation of a unified Western block.

However, issues of post-war organization, especially those touching on the Asian region, were not entirely resolved in Tehran. Defeating Japan did not play the role people thought it did in the discussions. Japan's defeat came with the dropping of nuclear bombs by the Americans on Hiroshima and Nagasaki, something from which Japan has still not recovered as a political and military superpower. The unilateral occupation of Japan by the Americans and the conclusion of a peace agreement in a meeting at which the USSR and, in the end, the People's Republic of China were missing made Japan's international position significantly different to that of Germany. In the long run, this proved not to be of benefit of the settlement in the Far East.

The post-war role played by China, as the victorious superpower in Asia, was not stable over the long term either. No matter the reasons, it was impossible to prevent the subsequent development of the Chinese civil war. Chang Kai-shek's regime proved to be too weak to defend its role, despite the support of the United States and Britain.

Stalin's promise to get involved in a war with Japan after the end of the European war thus had substantial meaning for developments in Asia. ${ }^{308} \mathrm{His}$ goal, though, was to reinforce the USSR's position in the Far East, to get established in the north of China, and to redeem the losses the Russians had suffered there during the Russian-Japanese war in 1905 and later, as the USSR, in the 1920s. On the one hand, Stalin accepted Chang Kai-shek as a legitimate representative of China, but he was not pleased at the prospect of turning the 'Big Three' into a 'Big Four' or 'Big Five', thereby weakening the USSR's weight. ${ }^{309}$ But Chang Kai-shek was not the only reason that China was not allowed to play the role of superpower. The Communists had won the civil war in autumn 1949 and it was this that prompted the USA and Western states to deny China acceptance as a legitimate superpower for decades. Taiwan remained in the UN as representative of China, but naturally could not pretend to the role of a superpower.

308 Teheran, Yalta, Potsdam, hrsg. A. Fischer, 68-69 and 196. Agreement on the entry of the USSR into the war in the Far East was made only in Yalta but Stalin had clearly revealed his intentions in Tehran.

309 Teheran, Yalta, Potsdam, hrsg. A. Fischer, 45-48; Utkin, Vtoraya mirovaya voyna, pp. 756-757. 


\section{The USSR and East-Central Europe}

\section{The USSR at the Countries of East Central Europe and Balkan on the End of War}

A peculiarity of the Tehran conference was that its participants touched only briefly on the substantive issues of the post-war settlement Germany. They focused their attention on issues to do with the organization of the area between the USSR and Germany, and only in this context was the issue of Germany's future addressed. The shift of initiative in the war to the USSR, whose army stood near the borders of Poland and Romania at the time of the Tehran meeting, shaped political discussion and political actions in the period between 1943 and 1945. Churchill's plans for the region, based upon a concept of federal states in Eastern Europe and the Balkans that would ensure continued British influence, were unsustainable. ${ }^{310}$ They came up against Soviet worries that a new version of the interwar 'sanitary cordon' would be created. It is difficult to agree with those who think Stalin wished to immediately begin laying the groundwork for the future Socialist bloc. At that time, Soviet thinking was vague in nature and did not extend beyond a basic framework. ${ }^{311}$ Stalin did indeed wish to create units that would allow the Soviets control over the territory, but he conceived this only as an effort to create governments in neighbouring countries which would be 'friendly' to the USSR, by which he meant governments made up of antifascist parties and organizations. He preferred communists to have a strong position, but did not treat this requirement as a litmus test. His chief emphasis was on a positive relationship between these countries and the anti-Hitler coalition, including the USSR.

Something that cannot be left out of the story is the dissolution of Comintern, which came in May 1943. The nature of its program led to its demise: through it, communist parties attained independent decision-making on political issues in their own countries, weakening their rigid dependency upon Moscow. ${ }^{312}$ At the

310 SSSR i germanskij vopros, Vol. 1, pp. 209-210 (Record of interviews between Maisky, the Soviet ambassador in London, and Eden, the Foreign Minister of Britain, 3.5.1943).

311 Cf. Sovietsky faktor v Vostochnoy Evrope 1944-195D3: Dokumenty, Ed. Volokitina T. V. Moskva, ROSSPEN 1999 Vol. 1, pp. 8-10.

312 GeorgiDimitroff, Tagebücher 1933-1943,Ed. Bayerlein Bernhard, Berlin, Aufbau-Verlag, 2000, pp. 689-696 and 700-701 (Stalin's interview for Reuter about dissolution of Comintern, 28.5.1943). 
time, the Western allies perceived the step positively, as signalling the upcoming liberalization of communism, although they insisted the USSR respect their interests and influence. ${ }^{313}$

We have no knowledge of any comprehensive concept Stalin might have had for the post-war organization of Europe and the world. But his basic notions may be distilled from his attitudes at the Big Three meeting, from his dialogues with statesmen and diplomats in the Alliance, and from internal statements he made or that were made by other leading Soviet politicians and diplomats. Stalin's concept was malleable, depending upon the evolution of the war and the changing balance of power among the Allies. Several points, however, were constants. First, he was convinced that Germany would remain the key threat to the USSR and its allies after the war. The objective then had to be to forestall any renewal of Germany's military potential. Stalin wished not only to destroy the basis of German militarism. He supported plans for its territory to be restricted and parcelled up, and the population to be transferred. But these plans were not particular to Stalin. They were shared in various degrees by other members of the Big Three, and reflected the thinking and feeling of a generation which had experienced two destructive world wars started by Germany. Stalin's own plans were based upon his conviction, once shared with his political counterparts, that left to its own devices, Germany would initiate another war of aggression over the ensuing two or three decades. ${ }^{314}$ His opinion was shared by those around him. Maisky's notes said, 'For a period of 30 to 50 years, we must strive to neutralize Germany to the maximum extent possible so that it will never again think of launching aggression against anyone.' He thought it would take 'two generations' to eliminate the war's consequences. ${ }^{315}$

Another element of Stalin's thought, that the permanent nature of the threat posed by Germany would form the basis for maintaining the coalition between the USA, Great Britain, and the USSR, is also noteworthy. He had originally conceived the USSR's post-war relationships in terms of the long-term collaboration among the countries which had been part of the anti-Hitler coalition, and was probably reinforced in this opinion by his contact with the leaders of the Allied countries, particularly Roosevelt and his administration. In many respects, Roosevelt's administration was open to the USSR, and this often made arriving at

313 SSSR i germanskiy vopros, Vol. 1, pp. 673-675, notes 101, 102, 103.

314 Cf. Stalin I., O Velikoy Otechestvennoy voyne Sovietskogo Soyuza, Moscow, OGIZ, 1946, $5^{\text {th }}$ edition p. 146 (Speech 6.11.1944); also Teheran, Yalta, Potsdam, ed. Fischer A., p. 47.

315 SSSR i germansky vopros, Vol. I., p. 335. 
compromises easy. Many Soviet documents were thus written around the notion of collaboration by the Big Three. ${ }^{316}$

This trend in thinking was more than short-term; it was also reflected in the way the post-war reconstruction of the country was conceived. This was a central point for Maisky. His proposals noted that the USSR was 'very interested in maintaining the nature of... economic relationships with the USA and Britain... It is clear that both these superpowers will play a significant role in global trade... Under certain conditions - and this is important-they may be a source of aid in the post-war reconstruction of our economy... The optimum variant for reparations will cover only a portion of our war loss; aid from the USA and from Britain thus becomes key...'

Maisky's theory was that the 'capitalist upper class' in these countries would be interested in providing aid on a commercial basis, as part of long-term loans. From the USSR's standpoint, such aid would be desirable 'under favourable conditions... based upon the Lend-Lease Act'. Economic negotiations with the Americans and Britons were to ensure the USSR would be supplied for a period of five to ten years after the war. These supplies targeted 'restoring production of the most important goods. The USA and Britain (particularly the former) will use their understanding of their obligations as allies, and the list of goods will be specified based upon the opportunities available under the Lend-Lease Act.' Maisky was aware that his ideas could only be implemented if the mutual relationships between the countries were in order. He therefore added that it was 1) necessary to ensure peace in Europe and Asia for a period of 30 to 50 years, and that 2) the USSR had to come out of the war with strategically advantageous borders, meaning the 1941 borders expanded to include Petsamo, Finland, which it had acquired, southern Sachalin, and, in the Far East, Kuril. Other wishes included a common border between the USSR and the Czechoslovak Republic, and that the requirements imposed by the Soviet Union in its negotiations with Britain in 1942 be met. The latter meant concluding agreements with Romania and Finland that would allow the USSR to build military, air and navy bases on their territory, and securing transit for the USSR across Iran to the Persian Gulf. ${ }^{317}$ Maisky's ideas on peace, however, embodied a deep contradiction, because they strove to retain long-term peace on an imperialist basis.

316 Reference is made particularly to documents prepared by Maxim M. Litvinov, Ivan M. Maisky, Jakov Z.. Suric and others, e.g., SSSR i germanskij vopros, Vol. 1., also see Reynolds etc., Sojuzniki, protivniki, potomki, in: Soyuzniki v voyne 1941-1945, pp. 425-426.

317 SSSR i germansky vopros, Vol. I., 351-352. 
The issues brought up by Maisky and Litvinov served as the foundation upon which to prepare discussions with the Allies that were to be conducted by diplomats at home and abroad known to support working with the Allies-an important point. The list of conditions for permanent peace was not particularly short, but it did not call for creating an isolated block of countries or altering the social system in the 'friendly countries'. What it did aim at was ensuring was ensuring the USSR's position as a global superpower. Maisky added that the USSR should see that the post-war regimes established in countries west of its borders were 'built on the basis of a broad democracy'. He saw the United States as a country engaged in dynamic, expansive imperialism, but in spite of this, he was also aware of the danger in straining the relationship with both it and Britain, which he preferred to continue on friendly terms. ${ }^{318}$

Here we are speaking in general terms about the Soviet conception of foreign policy. But historians cannot succumb to the temptation to consider the ideological rhetoric put forth by Stalin and his diplomats an adequate expression of the objectives that had been set. In negotiating with Western politicians, Stalin chose different words and different arguments then he employed within the Communist environment. However, it would be a gross mistake to consider his statements in the Communist environment the only real expression of his thinking. The Soviet leadership, particularly Stalin, was aware it could not push immediately for social change of the Soviet type in European countries. For this reason, other potential solutions were considered. Geoffrey Roberts noted Stalin's statements during the Yalta Conference: 'We must part with the notion that the victory of socialism may only be brought to fruition through the intermediary of the Soviet government. It may also be obtained... using other forms of state systems such as democracy, the parliamentary republic, or even the constitutional monarchy. ${ }^{319}$ Included in this was also Stalin's interest in the concept of 'socializing democracy' proposed by Edvard Beneš. Beneš presumed socialist reforms could come as part of a pluralistic political and economic system based upon an alliance relationship with the USSR while maintaining friendly relationships with the USA and Great Britain. ${ }^{320}$ Later, Stalin embodied these ideas in the concept of what he called the 'specific paths to socialism', which he promoted in

318 SSSR i germanski vopros, Vol. I., 355-356 and 359.

319 G. Roberts, Stalin's War, pp. 287-288. These ideas were independently recorded by Bulgarian communists Vasil Kolarov and Georgi Dimitrov, who was the Comintern Chairman at that time.

320 See Sovietsky faktor v Vostochnoy Evrope 1944-1953: Dokumenty, (Ed. T. V. Volokitina etc.) Moscow, ROSSPEN 1999 Vol. 1, Vvedeniye pp. 5-22. 
1946. Yelena Zubkova, the Russian author, states that in 1945-47, the Soviet leadership also considered the same pattern of socialist reform for the Baltic States, although the area had been made part of the USSR. ${ }^{321}$ That this concept was more than just a manoeuvre is probably also testified to by its becoming the subject of an international campaign, gaining numerous supporters not only among the leading communist parties, but also outside them. Later, during the 'Cold War', Stalin persecuted these very supporters as enemies.

The situation in the region was given not only by the relationships among the superpowers, but also by the internal attitudes toward the Soviet Union and Russia within the individual countries, which were frequently negative. These attitudes had been in existence since the czarist empire and Soviet policy during the interwar period hadn't done much to help. To the contrary; the annexing and Sovietisation of many countries on the eve of the war reinforced these attitudes, making Soviet dominance unpalatable to a great number of the region's people. During the war, Romania, Bulgaria, Austria, Hungary, Germany, and Finland supported Hitler and the local fascist regimes and Soviet authorities were rebuffed even when they reached out to politicians in civic parties and people of all social strata. ${ }^{322}$

In the region where the USSR gained a position of dominance, only three countries were part of the anti-Hitler coalition: Poland, the Czechoslovak Republic, and Yugoslavia. ${ }^{323}$ Geopolitically, Poland, which can hardly be described as a country friendly to the USSR, was the most important. The gap was not solely due to the obvious issues - the events of 1939 , the border, and later, Katyn-it was also the outgrowth of many years of common history. In the analysis cited above, Maisky noted: "In the past, Poland has almost always been Russia's enemy... and no one can say with certainty whether a future Poland will be a friend to the USSR." ${ }^{24}$ Poland's rejection of the USSR and the USSR's lack of confidence in the Polish civil resistance were long-term and difficult to overcome.

In Yugoslavia, some areas in particular supported friendly relations with Russia for religious, cultural, and ethnic reasons. At the governmental level, this became fully manifest only after the Communists led by Josip Broz Tito seized power. Subsequently, the relationship between the USSR and Yugoslavia seemed warm and friendly on the outside, but internally, it was characterized by hidden tension.

321 See Zubkova Jelena, Pribaltika i Kreml'1940-1953, Moscow, ROSSPEN, 2008, p. 130.

322 Geller M. / Nekrich A. Utopia u vlasti, pp. 453-454.

323 Albania wsa not considered to be an independent state and its status had not been designated.

324 SSSR i germanski vopros, Vol. I., p. 341. 
Tito could make his own decisions. On the international level and as regarded the country's internal politics, Tito took a much more radical course than Stalin recommended. In the end, this led to a long-lasting conflict between both countries.

Out of the entire region stretching from the Baltics to the Black Sea, it was the relationship between the USSR and the Czechoslovak Republic, whose government-in-exile had obtained key compromises from the USSR without hurting its friendly relations with the USA and Great Britain, that had developed most favourably. Because of this, the Czechoslovak government-in-exile initially profited most from the positive atmosphere current in the anti-Hitler coalition between 1943 and 1945. The Czechoslovak delegation, led by President Benes, travelled to Moscow immediately after the Tehran meeting, feeling positive not only about its negotiations with Stalin, but also about a number of key promises for the post-war period: 'In general, our proposals and requirements really will be supported by the Allies... The maintenance of all agreements and negotiations both with us and with Britain and America may in my opinion be expected with absolute certainty. Respect for what was promised in Moscow and Tehran to the Anglo-Saxons should not be subject to doubt. The Soviet Union considers itself a global equal, is proud of its role and position, and will not wish to abandon that,' Beneš reported after returning from Moscow. ${ }^{325}$

We mention the USSR's significant isolation in the region, because it contributed substantially to the difficulty with which compromises were reached by accelerating the conflicts which, after the disintegration of the Big Three, led to the Cold War. From 1943 on, this was most clearly reflected in the 'Polish issue', but the situations in Romania, Bulgaria, Hungary, and Yugoslavia were also affected. Stanislaw Mikolajczyk, the leader of the Polish government-in-exile, confronted though he was with the publication of information about the Katyn murders, nevertheless gravitated towards compromise with the Soviet government under pressure from both Roosevelt and Churchill. But as a member of the Peasant Party, he did not have sufficient support among those in the exile community or the resistance to effect one, and as a result, he was not able to play the role well during the Tehran conference. ${ }^{326}$ Mikolajczyk's government thus lost the chance

325 Československo-sovětské vztahy v diplomatických jednáních 1939-1945: Dokumenty, Vol. 2, červenec 1943-březen 1945, ed. J. Němeček et al. Prague, SÚA, 1999, p. 173 (Tel. report from Edvard Benes to the Ministry of Foreign Affairs dated 18.12.1943).

326 Perepiska Predsedatelya Soveta Ministrov SSSR, Vol. II, doc. 203, 214, 215, 217, 219 , 220, 223; pp. 145-146, 151, 152-153, 154-155, 156; cf. Paczkowski A., Pół wieku dziejów Polski 1939-1989), pp. 124-127. 
to establish itself in liberated Poland, where it was clear the Soviet army would be the decisive military factor. The Western Allies, unless they wished to butt up against Stalin, had to seek compromise by concession, with the end result being a Polish border that followed the 1920 'Curzon Line.'327 In the spirit of Stalin's proposals, the USSR and the West agreed that Poland would be compensated for its territory by being granted a portion of eastern Prussia and that part of Germany that lay east of the Odra River. ${ }^{328}$ Poland, though, was a sovereign state and the Big Three, particularly the Western powers, could not unabashedly dictate conditions to the Polish government without discrediting the principles of the Atlantic Charter.

The situation, then, developed as follows: In summer of 1944, Roosevelt arranged a visit to Moscow where he met with Stalin and arranged a meeting between Stalin and Mikolajczyk intended to signal Stalin's willingness to continue negotiations. Meantime, events marched on. The Soviet army crushed the powerful German army group called 'The Centre' in Belarus, broke through the German lines, and came to a halt on the right bank of the Vistula River in Warsaw. The fate of the Polish government was now an acute problem. Mikolajczyk could not reorganize the government on his own say-he was bound by the decisions of the Polish government-in-exile and the attitude of the USSR and the Western Allies. Stalin wanted to see a government with which he could make an arrangement, and he insisted that those he considered double-dealers, who played against both the Germans and the USSR, should not take part. ${ }^{329}$ Stalin argued that Poland was a key pathway to Germany and the Soviet leadership needed a 'loyal ally' that would provide a secure base. He proposed a compromise: creating the government from among representatives of the London exile and the 'Moscow Polish', with the latter being in the majority but chaired by Mikolajczyk. He further conditioned the creation of this government on a direct agreement between Mikolajczyk and representatives of the Moscow Polish. This

327 The Soviet government was willing to allow for modifications at Białystok and in the south but not to give up Lwow and Vilnjus to Poland. A. Paczkowski, Pưl století dějin Polska (from Polish: Pół wieku dziejów Polski 1939-1989), pp. 69-70.

328 See Teheran, Yalta, Potsdam: Die sowjetischen Protokolle von den Kriegskonfrenzen der "Großen Drei", Hrsg. Fischer A., Köln, Verlag Wissenschaft und Politik, 1985; pp. 7-13 (Fischer A., Einleitung and pp. 67-87; Perepiska Predsedatelja Soveta Ministrov SSSR, Vol. II., doc. 180, pp. 132-134.

329 Československo-sovětské vztahy, Vol. 2, 213. In December 1943 Stalin declared to Benes that, in principle, he did not reject a government in London but he could not allow for it to include people with clearly anti-Soviet tendencies. 
was unacceptable to both Mikolajczyk and the Western Allies. It meant establishing the 1941 borders, and establishing a government in which the majority consisted of emigrants to Moscow. ${ }^{330}$

This situation, almost impossible to resolve, saw an uprising in Warsaw organized by the local Home Army (Armia Krajowa), which acted at the bidding of the London government. The Soviet leadership was confronted with a situation in which the Polish resistance, recognizing the authority of the government-inexile, sought to occupy the Polish capital. The insurgents did not adequately take into account the Soviets' lack of touch with this government, nor its rejection of it. Mikolajczyk was in Moscow when the uprising broke out but Molotov refused to hear him out, and so Stalin was informed only during his personal meeting with Mikolajczyk on the third day of the uprising. By this time, the Soviet offensive had already come to a halt. ${ }^{331}$ Stalin promised Mikolajczyk help, but later he came to the conclusion that the uprising had been the 'criminal act of rabble-rousers' and harmed both the Polish people and the Soviet army. Stalin did not indicate the reason for his change of mind, but it must have been because the Communist resistance did not take part in the uprising. The Red Army rejoined the battle at Warsaw, but not before the uprising had been ended and the insurgents surrendered. The entire episode had a long-term harmful effect on both Poland and the USSR. Up to 20,000 insurgents died, along with 150,000 to 200,000 Warsaw residents, as the Germans systematically blew the city up. Warsaw was to disappear from the map. ${ }^{332}$

We have already spoken of the fact that historians are neither judges nor prosecutors; their task does not lie in issuing rulings. Stalin was certainly less than enthusiastic that the uprising had put him in a situation from which there was no easy way out. It is not up to us to judge whether Soviet troops could have crossed the Vistula at that point in time. Zygmunt Berling, who commanded the Polish forces approaching Warsaw at that time, did have Soviet support, but he was unable to make the crossing. The losses suffered by the Red Army in the operation that brought it to the banks of the Vistula amounted to 200,000 irreversible losses

330 Perepiska Predsedatelya Soveta Ministrov SSSR, Vol. II., doc. 218, pp. 153-154; also see Roberts G., The Stalin's War, pp. 251-260.

331 Mikolajczyk negotiated with Molotov 31.7.1944 but did not have updated information on the uprising and Molotov made it de facto impossible to discuss the topic. See Vostochnaya Evropa $v$ dokumentakh rossiyskih arkhivov, Vol. 1, ed. T. V. Volokitina et al. Moscow/ Novosibirsk, Sibirskiy chronograph, 1997, pp. 48-52.

332 Roberts G., The Stalin's War, p. 251-254; also Stalin i powstanie Warszawskie, ed. A. Przygoński, Warszawa, Gražyna, 1994. 
and 590,000 injured. ${ }^{333}$ It may thus be presumed that Soviet troops were urgently in need of a rest. The British historian Geoffrey Roberts examined in detail the veracity of statements that the Red Army had purposely come to a halt on the banks of the Vistula and rejected them. ${ }^{334}$ Around the same time, the Soviet army and Czechoslovak troops crossed the Carpathians to support the Slovak National Uprising, but without success and at the price of 30,000 irreversible loses out of a total 130,000 casualties. ${ }^{335}$

The motives that led the Polish government-in-exile and the Home Army to the uprising are clear. Nevertheless, decisions were not made on the basis of 'law' but were simply an outgrowth of the balance of power and the fact that it was at that moment unfavourable to the Polish government-in-exile. After Stalingrad and Kursk, the ball was in the USSR's court as far as the war was concerned, and the Western Allies' attitude also stabilized. In his dialogue with Benes, Stalin touched on interference in internal Polish affairs, and Benes translated what he said for Mikolajczyk: 'Do you consider us so stupid that we would wish to interfere in Polish affairs?... We just had the Moscow conference, we had the Tehran conference. We want peace for several generations. Do you think we have time to care about such things?'336 This 'spontaneous' reaction gave the impression that agreements were possible. Not only did Benes believe it-Roosevelt and Churchill did, as well. ${ }^{337}$ There is no way for us to determine in retrospect how the situation might have developed had the Polish government-in-exile accepted Stalin's offer to create a joint government with the Communists chaired by Mikolajczyk. This would likely have forced recognition of the Warsaw Uprising and made it difficult to write off as a 'criminal act by rabble-rousers'. But not much would have been changed in terms of the Soviet government's attitude to what had taken place in Poland.

The unwillingness of the government-in-exile to compromise, certainly not an even-handed approach, sharply and rapidly reinforced the power of the proMoscow group which, with the USSR's support, started to take control. The unwillingness to compromise also influenced Stalin and the Soviet leadership to

333 See Rossiya i SSSR v voynah XX veka, p. 296.

334 Meltuchov M.I., Operaciya "Bargation" $i$ Varshavskoe vosstanie 1944 goda, in: Voprosy istorii 11/04, pp. 43-57.

335 See Rossiya i SSSR v voynah XX veka, p. 299.

336 Československo-sovětské vztahy Vol. 2, p. 213.

337 Perepiska Predsedatelya Sovieta Ministrov SSSR, Vol. I, doc. 311, 313, 315, 316, 321, 322, 323; pp. 251, 252-253, 253-256, Vol. II, doc. 214, 215, 217, 218, 219, 220, 223; pp. 151-155, 156. 
believe that they did not depend upon an agreement with the Western Allies or with the Polish civic resistance to deal with the 'Polish issue'. Stalin's justification was that the Home Army fighters had not avoided armed conflicts with Soviet soldiers, and some Polish politicians pushing their own ideas did not avoid conflicts with representatives of the Lublin administration. ${ }^{338} \mathrm{He}$ also noted the danger of Polish civil war and the murder of Soviet soldiers. ${ }^{339}$ Soviet interest in compromise with the Polish civil resistance and the government-in-exile fell markedly.

\section{Churchill, Stalin and the "Percentage Agreement"}

The Polish matter was not the only thing at stake. The Soviet leadership had gained confidence that its army would be capable of occupying a significant area in eastern Central Europe and the Balkans and of penetrating into Germany. The steps it took, it took with greater confidence than before. This was reflected in Stalin and Molotov's greater focus on the unresolved problems of post-war organization in Europe and around the world. Nevertheless, given the economic and military might of the USA, which had multiplied during the war, and Stalin's resultant wish to keep healthy relationships with America and with Britain, because of its clout as a member of the Big Three, the plans for post-war organization did not turn on doctrinal considerations, nor on any effort to establish communist regimes in the occupied countries, at least not at this point.

By 1944, however, the Germans' eastern front was collapsing faster than the ability of the Allies to agree many key issues that would determine the outcome of the war and the nature of post-war developments. On the one hand, the Allied invasion of France in June 1944 allowed the movement of Allied troops to the German border; on the other, this success had come late in the war. The Soviet army was already entering Central Europe and the Balkans, and this prompted new disagreements. ${ }^{340}$ These disagreements were not only between the USSR and the Western Allies; the USA and Great Britain also had differences of opinion. They were motivated by Churchill's attitudes, which were influenced

338 Based upon the city of Lublin where originally the pro-Soviet Polish administration set up camp.

339 Teheran, Yalta, Potsdam, published by Fischer A., pp. 136-137. Stalin speaks of 212 murdered members of the Soviet army and forays attacking military warehouses. For more detail see NKVD I polskoje podpolje 1944-1945. (Po "osobym papkam" I. V. Stalina), Ed. Noskova. A. F. Moscow, Institut slavianovedenia i balkanistiki AN RF, 1994.

340 Churchill W. S., The Second World War, Vol. VI, pp. 354-356. 
by worries that the USSR's influence would grow once the USA pulled out of Europe. America's pullout from Europe had been mentioned by Roosevelt, who was re-elected for a fourth term in office around the meeting of the Big Three in Yalta in early $1945 .^{341}$

An American pullout from Europe was vital to the British but brought its problems. It placed Britain in the position of being forced to take over the representation and, potentially, the defence of Western European interests, complicated further still by the political trappings of Britain's own 'empire'. It did not feel itself competent to fulfil these roles. Churchill considered establishing France as a European superpower, saying that the long-term need to control Germany would make French assistance essential. It was at this time that the first hints began appearing in the press of a 'Western Bloc'. Churchill denied it to Stalin, but these messages were in fact one of the topics of his extensive correspondence with Field Marshal Jan Christian Smuts, whom he also introduced to Roosevelt. The time for such plans had not yet arrived, however, and France's role, given its capitulation in 1940, was still open to doubt. Churchill therefore asked himself, 'What is there left for France to win that will make the French appear to come to Germany as true victors?'342

What is important, though, is that Churchill's thoughts differed from Roosevelt's. And this was true not only as regarded the role of France, but also when it came to the issue of Central Europe and the Balkans. But their differences did not centre strictly on individual topics. Churchill was a supporter of traditional British conservatism which had a twenty-five-year history of rejecting Bolshevism and rejecting any collaboration with the USSR as a state. By contrast, Roosevelt was interested in a broadly conceived liberal conceptualization of the post-war world, a world which would be supported by the newly established United Nations, by the International Monetary Fund, the International Bank, and agreements on the post-war administration of Germany. He was against the creation of a world dominated by spheres of influence held by superpowers and came up with proposals to eliminate colonialism. In general, he did not wish a tense relationship with the USSR, but rather wished to involve the Soviets in the post-war system and to find compromises acceptable to both sides. ${ }^{343}$ This naturally does

341 Teheran, Yalta, Potsdam, Ed,. Fischer A, p. 113.

342 Churchill W.S., The Second World War, Vol. VI., pp. 244-262; G. Roberts, Stalin's war, pp. 351-56.

343 Churchill W.S., The Second World War, Vol. VI., p. 356 (particularly a letter from Roosevelt to Churchill dated 28.9.1944). 
not speak to whether his policy correctly apprehended the reality of the post-war world that arose, or whether it would lead to a successful outcome.

Current developments in the war prompted Churchill to take steps different to those of Roosevelt. One factor was that, because of their late landing at Normandy, the Western Allies had very little at their disposal with which to influence the war in Continental Europe, particularly in Central Europe. Another was that the governments-in-exile of Poland, the Czechoslovak Republic, Yugoslavia, increase operated in London, and the British had taken on obligations toward them that they could not easily shrug off. But the headway made by the Soviet army endangered the implementation of these obligations.

Because of his position in the Big Three, Churchill could not afford to generate a dispute with the USSR. Liberating Central Europe and the Balkans from Nazi bondage was at stake. Challenges like these would not only meet with a lack of understanding from the public, they would probably also lead to a parting of the ways with Roosevelt. Churchill hence tried to create a general awareness of the danger that accompanied the arrival of Soviet troops in the region, but he also sought opportunities to make a separate agreement with Stalin. He did so with Roosevelt's approval, but he had not fully informed Roosevelt what he was up to. ${ }^{344}$

The threats involved generally related to the administration of the countries into which Allied troops had marched. Stalin had initially objected ${ }^{345}$ to the British and Americans acting in Italy, but in doing so, they set a precedent, one Stalin found convenient in the end because it gave preference to dependent regimes in the countries that had fought on Hitler's side.

Expectations for the countries of the anti-Hitler coalition were otherwise: they had their governments-in-exile, exile institutions, political party centres, military units, and so on. Once the front was gone, it seemed there would be no obstacle to them taking the administration of their countries back into their own hands. But what happened in practice was different. The front passed through these countries, and the resolution of many issues was delegated to the army headquarters staff of the occupying armies. These frequently influenced the selection of people, and determined which party would be considered representatives of the antifascist regimes. This was true not only of countries occupied by

344 See Rzheshevsky O. A., Stalin i Cherchil' (Churchill): pp. 420-421 and 423.

345 Perepiska Predsedatelya Soveta Ministrov SSSR, Vol. I, doc.. 172 and 174, pp. 143-147 and 148-149. 
the Red Army but also of Greece, occupied by the British, and Italy, occupied by the British and the Americans together.

In countries occupied by the Red Army, however, things were complicated by the fact that its commanders had only a vague notion of the lifestyle of these countries, let alone such matters as the rule of law, contractual obligations, and the norms of an economic, social, and political life that were fundamentally unlike those in the USSR. The Soviet army was, in fact, entering countries with which it had had only limited intercourse prior to the war. This was naturally strongly influenced by the USSR's relationships with politicians in civic life and its potential disagreements with British or American soldiers and diplomats, both on a broad level and during negotiations at Allied Control Commission meetings.

The Soviets had originally maintained a fairly differentiated policy within Central Europe and the Balkans. It emphasized securing a power position in Poland, but left some room for compromise in the Czechoslovak Republic, Greece, and Yugoslavia, where there were communist radicals, ${ }^{346}$ and in Hungary and the divided Austria, where the door to agreement was not wide-open but not entirely shut either. From an external standpoint, the Czechoslovak Republic's position was best: the composition of its government, its territorial sovereignty and its choice of president was accepted by the Big Three, including the USSR. ${ }^{347}$ Fair amounts of room were left for economic and political plurality and for contact with the Western Allies. By contrast, in defeated Romania and Bulgaria, the Soviets followed a policy of toughness and concessions were usually superficial.

The situation in October 1944, when Winston Churchill came to Moscow, was that the liberation of the countries of Central Europe and the Balkans was not yet complete. Space for negotiation still existed. Churchill had no specific proposals in his briefcase, but he hoped that an agreement would be forthcoming on Poland that would allow for the reconstruction of its government. His efforts bore no fruit. Neither one of the two streams of the Polish resistance was willing to change its attitude, nor was Stalin willing to support a compromise that would weaken the Soviet position in Poland. ${ }^{348}$ Churchill's resistance to

346 Cf. Vostochnaya Evropa v dokumentakh rossiiskikh arkhivov, ed. T. V. Volokitina et al., doc. 151, pp. 443-463 (A record of a discussion between Stalin and B. Bierut and E. Osóbka-Morawski).

347 The exception was the case of Carpathian Ruthenia, which Stalin saw was ceded to the USSR as part of Ukraine.

348 See Rzheshevsky O. A., Stalin i Cherchil': s. 469-474 (V. Pavlov's record of discussion between Churchill and Stalin, 16 October 1944). 
the forced suppression of political opponents to Soviet policy was understandable. But Roosevelt was simultaneously telling Stalin that no government, even a Western one, would wish during a difficult war with a strong opponent to have an organized armed power outside its control causing trouble behind its back. ${ }^{349}$.

Negotiations on the Balkans were somewhat more successful. The background to them began in April and May 1944 with the advancement of Soviet troops into Romania and the worries this brought for British governmental circles. Soviet political leaders in Romania were lacking in suitable partners among their local counterparts. This fact encouraged them to negotiate with the British to try to come to an agreement between the two on both Romania and Greece. Decisive for the resolution of the Romanian matter was the Soviet attitude; for the Greek issue, it was the British attitude. But because Roosevelt had expressed his dislike for 'spheres of influence', Churchill declared the agreement interim only. ${ }^{350}$ Churchill did not make the special case of Romania and that Greece the subject of negotiations in November 1944. Rather it was the definition of the spheres of influence of the USSR versus Great Britain in the Balkans that was at issue. His proposal was specific. On a scrap of paper, Churchill proposed to Stalin that they undertake a percentage division of influence, with the USSR having $90 \%$ of the influence in Romania versus Britain's $10 \%$, and the other way round in Greece: Britain 90\%, the USSR 10\%. In Bulgaria, the ratio was to be 75\%:25\% in favour of the USSR, and 50\%:50\% in Yugoslavia and Hungary. ${ }^{351}$ In reality, this proposed percentage division on Churchill's part was a rough sketch of an open

349 In this sense, the notes Roosevelt sent to Stalin at the Yalta conference in February 1945 (Roosevelt shared many of Churchill's objections) were remarkable: "Some of the statements you made today made a big impression on me, in particular your statement that your army marching towards Berlin must have its back secured. You cannot and need not put up with any interim government which would cause your armed forces any difficulties of this kind. I would like you to know I fully realise this." See Perepiska Predsedatelya Sovieta Ministrov SSSR, Vol. II, doc. 266, pp. 185-186.

350 Kalinin A.A., Sovietsko-britanskie peregovory o razdele sfer vliyania $v$ Evrope $v 1944$ g., in Voprosy istorii 9/09, pp. 19-22.

351 The British expressed their dissatisfaction with Tito, who enjoyed British military protection on the island of Vis, for having travelled to the USSR without informing the British. They also expressed their dissatisfaction with the fact that the USSR occupied Bulgaria without being at war with it (in contrast to Great Britain) and, finally, expressed "worries" over "civil war" phenomena appearing in the "liberated" countries. By this they meant actions taken by communists and the communist resistance. See Rzheshevskiy, O. A.. Stalin i Cherchil' (Churchill), pp. 417, 420-421, 423-424 and 429-435. 
imperial barter transaction. What is remarkable is the Churchill did not differentiate between the Allied countries and the defeated Axis countries, and that he prefaced his proposal by saying that 'the Americans and their president would be shocked by such a division of Europe into spheres of influence.'352

It was a strange whimsy to go to Moscow aiming to divide up Yugoslavia, Hungary, and Albania 50-50 with Stalin-to cajole him into recognizing the British interest in these countries and, by contrast, open him to defining the Soviet influence in Bulgaria and Romania, countries which had already been occupied by the Soviet army, as $75-25$ and $90-10 .{ }^{353}$ Churchill's propositions thus confirmed the former agreements between the two countries on Romania and Greece that were not supported by Roosevelt. What is more, for Churchill they represented a carte blanche granted by Stalin for violent interference by the British in Greece. ${ }^{354}$ Behind all this likely lay a quiet agreement between Britain and the Soviet Union on dividing up spheres of influence in Central Europe and the Balkans behind Roosevelt's back. ${ }^{355}$ Such an agreement could not take effect without the Americans' consent, but it became a factor in the deepening disputes and misunderstandings that began to arise among the Big Three.

\section{Yalta and Potsdam}

The negotiations between Churchill and Stalin took place in October 1944 on the eve of the February 1945 Yalta Conference. The decisions taken there have been considered of key importance to the subsequent enslavement of many Europeans in the Soviet bloc, the dividing up of the post-war world and the rise of the Cold War. But this image of Yalta falls far short of reality. Its basic outcome was not a division of Europe, but rather contradictory tendencies to try to maintain the collaboration between the victorious superpowers-something Roosevelt wished for - and to fall into more frequent conflicts, often arising from the attitudes

352 Rzheshevskiy O. A., Stalin i Cherchil` (Churchill), p. 420 (V. Pavlov's record of discussion between Churchill and Stalin, 9 October 1944).

353 The issue of Albania popped up later and the percentage influence in Hungary and Bulgaria was changed for the benefit of the USSR.

354 Approximately one month after Churchill's visit to Moscow, the British, with no scruples, evened the score with the communist resistance in Athens and Greece. See Churchill W. S., The Second World War, VI., pp. 247, 253-265, 273-279.

355 Stalin requested that Finland be "punished" in return for a promise given to the Americans that he would not occupy Finland militarily. Stalin also managedto attain the quiet consent of the Allies to the USSR annexing the Baltics (Lithuania, Latvia and Estonia) which, however, was not recognized de jure by the USA. 
of Churchill and Stalin. The latter's approach increasingly became one of simply announcing what he had decided, while the former put forward requirements impossible to attain via any method but force.

Overall, the negotiations at the conference went well. The differences of attitude on the part of Churchill and Roosevelt did not change the reality that the USA and Britain were close collaborators, something apparent in the implementation of military operations and in politics and diplomacy. But the USSR and the Western Allies were separated from each other by prejudices on both sides, as well as mutual distrust and differences in their social systems that were ameliorated by the war but very much still present. The USSR reproached the West for its effort to win the war at the cost of Soviet soldiers' lives and worried that its gains would be taken from it once the war had ended.

The key point at the Yalta Conference was Germany's post-war fate. In the foreground was clearly the issue of its integrity. It had been agreed in principle that the eastern sections of Prussia all the way to the Odra River would be handed over to Poland, and that the national border of Austria would be reviewed, radically reducing the territory claimed by the German 'Empire'. But what to do with Germany remained an open issue. Roosevelt, who wished to decentralize its administration and power, had in Tehran been a zealous supporter of dividing the country up. Churchill and Stalin, at their meeting in Moscow in October 1944, had been much more moderate. They agreed to Churchill's proposal to divide the country into two states - a Bavarian state to include southern Germany, and a Prussian state to include the central regions and the North. The RhineWestphalian industrial region and the Ruhr and Rhineland, because of their outsize economic importance, were to become an internationally administered unit. As he later confessed, Churchill was primarily interested in postponing the 'German solution' until 'Germanophobia' had passed. At Yalta, he buried proposals for the immediate division of Germany when he indicated the difficulties that would accompany the definition of the new units' borders. ${ }^{356}$

At the subsequent Allied conference in Potsdam in July and August 1945, Ernest Bevin, the new British Minister of Foreign Affairs, supported by Harry Truman and with Stalin's consent, put through a proposal that Rhine-Westphalia was to be included in the same framework-the definitive definition of Germany's borders was to be the subject of the German Peace Treaty. ${ }^{357}$ But the other

356 Teheran, Yalta, Potsdam, ed. Fischer A., 107-109; W. S. Churchill, The Second World War, VI., pp. 440-453.

357 Teheran, Yalta, Potsdam, ed. Fischer A., pp. 352-353. 
side of the coin was that, at Yalta, preference had been given to dividing Germany and Berlin into Allied occupation zones, 'spheres of influence', whose piecemeal nature was to be bridged by the Allied Control Commission for Germany.

This division into new states never happened. The occupation zones, which were to be a short-term solution, instead became permanent reality for the next half-a-century. The allies could not agree the German Peace Treaty. Later, the division of Germany into occupation zones became the basis for the establishment of two German states, the FRG and the GDR. The decision to create these occupation zones was accompanied by an effort to establish France as one of the occupying superpowers, as well. ${ }^{358}$ The intention was clear: the issue was not so much administering Germany as it was establishing the West as a political counterweight whose power would balance the European East dominated by the USSR. ${ }^{359}$

Germany's fate was of extraordinary importance to the USSR, not only for security but also for economic reasons. The country needed compensation for the enormous losses it had suffered during the war. German reparations alone could not resolve its problems, and the original Soviet plans did not rely solely on them. Allied help, particularly American help, was to become crucial. Talks with the British in 1944 failed when neither party could agree on the loan procedure. The British had themselves suffered deeply in the war and this was reflected in their own debt levels. Originally, they like the USSR were strongly impacted by the end of American supplies under the Lend-Lease Act. ${ }^{360}$ The only way to allow for the development of Soviet-British economic relationships was to go back to everyday commercial relationships, but the British did not feel adequately strong financially or adequately politically motivated to give the USSR a loan under favourable conditions.

Similar issues also characterized the Soviet relationship with America. American supplies to the USSR under Lend-Lease expressed in dollars attain their highest level in 1944, but their quality was much lower than with supplies for Britain. They were nevertheless of great importance to the USSR, and the Soviet government relied on them being continued, given the enormous casualties and material loss the country had suffered. When Roosevelt died and Harry Truman took office in April 1945, the USA turned a deaf ear on the Soviets' difficulties.

358 Britain and the USA carved its occupation zone out of their own occupation zones.

359 The logic behind this is clear: Italy and Germany were defeated states, Franco's Spain was out of the question and Belgium and the Netherlands were not superpowers.

360 Soyuzniki v vojne 1941-1945, pp. 234-235, 237-238 and 246 (treatise by T. A. Wilson, Leviafan). 
A request for a $\$ 1$ billion loan made in February 1944 and a later request made by Molotov for a $\$ 6.6$ billion on were turned down. Both were rejected because of a lack of agreement over the conditions under which they were to be provided. ${ }^{361}$ The Americans insisted on the principle of free trade, and on the operations of the International Monetary Fund and the International Bank for Reconstruction and Development, which the USSR found unacceptable because of its economic system. Later the Americans themselves and the British had misgivings because of Soviet policy in Eastern and Central Europe and the Balkans, and the original notions of collaboration came to a conclusive demise. ${ }^{362}$

The failure of these negotiations heightened the importance of reparations to the USSR. Because of its experience with reparations after World War I, the country strived in particular to get 'tit for tat'-the confiscation of property, the disassembly and transfer of industrial facilities, railroad equipment, and so on. Another portion of these reparations were to be covered by products made by German facilities and the facilities of other defeated nations. Their total extent over a ten-year period was to reach approximately $\$ 10$ billion, but the USSR was to settle in Germany's reparations to Poland from this sum.

The Soviet Union's requirements, despite the fact that they covered only an insignificant portion of the total loss, were enormously high. A large portion of German industry was situated in the West, not accessible to the Soviets, and the industrial area in the southeast of Germany had been allocated to Poland. ${ }^{363}$ The USSR had little opportunity to extract reparations from its own occupied zone, and the Soviet leaders trying to redress the country's war losses were unaware of the true costs of occupying a foreign territory and providing for the needs of its residents, including millions of refugees and people who had been forcefully relocated. The USSR was unaware of the colossal depth of its wartime loss. It could only be compensated to a minimal extent. An agreement drawn up in Potsdam divided Soviet debts equally among other Allied occupation zones, but these were to be partially compensated by food from the Soviet zone. ${ }^{364}$ In principle, the Western Allies aimed to satisfy the greatest amount of the USSR's

361 Soyuzniki v vojne 1941-1945, p. 247. American leaders could not imagine the true extent of the material loss and casualties the USSR suffered and the Soviets were reluctant to provide them actual data on the state of Soviet economy.

362 Luňák P., Spojené státy a Západní Evropa ve studené válce, Prague, Libri, 1997, p. 54.

363 Teheran, Yalta, Potsdam, ed. Fischer A., pp. 259-268 and 401. The reparation problem was to be definitely resoled by a peace agreement with Germany which, as is well known, never happened.

364 Teheran, Yalta, Potsdam, ed. Fischer A., 395-398. 
debts from its own occupation zone, and this made the issue of reparations into a substantial source of friction between the USSR and the Allies. It complicated the economic situation in Germany and became a source of significant difficulty for the USSR during the consolidation of the situation in its own occupation zone. The Yalta Conference, intended to draw up the basis for the post-war organization of Europe, failed to meet its goals, mostly settling for temporary or provisional solutions.

The actions of both Churchill and Stalin were visibly influenced. Starting in February 1945, other events took place that significantly influenced the war's outcome. The Soviet army's rapid progress-it had leapt from the Warsaw suburbs all the way to the Odra River-came face-to-face with resistance from what remained of the German army. By contrast, the Western Allied troops were making marked gains after having defeated the Germans in the Ardennes and crossing the Rhine. By early May, they controlled a substantial section of northern and central Germany, including areas that had been earmarked for the USSR to administer under the Alliance agreements in late April 1945; moreover, German troops in Italy surrendered, thereby opening the way to Vienna and the Hungarian border. ${ }^{365}$ Those German troops which remained to defend Germany's eastern border seemed, then, to be fighting much harder than their comrades protecting central and northern Germany, and Germany's defeat seemed closer at hand. This impacted German foot soldiers and officers as well as that portion of the Nazi leadership that preferred surrender.

All of this naturally was a source of nervousness for the Soviet leadership, which worried that in the final days of the war, it would lose the substantial results of its victory. Even more unsettling for Stalin was the intelligence he was getting about American and British negotiations with Heinrich Himmler's representatives in Switzerland. ${ }^{366} \mathrm{He}$ questioned whether the Western Allies would respect the agreements, and this was not pure speculation. Though the American politicians and the American leadership mostly adhered to the agreements and arrangements that had been made, Churchill's attitudes had undergone a significant transformation. He himself later wrote, 'Our countries have lost the common enemy that was almost the sole bond between us.' In so speaking, he wished the British and the Americans-both politicians and soldiers-to know that 'Soviet Russia has become a deadly threat to the war', and that 'a new front

365 Similarly, see, e.g. Roberts G.,: Stalin's War, pp. 308-318.

366 Perepiska Predsedatelya Soveta Ministrov SSSR, Vol. II, doc. 281, 283-288; pp. 198 and 202-208. 
must be created immediately to stop its expansion. This front,' he said, 'should be as far to the east in Europe as possible.' He recommended that the Western Allies take as their main objective conquering Berlin, liberating Czechoslovakia, taking Prague, occupying Vienna perhaps all of Austria, and striking against Tito, who was preparing to occupy Terst and its surroundings. ${ }^{367}$

The impact of Churchill's proposals should not be underestimated. To Europeans of the time, they sounded far different than they do to modern ears. His contemporaries had no idea what would ensue in Eastern Europe. To them, it was not Stalin who was the chief evil, it was Hitler and Nazi Germany, and the USSR had played an undisputed role in their defeat. A sudden disagreement with the Soviet Union such as Churchill imagined might thus quickly escalate into an armed conflict, something that was unacceptable to the majority of the democratic public and which would have unfortunate consequences for Europe.

Roosevelt had died suddenly on April 12, 1945 without seeing Germany's surrender. Roosevelt was a figure of excellence in both American and world history. He initiated the antifascist coalition and was the author of a political vision which saw the Big Three as the first step in a global organization of democratic states that would be able to permanently put to rest the danger of world wars. $\mathrm{He}$ was able to connect the United States, Britain, and the USSR in both the war and a political coalition that would have been impossible in prior decades. The UN, in whose founding Roosevelt was the principal mover, included in the structure of the post-war world both the USSR and the conditions for China to take part, as well. In contrast to Churchill, Roosevelt's political methodology was not one of pressure and boycott, but rather one of negotiation and compromise. He took good advantage of the opportunities offered by the scope of America's economic and military potential, regarding the USSR's presence in Europe as a fact to be dealt with, one he did not try to reverse violently but rather to shape in such a way that Allied collaboration remained possible and the USA's influence on developments in the USSR and Eastern Central Europe was maintained. Between 1945 and 1947, though, the course Roosevelt had set for American policy was abandoned. As historians, we do not possess the tools that would allow us to determine what would have happened had this course then been followed. Its potential had not been exhausted when Roosevelt died. Will to negotiate persisted on both the American and Soviet sides, as testified to by the Soviet Union's reaction to Roosevelt's death. ${ }^{368}$

367 Churchill, W.S.: Second World War, Vol. VI, p. 522-529.

368 For detail see Roberts G., Stalin's War, pp. 323-324. 


\section{The USSR as the New World Superpower}

World War II came to an end with the surrender of Nazi Germany in Berlin in the late hours of May 8 in the early hours of May 9, 1945. With its surrender, the Soviet Union was definitively positioned as one of the three superpowers that had created the basis for the victorious anti-Hitler coalition, a surprising result when one considers the initial European and internal Soviet political and military situation as it had been in 1941. The Soviet Union was far from taking its new position for granted, but the decisive factors had been the country's size, the number of people within it, its toughness, and its ability to handle difficult situations. The crucial role the USSR had played in the European war became clear only in 1943, and the Western Allies could do little but to adjust, something visible in the minutes of the Tehran, Yalta, and Potsdam conferences and extensive correspondence involving Roosevelt, Stalin, and Churchill, dated 1941-45.

In recent years, some journalists and historians have accused the USSR of pursuing expansionist goals during the war and counting on the creation of the extensive Soviet bloc that came into being after the war. ${ }^{369}$ But prior to World War II, the USSR was not a recognized European superpower. The country had undergone a ten year period of intense industrial development, but was far from up to the task of overcoming its inherent backwardness, the losses it had sustained in World War I and the civil war, and the slow start-up of construction during the first decade of Soviet power. All this was accompanied by the losses of agricultural collectivization and the famine of the 1930s, and the systematic murder of the Soviet elite and a large share of the army command. Prior to 1941, the USSR had not been a popular choice for an ally against Nazi Germany, something shown convincingly during the Spanish Civil War and, particularly, the Munich Agreement of September 1938, in which British and French diplomats had a good chance to create a coalition to shield the Czechoslovak Republic and prevent the outbreak of World War II on the basis of an existing agreement with the USSR. But in Munich they decided otherwise: to agree with Hitler. Even

369 A statement made by Stalin and cited by Milovan Djilas has long been taken as testimony to this fact: "This war is not like the last one. Anyonewho occupies territory will also bring his state establishment wherever his army goes. There is no other way." (Djilas M., Razgovory so Stalinym. Frankfurt/M. Posev 1970, p. 108). 
afterwards there was no intensive effort to sign the USSR on as an ally against Hitler and the Axis states. ${ }^{370}$.

We have already noted the catastrophic consequences of Stalin's policies, of his poor estimation of the state of affairs on the eve of war, and his weakness in managing military operations. His ideas on the post-war organization of Central Europe and the Balkans thus began to take shape only after the USSR was attacked by Germany. Initially, Stalin had insisted that the Soviet Union's 1941 borders remain unchanged. ${ }^{371}$ In other matters, his ideas did not take shape simply or in a single step. The war with Germany had developed unfavourably for the USSR, and even after Stalingrad it was far from clear whether the USSR would have the strength and the opportunity to end the war in Central Europe and the Balkans. It was equally unclear how the Western Allies would fare in their operations to the south and later in the West of Europe, and what inroads they would make into Central Europe and the Balkans. The greatest unknown came from the USA's intention to withdraw its military from Europe once the war was over. ${ }^{372}$.

We have already said that the Soviet Union's ideas on post-war gains were not modest. But Stalin bargained without a strong hand. He resurrected his ideas during the preparations for the Tehran conference, when it became clear that the USSR would have a significant share in organizing post-war Europe. In developing his plans, Stalin took into account post-war collaboration between the USA and Great Britain; he also realised that he would have to respect the interests and notions of his allies. The effort to continue collaborating with them was based not solely on the distribution of power, but also on the scope of loss suffered by the USSR during the war, a loss which it could not adequately compensate without contributions from the USA and Britain. Stalin was also convinced that Germany would be able to regenerate its military potential relatively quickly and that collaboration between the USSR, the USA and Great Britain would thus be the guarantee of the German defeat the coming permanent. ${ }^{373} \mathrm{He}$ accepted the

370 Axis - alliance of Germany, Italy and Japan.

371 I.e., the annexation of the Baltics, Western Ukraine, Western Byelorussia, Bukovina and Moldavia which, from Stalin's point of view, probably was meant to be a return of the "empire" of lands and nations "stolen" from Russia after World War I.

372 This was the basis for Maisky's notion of the USSR as a dominant ground superpower in Europe formulated in early 1944. See SSSR i germanski vopros, 1941-1949, Vol. I, pp. 338-339.

373 Moskva $i$ vostochnaya Evropa:Stanovlenie politicheskich rezhimov sovetskogo tipa 1949-1953 (Eds)T. V. Volokitina, G. P. Muraško, A. F. Noskova, T. A. Pokivajlova (Moscow: ROSSPEN 2002), 30-31. 
composition of the UN Roosevelt put forward and the creation of the Security Council, which would anchor the superpower positions of the USA, USSR, and Great Britain even after the war. ${ }^{374}$

Thus, Soviet notions on the shape and objectives of superpower politics underwent significant changes that lasted the entire period from the Tehran conference until summer 1948, when the Allies faced a definitive conflict over the 'German issue'. Originally, a number of solutions had been put forward, although they were growing fewer in number over time. From Stalin's standpoint the decisive effort was to eliminate Germany as a power player and ensure its permanent neutralization within the European balance of power. He saw the creation of a Soviet bloc as a priority only when it became clear that an agreement among the allies on Germany was now impossible. The economic potential of this bloc did not seem substantial enough at the end of the war to be considered compensation (with the exception of Bohemia, Moravia, and Polish Silesia), although it did rise sharply later. Also problematic was the interpretation of the Soviet bloc in military terms-its chief function was as a buffer zone for the USSR should a military confrontation with the West occur. ${ }^{375}$.

The biggest sticking point in forming the post-war Soviet zone of influence was Stalin's attitude on the Polish issue. Poland was of key importance for the USSR as the gateway that had allowed Soviet troops to remain in Germany; closing it would block an unexpected land invasion into the USSR from the West. Stalin had withdrawn his troops from the Czechoslovak Republic as early as the autumn of 1945 . He originally agreed to maintain the plurality of economic and political life, something he also permitted in Poland and Hungary, though within a fairly limited political framework. Greater independence was also given to Tito's Yugoslavia, and the foreign policy that country subsequently adopted worsened relations between the USSR and the Western Allies and, in the end, gave rise to a disagreement between Yugoslavia and the USSR itself. On an explicit request made by Roosevelt in Yalta, probably for strategic reasons, Stalin did not occupy Finland but allowed a pluralist regime that was neutral militarily and gave up many justified claims toward the USSR. ${ }^{376}$

374 Permanent members also included China and France. It was primarily Roosevelt who insisted on China's membership and Churchill who insisted on France's membership.

375 Its significance, however, depended upon potential participation in a conflict with Germany to which neither Poland or the Czechoslovak Republic were indifferent.

376 An occupation of Finland would have entailed a significant military force which would then be missing for a head-on attack. 
The novel situation of late 1943 in its own way surprised the Soviet leadership, as well. It counted on a leading role on the European mainland, but the changes that took place in the social systems of the European countries led to a protracted process whose outcome was unclear. Stalin recommended the European countries create governments out of the anti-fascist forces in combination with communists. Originally, they were to remain sovereign and opened contact with the Western Allies in spite of his intent to keep them under Soviet influence. He continued to differentiate between the defeated countries, where the occupying superpowers would determine the organization of post-war life, and countries of the anti-Hitler coalition, within which he counted on the significant role of internal political players. The abolition of Comintern in 1943 was testimony to this. It had been intended to provide foreign communist parties with more space for independent decision-making. Poland was the exception, and we have just discussed the reasons why.

These aspects of Soviet policy must be noted because they reveal the extent to which the Soviets were originally interested in collaborating with the USA and Great Britain. The real-life issues to which this collaboration and assistance provided by the Allies gave rise proved in the end to be larger and thornier than the parties had anticipated.

There was another facet of this same problem. It consisted in the fact that the USSR's share in the defeat of Nazi Germany had established it as a world superpower, but the country had never exhibited the signs one would expect of a superpower. It did not possess sufficient economic or cultural potential, and for this reason was unable to solidify its newly won position at the same time it maintained free and open relationships with the rest of the world. And its deficits were aggravated by the enormous extent of the country's wartime loss, something that has frequently been neglected in the politicized literature. 25 to 29 million people became casualties, not including those with permanent disabilities or who suffered the consequences of famine, disease, and the loss of their homes. The demographic issues were enormous: villages had been depopulated; the gender ratio had been altered and this was reflected for a long period in the birth rate; and there was a huge loss of educated people. And the loss of production facilities and cultural assets, not valued precisely but only in estimates, is another chapter altogether.

The USSR thus lacked the requisite standard of living, and proper social and cultural standards, and it therefore had no means to influence the development of countries within its interest zone over the long term. All this permanently provoked a lack of interest on the part of the USA and Great Britain in collaborating with the Soviets. The disputes that loomed so large between the USSR and the 
Western superpowers were due, then, not simply to Soviet politics, but to its being 'otherwise' in character, with a different potential. Had the country given up its superpower position, it would have collapsed after the war was won-not only its political base, but its economic and social life, as well. The Soviet leadership could hardly permit that.

The potential of Soviet influence, however, was not exhausted. We have already noted the prestige that Stalin and the USSR had obtained by defeat of Nazi Germany. This prestige had brought the country great respect both internationally and within its own borders. Millions of soldiers were now returning home, an incredible relief to a great section of the population, particularly the families of the soldiers. No longer did they need worry about the lives of their loved ones or the fate of their country; they dared hope that the war's end would bring an overall improvement to their living conditions. The victory kindled the nationalist feelings of the Russians and many Slavs living in the USSR. Numerous speeches by foreign statesmen and the statements of Stalin and other Soviet officials lauded the Russians' performance. In this way, Soviet ideology opened itself to the influence of Russian patriotism, and this influenced the process of appointment to functions and positions in institutions and organizations of the regime. ${ }^{377}$ The population's vertical mobility significantly expanded, and some soldiers, particularly officers, found the opportunity to take economic, administrative, and political functions that had come open during the war. A new stratum of functionaries and officers came into being, strongly influencing political and civic life in ensuing years. Soldiers of peasant origin and those from small towns found the door to the cities, to industry, and to construction sites open. Many former soldiers were given the opportunity to complete their education.

In all this, the regime acquired a cushion of support from people who had fought Nazism during the war. But the role that some political sources have ascribed to remaining abroad is exaggerated. Some displaced persons and soldiers did decide to stay outside the USSR's borders, but this was not a prevailing trend. Germany, Austria, and Hungary were enemy states. Furthermore, their experience in Germany during the war was adequate deterrent for most people who had been abducted and for soldiers. With the partial exception of the Czechoslovak Republic, the countries to which Soviet soldiers had marched were not among the world's most developed areas. Setting aside issues related to language, qualification, and culture, it was difficult to remain abroad in an area controlled

377 See, e.g., Stalin, O Velikoy Otechestvennoy voyne Sovietskogo Soyuza, Moscow: OGIZ, 1946), pp. 173-174. 
by the Soviet authorities, and this was true not only for army deserters but also in terms of the forced repatriation of displaced persons to the USSR. The opportunity to remain abroad was open in particular to Soviet citizens who had gotten to Western Europe during the war or to zones administered by the Allied authorities.

Most citizens of the Soviet Union therefore looked for improvements in the situation in their own country. Deeper collaboration with the allies was anticipated. The Soviet government was itself inclined in this direction at the war's end, supporting it or at least tolerating it for some time. It backed off this open approach only in 1946-47, citing a need to fight 'the influence of Western ideologies', and later, 'cosmopolitanism'.

During the initial post-war years, similar factors were present as well in the countries within the Soviet zone of interest. Their newly created governments put their supporters in positions that had formerly been held by members or collaborators of the occupying fascist regimes. This was accompanied by the transfer of assets and social reforms that influenced the mood of the lower social classes. It is also essential to note the territorial changes that took place, along with changes in national demographics that resulted from novel state borders and displaced German inhabitants. Finally, the gates of the prisons and concentration camps were opened and the knowledge of what had gone on there became a significant influence.

The conflicting post-war developments that led to the mutual alienation of the USSR and its Western allies saw a big role played by the countries of western and southern Europe and of Asia, where politics shifted leftward and the mood became decidedly anti-colonial, leading to the increased influence of left-wing parties and organizations. In Europe, this was particularly true of France, Italy, and Greece. The USSR's wartime performance generated anxiety when the country's influence and potential was overestimated, and these worries were a substantial factor behind the Truman administration's decision not to withdraw the Americans who had stayed behind.

This forced the USA into a paradoxical situation. On the one hand, the Soviets exerted strong pressure for the USA to help compensate their war loss. On the other, the populace wished to see the USA serve as a counterbalance to Soviet influence and allow European social systems to stabilize. These conflicting demands balanced by the Americans and to some extent the British were made more acute by the continuous clashes over approaches, systems, and mentality between the USSR and the Western Allies. These constant conflicts were aggravated by ingrained aversions and antagonisms that the Allies had accumulated during the pre-war, wartime, and post-war periods. Mutual distrust grew. Part of it stemmed 
from the Soviets' unwillingness to reveal the actual state of the country to the Allies, who would then be able to see that the USSR's leaders lacked the wherewithal to back up their ambitions. Compromise became difficult; the unity which had been anticipated when the objectives were drawn up for post-war Allied policy was dissipating.

The new situation gave rise to new worries about Soviet expansion. Recent literature has made frequent note of the alleged threat posed by the Soviets to Greece and Turkey and later Soviet claims in the Mediterranean and Asia. ${ }^{378} \mathrm{Al}-$ though Stalin introduced most of these claims and 'wishes' in his negotiations with the Allies, they touched on sensitive points in the mutual balance of power. The Soviet claims were mostly probes. The Soviet army was capable of maintaining its control over the territory it had occupied, but it had no means to enforce its acquisition against the clearly demonstrated will of the Western Allies. Evidence of this may be found in Stalin's May 1946 statement to a narrow circle of Soviet and Polish leaders: 'In my opinion, no war is now possible. Neither we nor the English and Americans can start a war. Everyone is sick of it. Nor do we have any objective for starting a war. We are not planning to invade England or America, and they will not risk it. No war is possible for at least twenty years. ${ }^{379}$ This was no smoke screen. The USSR was hardly capable of any serious conflict at that point. During the war, up to 34.5 million people were in the Soviet army, many of whom did not return or were not capable of another military deployment. After the war, the USSR demobilized its army and reduced troop numbers from 11 million in 1945 to 3 million by the late 1940s. ${ }^{380}$ The scope of its wartime loss made it difficult for the USSR to maintain an enormous army. Population depletion left the Soviets wanting for recruits, and this is aside from the superior quality of the Western Allies' military technology and their progress in developing nuclear weapons and carriers. In February 1946, during the first post-war

378 They included the opening of the Black Sea straits to Soviet ships, modification of the eastern Soviet-Turkish border, and reinforcing the autonomy of Iranian Azerbaijan. Stalin indicated to Roosevelt his wish to acquire Libyan territory under his administration and made use of the Soviet obligation to enter the war with Japan to enforce his sovereignty over southern Sakhalin and the Kurile, as well as the restoration of Soviet participation in the administration of the Chinese Eastern Railway in Manchuria.

379 See Vostochnaya Evropa v dokumentakh rossiiskikh arkhivov, 1944-1948 gg. Vol. I, (Moscow/ Novosibirsk: Sibirskiy chronograph, 1997), pp. 456-457.

380 Rossiya i SSSR v voynah XX veka, pp. 245-246, also, Stalinovy války, Roberts G.: Stalin's War), p. 433. 
elections in the USSR, Stalin 'optimistically' reassured the electorate that within three or more five-year plans-fifteen years or more-he would be capable of handling 'all eventualities', by which he meant armed conflicts and wars. ${ }^{381}$

Crucial is that these disagreements did not find resolution, but rather festered and came to a head. In early 1947, Truman appointed George C. Marshall Secretary of State, and he shifted American post-war politics in a new direction, abandoning the existing effort to create a common Allied policy in Germany and Europe, with the result that Europe and later Asia were divided into two antagonistic camps. This shift allowed for more rapid consolidation of the economic and political situation in Western Europe and West Germany. But in Eastern Europe, it strengthened the Stalinist regime, led to the elimination of any vestiges of pluralism and altered the social atmosphere. Contact with the Allies became a 'subversive', 'hostile' act.

But we do not wish to launch off on a theme to do with the post-war development of the USSR and its zone of interest. Soviet politics was frequently repugnant to the Western Allies and to their representatives in Moscow. With the hindsight of several decades, we may claim that the frequent worries of the Allies greatly exaggerated. The main issue faced by Western Europe and the USA was not so much the threat of Soviet expansion, but the instability present in a number of key European and Asian countries.

Even here, however, there is no need to conceive an 'alternative' solution for that time period. This lies outside the objective and the potential of historiography. The past cannot be changed retrospectively; historians may not succumb to the ambition to advise politicians what to do in a similar situation. The decision taken to shift American politics and to declare the Marshall Plan was not made simply upon the basis of the existing situation in Europe; it also reflected the internal political situation in the United States. Its result was gradual stabilization of the social and political situation in the countries of Western Europe, but for the countries of Central Europe and the Balkans, there were no immediate benefits. For the USSR, it was a call to pursue a radical course of socialism that ended up separating the European West from the European East for decades.

381 See Stalin I. V. Rech na predvybornom sobranii izbirateley stalinskogo izbiratelnogo okruga Moskvy, 9. fevrala 1946 g., p. 22. 


\section{A Few Words in Conclusion}

In recent decades, a number of studies and reflections have been published that compare the social and political systems of Stalin's USSR and Nazi Germany. But this research direction should not overlook their substantial differences-differences in their economic and social bases, in their ideologies, objectives, and the real-world tasks that occupied them or that they wished to address. These pages have attempted to capture the development of the USSR from 1917 until 1945 in great detail, with a focus on the development of post-war. These pages have attempted to detail the development of the USSR from 1917 until 1945, weaving into the story the impact of Germany's post-war development and the rise of the Nazi regime, itself the subject of an extensive global literature. While we do not wish to supplant that literature, we would wish to add a few words on the topic. The deep differences in starting conditions between Germany and Russia after World War I, both as regards economic and cultural development and as regards the level of civilization present and the standard of living, need little discussion. They are self-evident.

It must be acknowledged that during the interwar period the USSR was able to create the governmental, political, and economic basis to survive. But this came at the price of unimaginable sacrifice that impacted all levels of society, particularly peasants and the urban lower class because of the living conditions they had to endure. What was created, however, was not in keeping with the basic promise made by the Russian revolution to create a new, socially just, humane society. Despite this, it must be noted that the Soviet state, in contrast to Hitler's Germany, did not target external expansion, the creation of an empire, but was forced to focus instead on its own internal issues.

We have already noted that large-scale societal goals may be realized only in exchange for a price paid by society. In the Soviets' case, our revulsion at what transpired stems not from the fact that this price was disproportionately high and the backwardness of pre-revolutionary Russia vast. It was that the price exacted was set not just by the limited capabilities of the new upper stratum, but by the moral and instinctual lack of its leading representatives.

When we compare the development of Stalin's USSR and Hitler's Germany, we must remember that both regimes were involved in a war, and it was one in which the USSR was not acting purely as a nation-state or empire, but rather as a member of the anti-Hitler coalition whose name was to protect positive human and social values. The country made a significant contribution to defeating Nazism 
and fascism in Europe. This coloured the impressions contemporaries to these events had of the Soviet Union, and that included leading politicians and members of the intelligentsia.

When we compare the Soviet and Nazi regimes and their leaders Stalin and Hitler, there can be no doubt about the similarities in many of their aspects. Both regimes arose from the consequences of World War I, both were dictatorships heading towards totalitarianism, both were characteristic of the utmost brutality in their methods of controlling the society, and their dishonour to human life. Nonetheless, there are still marked differences between them. They came into existence in different historical circumstances, they are based on dissimilar ideologies, and they focused on different social aims.

Something that also needs to be said is that the characteristics of Stalin's regime may not be arbitrarily applied to the Soviet regime in the post-Stalin era. A number of changes took place which transformed the regime's nature. These changes did not eliminate hegemony and imperialism, but they vitiated elements of the totalitarian and terrorist understanding of power. It must be acknowledged that from the 1960s through the 1980s, the Soviet Union played a model role, particularly in several developing countries. Whether that role was positive or negative is an open question whose answer may come with the further development.

Very significant was also the nationwide effort that succeeded in overcoming the vast losses of the early phase of war. However, this is when the complete insufficiency of the Soviet economy and social system manifested themselves. Similarly to the weight of the early "socialist construction" which brought the USSR in early stages of the war to the verge of collapse, the USSR could not manage the weight of becoming a superpower: its economic and social systems lost their dynamics, fossilised and fell into degeneration.

The USSR, unlike Hitler's Germany, did not pass out of existence because of a war against democratic states. Its rulers lost touch with the younger politically active generations of their own population. These generations abandoned the regime and its dogmata, this estrangement resulted in fundamental changes of the political and social life. The ultimate result was the 1991 disintegration of the USSR and its social foundations. This development has not yet come to an end, nor is it possible to see whence it ultimately leads. 


\section{Резюме}

Предметом данной работы является превращение России из отстающей европейской державы начала XX века в великую державу. Оно явилось следствием глубоких перемен в Европе, вызванных результатами двух мировых войн и изменениями в соотношении сил в мире. В работе пересматриваются построения прежней советской историографии, как и наслоения историографии периода «холодной войны». Революция 1917 г. так представляется следствием неблагоприятного для России хода первой мировой войны, приведшего к разрушению традиционного строя и порядка ее жизни. Она не стала «гражданской», поскольку гражданские слои общества в России не были достаточно сильны, организованы и опытны, чтобы направлять ее развитие. В то же время она не была и революцией «пролетарской» поскольку «пролетариат» оставался относительно небольшой частью населения. Власть оказалась в руках радикальной социалистической партии, опиравшейся на низы крупных городов, солдат и моряков, а также деревенскую бедноту. Для реализации положительных целей этой власти недоставало знаний и опыта, а ее программа, опиравшаяся на марксизм, не соответствовала уровню развития, как и актуальному состоянию страны, тяжело пострадавшей от мировой и гражданской войн. К тому-же Россия, а позднее СССР, оказались на долгие годы изолированными от внешнего мира, центров мирового хозяйства, что вело к их хозяйственной автаркии. Задачи восстановления и ускоренного развития экономики здесь решались за счет сохранения низкого уровня жизни, повышенной эксплоатации труда, а также перекачки средств из сельского хозяйства в промышленность. Это неизбежно вело к повышенной роли насилия в социальной и политической жизни страны и к непрерывно усиливающейся централизации власти.

Такое направление развития обостряло противоречия внутри правящей партии. Они не могли быть устранены, для этого ей не хватало не только эффективных идейных импульсов, но также материальных рессурсов. Внутрипартийные разногласия подавлялись, а с середины 30-х годов все больше становились объектом произвольного, истребительного террора. При обратном взгляде на их содержание приходится отметить, что именно рост роли насилия и массового террора, ставших «инструментами социалистического строительства» и сохранения 
«внупартийного единства» привел к превращению советского строя в строй тоталитарный.

«Успехи социалистического строительства» - индустриализация, сопровождавшаяся повсеместной коллективизацией и ликвидацией частного хозяйства - в этот период не означали возникновения нового, социально справедливого общественного строя, а ценой совершенно исключительных потерь и жертв, утраты многих миллионов человеческих жизней, привели к увеличению хозяйственного, прежде всего промышленного потенциала страны. В то же время рост ее образовательного и культурного уровня был значительно ослаблен уничтожением значительного слоя старой общественной элиты, как и элиты новой, выросшей в условиях СССР.

В последние годы появилось немало работ, которые приравнивали общественную и политическую систему СССР к системе нацистской Германии. При сравнении обоих систем мы находим в них ряд сходных явлений, что относится к способам и механизмам осуществления власти, роли террора и насилия, отношения к ценности человеческой жизни и ее достоинству. Тем не менее эти элементы сходства не должны заслонять от нас их существенных различий: Германия была экономически и культурно одной из ведущих стран европейского континента, Россия же была страной отстающей в экономическом, социальном и образовательном отношении. Нацистская Германия искала выход из проблем, возникших вследствие ее поражения в первой мировой войне, на путях реванша и территориальной экспансии, а ее идеологией после захвата власти нацистами стал рассизм и идеи мирового господства. В СССР речь в первую очередь шла, хотя и не исключительно, о воссоздании социально-экономической, общественной и госурарственной базы существования страны, призванной заменить полностью разрушенный строй и порядок жизни Российской империи. Одновременно в порядок дня встала и необходимость обеспечить быстрый рост и модернизацию производственной, социальной и культурной жизни страны, что господствовавшей властью тогда ошибочно отождествлялось с «построением социализма». Оба режима, как большевистский так и нацистский, отчетливо понимали свое отличие друг от друга и свою враждебность по отношению друг к другу. В этой связи можно вряд-ли недооценивать, что во второй мировой войне СССР, несмотря на большие потери, причиненные ему Сталиным и его системой власти, был одной из опор коалиции, победившей нацизм, и что это, несмотря на все различия 
строя СССР и строя его западных союзников, нельзя никак считать случайностью.

Данное исследование оставляет в стороне развитие СССР и России после второй мировой войны, которое является большой, самостоятельной темой. Тем не менее опыт подъема СССР в межвоенный период, его роль во второй мировой войне, как и ряд его общественно-политических идеалов оказали заметное влияние на развитие ряда стран послевоенного «третьего мира». В то же время в его послевоенном развитии долгое время сохранялись существенные элементы тоталитаризма, которые сегодня уходят в прошлое. Современная Россия существенно отличается от прежнего СССР, но это тема для отдельного, самостоятельного исследования. 



\section{Bibliography}

Abaturov V., Morozov M., Portugalsky P., Strashnaya tsena pobedy: Neizvestnyje tragedii Velikoy Otechestvennoy. Moscow, Yauza-EKSMO, 2010.

Barsenkov A. S./ Vdovin A. I., Istorija Rossii 1917-2004, Moscow, Aspekt-Press, 2006.

Bojko O./ Gonec V., Nejnovější dějiny Ukrajiny, Brno, Jota, 1997.

Bonwetsch B., Die russische Revolution 1917: Eine Sozialgeschichte von der Bauernbefreiung 1861 bis zum Oktoberumsturz, Darmstadt, Wissenschaftliche Buchgesellschaft, 1991.

Calvocoressi P./ Wint B., Total war: Causes and Courses of the Second World War, Pelican Books 1974.

Carr E. H., The bolshevik Revolution 1917-1923, Vol. I-III. Harmondsworth, Penguin Books, 1966.

Chubarjan A. O., Kimball W.F., Reynolds D. (eds.), Soyuzniki v voyne 1941-1945, Moscow, Nauka, 1995.

Churchill W. S., The Second World War, London, Cassel, 1966; Vol. IV, VI.

Československo-sovětské vztahy v diplomatických jednáních 1939-1945: Dokumenty, Vol. 2, červenec 1943-březen 1945, (ed.) J. Němeček et al. Prague, SÚA, 1999.

Daniels R.V., Das Gewissen der Revolution: Kommunistische Opposition in der Sowjetunion, Berlin, Olle und Wolter, 1978, p. 375.

Davies R. W., Soviet Economic Development from Lenin to Khrushchev, Cambridge, Cambridge Univ. Press 1998.

Davies R. - Danilov V., Dialog istorikov, in: Istoriya SSSR, 2/1990.

Deutscher Oktober 1923: Ein Revolutionsplan und sein Scheitern. Hrsg. B. H. Bayerlein, L. G. Babičenko, F. I. Firsov, A. JU. Vatlin. Berlin, Aufbau-Verlag 2003.

Dimitroff G., Tagebücher 1933-1943, (ed.) Bayerlein B., Berlin, Aufbau-Verlag, 2000.

Djilas M., Razgovory so Stalinym. Frankfurt/M. Posev 1970.

Erickson J., The Soviet High Command, a Military-Political History 1918-1941, London-Portland, Franc. Cass, 2001.

Furet F., Das Ende der Illusion: Kommunismus im 20. Jahrhundert. MünchenZürich, Piper, 1998.

Geller M. / Nekrich A., Utopia u vlasti, Istoria Sovetskogo Soyuza s 1917 goda do nashich dney: London, Overseas Publications Interchange Ltd. 1986. 
Geyer D., Der Russische Imperialismus: Studien über der Zusammenhang von innerer und auswertiger Politik. Göttingen,Vandenhoeck a. Ruprecht, 1977.

Gorodetsky G., Rokovoy samoobman: Stalin i napadenie Germanii na Sovetskii soyuz, Moscow, ROSSPEN, 2008.

Hildermeier M., Geschichte der Sowjetunion, 1917-1991: Entstehung und Niedergang des ersten sozialistischen Staates, München, C. H. Beck, 1998.

Istoriyu - v shkolu: sozdaniye pervych sovetskikh uchebnikov, Kudrjashov S. (ed.), Vestnik archiva Presidenta Rossiyskoy federatsii, Moscow 2008.

Ivnicky N. I., Golod 1932-1933 godov v SSSR, Moscow, Sobranie, 2009.

Kantor Yu., Zaklyataya druzhba: sekretnoye sotrudnichestvo SSSR i Germanii v 1920-1930-ye gody, St. Petersburg, Piter, 2009.

Kak lomali nep: stenogrammy plenumov CK VKP(b) 1928-1929 gg. v 5-ti tomach, (eds) Danilov V.P., Khleniuk O.V., Vatlin A.Ju., Moskva, Mezhdunar. Fond „Demokratiia“, 2000.

Khaustov V./Samuelson L., Stalin, NKVD i repressii, 1936-1938, Moscow, ROSSPEN, 2009.

Khlevniuk O., Chozyajin: Stalin i otverzhennye stalinskoy diktatury, Moscow, ROSSPEN 2010.

Khlevniuk O., Stalin i Ordzhonikidze: Konflikty v Politbyuro v 30-e gody, Moscow. Rossiya molodaya, 1993.

Kirilina A., Neizvestnyj Kirov, St. Petersburg/ Moscow, Neva/Olma-Press, 2001.

Knight A., Beria: Stalin's First Lieutenant, Princeton Univ. Press, 1995.

Kommunisticheskaya partia Sovietskogo Soyuza v rezolyutsyakh i resheniyakh s"ezdov, konferentsii i plenumov CK, I-III, Moscow, Gospolitizdat, 1953.

Kommunisticheskaya oppozitsiya, ed. Yuri Felshtinsky, Volume 1-4, Benson Ver., Chalidze Publ., 1988.

Korzhichina T. P., Izvol'te byt' blagonadezhny! Moscow, RGGU, 1997.

Kratkiy kurs istorii SSSR, (eds.) Shestakov A. V., Kudrjashov S. Moscow, Vestnik arkhiva Prezidenta Rossiyskoy federatsii, 2008.

Lebina N. B., Povsednevnaya zhizn sovietskogo goroda 1920-1930 gody. S. Peterburg, Letnij sad, 1999.

Litera B. a kol., Formování stalinského mocenského systému: K problematice tzv. sebedestrukce bolševiků 1928-1939, Prague, HIU ČAV, 2003.

Litera B., Historie Rudé armády 1917-1941, Praha, HU AVČR. 1997.

Litvin A./ Keep J., Stalinism: Russian and Western views at the turn of the Millenium, London/New York, Routledge/ Taylor \& Francis Group, 2005. 
Lubyanka: Stalin i Glavnoye upravleniye gosbezopasnosti NKVD 1937-1938, (eds.) Chaustov V. N. et al. Moscow, MFD, 2004.

Lubyanka: Stalin i VCK-GPU-OGPU-NKVD, janvar'1922-dekabr'1936, (eds.) V.N. Chaustov et al., Moscow, MFD, 2003.

Maslov S., Kolchoznaya Rossiya, w.p. (Prague?), Krestyanskaya Rossiya, 1937.

Materialy fevralsko-martovskogo plenuma CK VKP/b 1937 goda, in: Voprosy istorii No 10/94, pp. 13-27; No 11-12/94, pp. 3-29; No 2/95, pp. 3-26.

Meerovich M., Nakazaniye zhilishchem: Zhilishchnaya politika $v$ SSSR kak sredstvo upravleniya ljud'mi 1917-1937, Mosscow, ROSSPEN, 2008.

Meltyuchov M.I., Operaciya "Bagration" $i$ Varshavskoe vosstanie 1944 goda, in: Voprosy istorii 11/04.

Minakov S., Voyennaya elita 20s-30s godov XX veka, Moscow, Russkoye slovo, 2004.

Moskva i vostochnaya Evropa: Stanovlenie politicheskikh rezhimov sovietskogo tipa 1949-1953 (eds): T. V. Volokitina, G. P. Muraško, A. F. Noskova, T. A. Pokivajlova, Moscow: ROSSPEN 2002.

Nashe otiechestvo: opyt politicheskoy istorii, ed. S.V. Kuleshov. Volume 1-2, Moscow, Terra 1991.

Naseleniye Rossii v XX veke: Istoricheskiye Ocherki (ed. Ju. A. Polyakov), Moscow, ROSSPEN 2000, Vol. 1-2.

Nezhinsky L. N., V interesakh naroda ili vopreki im? Sovětskaja mezhdunarodnaya politika 1917-1933 godach, Moscow, Nauka, 2004.

NKVD I polskoje podpolje 1944-1945.(Po “osobym papkam” I. V. Stalina), (ed.) Noskova. A. F., Moscow, Institut slavianovedenia i balkanistiki AN RF, 1994.

Organizatsionnaia struktura Kominterna. 1919-1943. (eds.) Adibekov, G.M./ Shakhnazarova, E.N./ Shirinia K. K. Moscow, ROSSPEN 1997.

Paczkowski A., Půl století dějin Polska 1939-1989 (from Polish: Pół wieku dziejów Polski 1939-1989), Prague Academia, 2000.

Pavlyuchenkov S. A., Krestyansky Brest, Moscow, Russkoe knigoizd. tov. 1996.

Pavlyuchenkov S.A., Orden mechenoscev, Partiya i vlast' posle revolyucii 19171929 gg., Moscow, Sobranie, 2008.

Pechatnov V. O., (Stalin, Ruzvelt (Roosevelt), Truman: SSSR i SSA v 1940-ch gg., Moscow, Terra, 2006).

Pechenkin A. A., Voyennaya elita v 1935-1939 gg.: Repressii i obnovlenie, Moscow, VZFEI, 2003.

Perepiska Predsedatelya Sovieta Ministrov SSSR I. V. Stalina s Prezidentami SSA i Prem'jer Ministrami Velikobritanii vo vremya Velikoy Otechestvennoy voyny 1941-1945 gg., Moscow, 1986. 
Plechanov A., Dzerzhinsky: The First Chekist of Russia. Moscow, Olma Media Grupp, 2007.

Rauch G. von, Geschichte des bolschewistischen Russlands, Frankfurt/ M, Rheinische Verlagsanstalt, 1963 (Geschichte d. Sowjetunion, Stuttgart, Kröner, 1977).

Reabilitatsiya: Kak eto bylo. Dokumenty Priezidiuma CK KPSS i drugiye matierialy, (eds.) A. N. Jakovliev, Volume 1, Moscow, MFD, 2000-2003, Vol. I-III.

Reiman M., Lenin, Stalin, Gorbachev: Kontinuität und Brüche in der sowjetischen Geschichte, Hamburg, Junius, 1987.

Reiman M., The Birth of Stalinism: The USSR on the Eve of the "Second Revolution", Bloomington Ind., Indiana Univ. Press, 1987.

Reiman M., ve spolupráci s Bohuslavem Literou, Karlem Svobodou a Danielou Kolenovskou: Zrod velmoci: dějiny Sovětského Svazu 1917-1945, Praha, Karolinum, 2013.

Roberts G., Stalin's War: From World War to Cold War, 1939-1953, Yale Univ. Press, 2008.

Rossia i SSSR v voynach XX. vieka, poteri vooruzhennykh sil: Statisticheskoye issledovanie, G. F. Krivosheyev (ed.). Moscow, Olma-Press, 2001.

Rzheshevsky O.A., Stalin i Cherchil' (Churchill): Vstrechi, Besedy, Diskussii: Dokumenty, kommentarii 1941-1945, Moscow, Nauka, 2004.

„Schastie literatury”: gosudarstvo i pisateli, 1925-1938: Dokumenty, Babičenko D. L. (Ed.) Moskva, ROSSPEN, 1997.

Sovietskii faktor v Vostochnoy Evrope 1944-1953: Dokumenty, (eds.), Volokitina T. V. and Oth., Moskva, Vol. 1,2, ROSSPEN 1999.

Sovietskoye obshchestvo: vozniknoveniye i razvitiye, istoricheskiy final, (ed.) Ju. N. Afanasjev, Moscow, RGGU, 1997.

SSSR i germanskiy vopros 1941-1949: Documents AVP RF, (eds.) Kynin G. P. Laufer J., Moscow, Mezhdunarodnyye otnosheniya, 1996.

Stalin i powstanie Warszawskie, ed. A. Przygoński, Warszawa, Gražyna, 1994.

Stalin I. V., O Velikoy Otechestvennoy voyne Sovetskogo Soyuza, Moscow: OGIZ, $5^{\text {th }}$ ed., 1946.

Stalin I. V., Rech na predvybornom sobranii izbirateley stalinskogo izbiratel'nogo okruga Moskvy, 9. fevrala $1946 \mathrm{~g}$.

Stalin I., Sochinenia, Gospolitizdat, 1947-1951, Volume: 10, 11, 12, 13.

Stalinizm v sovietskoy provincii 1937-1938 gg.: Massovaya operatsia na osnove prikaza No 00447, (eds.) Junge M., Bonwetsch B., Moscow, ROSSPEN, 2009.

Stalinskoye Politbyuro v 30-e gody, (eds.) O. V. Khlevniuk et al. Moscow, AIRO-XX, 1995. 
Stenogrammy zasedaniy Politbyuro CK RKP/b-VKP/b, Vol. I, Anderson K.M. (ed.), Moscow, ROSSPEN, 2007.

Suvorov V., Ledokhod: kto nachal vtoruyu mirovuyu voynu, Moscow, Novoye vremya, 1992.

Suvorov V., Den - M, kogda nachalas' vtoraya mirovaya voyna, Moscow, Vse dlya vas, 1994.

Tainy natsionalnoy politiki CK RKP: Stenograficheskiy otchet IV. soveshchaniya CK RKP, 1923 Moscow, Insan, 1992.

Teheran, Yalta, Potsdam: Die sowjetischen Protokolle von den Kriegsderonferenzen der „Grossen Drei“, (ed.) Fischer A., Köln, Verlag Wissenschaft und Politik, 1985.

Trotsky L.D., K socializmu ili k kapitalizmu, Moscow-Leningrad, Planovoye khozyajstvo, 1926.

Trotsky L. D., Prestuplenia Stalina, Moscow, Izdat. Gumanitarnoy literatury, 1994.

Utkin A., Vtoraya mirovaya voyna, Moscow, Algoritm, 2002.

Vert N. (Nicolas Wert), Terror i besporyadok: Stalinizm kak sistema, Moscow, ROSSPEN, 2010 (translated from the French - Wert Nicolas, La Terreur et le Déssarroi: Staline et son systeme).

Vdovin A.I./Zorin V. Ju. / Nikonov A. V., Russkiy narod $v$ natsionalnoy politike, XX vek, Moscow, Russkiy mir, 1998.

Voyennaya razvedka informiruyet: Dokumenty Razvedupravlenia Krasnoy Armii. Janvar' 1939-1941, Gavrilov V. (ed.), Moscow, MDF, 2008.

Voyenny soviet pri narodnom komisare oborony SSSR, 1.-4. iyunya 1937 g.: Dokumenty i materialy, Moscow, ROSSPEN, 2008.

Vos'moy s'yezd RKP/b: Protocols, Moscow, Gospolitizdat, 1959.

Vostochnaya Evropa v dokumentakh rossiiskikh arkhivov, (ed.) T.V. Volokitina et al., Vol. 1, Novosibirsk, Sibirskiy khronograf, 1997.

Zubkova Ye., Pribaltika i Kreml' 1940-1953, Moscow, ROSSPEN, 2008.

Zemskov V. N., Spetsposelentsy v SSSR 1930-1960, Moscow, Nauka, 2005.

Zhukov Yu., Inoy Stalin: Politicheskiye reformy v SSSR b 1933-1937 gg. Moscow, Vagrius, 2003.

Zubov A. B., Istoriya Rossii: XX vek. 1939-2007, Mocow Astrel'/ AST, 2000. 



\section{Index}

A

Alexander, king of Jugoslavia 96

Alliluyeva, Nadezhda S. 82

Avel 101

B

Barthou, Jean, 96

Beneš, Edvard. 152

Beria, Lavrentiy P. 110, 119

Berling, Zygmunt. 156

Blum, Leon. 97

Budionny, Semion M.

Bukharin, Nikolay I. 29, 33, 35, 36, $42-48$

C

Chiang, Kai-shek 53, 148

Chernov, Mikhail A. 105

Chicherin, Georgy V. 54

Chubar, Vlas 118

Churchill, Winston S. 123, 137-147, $149,154,157-164,167-169,171$

Cuno, Wilhelm 33

D

Davies, Joseph 142

Dzerzhinsky, Felix E. 44, 95

E

Eden, Anthony 139, 143, 149

Eideman, Avgust 114

Eiche, Robert I. 118

Eysmont, Nikolay B. 82

F

Feldman, Boris M. 114

Frumkin, Moisey I. 68
G

Gaulle, Charles de. 147, 148

Geyer, Dietrich 13

George, Lloyd David 72

Gorky, Maxim 105

H

Halifax, Edward F. 117

Herriot, Edouard 41, 72

Hess, Rudolf 123

Hitler, Adolf 95, 97-99, 113, 115, $117,118,121-123,127-129,134$, $135,137,138,141,143,149,150$, $153,154,160,168-170,172,177$, 178

Hopkins, Harry L. 137

J

Jagoda, Genrih G. 95

L

Litvinov, Maxim M. 100, 120, 147, 151,152

Lominadze, Vissarion V. 81

M

MacDonald, James Ramsey 41, 53, 72

Maisky, Ivan M. 141, 142, 147, 149-153, 170

Malenkov, Georgi M. 119, 125

Marshall, George C. 176

Marx, Karl 44, 45

Maslov, Sergey S. 61, 62, 93

Menzhinsky, Vyacheslav R. 95, 100

Meretskov, Kirill A. 127

Mikolajczyk, Stanislaw. 154-157 
Molotov, Vyacheslav M. 22, 48, 54, $63,64,67,73,81,83,84,92,100$, $101,103,121-123,125,139,140$, $156,158,166$

$\mathbf{N}$

Nikolayev, Leonid 93, 94

O

Ordzhonikidze, Grigori (Sergo)

K. $31,104,105,115$

$\mathbf{P}$

Pavlov, Dmitri G. 58, 127

Paulus, Friedrich 134

Pechenkin, Alexandr A. 108, 113, 114, 127

Preobrazensky, Yevgeni 63

Pyotr I.

Pyatakov, Georgy L. 36, 39, 105

$\mathbf{R}$

Radek, Karl B. 33, 36, 105

Rakovsky, Christian G. 33, 41, 54, 60, 89, 105

Ribbentrop, Joachim v. 121, 122

Roberts, Geoffrey. 128, 138, 141, 145, $152,156,157,159,167,168,175$

Rjutin, Martemyan N. 81

Roosevelt, Franklin D. 96, 137-142, 144-147, 150, 154, 155, 157, 159, $160,162-165,168,169,171,175$

Rosengolts, Arkadi P. 105

Rudzutak, Jänis E. 118

Rykov, Alexey I. 19, 36, 41-44, 46-52, 62-69, 71, 73, 74, 80, 81, $83,100,105$

$S$

Sedov, Lev L. 60

Shvernik, Nikolay M. 94, 107, 110

Serebryakov, Leonid P. 105
Simonov, Konstantin. 115

Sikorsly, Wladyslaw. 143

Smirnov, Alexandr P. 82

Smirnov, Ivan N. 82, 104

Smuts, Jan Christian. 159

Sokolnikov, Grigory Ya. 69, 105

Standley, William H. 142

Stalin, Iosif V. 7, 8, 10-12, 22, 28, 31-39, 41-57, 59, 61-77, 79-89, 91-111, 113-130, 132, 133, 137150, 152-164, 167-173, 175-178

Stolypin, Petr A. 15

\section{T}

Timoshenko, Semion K. 123, 126, 127

Tito (Broz), Joseph 153, 154, 162, 168,171

Tolmachev, Vladimir N. 82

Tomsky, Mikhail P. 28, 36, 42, 51, 64, 67-69

Trotsky, Lev O. 10, 14, 27-36, $38-47,50,55,58-60,64,83,89$, $102-104,108,120$

Truman, Harry. 138, 164, 165, 174, 176

U

Uborevich Iyeronim P. 114

Uglanov, Nikolay A. 67, 68

V

Vasilevski, Alexandr M. 115, 126

Vatutin, Nikolay F. 126

Voroshilov, Klementy Ye. 100, 101, $105,108,113,114,125,126$

Y

Yakir, Iona E. 114

Yaroslavsky, Yemelyan 59

Yezhov, Nikolay I. 95, 100, 103, 105-107, 109, 110, 114, 119, 120 
$\mathbf{Z}$

Zinoviev, Grigoriy E. 19, 28, 31-36,

$38,39,41,42,44,46-48,50,51,55$,

$59,69,74,83,89,94,103,104$
Zhdanov, Andrey A. 83, 84, 101, 103

Zhukov, Georgi K. 126, 130

Zubkova, Yelena. 153 
